SERGIO KEMPENICH

\title{
PRÁTICAS DE PRODUÇÃO ENXUTA NO CONTEXTO DA CONSTRUÇÃO E MANUTENÇÃO DE REDES DE DISTRIBUIÇÃO DE UTILIDADES
}

Dissertação apresentada à Escola Politécnica da Universidade de São Paulo para obtenção do título de Mestre em Engenharia

São Paulo 
SERGIO KEMPENICH

\section{PRÁTICAS DA PRODUÇÃO ENXUTA NO CONTEXTO DA CONSTRUÇÃO E MANUTENÇÃ̃O DE REDES DE DISTRIBUIÇÃO DE UTILIDADES}

Dissertação apresentada à Escola Politécnica da Universidade de São Paulo para obtenção do título de Mestre em Engenharia

Área de Concentração:

Engenharia de Produção

Orientador: Prof. Dr. Dario Ikuo Miyake

São Paulo 


\section{DEDICATÓRIA}

Dedico este trabalho à minha querida esposa Betina, que é o grande amor da minha vida, e a todos os filhos que ainda teremos juntos. 


\section{AGRADECIMENTOS}

Ao Prof. Dr. Dario Ikuo Miyake, pela inigualável contribuição ao desenvolvimento deste trabalho, um excelente exemplo de orientador.

Aos Professores Alvair Silveira Torres Junior e Paulino Graciano Francischini, pelas inestimáveis recomendações fornecidas durante a etapa de qualificação.

Aos demais professores, funcionários e colegas do Departamento de Engenharia de Produção da Escola Politécnica que de alguma forma auxiliaram na conclusão deste trabalho.

Aos colegas da Comgás, pelo companheirismo no dia-a-dia e pela compreensão nos meus momentos de ausência.

Aos profissionais das empresas incluídas no estudo, pela receptividade e pelas informações fornecidas nas entrevistas.

A toda minha família e amigos, pelo incentivo e pela união durante os três anos de dedicação a este trabalho. Em especial, à minha querida esposa Betina, eterna companheira para todos os momentos.

Aos meus queridos pais Geraldo e Silvia, de quem tenho saudades, pela educação e pelos exemplos de vida que sempre nortearam meu caminho.

E finalmente, ao ETERNO, bendito seja, que nos conservou em vida, nos amparou e nos fez chegar a este momento. 


\section{RESUMO}

Esta dissertação considera a atuação das empresas responsáveis pelas redes de distribuição de água, energia elétrica e gás natural - denominadas "Redes de Distribuição de Utilidades" (RDUs) - como sistemas produtivos, com o propósito de conhecer e avaliar a maneira como os esforços de melhoria da produtividade são conduzidos em busca de metas como maior qualidade, menor custo e menor prazo de entrega ao cliente. Este estudo é desenvolvido tomando-se como referência o modelo da produção enxuta, desenvolvido pela Toyota Motor Company do Japão, fundamentado no princípio de buscar o aumento da produtividade por meio da identificação e eliminação de desperdícios. Embora originalmente disseminada na cadeia da indústria automobilística, a adoção e adaptação da abordagem de melhoria de processos deste modelo têm sido consideradas em diferentes setores. Assim, o presente trabalho tem como motivação explorar as possibilidades de estender a aplicação de conceitos e práticas da produção enxuta em empresas de RDU. Primeiramente, a cadeia de valor das RDUs é analisada, e são escolhidos dois processos - construção e manutenção - para o desenvolvimento do estudo. Em seguida, é apresentada uma revisão bibliográfica, a partir da qual um conjunto de dezenove "práticas enxutas" possivelmente aplicáveis aos processos escolhidos é identificado. Por meio de três estudos de caso, analisa-se em que medida as empresas responsáveis pelas RDUs aplicam tais práticas enxutas em seus processos, e em que medida a aplicação atual - ou uma possível aplicação futura de cada prática enxuta é motivada pelo pensamento enxuto. Com base nos dados levantados na pesquisa de campo, as práticas consideradas são avaliadas quanto ao potencial de efetiva aplicação em cada processo, levando-se em conta o objetivo de eliminação de desperdício. O estudo possibilitou verificar que todas as dezenove práticas são aplicáveis a pelo menos um dos processos considerados, sendo a maioria aplicável a ambos.

Palavras-chave: Redes de distribuição. Utilidades. Produção enxuta. Construção enxuta. Indústrias de processo contínuo. 


\begin{abstract}
This dissertation considers the performance of the companies that are responsible for water, electricity and natural gas networks - named "Utility Distribution Networks" (UDN) - as productive systems, in order to understand and evaluate the way that the efforts for continuous productivity improvement of their processes are conducted in search of goals such as more quality, less cost and less lead time to customer. The model that is used as a reference for this study is the lean production model, which was developed by the Toyota Motor Company in Japan, founded on the principle of search for productivity increase by the elimination on waste. Although it was originally disseminated in the auto industry value chain, the process improvement approach from this model has been considered in different industries. Therefore, the present work is motivated by the chance to explore the possibility of extending the lean production application concepts and practices to UDN companies. Firstly, UDN's value stream is analyzed, and two processes are chosen - construction and maintenance - for the development of study. Then, a bibliographic review is presented, from which a set of nineteen "lean practices" that maybe possibly applicable on the chosen processes is identified. By the development of three case studies, an evaluation is performed with the objective to analyze to what extent the companies that are responsible for UDN apply those lean practices on their processes, and to what extent the current application - or a possible future application - of each lean practice is motivated by lean thinking. Based on the data from the field research, the potential for effective application of the considered practices is evaluated for each process, taking into consideration the objective of elimination of waste. The study made it possible to verify that all the nineteen practices are applicable at least on one of the considered processes, and the majority is applicable on both processes.
\end{abstract}

Keywords: Distribution networks. Utilities. Lean production. Lean construction. Continuous process industries. 


\section{LISTA DE FIGURAS}

Figura 1-1 - Evolução no consumo setorial de energia elétrica (GWh) no Brasil entre 1971 e 2003, segundo classes de consumo (BRASIL, 2007)

Figura 1-2 - Evolução do balanço do gás natural no Brasil - 1996-2005 (BRASIL, 2006)

Figura 1-3 - Diferentes soluções para o monopólio (adaptada de GÓMEZ-IBÁÑEZ,

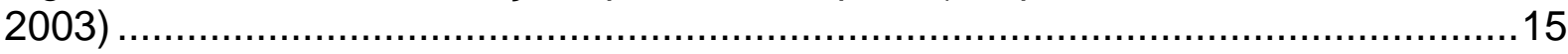

Figura 2-1 - O grupo das utilidades e os serviços em geral ................................20

Figura 2-2 - O grupo das Redes de Utilidades ..................................................21

Figura 2-3 - Preço da água por tipo de provedor de serviço, em US\$ por metro

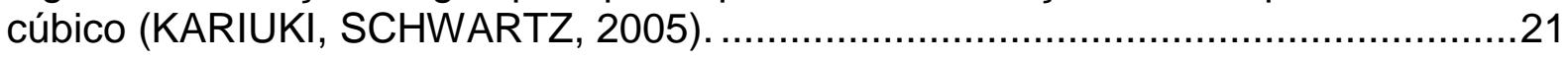

Figura 2-4 - Serviços de distribuição de água, gás e energia elétrica .......................22

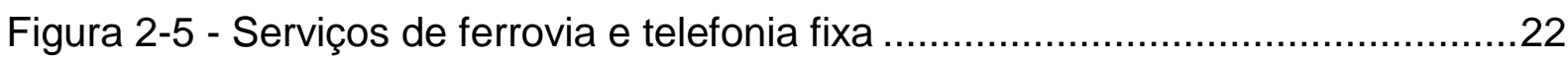

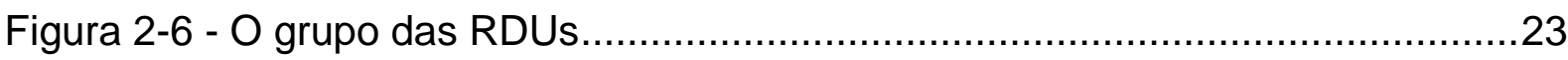

Figura 2-7 - A cadeia de suprimento da água. Fonte: SABESP (www.sabesp.com.br, acesso em 15/10/2008) ................................................................................24

Figura 2-8 - A cadeia de suprimento do sistema elétrico. Adaptada de Leão (2008)

Figura 2-9 - O fluxo do gás natural. Adaptada de Lexecon (2006) .........................26

Figura 2-10 - As RDUs nas cadeias de suprimento da água, energia elétrica e gás

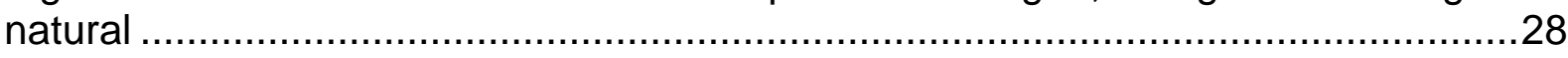

Figura 2-11 - Os fluxos na manufatura (baseada em PICCHI, 2001, p. 7) …...........30

Figura 2-12 - Fluxos da construção no contexto de uma RDU (baseada em PICCHI,

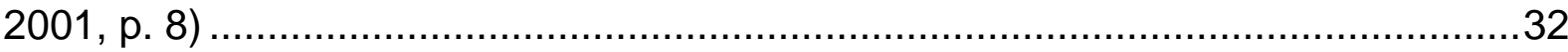

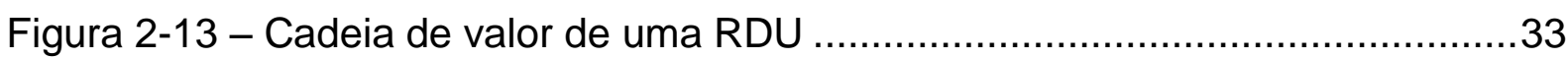

Figura 2-14 - O escopo da dissertação na cadeia de valor da RDU.........................35

Figura 2-15 - As sete pré-condições típicas de uma tarefa de construção (BERTELSEN et al, 2007)

Figura 2-16 - O fluxo da manufatura e o fluxo da construção (baseada em PICCHI, 2001).....

Figura 2-17 - Competição por recursos entre projetos (baseada em BERTELSEN;

SACKS, 2007).....

Figura 2-18 - Tipologia unidimensional para indústrias de processo (FRANSOO;

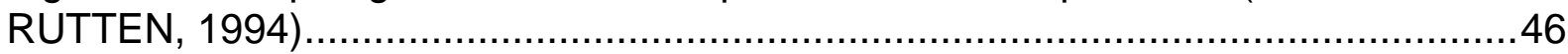

Figura 3-1 - O Modelo da Casa da Produção Enxuta (adaptada de DENNIS, 2008, p. 37) .51

Figura 3-2 - Muri, mura e muda (LEI, 2003, p. 53) …......................................55

Figura 3-3 - Exemplo de sistema andon em uma linha de montagem manual (LIKER, 2005, p. 138)

Figura 3-4 - Processos de Desenvolvimento de Produto Tradicionais Baseados em Pontos (SOBEK II; WARD; LIKER, 1999, p. 69) 
Figura 3-5 - Exemplo de SBCE (SOBEK II; WARD; LIKER, 1999) .........................66

Figura 3-6 - O sistema tradicional de empurrar (adaptada de BALLARD, 2000) ......68

Figura 3-7 - A elaboração de ordens de serviço no Last Planner (adaptada de

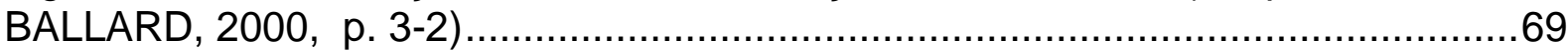

Figura 3-8 - O processo de Lookahead (adaptada de BALLARD, 2000, p. 3-10) .....70 Figura 3-9 - O Sistema Last Planner completo (adaptada de BALLARD, 2000, p. 36)

Figura 3-10 - Guia geral para aplicação de práticas enxutas em indústrias de processo (baseada em ABDUMALEK; RAJGOPAL; NEEDY, 2006, p. 23) …..........74

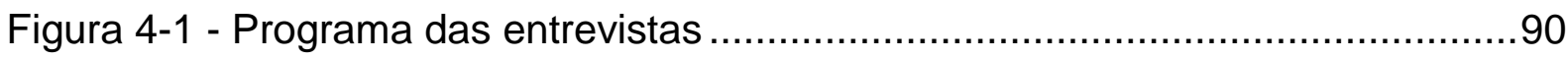

Figura 4-2 - Escala do Grau de Aplicação Geral (GAG).......................................95

Figura 4-3 - Escala do Grau de Relação Geral (GRG) .......................................95

Figura 5-1 - Detalhe do formulário de inspeção de obra da Empresa A, mostrando a

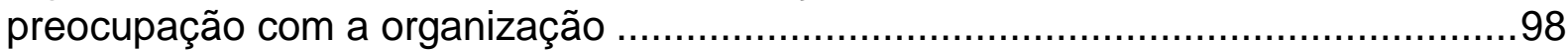

Figura 5-2 - Fusível mecânico para tração de tubulação (DANIELETTO, 2007, p.

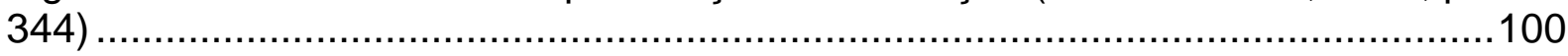

Figura 5-3 - Solda por eletrofusão (DANIELETTO, 2007, p. 264) ….....................101

Figura 5-4 - Equipamentos básicos de construção de redes de água - compressor, retroescavadeira, bate-estacas e cortador de solo............................................114

Figura 5-5 - Divisão das tarefas de manutenção entre equipes na Empresa B ......120 Figura 5-6 - Centro de Controle Operacional da Empresa B (material disponibilizado

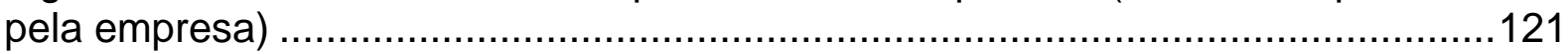

Figura 5-7 - Uso do Identificador de Cabos $\mathrm{Cl}$ (material disponibilizado pela Empresa C) 128

Figura 5-8 - Slide da apresentação sobre o Programa de Excelência no

Desempenho da Empresa C (material fornecido pela empresa; nomes omitidos para preservar sua identidade).

Figura 5-9 - Câmara transformadora da rede de distribuição subterrânea de energia elétrica (adaptada de material fornecido pela Empresa C).

Figura 6-1 - Práticas enxutas conforme Grau de Aplicação Geral (GAG) no processo de construção 143

Figura 6-2 - Práticas enxutas conforme Grau de Aplicação Geral (GAG) no processo de manutenção 149

Figura 6-3 - Graus de Aplicação Gerais (GAGs) das práticas enxutas nos processos de construção e de manutenção 153

Figura 6-4 - Práticas enxutas conforme Grau de Relação Geral (GRG) no processo de construção. 158

Figura 6-5 - Práticas enxutas conforme Grau de Relação Geral (GRG) no processo de manutenção.

Figura 6-6 - Comparativo entre os Graus de Relação Gerais (GRGs) das práticas enxutas nos processos de construção e de manutenção 162

Figura 6-7 - Aplicabilidade das práticas enxutas nos processos de construção e manutenção. 


\section{LISTA DE QUADROS}

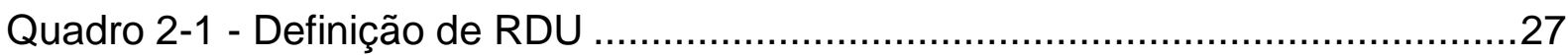

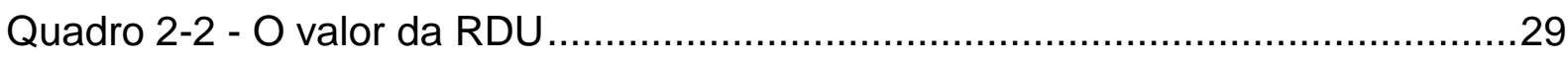

Quadro 2-3 - Características da construção e impacto na construção de uma RDU 43 Quadro 2-4 - Características de indústrias de processo contínuo e indústrias de processo por batelada (adaptado de FRANSOO; RUTTEN, 1994) ..........................47

Quadro 2-5 - Características do processo de manutenção de uma RDU

Quadro 3-1 - Sistemas e padrões coercivos versus sistemas e padrões habilitadores (ADLER, 1999 apud LIKER, 2005, p. 151) ..........................................................53

Quadro 3-2 - Seis grandes perdas que diminuem a eficiência das máquinas (adaptado de NAKAJIMA, 1989)

Quadro 3-3 - Exemplo de análise de restrições no Lookahead (VILLAS-BÔAS, 2004, p. 36) .71

Quadro 3-4 - Peculiaridades da construção e pilares do Last Planner...... .72

Quadro 3-5 - Práticas da produção enxuta, desperdícios e objetivos .78 Quadro 4-1 - Situações de aplicação das práticas enxutas em empresas de RDU .83 Quadro 4-2 - Características da pesquisa de caso e aplicação na presente dissertação

Quadro 4-3 - Formulário de tabulação dos dados das entrevistas .93

Quadro 5-1 - Processo de construção de redes de gás natural pela Empresa A .....97 Quadro 5-2 - Tabulação dos dados - Empresa A - Processo de construção ........104 Quadro 5-3 - Processo de manutenção de redes de gás natural pela Empresa A.105 Quadro 5-4 - Tabulação dos dados - Empresa A - Processo de manutenção ......110 Quadro 5-5 - Processo de construção de redes de água pela Empresa B............112 Quadro 5-6 - Tabulação dos dados - Empresa B - Processo de construção ........117 Quadro 5-7 - Processo de manutenção de redes de água pela Empresa B ...........118 Quadro 5-8 - Tabulação dos dados - Empresa B - Processo de manutenção ......124 Quadro 5-9 - Processo de construção de redes de energia elétrica pela Empresa C

Quadro 5-10 - Tabulação dos dados - Empresa C - Processo de construção ......133 Quadro 5-11 - Processo de manutenção de redes de energia elétrica pela Empresa C.

Quadro 5-12 - Tabulação dos dados - Empresa C - Processo de manutenção....140 Quadro 6-1 - Práticas enxutas conforme Grau de Aplicação no processo de construção...

Quadro 6-2 - Práticas enxutas conforme Grau de Aplicação no processo de manutenção.

Quadro 6-3 - Práticas enxutas conforme Grau de Relação no processo de construção

Quadro 6-4 - Práticas enxutas conforme Grau de Relação no processo de manutenção. 


\section{LISTA DE ABREVIATURAS E SIGLAS}

API: American Petroleum Institute

APICS: American Production and Inventory Control Society

Eletrobrás: Centrais Elétricas Brasileiras S/A

Eletronorte: Centrais Elétricas do Norte do Brasil S/A

GA: Grau de Aplicação

GAG: Grau de Aplicação Geral

GMP: Grupo de Melhoria de Processo

GR: Grau de Relação

GRG: Grau de Relação Geral

GPS: Global Positioning System

IGLC: International Group for Lean Construction

ISO: International Organization for Standardization

JIPM: Japan Institute of Plant Maintenance

JIT: Just-In-Time

MIT: Massachusetts Institute of Technology

OIT: Organização Internacional do Trabalho

PIB: Produto Interno Bruto

PPC: Percent Plan Complete

RCM: Reliability Centered Maintenance

RDU: Rede de Distribuição de Utilidade

ROIC: Return On Invested Capital

Sabesp: Companhia de Saneamento Básico do Estado de São Paulo

SAE: The Engineering Society For Advancing Mobility: Land, Sea, Air and Space

SBCE: Set-Based Concurrent Engineering

SMED: Single Minute Exchange of Dies

STP: Sistema Toyota de Produção

TPEM: Total Productive Equipment Management

TPM: Total Productive Maintenance

TPM-AM: Autonomous Maintenance

TPM-EM: Equipment Management/Improvement

TPM-PM: Preventive/Predictive Maintenance

WIP: Work-In-Progress 


\section{SUMÁRIO}

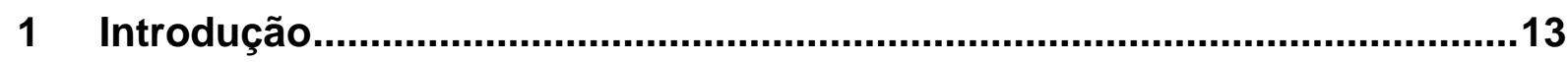

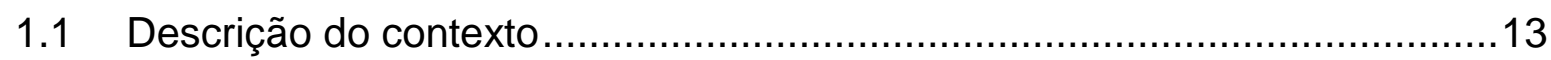

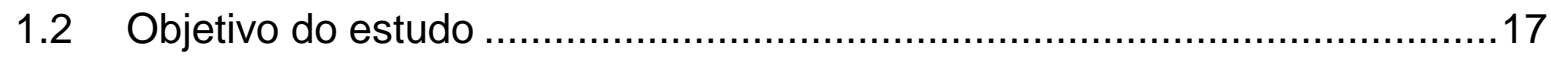

2 As Redes de Distribuição de Utilidades (RDUs)...........................................19

2.1 Posicionamento das RDUs entre os setores de serviços ............................19

2.1.1 Primeiro corte: "Utilidades" ............................................................................... 19

2.1.2 Segundo corte: "Redes de Utilidades" ..................................................................... 20

2.1.3 Terceiro corte: "Redes de Distribuição de Utilidades"................................................. 22

2.2 Posicionamento das RDUs nas cadeias de fornecimento de água, energia

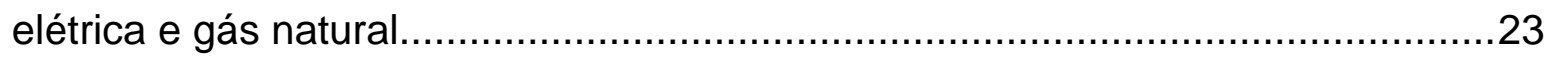

2.2.1 A cadeia de fornecimento da água ................................................................. 23

2.2.2 A cadeia de fornecimento da energia elétrica ........................................................... 25

2.2.3 A cadeia de fornecimento do gás natural..................................................................... 26

2.2.4 Posicionamento das RDUs nas cadeias apresentadas - a definição de RDU.............. 27

2.3 O processo produtivo de uma RDU.........................................................28

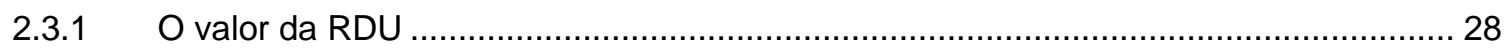

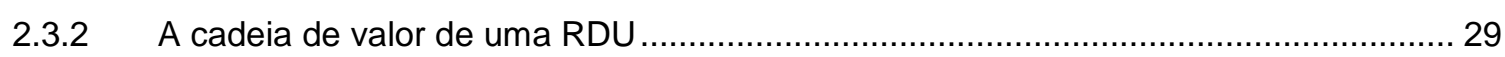

2.4 Os processos abordados na dissertação - construção e manutenção de RDU 33

2.4.1 Características do processo de construção de uma RDU ….......................................... 35

2.4.2 Características do processo de manutenção de uma RDU ......................................... 43

3 A produção enxuta e extensões de sua aplicação.........................................48

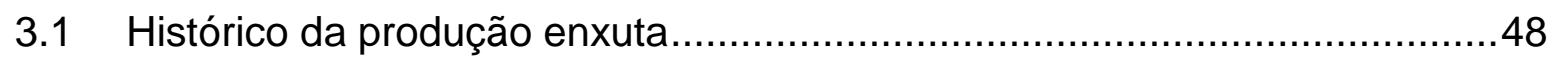

3.2 O pensamento enxuto e os principais elementos da produção enxuta ........49

3.2.1 Padronização e Estabilidade ............................................................................. 52

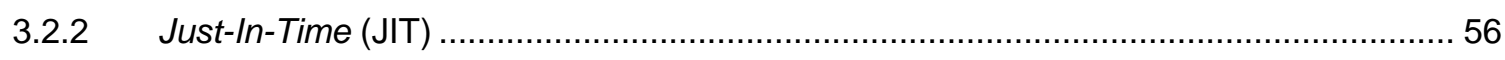

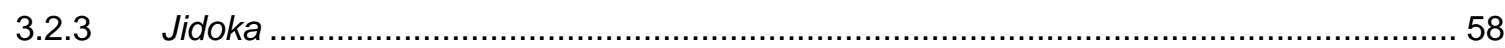

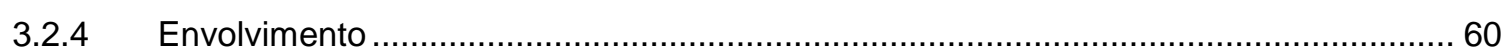

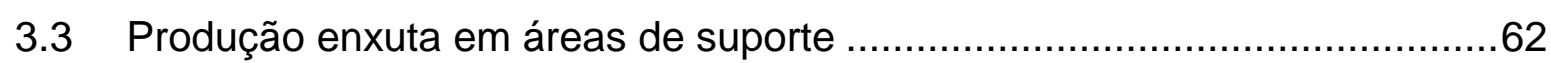

3.3.1 Produção enxuta na manutenção - o TPM e o TPEM..................................................... 63

3.3.2 Produção enxuta no desenvolvimento de novos produtos - o SBCE ………………..... 64

3.4 Produção enxuta em outros setores da economia ......................................67

3.4.1 Produção enxuta na construção civil - o Last Planner ..................................................... 67

3.4.2 Produção enxuta na indústria de processo contínuo ……………………………...... 73 
4 Metodologia de pesquisa

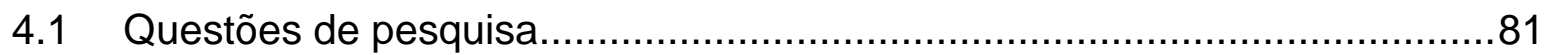

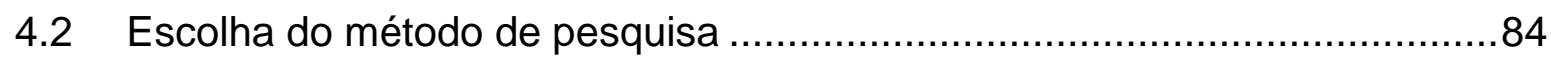

4.3 Considerações sobre o método de pesquisa escolhido - o Estudo de Caso 86

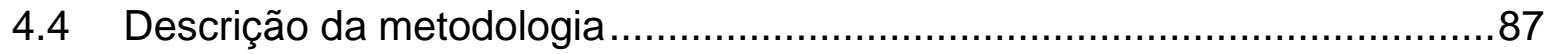

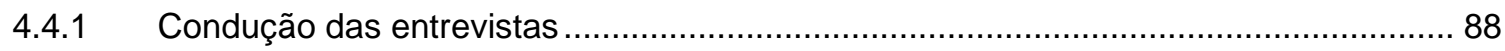

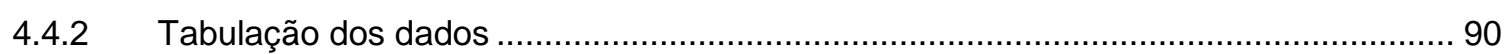

4.4.3 Compilação dos dados para análise .................................................................... 93

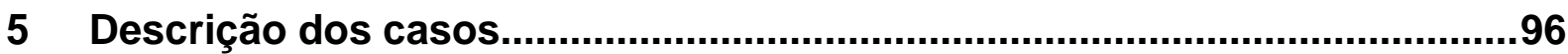

5.1 Empresa A - Distribuição de gás natural ................................................96

5.1.1 Processo de construção de redes de distribuição de gás natural ................................ 96

5.1.2 Processo de manutenção de rede de gás natural ...................................................... 104

5.2 Empresa B - Distribuição de água ...................................................111

5.2.1 Processo de construção de redes de distribuição de água ......................................... 111

5.2.2 Processo de manutenção de redes de distribuição de água ...................................... 117

5.3 Empresa C - Distribuição de energia elétrica ........................................124

5.3.1 Processo de construção de redes de distribuição de energia elétrica.......................... 125

5.3.2 Processo de manutenção de redes de distribuição de energia elétrica ...................... 133

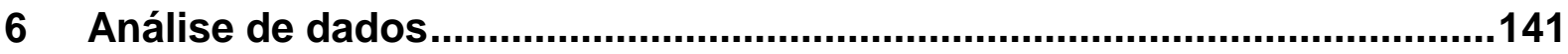

6.1 Grau de Aplicação de práticas enxutas em RDUs ..................................141

6.1.1 Grau de Aplicação de práticas enxutas no processo de construção .......................... 141

6.1.2 Grau de Aplicação de práticas enxutas no processo de manutenção .......................... 147

6.1.3 Análise comparativa entre os Graus de Aplicação ................................................ 153

6.2 Motivação para aplicação de práticas enxutas em RDUs .........................156

6.2.1 Grau de Relação de práticas enxutas no processo de construção ............................. 156

6.2.2 Grau de Relação de pratícas enxutas no processo de manutenção ............................ 159

6.2.3 Análise comparativa entre os Graus de Relação ………........................................ 162

6.3 Aplicabilidade das Práticas Enxutas em RDUs ....................................165

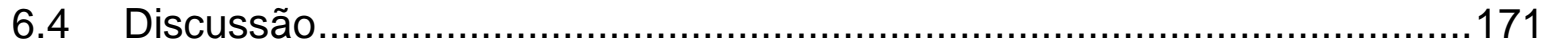

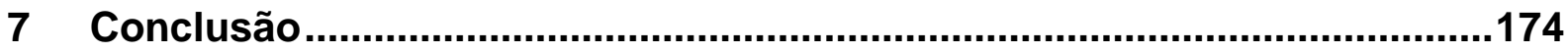

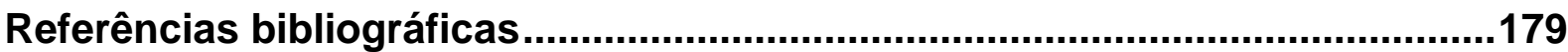




\section{Introdução}

\subsection{Descrição do contexto}

Os setores de distribuição de água, energia elétrica e gás natural representam uma pequena parcela no Produto Interno Bruto das nações, se comparada a outros setores. Dependendo da fonte, a fatia destas empresas no PIB representa entre 1,64\% e 2,6\% (ESTADOS UNIDOS, 2002; REINO UNIDO, 2005; YUKSAVAGE E FAHIM-NADER, 2005; CINGAPURA, 2007; KOBE, 2007). Sua importância, porém, transcende seu valor financeiro, se considerarmos a necessidade de seu uso no desenvolvimento da vida moderna. É difícil imaginar como seria o mundo de hoje caso não houvesse o serviço de distribuição de água potável, se a energia elétrica não estivesse disponível ou se o gás natural não fosse utilizado como fonte de energia.

Tal situação vem se mostrando cada vez mais evidente, visto que a demanda pelas chamadas utilidades públicas cresce continuamente em volume ano a ano, principalmente no caso de energia elétrica e gás natural, como se pode observar na Figura 1-1 e Figura 1-2.

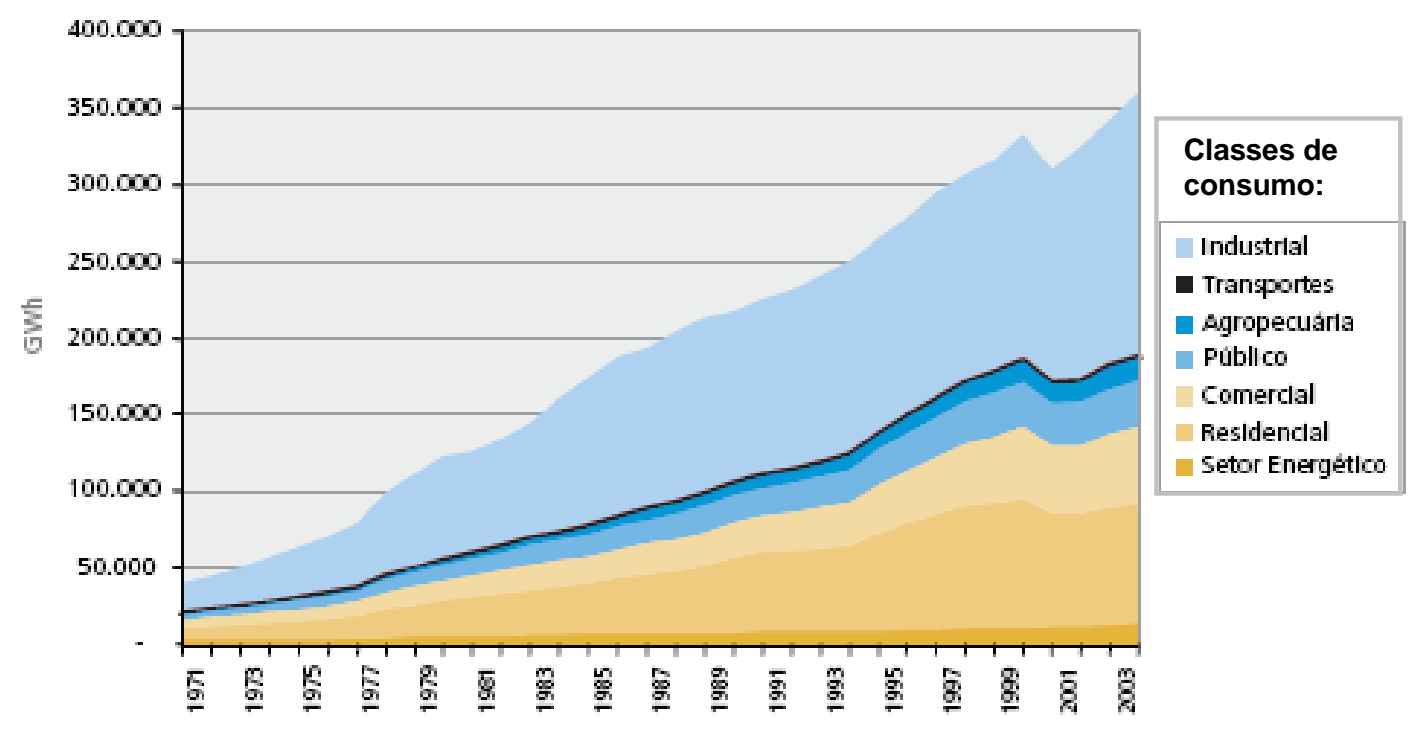

Figura 1-1 - Evolução no consumo setorial de energia elétrica (GWh) no Brasil entre 1971 e 2003, segundo classes de consumo (BRASIL, 2007) 


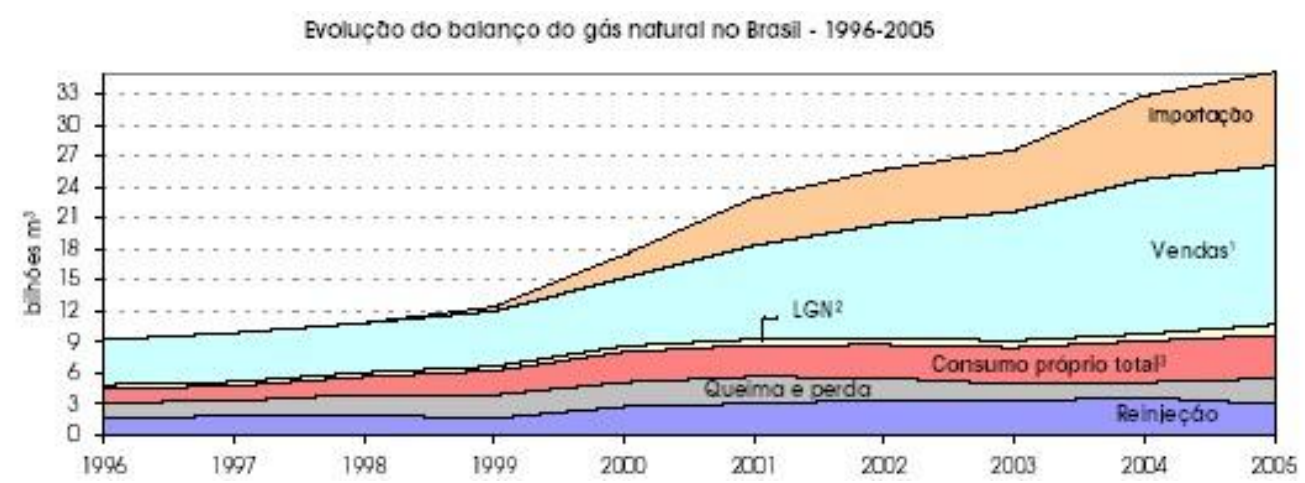

Figura 1-2 - Evolução do balanço do gás natural no Brasil - 1996-2005 (BRASIL, 2006)

$\mathrm{Na}$ literatura acadêmica, a maior parte dos artigos que tratam desses setores está focada na questão do monopólio natural - ou seja, nas estratégias criadas pelos governos para garantir a preocupação das empresas com o desempenho mesmo sendo geralmente únicas no mercado em que atuam. Geralmente, as soluções utilizadas se encaixam em uma das alternativas de regulação do monopólio descritas por Gómez-Ibáñez (2003), apresentadas na Figura 1-3:

- Manter a empresa sob capital público, com o próprio governo atuando diretamente sobre suas atividades (empreendimento público);

- Regular o preço e a qualidade de empresas privadas, impondo regras por meio de contratos de concessão (regulação);

- Liberar para que as empresas firmem contratos diretos com cada consumidor, a preços de mercado, atuando - por meio do poder judiciário somente quando houver "abuso de situação monopolista" (contratos privados). 
COMO O PREÇO E A QUALIDADE DO SERVIÇO

SÃO DETERMINADOS
ESTRATÉGIA DE REGULAÇÃO DO MONOPÓLIO

- Contratos Privados

Os clientes contratam diretamente a empresa privada

- Regulação

Os reguladores do governo definem os preços e os padrões de serviço para a empresa privada

- Empresa pública

O governo ou uma entidade sem fins lucrativos assume a responsabilidade primária de fornecer o serviço

Figura 1-3 - Diferentes soluções para o monopólio (adaptada de GÓMEZ-IBÁÑ̃EZ, 2003)

Entre os trabalhos que tratam das estratégias de regulação, além do próprio Gómez-lbáñez (2003), merecem destaque pela abrangência teórica Joskow (1997); Newbery (2001); Kessides (2005) e Parker (2003). Outros autores, como Price e Weyman-Jones (1996); Posner (1999); Bernstein e Sappington (1999); Branston (2000); Modiano (2000); Estache e Rossi (2002); Faria, Souza e Moreira (2005); Motta e Moreira (2006) e Hassanein e Khalifa (2007) procuram definir, com base em argumentos ou estudos empíricos, qual a melhor entre as alternativas de regulação apresentadas. As conclusões, no entanto, se mostram conflitantes entre si.

Em se tratando de produtividade das empresas de utilidades - ou seja, a busca de soluções para se fazer mais com menos recursos (SUMANTH, 1984; SINK; TUTTLE, 1989; TANGEN, 2005) - a literatura se mostra mais escassa, e restrita a temas estratégicos.

Alguns autores defendem, por exemplo, que o ganho de escala é uma forma de aumentar a produtividade nos mercados de utilidades. Schmalensee (1978); Lee, Oh e Kim (1999) e Jacob e Sioshansi (2002) afirmam que, nesses mercados, quanto maior a abrangência territorial da empresa, maior é a sua capacidade de diminuir os custos unitários de seus serviços, dada a possibilidade de interligação e otimização das redes. Jacob e Sioshansi (2002) adicionam ainda o "ganho de escopo" também mencionado por Kinnie, Hutchinson e Purcell (1998) - que ocorre quando uma mesma empresa passa a atuar em mais de um mercado (por exemplo, energia elétrica e gás), podendo assim integrar funções como atendimento ao cliente e faturamento. Por fim, na mesma linha, Hjalmarsson e Veiderpass (2002) estudam o 
"ganho de densidade", que consiste em aumentar o consumo da utilidade em uma região sem precisar expandir a rede de distribuição. No entanto, nos três casos, as estratégias sugeridas tratam de aspectos mercadológicos da empresa - abrangência territorial, escopo de fornecimento e densidade de consumo - e não das atividades operacionais executadas em campo pela empresa de distribuição.

Outro aspecto, tratado por Anderson (2001) e Smart (2005), contempla a discussão do estreitamento das relações entre cliente e fornecedor. Anderson (2001) discute a influência da privatização nas estratégias de compras e de relacionamento com fornecedores, enquanto Smart (2005) avalia as oportunidades de explorar o gerenciamento da cadeia de valor em empresas de utilidades.

Já as soluções operacionais para melhorar a produtividade nas empresas de utilidades são pouco exploradas pela literatura. Tsang (2002) e Rouls (2005), por exemplo, procuram propor medidas para melhorar a produtividade nos trabalhos de campo, tratando especificamente do "e-maintenance", ou seja, a tecnologia de informação de acesso remoto para a captura dos dados em operações de campo, por meio de computadores portáteis e transmissão sem fio.

No campo da melhoria da produtividade na manutenção, merecem destaque os trabalhos de Palmeira e Tenório (2002) e Sena (2002), que descrevem a experiência da implantação do $\operatorname{TPM}^{1}$ na Eletronorte, empresa estatal subsidiária da Eletrobrás e criada em 1973 com o objetivo de promover a implantação dos sistemas elétricos na região amazônica. Essa iniciativa foi a primeira de uma empresa do setor elétrico a receber reconhecimento internacional do JIPM - Japan Institute Plant of Maintenance (CARRIJO; LIMA, 2008).

Os exemplos de iniciativa de natureza semelhante, no entanto, são escassos e pouco abrangentes. De fato, como ressalta Smart (2005), as próprias empresas de distribuição de utilidades sentem geralmente menos compelidas a buscar novas técnicas para melhoria da produtividade, como é o caso das práticas da produção enxuta estudadas nesta dissertação. Isto se explica, segundo este autor, pelo fato de tais empresas não estarem sujeitas às forças que operam em outros setores industriais, tais como globalização, volatilidade da demanda, obsolescência dos produtos e mudanças nas tendências do consumidor. Soma-se às considerações

\footnotetext{
${ }^{1}$ Total Productive Maintenance, ou Manutenção Produtiva Total (descrita na Seção 3.3.1).
} 
deste autor a questão do monopólio natural já discutido nesta seção: como geralmente não há concorrência, a necessidade de implantar novidades para "ganhar mercado" tende a ser menor.

Há que se notar, no entanto, que mesmo empresas em mercados monopolistas estão sendo cada vez mais induzidas a buscar maior produtividade, geralmente com o próprio governo impondo regras com tal propósito e fazendo assim o papel do mercado. Um exemplo é o chamado Fator $X$, incluído em contratos de concessão mais recentes, que impõe à empresa de utilidades uma redução anual da tarifa de forma a repassar aos consumidores parte de seus ganhos de produtividade (BEESLEY, 1992; BRASIL, 2002; HROVATIN et al, 2005; LOWRY; GETACHEV; HOVDE, 2005).

Ao final, os principais beneficiados por soluções que melhorem a produtividade no fornecimento de água, energia elétrica e gás natural são os próprios consumidores - que passam a receber os serviços com mais qualidade, mais rapidez de atendimento às necessidades e menor custo - e, principalmente, a população ainda não atendida pelos serviços, para os quais a diminuição do custo tende a facilitar o acesso.

\subsection{Objetivo do estudo}

O objetivo desta dissertação é analisar a Rede de Distribuição de Utilidade (RDU) como sistema produtivo, verificando possíveis meios para se melhorar seus processos e, assim, proporcionar maior qualidade, menor custo e menor prazo de entrega ao cliente.

Considerando-se a escassez de ferramentas desenvolvidas especificamente para este setor, opta-se por examinar a aplicabilidade de práticas já consagradas em outros setores produtivos da economia e investigar seu potencial de aplicação no contexto das RDUs.

Uma possível solução que as empresas de RDU poderiam adotar em seus processos de melhoria da produtividade é a da produção enxuta, sistema desenvolvido pela Toyota Motor Company do Japão após a Segunda Guerra Mundial para organizar e gerenciar o desenvolvimento de produtos, operações, fornecedores e relações com o cliente. Esse sistema é descrito detalhadamente no 
Capítulo 3 e se baseia no princípio de que a melhoria da produtividade só é obtida por meio da busca incessante da eliminação de desperdícios na produção, sendo desperdício entendido como qualquer atividade que consome recursos, mas não agrega valor ao cliente (WOMACK; JONES, ROOS, 1992; OHNO, 1997; LEI, 2003; LIKER, 2005; DENNIS, 2008). Ao longo dos anos, este princípio serviu de base para o desenvolvimento de diversas técnicas de eliminação de desperdícios, sendo que algumas delas são descritas no Capítulo 3.

Estudos recentes demonstram que as práticas da produção enxuta, embora tenham sido originadas na indústria automobilística, podem ser adaptadas para aplicação nos mais diversos setores da economia (SAYER; WILLIAMS, 2007). Exemplos de sucesso na extensão de aplicações da produção enxuta já são encontrados, por exemplo, nos setores de serviços (BOWEN, YOUNGDAHL, 1998; ARBÓS, 2002; SWANK, 2003; GEORGE, 2004); escritórios (KRINGS; LEVINE; WALL, 2006; MALEYEFF, 2006), construção civil (KOSKELA, 1992; BALLARD; HOWELL, 1998; BALLARD, 2000; BERTELSEN; SACKS, 2002, 2007; CHEN; REICHARD; BELIVEAU, 2006, 2007) e indústrias de processo contínuo (BILLESBACH, 1994; COOK; ROGOVSKY, 1996; ABDULLAH, 2003; ABDULMALEK; RAJGOPAL; NEEDY, 2006; HA, 2007).

Esta dissertação se propõe a analisar as oportunidades de adaptação e o potencial de aplicação destas práticas em mais um setor específico: o setor constituído pelas Redes de Distribuição de Utilidades (RDUs). 


\section{As Redes de Distribuição de Utilidades (RDUs)}

Este capítulo apresenta o objeto de pesquisa desta dissertação, ou seja, as Redes de Distribuição de Utilidades (RDUs), baseando-se em suas principais características, de forma a especificar os limites de desenvolvimento do estudo a ser desenvolvido.

\subsection{Posicionamento das RDUs entre os setores de serviços}

Nessa seção, as Redes de Distribuição de Utilidades são posicionadas no universo dos setores de serviços, através da efetuação de três cortes:

- O primeiro corte distingue os setores que podem ser considerados como "Utilidades" daqueles que não o podem.

- O segundo corte verifica, entre os setores de utilidades, quais utilizam redes fixas (as "Redes de Utilidades").

- O terceiro e último corte seleciona, entre as redes de utilidades, aquelas que se caracterizam especificamente como Redes de Distribuição de Utilidades (RDUs).

\subsubsection{Primeiro corte: "Utilidades"}

O termo "utilidades" é um neologismo em português com origem no termo em inglês utilities, como explicam Trajano, Limmer e Longo (1990). Ele engloba todos os setores cuja principal característica em comum - que fez com que autores desde o início do século XX (RAYMOND, 1925; DIMOCK, 1933; WILSON; HERING; EUTSLER, 1936; JONES; BIGHAM, 1937) os colocassem em um mesmo grupo - é a essencialidade do serviço prestado para a população. Todos classificam os serviços prestados por provedores de utilidades como indispensáveis para o bem estar do público consumidor, e entendem que cabe ao poder público garantir a disponibilização dos mesmos, de forma direta ou indireta.

Atualmente, a essencialidade das RDUs se mostra ainda mais evidente, como mostram as seguintes conclusões, publicadas pela Organização Internacional do Trabalho (OIT): 
1. As utilidades públicas são serviços essenciais que desempenham um papel vital na economia e no desenvolvimento social, uma vez que têm um impacto extensivo na saúde e sobrevivência das pessoas e na produtividade da economia em geral. Mais progresso deve ser feito, particularmente em países em desenvolvimento, para facilitar o acesso destes serviços ao maior segmento possível da população.

2. As utilidades públicas devem servir ao interesse público. Quer sejam fornecidas de forma pública ou privada, os governos são os maiores responsáveis por estes serviços essenciais, por meio de uma estrutura regulatória transparente e responsável, de modo a garantir o acesso universal e confiável e a continuidade do serviço, com foco específico nas áreas ainda não servidas. $\left(\mathrm{OIT}^{2}, 2003\right.$, p. 28)

Uma característica das RDUs que reforça ainda mais sua essencialidade foi enfatizada por Gómez-lbáñez (2003), para quem, em alguns casos, o benefício com o uso das mesmas vai além dos usuários diretos. Por exemplo: a distribuição de água protege o público em geral da disseminação de doenças e da contaminação do meio ambiente, e a iluminação noturna ajuda na segurança da circunvizinhança contra acidentes e crimes.

A Figura 2-1 destaca, entre os serviços em geral, exemplos dos que são comumente considerados utilidades.

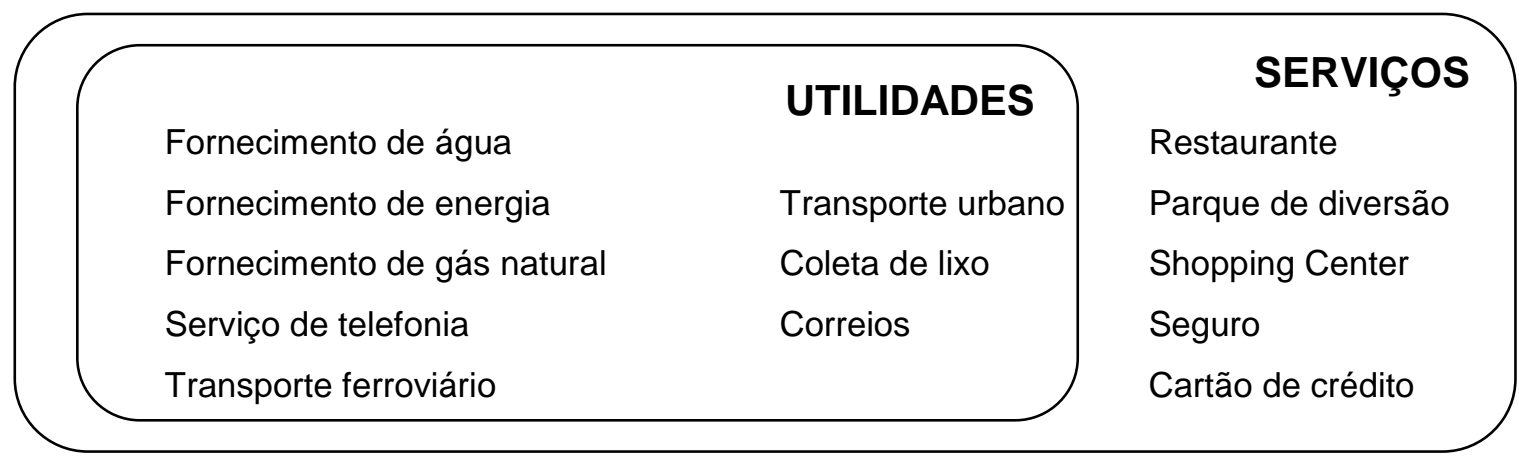

Figura 2-1 - O grupo das utilidades e os serviços em geral

\subsubsection{Segundo corte: "Redes de Utilidades"}

A expressão Network Utilities (“Utilidades por Rede”) é apresentada por Newbery $(1998,2001)$ com o intuito de separar as utilidades que usam uma infraestrutura permanente das demais. Segundo este autor, as Network Utilities são "as utilidades públicas que necessitam de uma rede fixa [própria] para entregar seus serviços" (NEWBERRY, 2001, p. 5). Isto exclui os serviços de utilidades que não

2 Texto extraído da ata da Reunião Tripartite sobre Desafios e Oportunidades Enfrentados pelas Utilidades Públicas, promovida pela OIT em Genebra, entre 19 e 23 de maio de 2003, da qual participaram representantes de governos, empresas e trabalhadores. 
necessitam de rede ou que utilizam redes de terceiros como transporte urbano, coleta de lixo e correios (Figura 2-2).

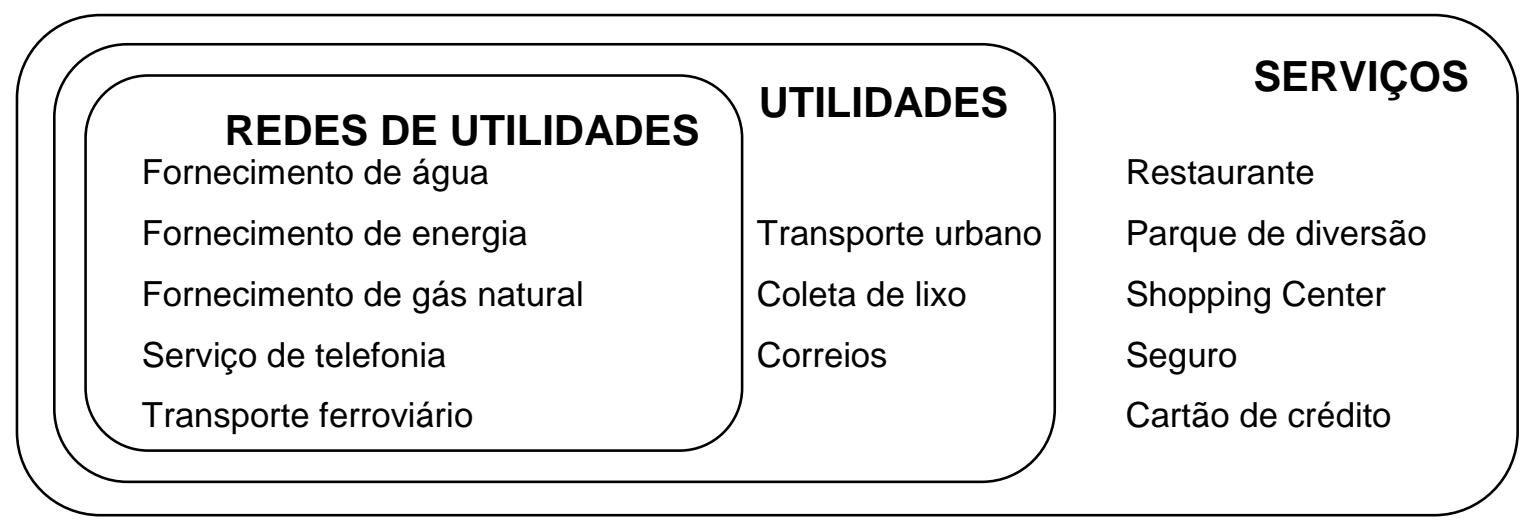

Figura 2-2 - O grupo das Redes de Utilidades

$\mathrm{O}$ uso de redes se justifica quando as mesmas oferecem maior viabilidade econômica em relação ao transporte em recipientes móveis para distribuição de utilidades, dadas as economias de escala geradas pelo primeiro e o alto custo unitário de distribuição do segundo. Como exemplo, uma comparação econômica entre as duas soluções foi desenvolvida por Kariuki e Shwartz (2005), ao promoverem um estudo para o Banco Mundial com base em dados de 93 localidades em 47 países. O estudo concluiu que o custo do metro cúbico de água distribuído por rede (seja esta pública ou privada) é consideravelmente mais baixo que 0 praticado pelos postos de venda, onde o consumidor busca o recipiente contendo o produto, e pelos distribuidores móveis (como caminhões-pipa e carroceiros). Os resultados estão apresentados na Figura 2-3.

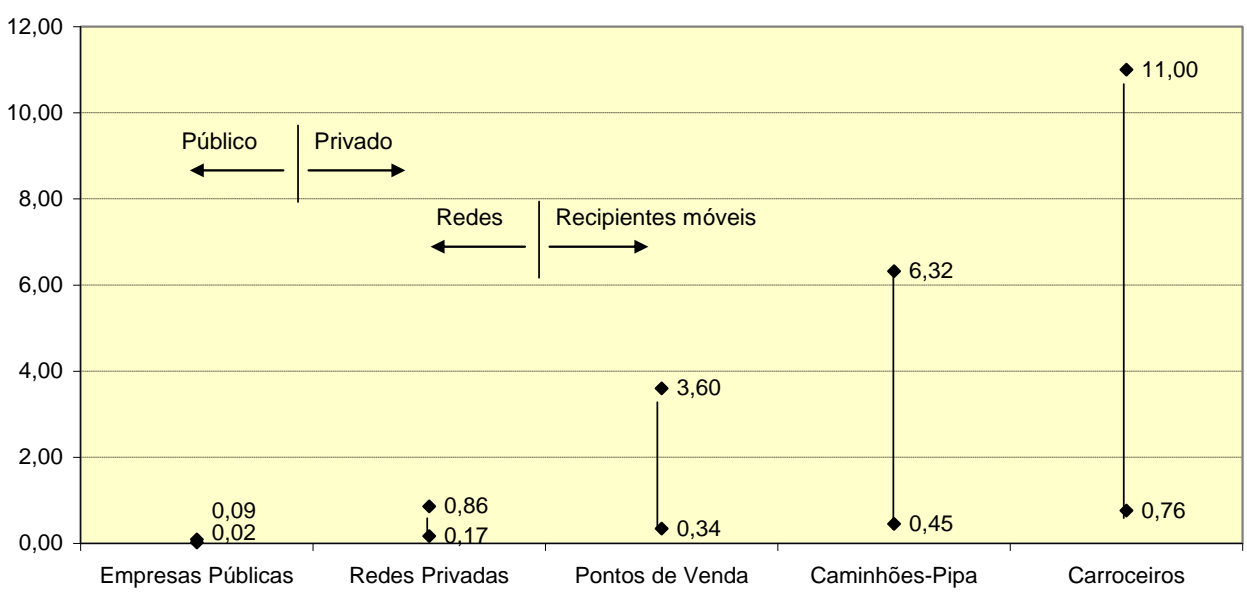

Figura 2-3 - Preço da água por tipo de provedor de serviço, em US\$ por metro cúbico (KARIUKI, SCHWARTZ, 2005). 
Cabe mencionar que, como lembram Kariuki e Schwartz (2005), a distribuição de utilidades por meio de postos de venda e distribuidores móveis ainda é praticada em algumas localidades, principalmente onde há baixa cobertura das redes ou ineficiência das redes existentes, ou em locais remotos e de difícil acesso. Estes meios de distribuição, no entanto, não fazem parte do escopo desta dissertação, que está focada especificamente na distribuição por redes.

\subsubsection{Terceiro corte: "Redes de Distribuição de Utilidades"}

As Redes de Utilidades, por sua vez, ainda podem ser divididas em dois grupos, conforme explicado a seguir e ilustrado na Figura 2-4 e Figura 2-5:

- Na distribuição de água, gás e energia elétrica, o bem transportado flui continuamente pela rede e sempre na mesma direção - da fonte para os consumidores. Uma rede de distribuição, depois de construída, opera de forma contínua, transporta um bem que varia pouco em características e somente requer intervenção humana para controle e manutenção.

- Já nas redes utilizadas na ferrovia e na telefonia fixa, há variabilidade tanto nos elementos transportados - diferentes pessoas, cargas ou informações quanto nos caminhos percorridos por estes elementos - de qualquer ponto para qualquer outro ponto da rede. Assim, a própria característica destas redes exige uma maior intervenção durante a sua operação, seja de forma humana ou eletrônica, para lidar com esta variabilidade.

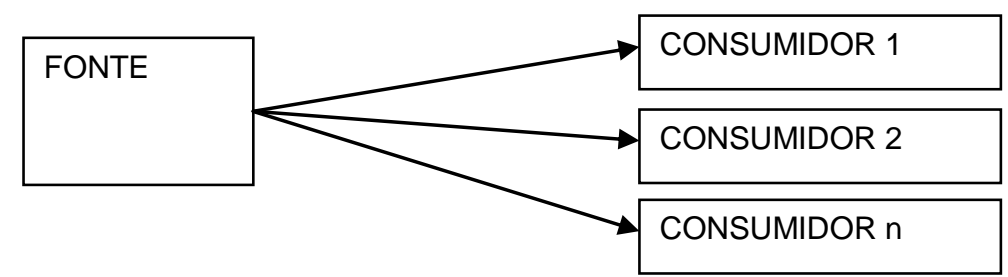

Figura 2-4 - Serviços de distribuição de água, gás e energia elétrica

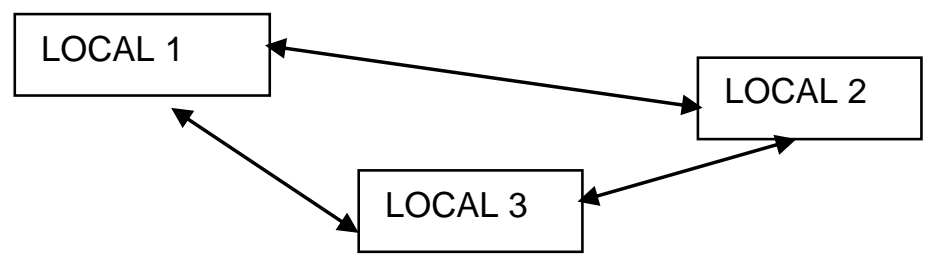

Figura 2-5 - Serviços de ferrovia e telefonia fixa 
Para restringir o foco deste estudo a um grupo de utilidades similares entre si, optou-se por analisar somente as Redes de Utilidades cuja finalidade se restringe à distribuição de um bem até os consumidores por meio de uma "Rede de Distribuição de Utilidade" (RDU) específica. Sua posição frente aos grupos de empresas previamente analisados é delimitada na Figura 2-6.

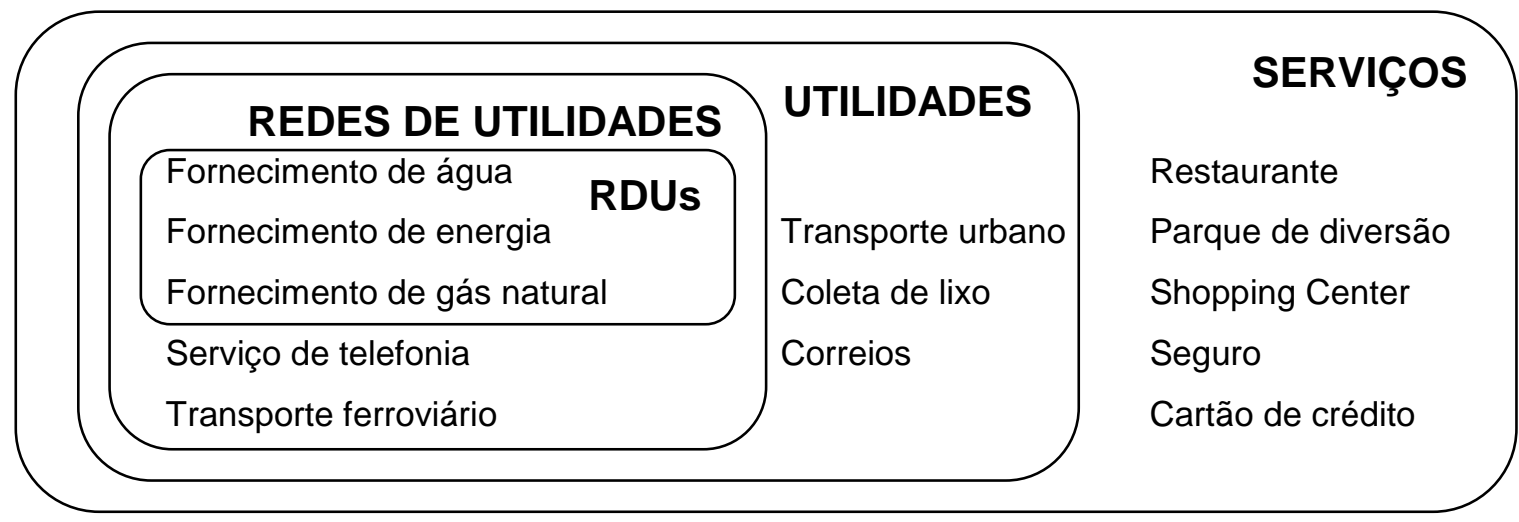

Figura 2-6 - O grupo das RDUs

Considera-se então, para esta dissertação, que o grupo das RDUs abrange os seguintes setores responsáveis pelos seguintes ativos:

- Rede de distribuição de água;

- Rede de distribuição de energia elétrica;

- Rede de distribuição de gás natural;

\subsection{Posicionamento das RDUs nas cadeias de fornecimento de água, energia elétrica e gás natural}

Analisada a classificação das RDUs entre os setores em geral, resta entender como as mesmas se situam nas cadeias de fornecimento das quais fazem parte: água, energia elétrica e gás natural.

\subsubsection{A cadeia de fornecimento da água}

A cadeia de fornecimento da água é didaticamente apresentada pela empresa de saneamento SABESP, em material disponibilizado em seu site $^{3}$ e apresentado na

\footnotetext{
${ }^{3}$ O material completo se encontra no site www.sabesp.com.br, acessado em 15/10/2008.
} 
Figura 2-7. A seqüência de etapas que constitui esta cadeia é descrita a seguir. A numeração indicada aponta a posição de cada etapa na Figura 2-7:

- Captação e bombeamento: retirada da água da represa (01), por meio da captação e o bombeamento (02) para a Estação de Tratamento de Água.

- Tratamento: purificação da água pelos processos de pré-cloração, préalcalinização e coagulação (03); floculação (04); decantação (05) e filtração (06).

- Beneficiamento: adição de cloro e flúor (07), respectivamente com as funções de destruir microorganismos e contribuir para a prevenção de cáries dentárias.

- Armazenamento: estocagem da água em reservatórios de distribuição (08), e transporte através de tubulações maiores (adutoras) até reservatórios de bairros (09), espalhados em regiões estratégicas das cidades.

- Distribuição: escoamento da água através das redes de distribuição (10) destinadas a levar o produto a cada cliente (11).

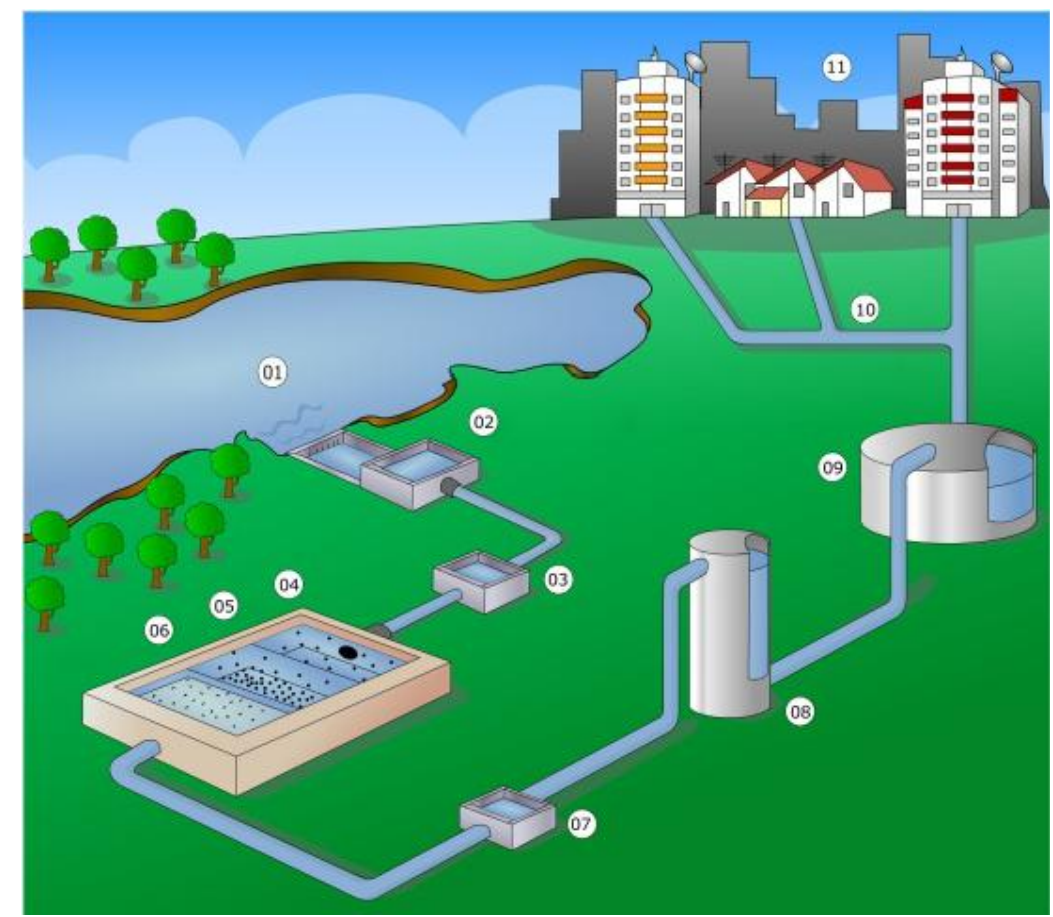

Figura 2-7 - A cadeia de suprimento da água. Fonte: SABESP (www.sabesp.com.br, acesso em 15/10/2008) 


\subsubsection{A cadeia de fornecimento da energia elétrica}

A cadeia de fornecimento da energia elétrica é diagramada por Leão (2008), conforme Figura 2-8, e explicada em detalhes por Sanderson (1999). Pode-se dividir seu fluxo em três partes:

- Geração: transformação de uma energia presente na natureza em energia elétrica. A energia utilizada pode ser, por exemplo: a energia cinética da água ou do vento, a energia química dos combustíveis fósseis, ou a energia nuclear de elementos radioativos. Sanderson (1999) explica que o conceito básico das usinas sempre envolve dois processos fundamentais: primeiro, a energia da fonte é utilizada para girar turbinas; segundo, a movimentação destas turbinas gera energia elétrica em alta voltagem.

- Transmissão: transporte de energia elétrica em grandes quantidades, por meio de redes de transmissão de alta voltagem até as redes de distribuição locais.

- Distribuição: transferência da eletricidade em alta voltagem, entregue em pontos de acesso da rede de distribuição, para redes de distribuição locais, que reduzem a voltagem e fornecem a conexão conforme as necessidades do consumidor final.

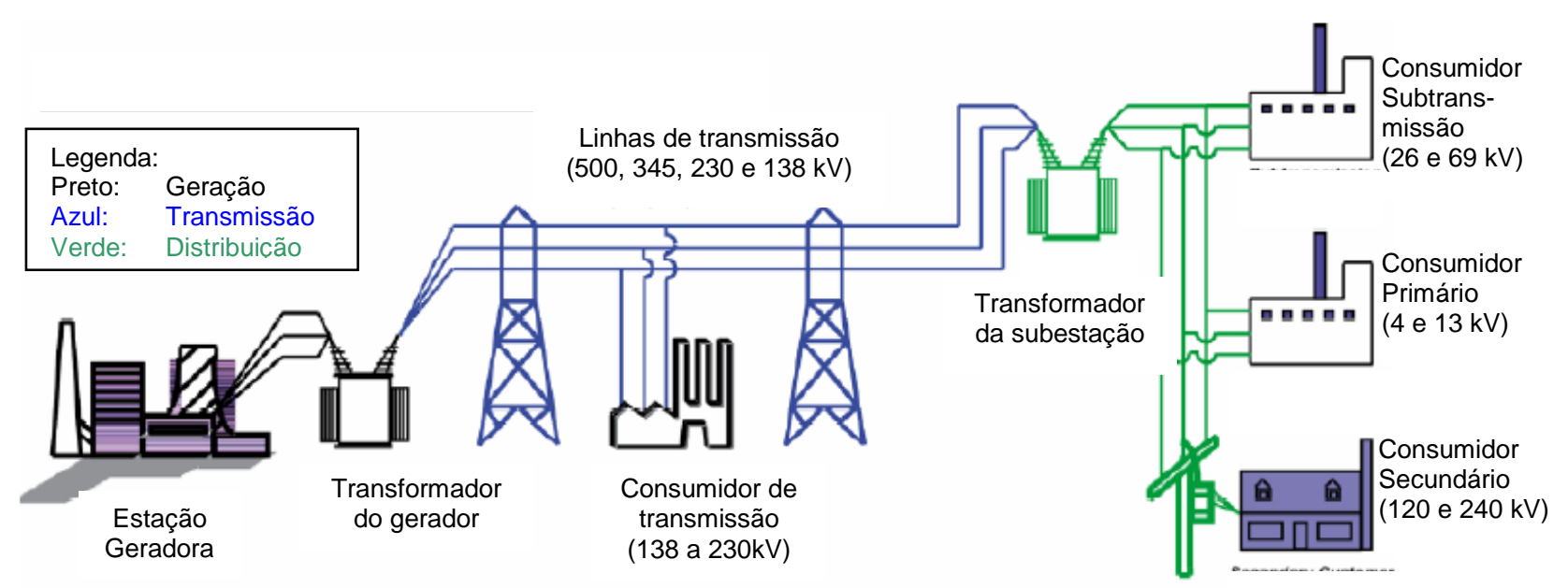

Figura 2-8 - A cadeia de suprimento do sistema elétrico. Adaptada de Leão (2008) 


\subsubsection{A cadeia de fornecimento do gás natural}

A cadeia de fornecimento do gás natural é apresentada pela empresa Lexecon (2006), em trabalho desenvolvido para o American Petroleum Institute (API), conforme Figura 2-9. Basicamente, ela é composta das seguintes etapas:

- Exploração e produção: procura por reservatórios de gás natural subterrâneos, em áreas terrestres ou marítimas, e posterior extração do produto por meio da perfuração de poços.

- Processamento: remoção das impurezas e separação de outros produtos, tais como água e petróleo, preparando um gás seco de acordo com os padrões esperados para transporte em tubulações em alta pressão.

- Transporte: utilização de tubulações de alta pressão para transporte do gás, das áreas de produção até as áreas de estocagem e distribuidoras locais.

- Estocagem: armazenamento de gás natural para utilização em períodos de pico, cuja demanda os sistemas de produção e entrega não são capazes de suprir.

- Distribuição: rede de tubulações que obtém o gás natural das redes de alta pressão, reduz a pressão, armazena e transporta aos consumidores finais dos segmentos residencial, comercial e industrial.

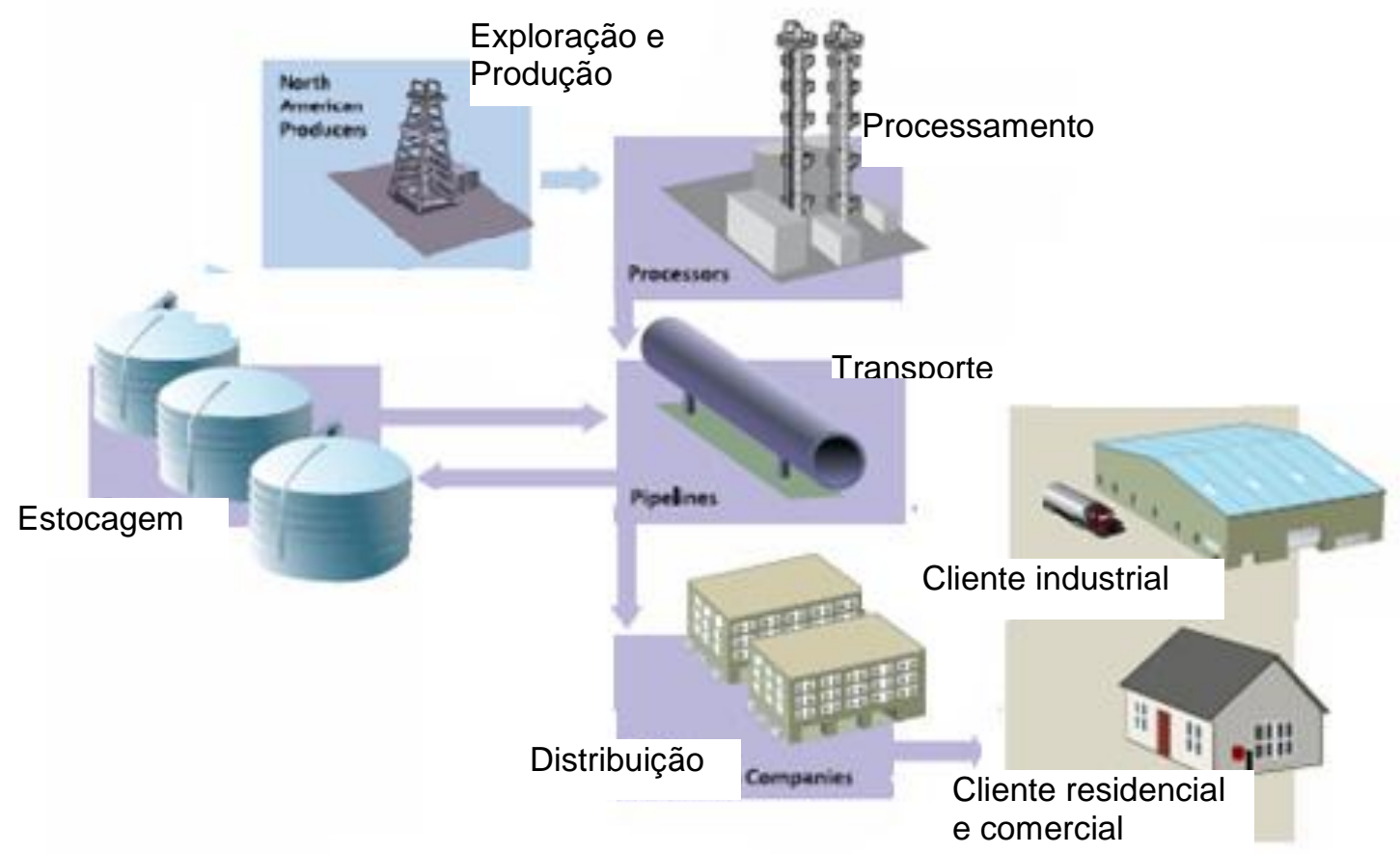

Figura 2-9 - O fluxo do gás natural. Adaptada de Lexecon (2006) 


\subsubsection{Posicionamento das RDUs nas cadeias apresentadas - a definição de RDU}

Analisando-se conjuntamente os fluxos de água, energia elétrica e gás natural apresentados, percebe-se que cada um tem suas particularidades, principalmente na forma que o produto em questão é extraído da natureza e transformado naquele a ser utilizado pelo consumidor.

No entanto, a obtenção do "produto acabado" - seja a água pura, seja a energia na forma elétrica, seja o gás natural puro - não significa o término do processo. Isto porque, nos três casos, mesmo que o produto seja estocado, existe a necessidade de se fazer com que o mesmo esteja disponível não em seu local de obtenção, mas sim no local do consumo - ou seja, na instalação do cliente ${ }^{4}$. Para tanto, é necessário que o produto acabado seja, de alguma forma, transportado entre estes dois pontos, e é para esta finalidade que existem as Redes de Distribuição de Utilidades (RDUs).

O termo Rede de Distribuição de Utilidade, considerado no presente trabalho, pode ser então definido conforme o Quadro 2-1.

Quadro 2-1 - Definição de RDU

\section{DEFINIÇÃO DE REDE DE DISTRIBUIÇÃO DE UTILIDADE (RDU):}

Conjunto de tubos ou cabos necessários para transportar a utilidade, até as instalações dos clientes para pronto consumo

Seu posicionamento nas cadeias de suprimento das utilidades está mostrado na Figura 2-10.

\footnotetext{
${ }^{4}$ Por instalação do cliente, entenda-se a instalação de qualquer natureza (residencial, comercial ou industrial, etc.) em que o cliente utiliza ou pretende utilizar o produto fornecido por uma Rede de Distribuição de Utilidade.
} 


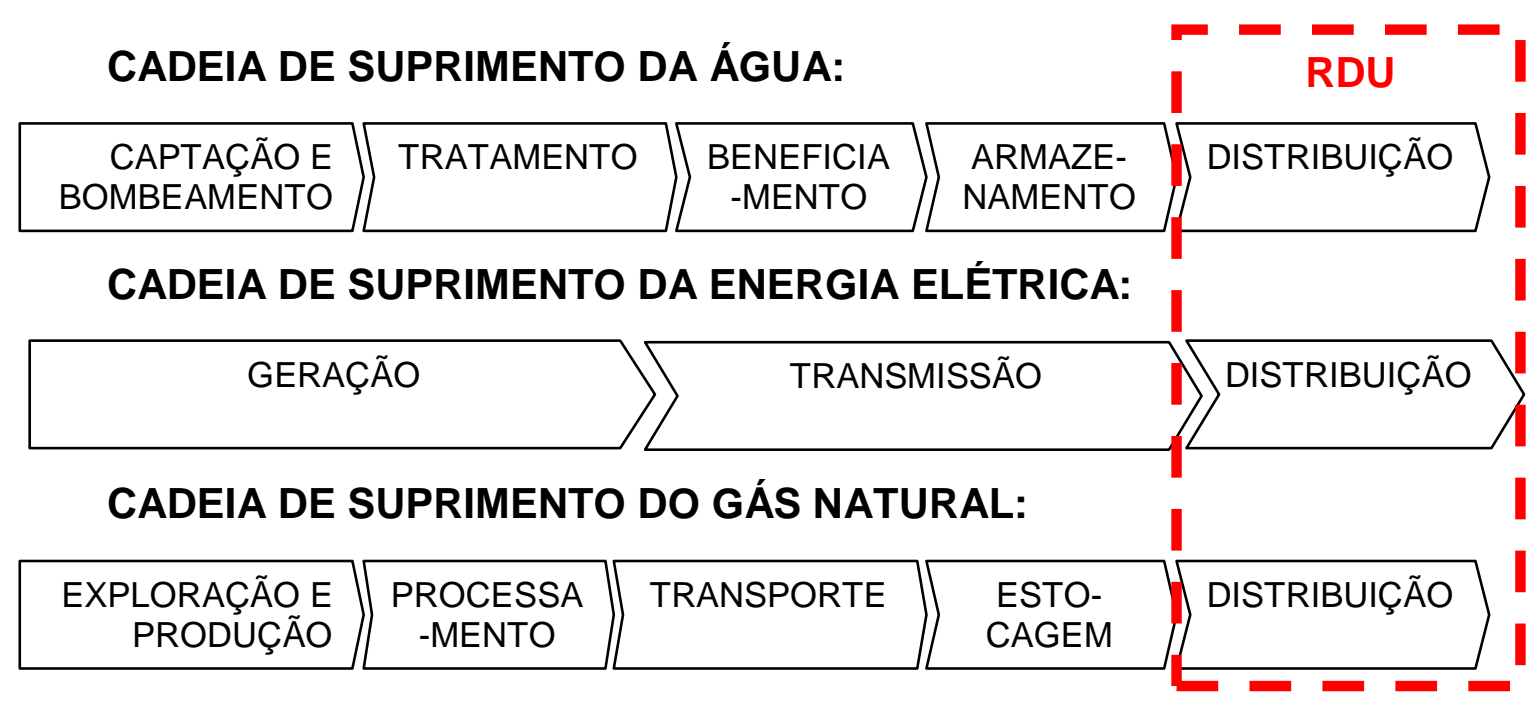

Figura 2-10 - As RDUs nas cadeias de suprimento da água, energia elétrica e gás natural

É importante observar que esta dissertação foca especificamente no processo de distribuição, nas três cadeias, não levando em conta se os processos à montante na cadeia são executados pela mesma empresa ou não.

\subsection{O processo produtivo de uma RDU}

Esta seção visa entender o processo produtivo de uma RDU, por meio da análise de seu valor sob o ponto de vista do cliente.

\subsubsection{O valor da RDU}

Womack e Jones (1996) explicam que o ponto de partida inicial para analisar qualquer sistema produtivo é identificar o valor desse sistema, que só pode ser definido pelo cliente final. Segundo esses autores, o valor só é significativo quando expresso em termos de um produto específico que atenda às necessidades do cliente a um preço específico em um momento específico.

Conforme verificado, as RDUs são utilizadas para distribuição de utilidades aos consumidores finais. Tais redes participam do processo produtivo de empresas distribuidoras, cuja principal função, segundo Reilly (2008), é transferir algo de um ponto ' $A$ ', onde ele se encontra, a um ponto 'B', onde ele é usado.

O valor da distribuição é também analisado por Stewart e Dewhurst (1976) por meio de sua comparação com a manufatura: enquanto a manufatura adiciona valor 
aos bens em termos físicos ou de forma, a distribuição adiciona valor em termos de localização e tempo.

Este raciocínio é complementado por Reichhart e Holweg (2007. p. 3701), ao apresentarem o valor da distribuição, de forma geral, como (p. 3701): "fazer com que o produto certo esteja disponível ao cliente final no momento certo e no local certo". No caso específico de uma RDU, os elementos expostos pelos autores podem ser definidos a seguir:

- O produto certo é a água, a energia elétrica ou o gás natural na quantidade e qualidade desejada pelo cliente.

- O momento certo é qualquer momento que o cliente precisar do produto, por exemplo, quando ele abrir um registro ou ligar um equipamento elétrico. Como este momento é aleatório, espera-se que a distribuição numa RDU seja mantida de forma contínua e ininterrupta.

- O local certo é a própria instalação do cliente, ou seja, o local em que ele pretende usar o produto.

- O meio escolhido para disponibilizar o produto certo, no momento certo e no local certo, é a rede de distribuição, devido à maior viabilidade econômica frente a outras soluções de transporte (ver Seção 2.1.2).

Por conseqüência, o valor oferecido pelas RDUs pode ser definido conforme o Quadro 2-2.

Quadro 2-2 - O valor da RDU

VALOR DA REDE DE DISTRIBUIÇÃO DE UTILIDADE (RDU)

Fazer com que, por meio de uma rede de distribuição, a utilidade esteja disponível, na quantidade e qualidade necessária, de forma contínua e ininterrupta, na instalação do cliente.

\subsubsection{A cadeia de valor de uma RDU}

Definido o valor do sistema produtivo, Womack e Jones (1996) recomendam que se faça uma análise da cadeia de valor para a entrega do mesmo. Esta seção tem o intuito de apresentar a cadeia de valor típica de uma RDU, representada pelo 
conjunto de atividades que são necessárias para que a utilidade passe a estar disponível a cada novo cliente e que se mantenha disponível após a ligação.

Segundo os autores, as cadeias de valor são constituídas de três fluxos principais - por eles denominados tarefas - representados esquematicamente por meio da Figura 2-11:

- O fluxo da concepção ao lançamento do produto (desenvolvimento) ${ }^{5}$;

- O fluxo do recebimento do pedido ao faturamento (gerenciamento da informação);

- O fluxo da matéria-prima à entrega do produto acabado ao cliente (transformação física).

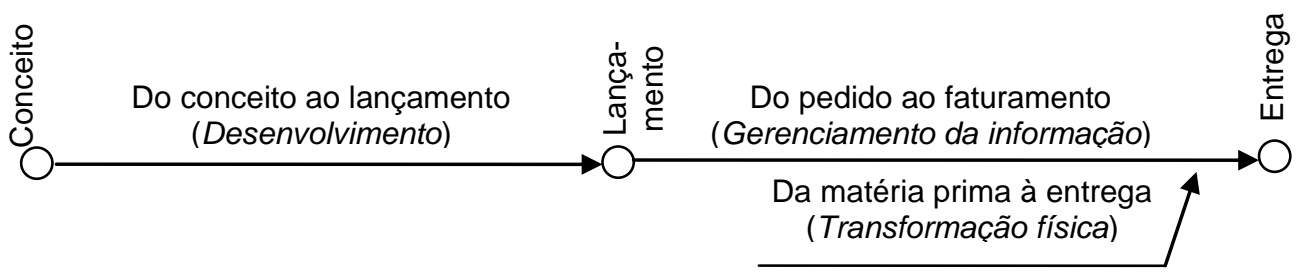

Figura 2-11 - Os fluxos na manufatura (baseada em PICCHI, 2001, p. 7)

Segue uma descrição de como estes fluxos se aplicam ao contexto de uma RDU.

\section{Da concepção ao lançamento do produto}

O fluxo de desenvolvimento, desde a concepção ao lançamento do produto, ocorre na manufatura quando um produto é criado ou adaptado de forma a atender às novas necessidades do cliente.

No caso das RDUs, não existe propriamente o desenvolvimento de um novo produto, já que as características do produto distribuído (água, energia elétrica, gás natural, etc.) devem satisfazer padrões constantes. Existe, porém, a necessidade de se "lançar" este mesmo produto para mais clientes, visto que o mesmo ainda não está disponível para todos (ver Seção 2.1.1). Sendo assim, o fluxo de desenvolvimento para uma empresa de RDU corresponde à construção de novas redes para abastecimento de novos clientes (processo de expansão e construção da

\footnotetext{
${ }^{5}$ Womack e Jones (1996) atribuem a este fluxo o nome de Solução de Problemas. Nesta dissertação, o nome do fluxo é trocado por desenvolvimento, de forma a diferenciá-lo da atividade de Solução de Problemas, que é uma das práticas fundamentais da produção enxuta (ver Seção 3.2.4).
} 
rede). O cliente, neste caso, é representado pelo cidadão que ainda não recebe a utilidade em questão, mas deseja poder recebê-la.

Para se entender as atividades que compõem este processo, pode-se recorrer às considerações sobre a cadeia de valor no contexto da construção civil disponíveis na literatura. Devem-se levar em conta, no entanto, as peculiaridades da construção de uma RDU que a distinguem da construção civil:

- Na construção civil, a obra em questão é o próprio produto a ser fornecido para o cliente, e seu término caracteriza a entrega do produto acabado. Assim, na própria construção estão incluídos os fluxos de desenvolvimento, gerenciamento da informação e transformação física.

- Já na construção de uma RDU, a rede construída não é o produto a ser fornecido, e sim o meio a ser utilizado para fornecer o produto, representado pela utilidade em questão (água, energia elétrica, gás natural). Por conseqüência, seu término não representa a entrega, mas sim o "lançamento" da disponibilidade do produto a um novo cliente, e a construção corresponde somente ao fluxo de desenvolvimento.

Levando-se em consideração tais diferenças, pode-se dizer que o fluxo de desenvolvimento para uma empresa operadora de RDU é composto pelos seguintes componentes de fluxo, apresentados por Picchi (2001) para a construção civil e esquematizados na Figura 2-12:

- Fluxo de construção: engloba desde a identificação das necessidades da construção, planejamento geral do projeto, desenho, contratação e monitoramento da construção e ligação do cliente, dando início à entrega da utilidade para o cliente final.

- Fluxo de projeto: envolve o desenvolvimento de soluções para a expansão da RDU até a instalação do cliente.

- Fluxo de obra: compõe-se das atividades necessárias para a implantação de tubos ou cabos ao longo do trajeto desde a fonte até a instalação do cliente.

- Fluxo de suprimentos: envolve a cadeia de fornecimento de materiais e equipamentos para a execução da obra. 


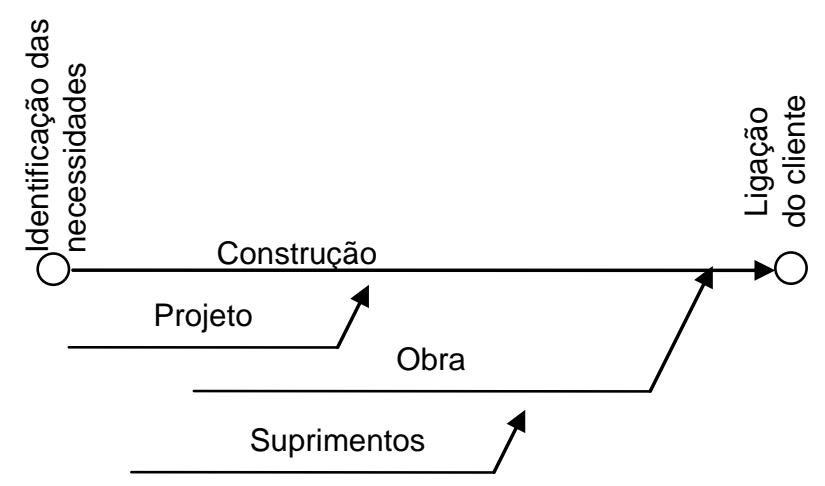

Figura 2-12 - Fluxos da construção no contexto de uma RDU (baseada em PICCHI, 2001, p. 8)

\section{Do recebimento do pedido ao faturamento}

O momento do lançamento de um novo produto na manufatura corresponde, na RDU, ao evento em que um novo cliente é ligado à rede, ou seja: quando um novo ramal é construído desde a rede construída na rua até a instalação deste cliente e a utilidade é consumida pela primeira vez. Neste instante, o cliente deixa de ser um potencial consumidor da utilidade e passa a ser um consumidor de fato.

A partir de então, a utilidade passa a ser fornecida de forma contínua, não havendo propriamente um "recebimento do pedido" como na manufatura. Para utilizar o produto, o cliente pode simplesmente abrir um registro de água ou gás natural em sua própria instalação ou acionar um equipamento ligado à rede elétrica.

Há, no entanto, a necessidade de informação quanto ao consumo da utilidade pelo cliente, que é obtida por meio da medição periódica de consumo - geralmente mensal - e envio de fatura para pagamento.

Com exceção da medição do consumo, a comunicação entre cliente e prestador de serviço geralmente ocorre somente no caso de anomalias no fornecimento, tais como: desabastecimento, problemas de qualidade, dúvidas de faturamento e reclamações diversas. Nestes casos, é necessário um trabalho específico de atendimento ao cliente.

\section{Da matéria-prima ao produto acabado nas mãos do cliente}

Conforme visto na Seção 2.3.1, as empresas de distribuição têm como particularidade o fato de não adicionar valor ao bem oferecido em termos físicos ou de forma, mas em termos de sua localização e disponibilidade no tempo. Nas RDUs, a distribuição é feita por meio de redes próprias utilizadas exclusivamente para este 
fim, que são geralmente projetadas para transportar a utilidade automaticamente em condições normais de operação.

Assim, no fluxo de transformação, a intervenção humana só se mostra necessária para duas atividades:

- Inspecionar e atuar periodicamente nas instalações físicas da rede, de forma a garantir a continuidade e a qualidade do fornecimento do serviço, evitando problemas como interrupção do serviço, vazamentos, contaminações, danos, fraudes, entre outros (manutenção preventiva);

- Trabalhar para que, no caso da ocorrência de alguma anomalia, as condições normais de fornecimento sejam recuperadas o mais rápido possível (manutenção corretiva).

Em resumo, a cadeia de valor de uma RDU se mostra conforme a Figura 2-13.

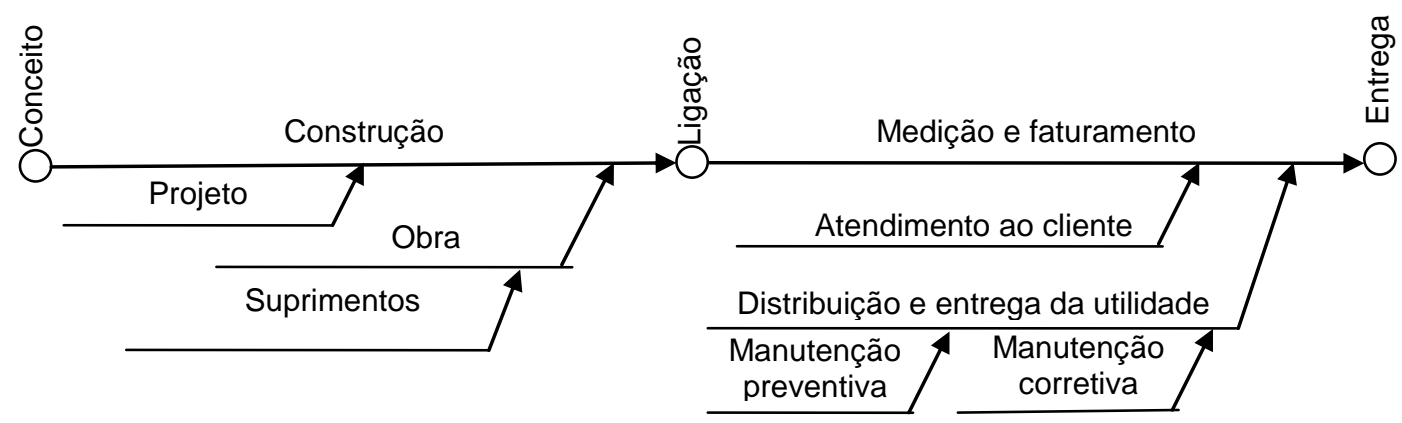

Figura 2-13 - Cadeia de valor de uma RDU

Vale ressaltar que a cadeia de valor apresentada na Figura 2-13 visa somente a explicar os fluxos necessários para o fornecimento da utilidade aos clientes, mostrando as relações de precedência entre as atividades que os compõem. Sendo assim, não foram incluídos outros fluxos como os de materiais ou de informações entre as atividades mencionadas.

\subsection{Os processos abordados na dissertação - construção e manutenção de RDU}

A cadeia de valor de uma RDU é constituída de todos os processos mostrados na Figura 2-13. No entanto, para definição do escopo desta dissertação, parte-se do pressuposto que os processos de medição e faturamento e de atendimento ao cliente tendem a se assemelhar aos de outros setores, podendo-se aproveitar 
muitos dos conceitos sobre racionalização de processos da literatura já disponível sobre esses temas. Já o processo de distribuição e entrega da utilidade ocorre geralmente de forma automática, não sendo necessária intervenção humana, o que torna irrelevante seu estudo específico como um processo que envolve trabalho produtivo.

Por conseqüência, optou-se por focar nos processos de construção e de manutenção da rede, por serem nestes em que a cadeia de valor de uma RDU se mostra mais peculiar, diferenciando-a da cadeia de valor de outros setores, o que sugere a necessidade de desenvolver uma investigação específica sobre a aplicabilidade das práticas de produção enxuta neste contexto.

Para delimitar claramente o escopo deste trabalho de pesquisa, foram ainda assumidas as seguintes considerações quanto aos processos de construção e de manutenção:

- No processo de construção, considera-se que o planejamento já foi executado e as necessidades do usuário já estão definidas. Assim, as atividades abordadas se resumem ao desenvolvimento do projeto, obtenção dos suprimentos e execução da obra até o momento em que ela se torna pronta para ligação do cliente.

- No processo de manutenção, consideram-se todas as atividades de manutenção preventiva após a ligação do cliente, desenvolvidas de forma a garantir a continuidade e a qualidade do fornecimento do serviço.

Vale salientar que não são abordados os processos que envolvem a participação do cliente, como a ligação de um novo cliente ou a manutenção corretiva decorrente de um vazamento, falta de fornecimento ou fraude. O motivo da exclusão de tais processos é que o fato de serem executados na instalação do cliente exige uma perspectiva de análise diferente, focada na interação entre o cliente e o fornecedor, o que extrapola a abrangência proposta para esta dissertação.

A Figura 2-14 mostra os processos da cadeia de valor que são abordados no escopo deste trabalho: os processos de Construção e de Manutenção Preventiva. 


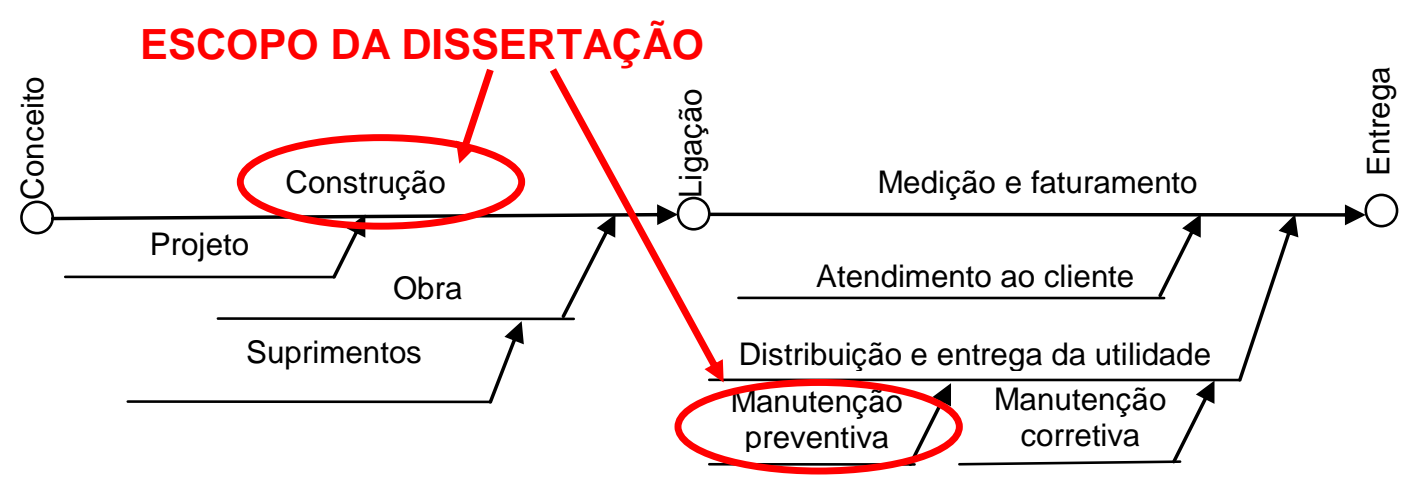

Figura 2-14 - O escopo da dissertação na cadeia de valor da RDU

Segue um levantamento das principais características destes processos.

\subsubsection{Características do processo de construção de uma RDU}

O processo de construção de uma RDU consiste na atividade de dispor tubos ou cabos ao longo de todo o caminho desde a fonte até a instalação do cliente, de forma a disponibilizar a utilidade a este cliente.

Para se analisar a construção de uma RDU como processo produtivo, pode-se recorrer às análises apresentadas na literatura para a indústria da construção civil, iniciadas por Koskela (1992) e discutidas anualmente nas conferências do IGLC International Group for Lean Construction (IGLC) ${ }^{6}$. Este tipo de adaptação é possível graças à generalização das abordagens desenvolvidas pelos membros do IGLC citados ao longo desta seção, cujas considerações não fazem diferenciação quanto ao tipo de estrutura construída.

Ballard e Howell $(1998)$ e Koskela $(1999,2000)$ explicam que a construção é essencialmente $o$ projeto e montagem de objetos fixos no local, e conseqüentemente possui, em certo grau, as seguintes características:

- Sete Pré-Condições;

- Unicidade;

- Produção em campo; e

- Organização temporária.

Cada característica é analisada separadamente a seguir, incluindo suas causas, conseqüências e aplicação no processo de construção de uma RDU.

\footnotetext{
${ }^{6}$ Os trabalhos estão disponíveis no site do IGLC (www.iglc.net).
} 


\section{Sete pré-condições}

Para explicar a primeira característica da construção, Koskela (2000) compara uma tarefa de construção a um processo de montagem: da mesma forma que a montagem só é possível se todas as peças estiverem disponíveis, a tarefa de construção (por exemplo, um dia de trabalho) só atinge os resultados buscados se todas as pré-condições para sua execução estiverem atendidas.

O autor enumera pelo menos sete pré-condições típicas para a execução de uma tarefa de construção, as quais são descritas a seguir e ilustradas na Figura 2-15, de Bertelsen et al (2007):

- Em primeiro lugar, nenhuma tarefa pode ser iniciada sem que as tarefas anteriores tenham se encerrado. Por exemplo: uma janela não pode ser colocada em uma parede que ainda não tiver sido levantada.

- Adicionalmente, como cada construção tem suas particularidades, a informação sobre o que se deve fazer precisa estar disponível, normalmente na forma de um projeto executivo ou ordem de serviço, visando garantir que a atividade esperada seja executada adequadamente.

- Da mesma forma, os materiais, a equipe de trabalhadores e os equipamentos devem ser devidamente reservados e transportados, de forma a estarem disponíveis no local e horário de execução da tarefa.

- Particularmente, na construção, o espaço também acaba por ser um recurso importante a ser disponibilizado. Isso porque várias equipes podem ter que executar tarefas no mesmo espaço (um quarto de uma casa, por exemplo), e o congestionamento de equipes pode dificultar - ou mesmo impedir - que uma dada tarefa seja cumprida.

- Por fim, as condições externas, embora nem sempre estejam sob o controle da equipe, devem estar favoráveis à execução da tarefa. Exemplos são as condições climáticas, as autorizações necessárias, o relacionamento com a vizinhança, etc. 


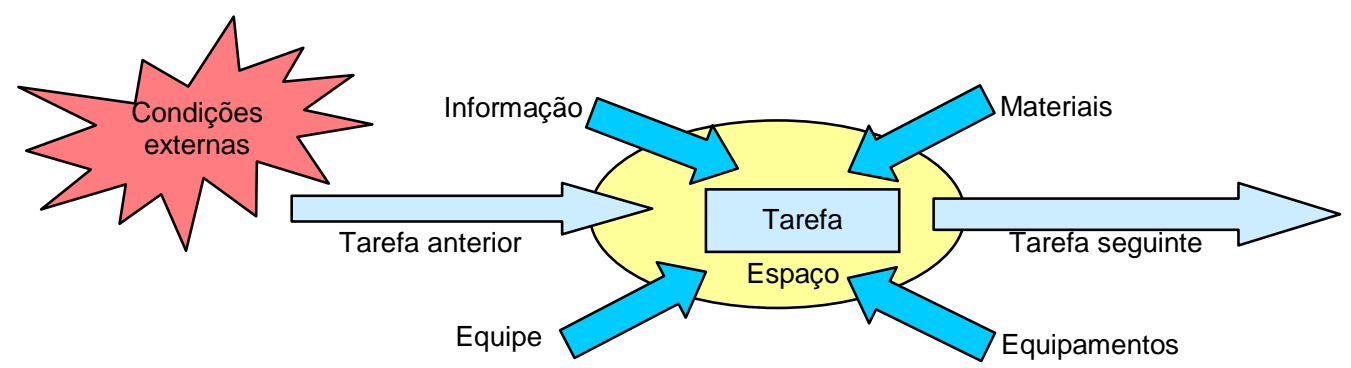

Figura 2-15 - As sete pré-condições típicas de uma tarefa de construção (BERTELSEN et al, 2007)

Koskela (1999) lembra que muitas destas pré-condições têm alta variabilidade, dadas as peculiaridades da construção, e então a probabilidade de uma delas vir a faltar é considerável. Exemplos são dados pelo próprio autor:

[...] não é incomum que projetos detalhados estejam faltando no início do trabalho. Falhas latentes em desenhos ou em peças pré-fabricadas causarão problemas de realização no local. Condições externas (temperatura extrema, chuva, neve e vento) formam uma fonte específica de variabilidade. Ainda, a produtividade dos trabalhos manuais é inerentemente variável, e a disponibilidade de espaço, liberado por outras equipes, é certamente variável [...] (KOSKELA, 1999, p. 247)

Para se ter uma idéia de como a variabilidade de cada pré-condição impacta na execução da tarefa, o autor se baseia na Lei das Operações de Montagem, de Hopp e Spearman (2001), e fornece um exemplo básico: se a probabilidade de desvio nos fluxos de cada uma das pré-condições for de 5\%, a probabilidade de não haver nenhum desvio será:

$$
\text { Prob }\{\text { Nenhum desvio em qualquer entrada }\}=(0,95)^{7} \cong 70 \%
$$

Na falta de qualquer pré-condição, o responsável pela tarefa se vê obrigado a optar entre duas alternativas, quais sejam:

- Aguardar até que todos os recursos estejam disponíveis, arcando com o desperdício de manter os demais recursos ociosos; ou

- Iniciar a tarefa em condição sub-ótima, sem a disponibilidade de todos os recursos, provocando outros desperdícios, tais como: aumento do estoque de tarefas semi-acabadas, tempo de processamento, variabilidade, defeitos e retrabalho ${ }^{7}$.

7 Koskela (2004) faz uma análise detalhada sobre a prática de iniciar uma atividade sem a disponibilidade de todos os recursos, e dá a esta prática o nome de Making-Do. 
$\mathrm{Na}$ construção de uma RDU, da mesma forma que na construção civil, a necessidade de todas as sete pré-condições deve ser satisfeita, sendo necessário o desenvolvimento de soluções de controle adequadas para evitar a espera ou execução em condição sub-ótima.

\section{Unicidade}

A segunda característica, a unicidade, é bastante discutida em diversos artigos do IGLC (KOSKELA, 1992, 1999, 2000; BALLARD; HOWELL, 1998; BERTELSEN, 2003; BERTELSEN; KOSKELA, 2004; BERTELSEN; SACKS, 2007; BERTELSEN et al., 2007). Ela está relacionada ao fato de cada projeto de construção ser único em essência, sempre com características específicas que o diferenciam dos demais. Koskela (2000) explica que a unicidade está relacionada a três fatores principais: diferentes necessidades e prioridades de cada cliente, diferentes locais e ambientes em que ocorre cada construção e diferentes visões de arquitetos e engenheiros quanto à melhor solução para cada caso.

Bertelsen et al (2007) contribuem nessa discussão explicando que a produção de elementos únicos ocorre fundamentalmente por meio de projetos, e não por meio de atividades rotineiras ${ }^{8}$, como comumente ocorre na manufatura repetitiva. $\mathrm{Na}$ produção por atividades rotineiras, as atividades de produção se mantêm padronizadas, repetindo-se ciclo a ciclo. Já na produção por projeto, ocorre o oposto: como cada produto é único, raramente ocorre de certa atividade ser executada da mesma forma uma segunda vez.

Segundo Koskela (2000), uma conseqüência de cada produto ser único é que o desenvolvimento de produto passa a ser parte integrante da produção. A Figura 2-16, baseada em Picchi (2001), mostra graficamente como esta característica diferencia a manufatura da construção. Na manufatura, um produto novo sempre passa por um fluxo de desenvolvimento, desde o conceito ao lançamento; porém, após o lançamento, a empresa pode repetir ciclos de venda e produção curtos e repetitivos, sem a necessidade de um novo desenvolvimento. Já na construção, o fluxo de desenvolvimento faz parte do fluxo de produção, sendo necessário um desenvolvimento novo para viabilizar cada novo empreendimento.

\footnotetext{
${ }^{8}$ Os termos utilizados ("projetos" e "atividades rotineiras") estão baseados em Menezes (2003).
} 

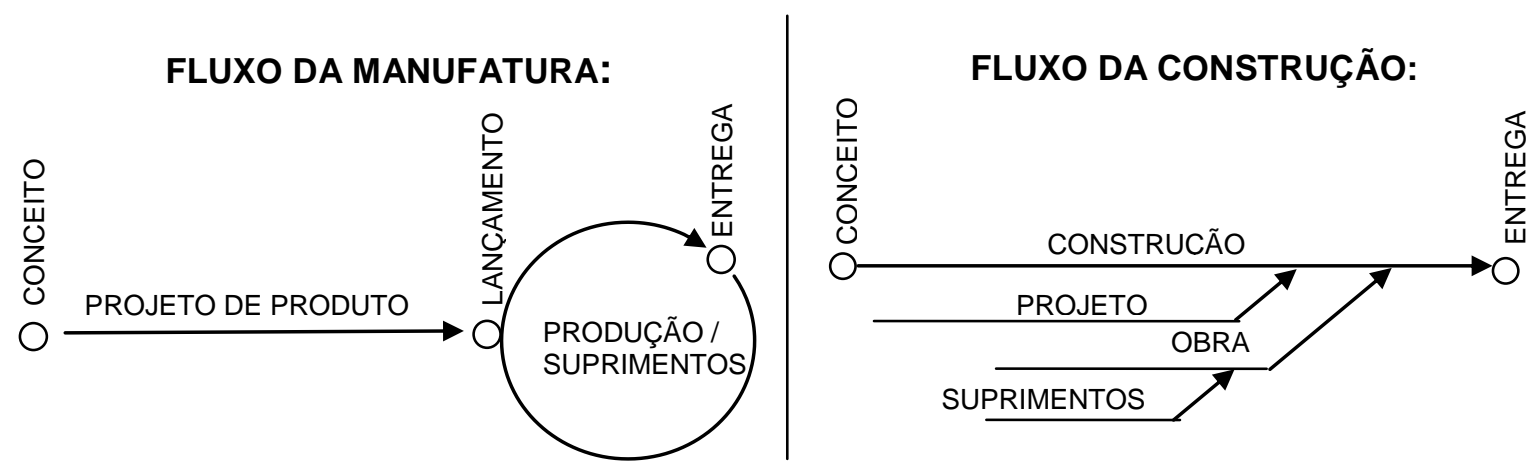

Figura 2-16 - O fluxo da manufatura e o fluxo da construção (baseada em PICCHI, 2001)

Outra conseqüência da unicidade da produção, também levantada por Koskela (2000), é a incerteza quanto à aceitação do cliente, já que não há como se fazer um protótipo antes de iniciar a produção.

Na construção de uma RDU, observa-se também o aspecto da unicidade, uma vez que um local que já dispõe da rede de certa utilidade não necessitará de outra, dado que cada cliente só necessita ser ligado uma única vez. E, embora haja similaridades entre as atividades de construção de rede em locais diferentes, sempre existirão características específicas de cada local a serem levadas em conta (relevo, geologia, clima, interferências, perfil da população, exigências de autoridades, etc.).

No entanto, as conseqüências levantadas por Koskela (2000) devem ser analisadas separadamente para o caso das RDUs. Por um lado, a necessidade de uma fase de desenvolvimento de produto para cada construção nova também é visível nas RDUs, da mesma maneira que em outras construções, já que toda rede nova precisa antes ser projetada levando em conta suas características específicas. Por outro lado, a questão da incerteza na aceitação por parte do cliente é menor: enquanto em outras construções - edifícios, por exemplo - o cliente costuma ter muitos parâmetros de avaliação ao final da obra - estrutura, acabamento, estética, etc. - numa RDU o cliente costuma aprovar o serviço ao final do mesmo, desde que a utilidade chegue à sua instalação na quantidade e qualidade adequadas.

\section{Produção em campo}

A terceira característica da construção levantada, a produção em campo, diz respeito ao fato da maior parte da produção ser executada no local final em que o produto deve ser construído, uma vez que o produto é geralmente um bem imóvel. O autor relaciona diversas conseqüências desta peculiaridade, resumidas aqui em três: 
- Espaço como recurso: o espaço é mais uma entrada necessária para a execução da produção, e sua disponibilidade deve ser cuidadosamente planejada, já que são as equipes que se movimentam, e não as peças. Assim, um problema que pode ocorrer, se o espaço não for bem planejado, é o que Koskela (2000) denomina congestionamento: diversas equipes trabalhando simultaneamente em um mesmo espaço, uma interferindo no trabalho da outra.

- Falta de proteção contra imprevistos: usualmente, existe certa incerteza quanto aos elementos externos à produção, tais como clima, trânsito, relacionamento com autoridades e vizinhança, deixando a produção vulnerável a interrupções.

- Movimentação de infra-estrutura: as pessoas e máquinas - e não só os materiais, como na manufatura - devem ser movimentados para dentro e para fora do local de trabalho, em movimentos coordenados e detalhadamente planejados.

Percebe-se, no caso da construção de uma RDU, que a questão da produção em campo não só está presente, mas também se mostra de forma mais intensa que em construções executadas em locais fixos - como edifícios, por exemplo. Isto porque, quando se constrói um edifício, as atividades podem até acontecer no campo, mas costuma haver uma área delimitada em que a construção se mantém em andamento por algum período de tempo. Já na construção de uma RDU, a maioria das atividades ocorre em vias públicas, com curta permanência da equipe em cada local. Os impactos desta peculiaridade são dados a seguir:

- A utilização do espaço como recurso se torna mais complexa, na medida em que o espaço das vias públicas geralmente não pertence à empresa distribuidora, mas ao poder público. Na construção de um edifício, assim que é comprado o terreno e obtido o alvará de construção, apenas as equipes que trabalham naquela obra precisam ser coordenadas para evitar o congestionamento. Já na construção de uma RDU, fatores externos também podem intensificar o congestionamento, tais como: veículos, pedestres e obras de terceiros. 
- Da mesma forma, os imprevistos também são mais freqüentes. Como a equipe se movimenta entre diferentes locais em curtos espaços de tempo, a quantidade de pessoas impactadas pela obra é maior. Sendo assim, as chances de haver exigências específicas de autoridades, reclamações de vizinhos e intrusões do público (tanto de forma intencional, como em roubos e sabotagens, como na forma de acidentes no local de obra ou ao redor do mesmo) também aumentam.

- A disponibilidade de infra-estrutura também se torna mais difícil, já que a movimentação de recursos não deve ocorrer somente para dentro e para fora da obra, mas ao longo da obra, uma vez que esta percorre longos trechos de rede.

\section{Organização temporária}

A quarta característica da construção, a organização temporária, refere-se à estrutura de recursos humanos típica encontrada em projetos de construção. Koskela (2000) explica que cada projeto de construção geralmente monta uma organização virtual exclusiva, contendo diferentes empresas que às vezes nunca trabalharam juntas antes, ligadas entre si por arranjos contratuais variados. A organização temporária se reflete na mão-de-obra, que pode também ser empregada exclusivamente para um determinado projeto.

Esta característica da construção pode ser vista, segundo este autor, como conseqüência de outras duas. Por um lado, a unicidade do produto faz com que se usem materiais e técnicas diferentes em cada projeto, bem como especialidades diferentes da mão-de-obra. Por outro lado, a produção em campo exige que muitas vezes, por questões econômicas, sejam usadas empresas locais para a execução das atividades.

O fato de o trabalho de construção ser executado por uma organização temporária tem claras conseqüências sobre o sistema de produção, conforme as constatações apresentadas a seguir:

- Aumenta a imprevisibilidade do sistema produtivo, impactando no aumento de sua complexidade (BERTELSEN, 2003);

- Faz com que haja uma competição por recursos entre projetos, como mostra na Figura 2-17: uma mesma equipe pode estar contratada 
simultaneamente por mais de um projeto, e distúrbios originados em um projeto são facilmente transmitidos para outros (BERTELSEN; KOSKELA, 2004; BERTELSEN; SACKS, 2007).

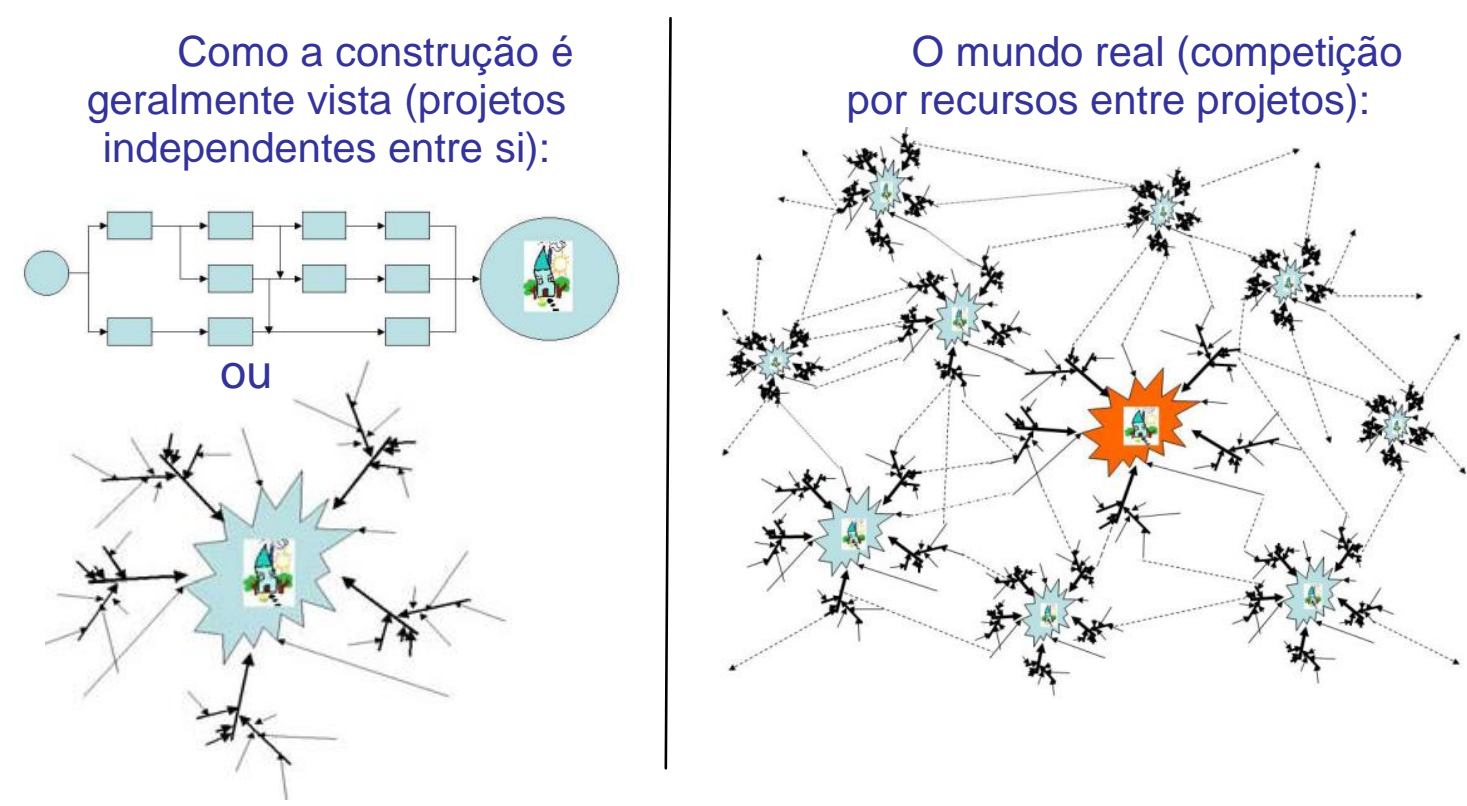

Figura 2-17 - Competição por recursos entre projetos (baseada em BERTELSEN; SACKS, 2007)

A questão da organização temporária também é observada na construção de RDU, da mesma forma que em outros tipos de construção. Como conseqüência, a imprevisibilidade do sistema produtivo e a competição por recursos entre projetos também são observadas nesse tipo de construção.

As análises feitas quanto às características do processo de construção de uma RDU estão resumidas no Quadro 2-3. 
Quadro 2-3 - Características da construção e impacto na construção de uma RDU

\begin{tabular}{|c|c|c|c|}
\hline $\begin{array}{l}\text { Característica } \\
\text { da construção } \\
\text { civil }\end{array}$ & Causa & Conseqüência & $\begin{array}{l}\text { Impacto na } \\
\text { construção de uma } \\
\text { RDU* }^{\star}\end{array}$ \\
\hline $\begin{array}{l}\text { Sete pré- } \\
\text { condições }\end{array}$ & $\begin{array}{l}\text { Necessidade de que pelo } \\
\text { menos sete pré-condições } \\
\text { sejam satisfeitas para } \\
\text { execução de cada tarefa }\end{array}$ & $\begin{array}{l}\text { Maior probabilidade de } \\
\text { não-conclusão da tarefa, } \\
\text { ou execução em } \\
\text { condições sub-ótimas. }\end{array}$ & Semelhante \\
\hline \multirow[t]{2}{*}{ Unicidade } & \multirow{2}{*}{$\begin{array}{l}\text { Diferentes necessidades } \\
\text { e prioridades de cada } \\
\text { cliente } \\
\text { - Diferentes locais e } \\
\text { ambientes } \\
\text { - Diferentes visões de } \\
\text { arquitetos e engenheiros }\end{array}$} & $\begin{array}{l}\text { Desenvolvimento de } \\
\text { produto como parte da } \\
\text { produção }\end{array}$ & Semelhante \\
\hline & & $\begin{array}{l}\text { Incerteza quanto à } \\
\text { aceitação do cliente }\end{array}$ & $\begin{array}{l}\text { Menor (número de } \\
\text { parâmetros de } \\
\text { avaliação é menor) }\end{array}$ \\
\hline \multirow[t]{3}{*}{$\begin{array}{l}\text { Produção em } \\
\text { campo }\end{array}$} & \multirow[t]{3}{*}{ Imobilidade do produto } & Espaço como recurso & $\begin{array}{l}\text { Maior (espaço } \\
\text { pertence ao poder } \\
\text { público) }\end{array}$ \\
\hline & & $\begin{array}{l}\text { Falta de proteção contra } \\
\text { imprevistos }\end{array}$ & $\begin{array}{l}\text { Maior (mais pessoas } \\
\text { são impactadas pela } \\
\text { obra) }\end{array}$ \\
\hline & & $\begin{array}{l}\text { Movimentação de infra- } \\
\text { estrutura }\end{array}$ & $\begin{array}{l}\text { Maior } \\
\text { (movimentação } \\
\text { também ao longo da } \\
\text { obra) }\end{array}$ \\
\hline \multirow[t]{2}{*}{$\begin{array}{l}\text { Organização } \\
\text { temporária }\end{array}$} & \multirow{2}{*}{$\begin{array}{l}\text { - Materiais e técnicas } \\
\text { diferentes em cada obra } \\
\text { - Uso de recursos locais }\end{array}$} & $\begin{array}{l}\text { Imprevisibilidade do } \\
\text { sistema produtivo }\end{array}$ & Semelhante \\
\hline & & $\begin{array}{l}\text { Competição de recursos } \\
\text { entre projetos }\end{array}$ & Semelhante \\
\hline
\end{tabular}

*Em comparação aos impactos na construção civil de um edifício.

\subsubsection{Características do processo de manutenção ${ }^{9}$ de uma RDU}

O processo de manutenção de uma RDU ocorre durante o período em que o consumidor usa a RDU e, para que ele possa mantê-lo, a distribuidora efetua a manutenção da mesma. Ela tem em comum com a construção de RDU o fato de as atividades serem basicamente executadas em campo. No restante, suas características são bastante diferentes, mostrando maior semelhança às características das indústrias de processo.

\section{Produção em campo}

Assim como ocorre na construção, a maioria das atividades de manutenção de RDU ocorre em vias públicas - não mais na rede sendo construída, mas na rede existente. Assim, da mesma forma que na construção, as conseqüências da

\footnotetext{
${ }^{9}$ A partir deste ponto, exceto menção em contrário, o termo "Manutenção" será usado para se referir exclusivamente à manutenção preventiva.
} 
manutenção ocorrer em campo, levantadas por Koskela (2000), são também aplicáveis:

- Espaço como recurso.

- Falta de proteção contra imprevistos.

- Movimentação de infra-estrutura.

No entanto, é necessário levar em consideração que as demais características levantadas sobre a construção de uma RDU - tarefas do tipo montagem, unicidade e organização temporária - não se aplicam da mesma forma à manutenção.

Primeiramente, as Sete Pré-Condições expostas por Koskela (2000) também são necessárias à manutenção, mas é relativamente mais fácil de assegurá-las que na construção, já que os recursos costumam ser fixos em cada processo. Sendo assim, geralmente não requerem um planejamento tão ostensivo a respeito do assunto como na construção.

Da mesma forma, a unicidade é raramente encontrada em processos de manutenção, uma vez que as manutenções preventivas podem ser executadas nos mesmos equipamentos em períodos regulares e seguindo procedimentos padronizados pré-estabelecidos (NAKAJIMA, 1989; YEOMANS; MILLINGTON, 1997; BAMBER; SHARP; HIDES, 1999; IP et al, 2000).

Por fim, a organização temporária também não costuma ocorrer para a execução da manutenção de uma RDU. Isto porque, diferentemente da construção, a manutenção não é um projeto com começo e fim estabelecidos - ela se inicia ao final da construção e não tem data de término, repetindo-se continuamente, justificando assim o estabelecimento de uma estrutura permanente.

\section{Caracterização como Indústria de processo contínuo}

Para Puttman (1991); Fransoo e Rutten (1994) e Dennis e Meredith (2000), indústrias de processo são aquelas que seguem a definição do dicionário da American Production and Inventory Control Society (APICS), apresentada a seguir:

Indústrias de processo são negócios que agregam valor aos materiais por meio da mistura, separação, formação ou reações químicas. Os processos [...] geralmente requerem um controle rígido de processo e 
um alto investimento de capital. (WALLACE ${ }^{10}, 1984$ apud FRANSOO; RUTTEN, 1994, p. 48)

Basicamente, como ressaltam Fransoo e Rutten (1994), os processos citados na definição da APICS - mistura, separação, formação e reações químicas - são geralmente executados sobre produtos não-discretos. A diferença entre estes produtos e aqueles classificados como discretos é explicada por Abdulmalek, Rajgopal e Needy (2006) no parágrafo abaixo:

Produtos discretos são aqueles que podem preservar sua forma sólida, estando ou não colocados em recipientes ou pacotes. Por outro lado, produtos não-discretos - incluindo líquidos, polpas, gases e pós podem expandir, evaporar ou secar se não forem postos em um recipiente. (ABDUMALEK; RAJGOPAL; NEEDY, 2006)

Assim, pode-se dizer que uma RDU, durante o período de distribuição e entrega da utilidade - período este em que ocorre a manutenção - se caracteriza como uma indústria de processo, uma vez que:

- O produto processado (água, energia elétrica ou gás natural) é tipicamente um produto não-discreto (ABDUMALEK; RAJGOPAL; NEEDY, 2006);

- O negócio de distribuição agrega valor ao produto, não exatamente por meio de mistura, separação, formação ou reações químicas, mas por meio de transporte (STEWART; DEWHURST, 1976; REICHHART; HOLWEG, 2007; REILLY, 2008);

- É necessário um controle rígido do processo, que geralmente utiliza sistemas de comunicação remota (SAVIC et al, 1997; IP et al, 2000);

- O investimento de capital é alto, estando entre os mais altos das empresas de serviços (KUTSCHNER; MARK, 1983; SCHMENNER, 1986).

Ashayeri, Tellen e Sellen (1996) e Crama, Pochet e Wera (2001) apresentam diversas características que, segundo eles, são típicas de indústrias de processo, e as diferenciam de manufaturas discretas. Exemplos: produto do tipo commodity (com baixa variedade, alta quantidade e baixo custo); equipamentos dedicados, com rotas fixas e pouco flexíveis; e longo tempo de setup entre dois produtos.

No entanto, há de se levar em conta - como bem enfatizam Fransoo e Rutten (1994); Abdullah (2003) e Abdulmalek, Rajgopal e Needy (2006) - que o grupo das

${ }^{10}$ WALLACE, T.F. (Ed.). APICS Dictionary. 5th ed. Falls Church, VA: American Production and Inventory Control, 1984. 
indústrias de processo não é um grupo homogêneo. Nem todas as indústrias de processo trabalham com commodities (indústrias farmacêuticas, por exemplo, podem produzir uma alta variedade de produtos em baixas quantidades e nem por isso deixam de ser indústrias de processo) assim como nem todas as manufaturas discretas têm alta variedade (indústrias de embalagens, por exemplo, costumam ter características típicas de commodities).

Sendo assim, Fransoo e Rutten (1994), também baseados na APICS, recomendam uma classificação entre as indústrias de processo, ao longo de uma dimensão determinada pelo tamanho do lote processado. Em um extremo, estão as indústrias de processo por batelada (batch/mix), que programam operações de produção de curta duração; no outro, as indústrias de processo contínuo (process/flow), que têm mínimas interrupções durante a operação de produção de cada produto ou entre produtos diferentes (Figura 2-18).

\begin{tabular}{|c|c|c|c|c|c|c|c|}
\hline \multicolumn{6}{|c|}{ Processo por Batelada } & \multicolumn{2}{|c|}{ Processo contínuo } \\
\hline 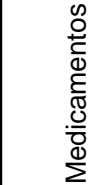 & 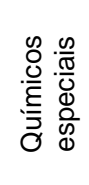 & 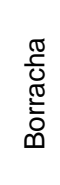 & 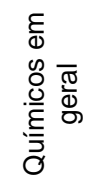 & $\begin{array}{l}\bar{\Phi} \\
\frac{\bar{\sigma}}{\overline{0}}\end{array}$ & $\begin{array}{l}\frac{8}{0} \\
\frac{\pi}{0} \\
0 \\
0\end{array}$ & 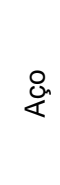 & $\frac{8}{0}$ \\
\hline
\end{tabular}

Figura 2-18 - Tipologia unidimensional para indústrias de processo (FRANSOO; RUTTEN, 1994)

Fransoo e Rutten (1994) fornecem um grupo de características que diferenciam, de forma geral, as indústrias de processo em bateladas das indústrias de processo contínuo. As características apresentadas no Quadro 2-4, no entanto, se baseiam em classificações apresentadas por Abdullah (2003); Abdulmalek, Rajgopal e Needy (2006) e Ha (2007), que são mais sucintas. Assim, as indústrias de processo contínuo são as que normalmente trabalham com produtos simples e com pouca variabilidade, mas que são produzidas em altos volumes. Os produtos geralmente passam pela mesma rota determinada, utilizando equipamentos especializados e dedicados exclusivamente ao seu processo. Já em indústrias de processo por batelada, os produtos têm uma maior variabilidade e menor volume de produção, percorrem diferentes rotas de processo e fazem uso de equipamentos do tipo multitarefa compartilhados por diversos produtos. 
Quadro 2-4 - Características de indústrias de processo contínuo e indústrias de processo por batelada (adaptado de FRANSOO; RUTTEN, 1994)

\begin{tabular}{|c|c|}
\hline Indústrias de processo por bateladas & Indústrias de processo contínuo \\
\hline Variabilidade & Invariabilidade \\
\hline Lotes pequenos & Lotes grandes \\
\hline Flexibilidade do processo & Inflexibilidade do processo \\
\hline Equipamentos multitarefa & Equipamentos especializados \\
\hline Fluxo intermitente & Fluxo contínuo \\
\hline
\end{tabular}

Nesse sentido, pode-se dizer que as RDUs, na fase em que ocorre o processo de manutenção, caracterizam-se tipicamente como indústrias de processo contínuo, tendendo a se posicionar no extremo direito da Figura 2-18:

- A variabilidade do produto de uma RDU não é só baixa, como praticamente inexistente: cada RDU lida exclusivamente com um único produto (água, gás natural ou energia elétrica).

- O volume "produzido" pela RDU é alto, distribuído em uma vasta área.

- Como conseqüência, o processo de trabalho não exige flexibilidade, já que é sempre fornecido o mesmo produto.

- Os equipamentos são dedicados e especializados para suas funções, e tendem a se manter no mesmo local durante todo seu ciclo de vida, exigindo somente manutenção.

- O fluxo é mantido contínuo ao longo de uma RDU e entre os diversos equipamentos existentes na mesma, devendo se manter ininterrupto.

As características do processo de manutenção estão resumidas no Quadro 2-5.

Quadro 2-5 - Características do processo de manutenção de uma RDU

\begin{tabular}{|c|c|c|c|}
\hline Característica & Causa & Conseqüência & $\begin{array}{l}\text { Impacto no processo de manutenção } \\
\text { de uma RDU }\end{array}$ \\
\hline \multirow[t]{3}{*}{$\begin{array}{l}\text { Produção em } \\
\text { campo }\end{array}$} & \multirow[t]{3}{*}{$\begin{array}{l}\text { Imobilidade da } \\
\text { rede }\end{array}$} & Espaço como recurso & $\begin{array}{l}\text { Maior (espaço pertence ao poder } \\
\text { público) * }\end{array}$ \\
\hline & & $\begin{array}{l}\text { Falta de proteção } \\
\text { contra imprevistos }\end{array}$ & $\begin{array}{l}\text { Maior (mais pessoas são impactadas } \\
\text { pela manutenção) }{ }^{*}\end{array}$ \\
\hline & & $\begin{array}{l}\text { Movimentação de infra- } \\
\text { estrutura }\end{array}$ & Maior (movimentação ao longo da rede) \\
\hline \multirow{5}{*}{$\begin{array}{l}\text { Indústria de } \\
\text { processo } \\
\text { contínuo }\end{array}$} & \multirow{5}{*}{$\begin{array}{l}\text { Produto não- } \\
\text { discreto de } \\
\text { pouca } \\
\text { variedade }\end{array}$} & Invariabilidade & $\begin{array}{l}\text { Maior (variabilidade é nula - produto } \\
\text { único) }{ }^{* \star}\end{array}$ \\
\hline & & Lotes grandes & $\begin{array}{l}\text { Maior (mesmo produto distribuído em } \\
\text { uma vasta área) ** }\end{array}$ \\
\hline & & $\begin{array}{l}\text { Inflexibilidade do } \\
\text { processo }\end{array}$ & Igual (processo se mantém igual) ${ }^{* *}$ \\
\hline & & $\begin{array}{l}\text { Equipamentos } \\
\text { especializados }\end{array}$ & $\begin{array}{l}\text { Igual (equipamentos mantidos sempre } \\
\text { na mesma função) ** }\end{array}$ \\
\hline & & Fluxo contínuo & $\begin{array}{l}\text { Maior (o fluxo deve se manter contínuo } \\
\text { e ininterrupto) ** }\end{array}$ \\
\hline
\end{tabular}

* Em comparação aos impactos na construção civil de um edifício.

** Em comparação aos impactos em uma planta de processo petroquímico ou siderúrgico. 


\section{A produção enxuta e extensões de sua aplicação}

Este capítulo discute os fundamentos da produção enxuta, sistema a ser considerado nesta dissertação como principal referência teórico-conceitual para balizar a busca da melhoria da produtividade em empresas de RDU.

\subsection{Histórico da produção enxuta}

O desenvolvimento da produção enxuta teve como base o Sistema Toyota de Produção (STP), desenvolvido pela Toyota Motor Company do Japão após a Segunda Guerra Mundial. Naquela época, esta empresa enfrentava condições adversas, e necessitava melhorar simultaneamente sua eficiência e flexibilidade para sobreviver no mercado japonês (WOMACK; JONES; ROOS, 1992; OHNO, 1997; LIKER, 2005). Em busca deste objetivo, um administrador da empresa, Taiichi Ohno, criou o "sistema de puxar" na fábrica, inspirado nos supermercados americanos, que levou à criação do sistema Just-In-Time (LIKER, 2005), descrito em detalhes na Seção 3.2.2. As outras técnicas contempladas ao longo desta dissertação foram sendo criadas ao longo dos anos, sempre com o propósito de eliminar os desperdícios e criar valor, e assim vieram a constituir o STP (WOMACK; JONES; ROOS, 1992; MACHADO, 2007).

No entanto, o próprio Ohno (1997) confirma que este sistema só começou a ser difundido fora dos limites da Toyota a partir de 1973, com a primeira crise do petróleo. A maior capacidade demonstrada por essa empresa para enfrentar a recessão que se seguiu chamou a atenção do governo japonês, e este tomou então a iniciativa de lançar seminários sobre o STP por todo o país.

Na década de 1990, a partir da publicação do trabalho de Womack; Jones e Roos (1992), o sistema de produção desenvolvido pela Toyota passou a ser mais amplamente conhecido como um sistema de "produção enxuta" ("lean production" ou "lean manufacturing") nas esferas acadêmica e industrial.

Liker (2005) considera que o interesse mundial atual pela produção enxuta se deve principalmente ao fato da maioria das empresas enfrentarem hoje em dia condições semelhantes àquelas enfrentadas pela Toyota nas décadas de 1940 e 
1950: a necessidade de processos rápidos e flexíveis que forneçam aos clientes o que eles desejam, quando o desejam, com o máximo de qualidade e a um custo interessante. Este autor ainda salienta que a produção enxuta difundiu-se também devido à postura da Toyota de não esconder os princípios básicos que nortearam seu sucesso, chegando inclusive a apoiar outras empresas na implantação dos mesmos.

\subsection{O pensamento enxuto e os principais elementos da produção enxuta}

O Lean Enterprise Institute (LEI, 2003) explica que o Sistema Toyota de Produção foi desenvolvido pela Toyota com o objetivo de fornecer a melhor qualidade, o menor custo e o lead time mais curto por meio da eliminação do desperdício. A busca por esse objetivo recebeu posteriormente de Womack e Jones (1996) o nome de "pensamento enxuto".

Assim, como sustentam Womack, Jones e Roos (1992); Womack e Jones (1996); LEI (2003); Ohno (1997); Liker (2005) e Dennis (2008), o coração desse sistema está na eliminação dos desperdícios identificados durante a produção, sendo desperdício entendido como qualquer atividade que consome recursos, mas não agrega valor ao cliente (LEI, 2003), ou seja, qualquer atividade que o cliente não está disposto a pagar (DENNIS, 2008).

A categorização proposta por Ohno (1988) dos sete principais tipos de desperdício encontrados em processos de produção é apresentada a seguir. Cada categoria de desperdício descrita a seguir conforme exposto pelo LEI (2003):

- Produção em excesso: produzir além das necessidades do próximo processo ou cliente.

- Espera: operadores esperando enquanto as máquinas operam, falhas no equipamento, peças necessárias que não chegam, etc.

- Transporte: movimentação desnecessária de produtos ou peças entre uma etapa e outra do processo.

- Processamento: realizar etapas desnecessárias ou incorretas, geralmente devido a equipamento ou projeto ruim.

- Estoque: possuir estoques maiores que o mínimo necessário para um sistema puxado e controlado precisamente. 
- Movimentação: operadores realizando movimentações desnecessárias tais como procurar por equipamento, peças, documentos, etc.

- Defeitos: inspeção, retrabalho e refugo devido à produção de peças defeituosas.

Alguns autores complementam a categorização proposta por Ohno (1988), indicando outros tipos de desperdício além dos sete inicialmente propostos. Liker (2005), por exemplo, inclui uma oitava categoria denominada "Desperdício da criatividade dos funcionários", referente à perda de tempo, habilidades, melhorias e oportunidades de aprendizagem que as empresas sofrem por não envolverem ou ouvirem seus funcionários. Já Emiliani (1998) inclui o "desperdício comportamental”, relacionado a comportamentos de funcionários ou grupos de funcionários que não contribuem para agregar valor. Outras opções para novas categorias de desperdício são enumeradas por Macomber e Howell (2004).

Ohno (1997) destaca que os dois pilares necessários para a sustentação do STP são:

- Just-in-time; e

- Jidoka.

Just-in-time, segundo este autor, é o sistema de produção em que as partes corretas necessárias à montagem alcançam a linha no momento em que são necessárias e somente na quantidade necessária. Uma empresa que estabeleça um fluxo que segue integralmente esse modo de operação pode chegar ao estoque zero.

Jidoka, por sua vez, significa, pelas palavras de Ohno (1997, p. 27), "dar inteligência à máquina", ou seja, instalar dispositivos que forneçam às máquinas a habilidade de detectar quando uma condição anormal ocorreu e interromper imediatamente o trabalho. Isso impede que produtos defeituosos sejam produzidos, além de fazer com que não seja mais necessário manter um operador monitorando o processo enquanto a máquina estiver funcionando normalmente.

Porém, é importante salientar, conforme concordam Ohno (1997); Liker (2005) e Dennis (2008), que o esforço de implantação da produção enxuta não se consolida enquanto os processos produtivos não se tornarem estáveis e padronizados. Um alto grau de estabilidade é necessário para que o sistema não seja constantemente 
interrompido (LIKER, 2005). Já a padronização dos processos torna as anormalidades imediatamente visíveis para que ações corretivas possam ser tomadas (DENNIS, 2008).

Por fim, todos os autores supracitados são unânimes em afirmar que os benefícios da produção enxuta só são possíveis se houver envolvimento das pessoas, ou seja, a equipe deve ser composta de membros "flexíveis e motivados, constantemente à procura de uma forma melhor de fazer as coisas" (DENNIS, 2008).

Uma maneira de apresentar em conjunto os principais elementos que constituem o sistema de produção enxuta é o modelo da Casa da Produção Enxuta, mostrada na Figura 3-1. Segundo Liker (2005), esta representação foi utilizada por Fujio Cho, discípulo de Taiichi Ohno, para auxiliar o ensino do STP à base de fornecedores da Toyota. No telhado, está o objetivo principal do sistema, que é atingir a maior qualidade possível, o menor custo possível e o lead time mais curto por meio da constante eliminação de desperdícios. Os dois pilares que sustentam o telhado são justamente aqueles destacados por Ohno (1997): Just-in-Time e Jidoka. Estes são suportados por uma base que representa a padronização e a estabilidade. No centro da casa, o envolvimento das pessoas é destacado como elemento primordial para a busca da melhoria contínua.

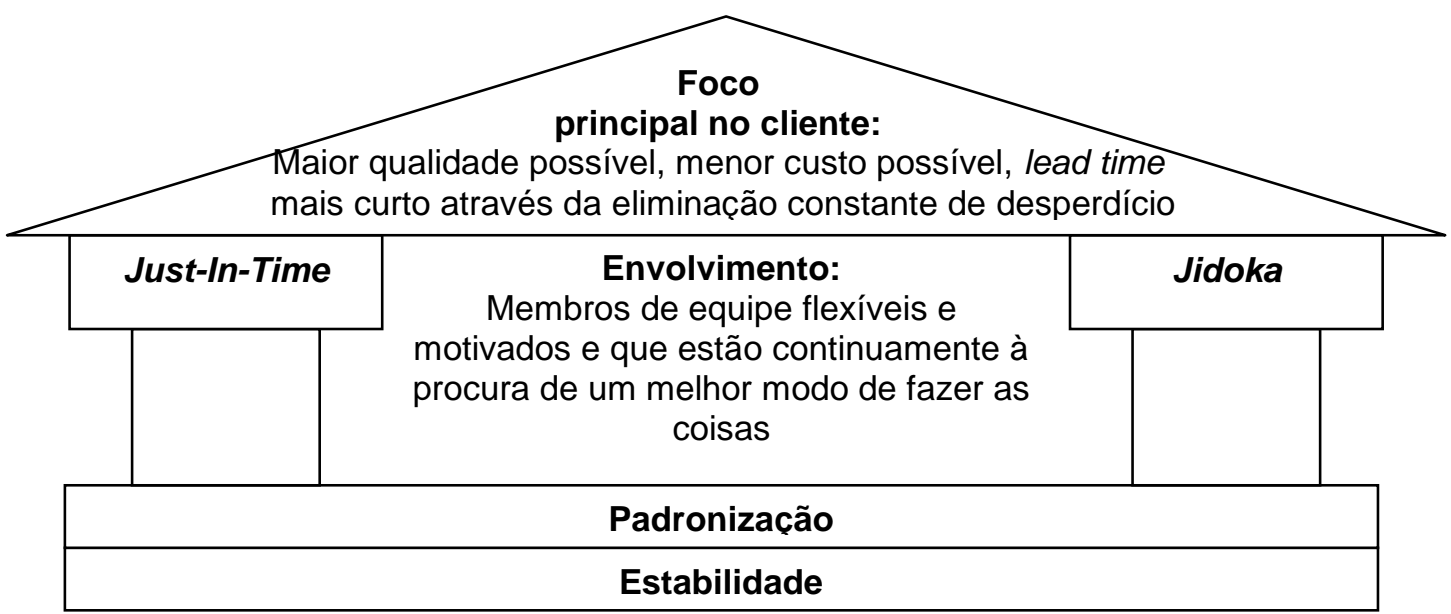

Figura 3-1 - O Modelo da Casa da Produção Enxuta (adaptada de DENNIS, 2008, p. 37) ${ }^{11}$

\footnotetext{
${ }^{11}$ Há diferentes versões da Casa da Produção Enxuta, como as expostas por Liker (2005, p. 51) e LEI (2003, p. 73), mas seus princípios fundamentais permanecem os mesmos. Neste trabalho, foi adotada a versão de Dennis (2008, p. 37), devido à forma como este autor desenvolve a relação entre os elementos nela representados e as práticas enxutas.
} 
Vale ressaltar, como lembra Liker (2005), que embora a Toyota freqüentemente enfatize as metas de qualidade, custo e lead time, sua gestão segue a prática de promover os objetivos de Qualidade, Custo, Entrega, Segurança e Moral (QCESM), que é muito comum nas empresas japonesas. Assim, segundo este autor, a empresa não admite o sacrifício da segurança e da moral de seus trabalhadores em nome da produção. Nesta dissertação, no entanto, optou-se por focar nos três primeiros objetivos (qualidade, custo e lead time), por serem mais freqüentemente associados com os resultados esperados na implementação da produção enxuta.

Segue uma descrição detalhada de cada elemento do modelo da Casa da Produção Enxuta, mostrando as principais práticas utilizadas em sua aplicação.

\subsubsection{Padronização e Estabilidade}

\section{Procedimentos habilitadores}

A padronização do trabalho é um conceito que evolui desde os tempos da produção em massa, tendo sido implantada por Henry Ford na Ford Motor Company e defendida em seu livro (FORD, 1988, p. 82) ${ }^{12}$. Para Ford, padronizar significa "escolher o melhor entre diversos métodos, e usá-lo". Somente por meio da padronização, segundo este autor, é alcançada "a união dos melhores pontos do produto com os melhores pontos da produção", e, por conseqüência, "o melhor produto pode ser produzido em quantidade suficiente e com o menor custo para 0 cliente".

Este autor ainda enfatiza que o padrão estabelecido não pode ser visto como algo imutável, sendo necessário inová-lo continuamente. Este pensamento se mostra claro no seguinte trecho de seu livro:

Se você pensar em "padronização" como o melhor que você sabe hoje, mas que será melhorado amanhã - você chegará a algum lugar. Mas se você pensar que o padrão é restritivo, o progresso pára. (FORD, 1988, p. 82)

No entanto, como descreve Liker (2005), os sucessores de Ford não seguiram este preceito, e suas empresas se tornaram burocracias coercivas, com uma rígida imposição de regras e procedimentos estabelecidos por escrito e de forma hierárquica (de cima para baixo). Isto, ao longo do tempo, gerou um sentimento

\footnotetext{
${ }^{12}$ Publicado inicialmente em 1926.
} 
negativo em relação aos padrões, vistos como estáticos, focados na eficiência, controladores dos funcionários, insensíveis às mudanças do ambiente e geralmente desagradáveis. Liker (2005) atribui a este sentimento o fato de muitas organizações modernas abandonarem os padrões e buscarem uma estrutura flexível e "orgânica", com pouca burocracia e hierarquia e maior capacitação dos funcionários para a tomada de decisões.

Ainda segundo Liker (2005), os ensinamentos da produção enxuta defendem que é possível uma organização ser ao mesmo tempo burocrática (ou seja, baseada em padrões estabelecidos) e flexível, desde que as regras e procedimentos não sejam coercivos, mas sim habilitadores - ou seja, desenvolvidos e continuamente melhorados com a participação dos próprios funcionários, como instrumentos ou ferramentas de seu trabalho diário. O Quadro 3-1, de Adler (1999) ${ }^{13}$ apud Liker (2005), explicita as diferenças entre os dois tipos de sistemas e procedimentos considerados.

Quadro 3-1 - Sistemas e padrões coercivos versus sistemas e padrões habilitadores (ADLER, 1999 apud LIKER, 2005, p. 151)

\begin{tabular}{ll}
\hline Sistemas e procedimentos coercivos & Sistemas e procedimentos habilitadores \\
\hline $\begin{array}{l}\text { Os sistemas concentram-se nos padrões de } \\
\text { desempenho para enfatizar o desempenho } \\
\text { inadequado. }\end{array}$ & $\begin{array}{l}\text { Concentram-se nos métodos de melhores } \\
\text { práticas: a informação sobre os padrões de } \\
\text { desempenho não é muito útil sem a informação } \\
\text { sobre as melhores práticas para alcançá-lo. }\end{array}$ \\
\hline $\begin{array}{l}\text { Padronizam os sistemas para minimizar os } \\
\text { custos com o cumprimento e o controle das } \\
\text { regras. }\end{array}$ & $\begin{array}{l}\text { Os sistemas devem permitir a personalização em } \\
\text { diferentes níveis de habilidade/experiência e } \\
\text { orientar a improvisação flexível. }\end{array}$ \\
\hline $\begin{array}{l}\text { Os sistemas devem ser criados para manter os os } \\
\text { funcionários fora da rede de controle. }\end{array}$ & $\begin{array}{l}\text { Os sistemas devem ajudar as pessoas a a } \\
\text { controlar seu próprio trabalho: auxiliá-las a } \\
\text { formar modelos mentais do sistema de modo } \\
\text { "transparente". }\end{array}$ \\
\hline $\begin{array}{l}\text { Os sistemas são instruções a serem seguidas, } \\
\text { não desafiadas. }\end{array}$ & $\begin{array}{l}\text { Os sistemas são modelos das melhores práticas } \\
\text { que podem ser aperfeiçoados. }\end{array}$ \\
\hline
\end{tabular}

\section{Sistema 5S}

Outra condição considerada por Dennis (2008) como necessária para se conseguir a estabilidade é que se estabeleça um senso de ordem no local de trabalho, ou seja: que o mesmo se torne livre, limpo, seguro e organizado (GALSWORTH, 2006), de modo que a situação que está fora do padrão

${ }^{13}$ ADLER, P. S. Building Better Bureaucracies. Academy of Management Executive, v. 13, n. 4, p. 36-49, 1999. 
imediatamente fique visualmente evidenciada, e os funcionários possam corrigir o problema mais facilmente (DENNIS, 2008). Neste sentido, foi desenvolvido 0 Sistema 5S.

As palavras em japonês que formam os $5 S$ - seiri, seiton, seiso, seiketsu e shitsuke - são o que Hirano (1995, p. xiii) denomina como "os cinco pilares do local de trabalho visual", pois mostram os cinco passos necessários para sua implantação:

- Separar: o primeiro passo, referente ao seiri, é separar o que é necessário para o trabalho - papéis, ferramentas, peças, etc. - daquilo que não é, e descartar aquilo que não for necessário.

- Classificar: o segundo passo, referente ao seiton, é organizar o que sobrou, definindo um lugar para cada coisa e garantindo que cada coisa permaneça em seu lugar.

- Limpar: o terceiro passo, referente ao seiso, é limpar todo o local de trabalho, deixando-o em condições adequadas de uso.

- Padronizar: o quarto passo, referente ao seiketsu, é padronizar o local, ou seja, desenvolver cartilhas para manter os três primeiros passos e impedir que se retorne à condição inicial.

- Manter: o quinto passo, referente ao shitsuke, é assegurar que o 55 crie raízes na empresa, mantendo um ambiente de trabalho estável e um processo constante de melhoria contínua.

\section{Heijunka}

Outra condição considerada para que haja estabilidade é o chamado nivelamento da produção, ou suavização da carga (heijunka). O heijunka consiste em "rebaixar os picos e elevar os vales na produção tanto quanto possível, de forma que a superfície de fluxo seja suave" (OHNO, 1997, p. 54), ou seja, manter "o volume total produzido [...] o mais constante possível" (WOMACK; JONES; ROOS, 1992, p. 145).

Segundo Liker (2005), por meio do nivelamento da carga de trabalho, busca-se impedir que ocorram problemas na produção devido a um ou mais dos seguintes fatores, conhecidos como "Três Ms": processos com nenhuma agregação de valor (Muda), sobrecarga de pessoas ou equipamentos durante o processo (Muri) ou 
desnivelamento da carga de trabalho (Mura). O LEI (2003, p. 52-53) apresenta um exemplo simples de como estes conceitos se relacionam, conforme descrito e diagramado na Figura 3-2.

Suponha que uma empresa deva transportar seis toneladas de material para seu cliente e esteja considerando algumas opções. Uma delas seria empilhar todas as seis toneladas em um caminhão e fazer uma única viagem. Contudo, isso seria muri, pois sobrecarregaria 0 caminhão (cuja capacidade de carga é de três toneladas), o que causaria quebras, o que, por sua vez, também levaria a muda e mura.

Uma segunda opção seria fazer duas viagens, uma com quatro toneladas e outra com duas. Mas isso seria mura, pois a variabilidade na quantidade de material chegando ao cliente criaria congestionamento na doca do recebimento, seguido de pouco trabalho. Esta opção também criaria muri, pois em uma das viagens o caminhão ainda estaria sobrecarregado, e muda, pois o ritmo irregular de trabalho causaria o desperdício da espera por parte dos funcionários na área de recebimento do cliente.

A terceira opção seria carregar duas toneladas no caminhão e fazer três viagens, o que seria muda, ainda que não houvesse mura e muri, pois o caminhão estaria carregado apenas parcialmente em cada uma das viagens.

O único modo de se eliminar muda, mura e muri seria carregar o caminhão com três toneladas (sua capacidade nominal) e fazer duas viagens.

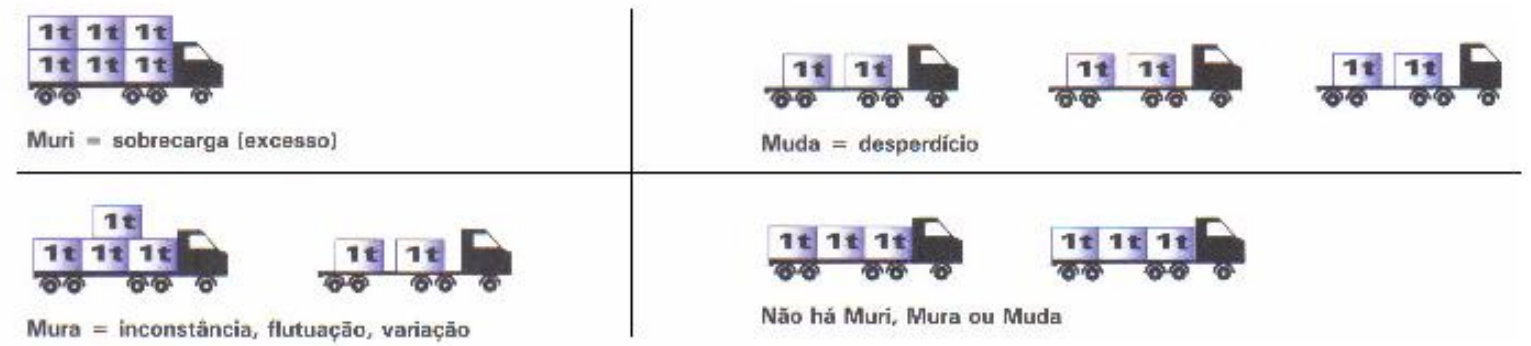

Figura 3-2 - Muri, mura e muda (LEI, 2003, p. 53)

Liker (2005) explica que, para se buscar o nivelamento da produção, é necessário que se tome o volume total de pedidos, e se nivele o mesmo para que a mesma quantidade de produtos seja produzida a cada dia.

O autor lembra, porém, que o conceito de heijunka vai além do nivelamento do volume de trabalho ao longo do tempo (nivelamento em volume), incluindo também o nivelamento da combinação de produtos a serem produzidos, ou seja, do mix de produtos (nivelamento em mix). Assim, se uma linha de produção tem três tipos de produtos a produzir, espera-se que todos os três sejam produzidos em cada período. Isso permite, entre outros benefícios, uma maior flexibilidade para fabricar o que o 
cliente realmente deseja, e assim reduzir os níveis de estoque, bem como o uso balanceado da mão-de-obra e das máquinas.

\subsubsection{Just-In-Time (JIT)}

Ohno (1997) define o Just-In-Time (JIT) como sendo o sistema de produção em que as partes corretas necessárias à montagem alcançam a linha no momento em que são necessárias e somente na quantidade necessária.

\section{Fluxo Contínuo / Takt time}

A situação ideal para que o JIT ocorra, como lembra Liker (2005), é o fluxo contínuo de peças através de uma linha de produção, em que pessoas, máquinas ou estações de trabalho são dispostas na exata seqüência de processamento, sendo cada recurso responsável por uma etapa específica de todo o trabalho (solda, montagem, embalagem, etc.). Nessa situação, como descrita por Sekine (1992), o ritmo do fluxo é determinado pelo chamado takt time, ou seja, o tempo necessário para produzir cada unidade de modo a satisfazer a demanda do cliente. Assim, se a demanda do cliente exigir que uma unidade seja produzida a cada 30 segundos, cada processo da célula deve durar os mesmos 30 segundos. Se for mais rápido, haverá superprodução; se for mais lento, a demanda do seu cliente direto - o processo seguinte - não será suprida, causando espera.

Liker (2005) lembra que o fluxo contínuo e o takt time são mais facilmente aplicados em operações repetitivas de fabricação ou de serviços, mas que, com criatividade, a consideração de tais conceitos pode ser estendida para qualquer processo passível de repetição em que os passos possam ser detalhados e as perdas possam ser identificadas para criar um fluxo melhor.

\section{Sistema puxado}

O próprio Liker (2005) lembra que nem sempre um sistema de fluxo puro é possível, ora porque os processos estão muito distantes, ora porque os tempos de ciclo para desempenhar as operações variam muito. Nestes casos, a melhor opção é o sistema puxado. Uma descrição do que vem a ser um sistema puxado, com base na diferença em relação ao sistema empurrado tradicional da produção em massa, é fornecida por Ballard (2000): 
[...] Sistemas empurrados liberam materiais ou informação em um sistema baseados em datas pré-definidas (de um programa mestre de produção, por exemplo). Sistemas puxados liberam materiais ou informação ao sistema baseados no estado do sistema (a quantidade de trabalho em processo, a qualidade dos pedidos disponíveis, etc.), além das datas pré-definidas. (BALLARD, 2000)

A forma mais comum de se operar um sistema puxado é por meio de kanbans. Segundo o LEI (2003), o kanban é um dispositivo sinalizador que autoriza e dá instruções para a produção ou para a retirada de itens em um sistema puxado.

Segundo Ohno (1997), a forma mais freqüente de kanban é um pedaço de papel dentro de um envelope de vinil retangular, contendo o número do componente de uma peça e outras informações relacionadas à sua produção. $O$ autor lembra que a idéia do kanban partiu do conceito básico do modelo operacional introduzido pelos supermercados americanos, em que um cliente pode obter (1) o que é necessário, (2) no momento em que é necessário e (3) na quantidade necessária. Assim, foi considerada a idéia de visualizar cada processo de um sistema de produção como um tipo de loja. $O$ processo seguinte (cliente) vai até o estoque produzido pelo processo anterior (supermercado) para adquirir as peças necessárias (mercadorias) no momento e na quantidade que precisa. No momento em que faz isso, ele aciona o processo anterior por meio do Kanban, para produzir e repor a quantidade recémretirada (reabastecimento de prateleiras no supermercado).

\section{Setup Rápido}

Para viabilizar a produção de produtos diferentes de forma rápida, seguindo a demanda informada por kanbans, é necessário que não se perca muito tempo no processo de preparação das máquinas entre um produto e outro (setup). Nesse sentido, foi desenvolvido por Shingo (2000) um método denominado SMED (Single Minute Exchange of Dies, ou Troca Rápida de Ferramentas), que visa à diminuição do tempo de setup para o menor possível. Para aplicação do SMED, Shingo (2000) recomenda as seguintes etapas:

- Medir o tempo total do setup no estado atual.

- Identificar os elementos internos - aqueles executados durante a parada para setup - dos externos - aqueles executados antes ou depois da parada calculando os tempos de cada um.

- Converter o máximo possível de elementos internos em externos, para que o tempo de parada seja o menor possível. 
- Reduzir o tempo dos elementos internos restantes o máximo possível.

- Reduzir também o tempo dos elementos externos.

- Padronizar o novo procedimento de setup.

Embora o termo SMED seja comumente traduzido para Troca Rápida de Ferramentas, opta-se nessa dissertação pelo uso do termo Setup Rápido, utilizado por autores brasileiros como Elias e Magalhães (2003) e Müller (2007), por sugerir uma idéia mais abrangente das possibilidades de sua aplicação.

\subsubsection{Jidoka}

A palavra Jidoka é comumente traduzida para o português como autonomação (OHNO, 1997; LEI, 2003; LIKER, 2005). Trata-se, segundo Ohno (1997), de um conceito que vai além da simples automação, sendo definido como uma automação com toque humano.

\section{Autonomação}

$\mathrm{Na}$ automação tradicional, as máquinas funcionam sozinhas uma vez que estejam ligadas; porém, como lembra Ohno (1997), o fato de uma máquina ser automática não impede que, devido a uma anormalidade, grandes quantidades de componentes defeituosos sejam produzidas e logo se acumulem. Já na autonomação, as máquinas não apenas funcionam sozinhas, mas também são capazes de detectar problemas e se desligar automaticamente na ocorrência dos mesmos, utilizando-se para tanto dos chamados dispositivos de autonomação.

Outra vantagem do uso do Jidoka, ainda segundo Ohno (1997), é a eliminação da necessidade de manter um operador monitorando a operação de uma máquina enquanto esta estiver funcionando normalmente. Então, apenas quando a máquina pára devido a uma situação anormal é que ela recebe atenção humana. Como resultado, um trabalhador passa a poder operar diversas máquinas ao mesmo tempo, agregando valor de modo mais eficiente.

Liker (2005) complementa a explicação de Ohno (1997) sobre o Jidoka, explicando que, com essa técnica, não só as máquinas podem se desligar automaticamente, mas os próprios operadores são habilitados a desligá-las quando estes detectam um problema, por meio de botões ou cordas. Em ambos os casos, quando o equipamento pára, bandeiras ou luzes, em geral acompanhadas de 
música ou de alarme, são usadas para sinalizar a necessidade de ajuda para solucionar o problema com urgência. Esse sistema de sinalização visual para pedir ajuda é chamado de andon (Figura 3-3).

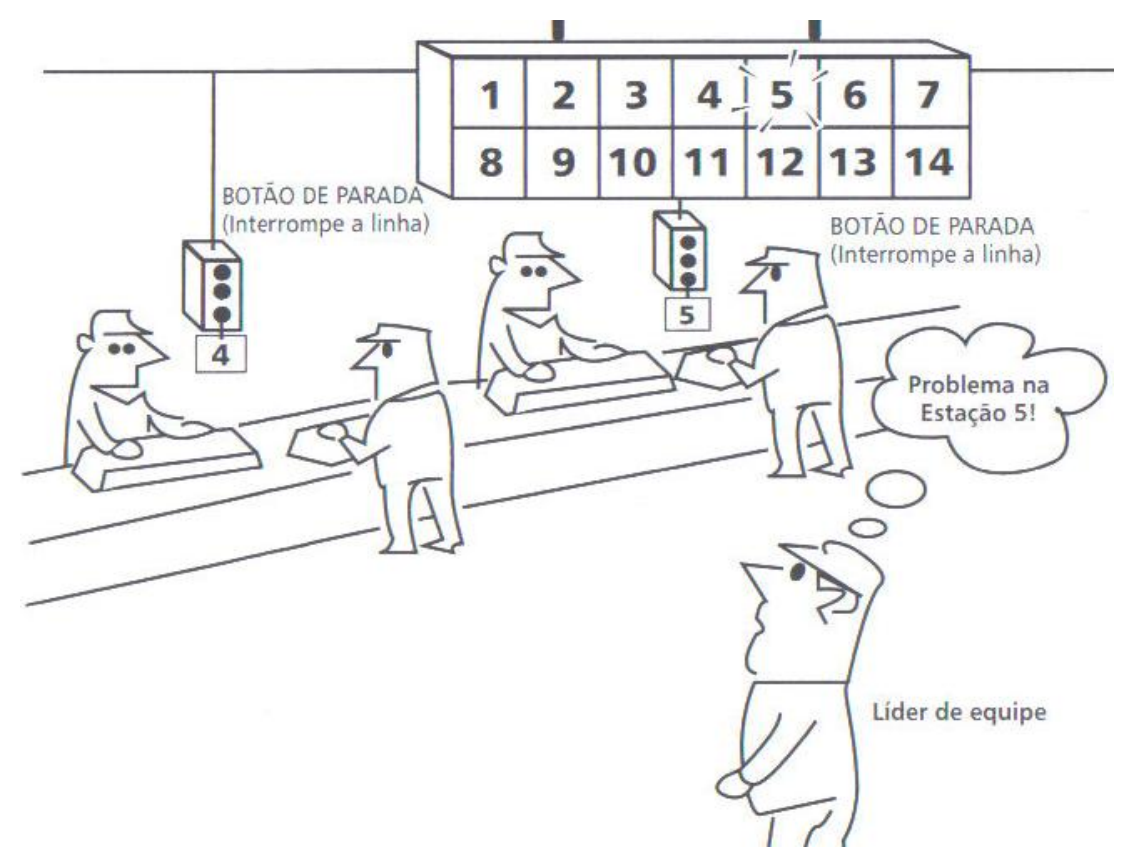

Figura 3-3 - Exemplo de sistema andon em uma linha de montagem manual (LIKER, 2005, p. 138)

\section{Poka-yoke}

Liker (2005) descreve outra prática que é, de certa maneira, associada ao Jidoka: o chamado poka-yoke ("à prova de defeitos”). A diferença é que, enquanto o Jidoka atua na detecção de problemas, o poka-yoke atua na prevenção da ocorrência dos mesmos. Os poka-yoke são métodos ou dispositivos que ajudam os operadores a evitar erros em seu trabalho, tais como escolha da peça errada, montagem incorreta de uma peça, esquecimento de um componente, etc. Exemplos comuns incluem (LEI, 2003):

- Projetos de produto com formas físicas que tornam impossível a montagem de peças de uma maneira incorreta.

- Fotocélulas acima dos contêineres das peças, a fim de evitar que um produto passe para a etapa seguinte se as mãos do operador não tiverem interrompido o facho de luz para obter as peças necessárias. 


\subsubsection{Envolvimento}

Para o sucesso da implantação da produção enxuta em uma empresa, é necessário o total comprometimento da equipe, que deve ser composta de membros "flexíveis e motivados, constantemente à procura de uma forma melhor de fazer as coisas" (DENNIS, 2008).

É importante notar que este conceito de comprometimento da equipe se contrapõe às idéias da produção em massa desenvolvidas por Taylor e Ford no início do século XX. Como contam Womack, Jones e Roos (1992), o montador da linha de produção em massa de Ford tinha apenas uma tarefa: ajustar duas porcas em dois parafusos ou, talvez, colocar uma roda em cada carro. Não tinha ele de solicitar peças, ir atrás das ferramentas, reparar seu equipamento, inspecionar a qualidade ou mesmo entender o que os operários ao seu redor estavam fazendo. A tarefa de pensar como todas essas peças iriam se juntar e o que cada montador deveria fazer era do engenheiro de produção.

Já a produção enxuta tem como aspecto essencial o trabalho em equipe, que Ohno (1997) compara ao de um time de esporte coletivo. Assim, uma equipe passa a ser responsável por todos os passos da fabricação de um produto, com todos os membros interagindo em busca desse objetivo.

\section{Solução de Problemas}

O primeiro aspecto em que se vê o trabalho em equipe na produção enxuta é na atuação da mesma quando da ocorrência de problemas que afetem a produção.

Ohno (1997) explica que, nas empresas não-enxutas, é comum que problemas sejam "resolvidos" atuando-se em sua causa imediata, por exemplo: se uma máquina parar por causa da queima de um fusível, o mesmo é trocado para que a máquina volte a funcionar, e nenhuma investigação é realizada sobre a causa fundamental daquele fusível ter queimado. Como conseqüência, o mesmo problema tende a se repetir várias vezes, afetando a produção. Pelo pensamento enxuto, no entanto, deve-se sempre utilizar a equipe para identificar a causa-raiz do problema, e atuar diretamente sobre a mesma, evitando-se assim que o problema volte a se repetir. 
Na Toyota, um método bastante utilizado para a solução de problemas é o dos Cinco Porquês. Este método consiste na prática de se perguntar "por quê?" repetidamente sempre que se encontrar um problema, a fim de ir além dos sintomas óbvios, descobrindo-se a causa-raiz, e em seguida desenvolver e implementar soluções voltadas à causa-raiz (OHNO, 1997; LEI, 2003; LIKER, 2005). Ohno (1997) fornece o seguinte exemplo de utilização desse método para o caso de uma máquina que parou de funcionar:

1. Por que a máquina parou? Porque houve uma sobrecarga e o fusível queimou.

2. Por que houve uma sobrecarga? Porque o mancal não estava suficientemente lubrificado.

3. Por que não estava suficientemente lubrificado? Porque a bomba de lubrificação não estava bombeando suficientemente.

4. Por que não estava bombeando suficientemente? Porque o eixo da bomba estava gasto e vibrando.

5. Por que o eixo estava gasto? Porque não havia uma tela acoplada e entrava limalha. (OHNO, 1997, p. 37)

Deve-se levar em conta, como salienta Liker (2005), que o importante não é exatamente a quantidade de vezes que se pergunta "por quê?", mas a preocupação com a identificação da causa-raiz do problema e posterior atuação sobre a mesma, para que não haja recorrência.

\section{Grupos kaizen}

Liker (2005) e Dennis (2008) consideram como principal diferencial do modelo Toyota a prática da melhoria contínua, ou kaizen, que remete à busca incessante de uma forma melhor de se fazer as coisas. Segundo Liker (2005), o primeiro passo para se executar um kaizen é lembrar quem é o cliente do processo, e o que ele considera como valor. Só então se torna plausível analisar o estado atual, desenvolver uma visão do futuro e implementar a solução proposta, com base nas práticas de produção enxuta. Dennis (2008) lembra que a melhor maneira de executar esta análise é em grupo, por meio da formação de grupos kaizen, que contenham os próprios funcionários que atuam na área ou processo considerado, e sejam dedicados a periodicamente executar novas melhorias.

\section{Programa de sugestão}

Outra prática que contribui para o comprometimento dos membros da equipe em busca da melhoria contínua é o programa de sugestão. Segundo Dennis (2008), 
para um programa de sugestão ser bem sucedido, o processo de envio de sugestões deve ser simples e ter regras claras, e suas tomadas de decisão devem ser rápidas e imparciais quanto à concessão de recompensas.

\subsection{Produção enxuta em áreas de suporte}

As práticas descritas na Seção 3.2 foram inicialmente desenvolvidas para a área de manufatura da Toyota, ou seja, para a área que produz os veículos a serem vendidos. Embora algumas práticas possam ser facilmente adaptadas a qualquer outra área - caso, por exemplo, do Sistema 5S e dos grupos kaizen - seu escopo de aplicação inicial foi a produção de veículos.

No entanto, ao longo dos anos, surgiu a necessidade de se desenvolver práticas específicas para racionalizar também outros processos que dão suporte à manufatura.

Um exemplo é a manutenção dos equipamentos, necessária para que estes se mantenham sempre aptos para executar as tarefas que lhes são atribuídas e evitarem paradas na produção. Neste contexto, foi desenvolvido o Total Productive Maintenance (TPM), ou Manutenção Produtiva Total, descrita na Seção 3.3.1.

Outro processo que merece destaque é o desenvolvimento de novos produtos. Neste caso, trata-se de um processo que ocorre antes do lançamento do produto, mas cujas decisões impactam significativamente nas possibilidades da produção obter uma maior qualidade, um menor preço e um menor lead time. Por este motivo, foi desenvolvida uma prática enxuta específica, denominada Set Based Concurrent Engineering (SBCE), ou Engenharia Simultânea Baseada em Pontos.

Devido à importância dos processos de manutenção e de desenvolvimento de produtos no setor de RDUs, observados na Seção 2.3.2, optou-se por incluir estas duas práticas no escopo desta dissertação. Uma maior descrição destas práticas é dada a seguir (Seções 3.3.1 e 3.3.2) 


\subsubsection{Produção enxuta na manutenção - o TPM e o TPEM}

Segundo Nakajima (1989), o objetivo do Total Productive Maintenance, ou Manutenção Produtiva Total (TPM) é garantir que as máquinas necessárias para o processo de produção estejam sempre aptas a realizar suas tarefas. O sistema do TPM engloba uma série de técnicas empregadas pioneiramente pela Denso, uma empresa do Grupo Toyota (LEI, 2003).

O TPM é descrito em detalhes por Nakajima (1989) e Shirose (1992), e consiste em envolver todos os membros da equipe na eliminação das seis grandes perdas que diminuem a eficiência das máquinas (Quadro 3-2).

Quadro 3-2 - Seis grandes perdas que diminuem a eficiência das máquinas (adaptado de NAKAJIMA, 1989)

\begin{tabular}{lll}
\hline Tipo de perda & Perda & Explicação / Exemplo \\
\hline Tempo de & Avaria de equipamento & Equipamento sem condições de uso. \\
\cline { 2 - 3 } $\begin{array}{l}\text { parada } \\
\text { Atrasos na montagem }\end{array}$ & e & $\begin{array}{l}\text { Trocas de ferramentas em prensas e em máquinas } \\
\text { nos ajustes }\end{array}$ \\
\hline $\begin{array}{l}\text { Perdas de } \\
\text { velocidade e } \\
\text { perdas ocultas }\end{array}$ & $\begin{array}{l}\text { Tempo ocioso e pequenas } \\
\text { paradas }\end{array}$ & $\begin{array}{l}\text { A máquina está funcionando, mas não há produtos } \\
\text { sendo processados. }\end{array}$ \\
\cline { 2 - 3 } & Velocidade reduzida & $\begin{array}{l}\text { A velocidade real da máquina é menor do que a } \\
\text { velocidade projetada. }\end{array}$ \\
\hline Defeitos & Defeitos de processamento & Sucata, defeitos que exigem conserto. \\
\cline { 2 - 3 } & Rendimento reduzido & $\begin{array}{l}\text { Inicialização da máquina até a produção } \\
\text { estabilizada. }\end{array}$ \\
\hline
\end{tabular}

Bamber (1999) enfatiza que a aplicação do TPM, tal qual descrita por Nakajima (1989), exige um sistema robusto de manutenção preventiva envolvendo toda a empresa, com a participação de todos os empregados. Para esta dissertação, no entanto, cabe considerar um modelo do TPM simplificado proposto por Hartmann (1992), que tem como motivação facilitar a aplicação do TPM em empresas nãojaponesas. Trata-se do TPEM (Total Productive Equipment Management, ou Manutenção Produtiva Total do Equipamento), desenvolvido por este autor como sendo uma alternativa de aplicação mais pragmática do TPM.

O TPEM foca, segundo Hartmann (1992), nas necessidades e prioridades reais do equipamento e nos trabalhadores diretamente envolvidos com o mesmo - no caso, os operadores e as equipes de manutenção - sem buscar, como no TPM japonês tradicional, que todo e qualquer trabalhador da empresa esteja envolvido no processo de assegurar as melhores condições de operação dos equipamentos. Os três pilares em que se baseia o TPEM são descritos a seguir: 
- Manutenção autônoma (TPM-AM): cria e organiza o envolvimento dos operadores no cuidado e na manutenção dos equipamentos, criando algum grau de "manutenção autônoma". Com isso, os próprios operadores se tornam responsáveis por manter seus equipamentos funcionando e acionam a equipe específica de manutenção somente em casos especiais.

- Manutenção Preventiva e Preditiva (TPM-PM): define um sistema de manutenção preventiva e preditiva considerando toda a vida útil do equipamento. Este pilar se assemelha à técnica de RCM (Reliability Centered Maintenance, ou Manutenção Centrada em Confiabilidade), descrito por Moore $(2007)^{14}$, e se baseia na confiabilidade (ou probabilidade de falha) do equipamento e no custo total para as tomadas de decisão sobre a freqüência e o escopo das manutenções a serem realizadas.

- Gestão e Melhoria do Equipamento (TPM-EM): desenvolve soluções rápidas para a melhoria do desempenho dos equipamentos, fazendo com que os mesmos exijam menos manutenções futuras. É o caso da instalação de dispositivos que, mesmo mais caros, possam diminuir ou mesmo eliminar as necessidades de manutenção em um equipamento.

\subsubsection{Produção enxuta no desenvolvimento de novos produtos - o SBCE}

O Set-Based Concurrent Engineering, ou Engenharia Simultânea Baseada em Conjuntos (SBCE) é uma prática aplicada pela Toyota derivada da adaptação da produção enxuta ao processo de desenvolvimento de novos produtos e processos. Uma descrição detalhada desta abordagem é apresentada por Ward et al (1995) e posteriormente complementada em Sobek II, Ward e Liker (1999). Womack, Jones e Roos (1992); LEI (2003) e Liker (2005) também fazem breves menções sobre o SBCE.

Para descrever o SBCE, Sobek II, Ward e Liker (1999) recorrem primeiramente a uma explicação sobre as "práticas tradicionais de desenvolvimento", representadas pelos dois processos de desenvolvimento comumente encontrados na indústria:

\footnotetext{
${ }^{14}$ Waeyenbergh e Pintelon (2002) fornecem uma análise comparativa entre o TPM, o RCM e outros conceitos descritos na literatura a respeito de manutenção.
} 
A tradicional Engenharia Serial [Baseada em Pontos] consiste em uma série de funções, cada uma desenvolvendo uma solução única ou "ponto" (parte superior da Figura 3-4). Nesta ilustração, a área de desenho industrial gera sua melhor e única solução baseada em seus próprios critérios, e "joga por cima do muro" para a área de marketing, que gera o melhor plano de marketing baseado no que o desenho industrial the entregou, e assim por diante. [...] Existem ciclos de feedback, mas o feedback das funções à jusante chega tarde, geralmente depois que as funções à montante estão comprometidas com uma solução em particular. [...]

[Já] a Engenharia Simultânea típica nos Estados Unidos é um refinamento do desenvolvimento baseado em pontos, mas ainda não quebra o paradigma [...] (parte inferior da Figura 3-4). Uma função como o desenho industrial vem com uma solução de projeto e mostra para as outras funções para comentários. Estas funções à jusante analisam e criticam o projeto sob sua perspectiva. [...] Nós a chamamos de "Engenharia Simultânea Baseada em Pontos" (SOBEK II; WARD; LIKER, 1999, p. 69)

\section{ENGENHARIA SERIAL BASEADA EM PONTOS}

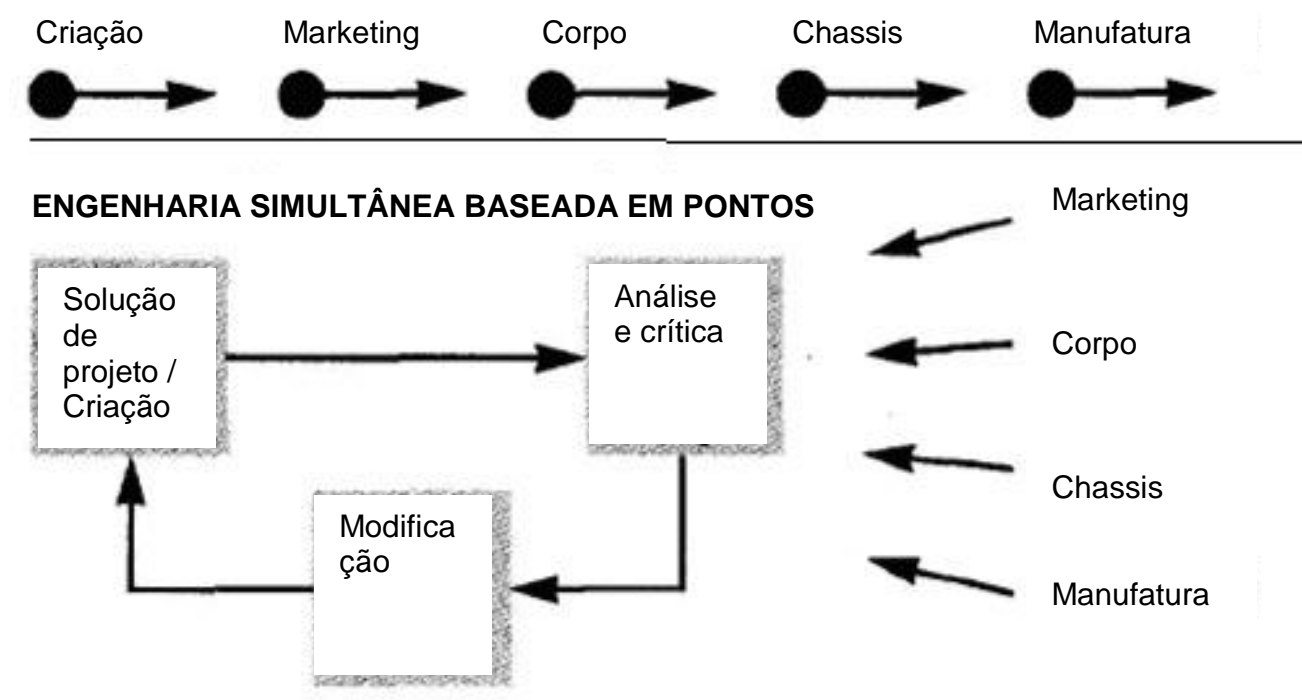

Figura 3-4 - Processos de Desenvolvimento de Produto Tradicionais Baseados em Pontos (SOBEK II; WARD; LIKER, 1999, p. 69)

Estes autores concordam que a Engenharia Simultânea Baseada em Pontos é uma evolução da Engenharia Serial Baseada em Pontos, levando-se em consideração que as mudanças de projeto se tornam mais fáceis e baratas por serem executadas com maior antecedência. Contudo, ainda que o projeto passe pela crítica sob diferenças perspectivas funcionais, qualquer mudança causa novas mudanças e análises, que resultam em retrabalho e mais demandas de comunicação. Assim, a convergência para uma solução comum se torna difícil e, por conta do prazo, acaba-se optando por uma solução sub-ótima. 
Sobek II, Ward e Liker (1999) explicam que no SBCE, no entanto, não se trabalha exclusivamente em uma solução. Os participantes pensam, desenvolvem e comunicam conjuntos de soluções paralelas e relativamente independentes. Conforme o projeto evolui, eles gradualmente estreitam seus conjuntos com base em informações adicionais provenientes do desenvolvimento, de testes, do cliente e dos conjuntos de soluções de outros participantes. Ao final, todos convergem a uma única solução comum. Ward et al (1995) explicam que o processo de consenso, embora pareça mais demorado, auxilia a ampliar a busca de soluções e, uma vez que uma solução é tomada, tem-se uma rápida implementação.

A Figura 3-5, exposta por estes autores, ilustra um exemplo deste processo. Trata-se de um exemplo simplificado, por representar a interação de somente duas áreas, Engenharia de Projeto e Engenharia de Manufatura, enquanto o processo real envolve uma grande quantidade de áreas. Contudo, esclarece como, a partir de um processo de gradual afunilamento do espaço de possíveis soluções, é possível obter um projeto mais integrado e de consenso.

Engenharia de Projeto

"Nós trouxemos vários projetos que cumprem nossos requisitos funcionais. Eles são mais ou menos assim."

"Ótimo. Vamos trabalhar nesses limites e mantê-los informados dos desenvolvimentos."

\section{"Estreitamos as} possibilidades para este conjunto, e também já incorporamos alguns detalhes."

"Isto está muito perto do nosso projeto final. Por favor, façam sua avaliação de manufatura final."
Engenharia de Manufatura

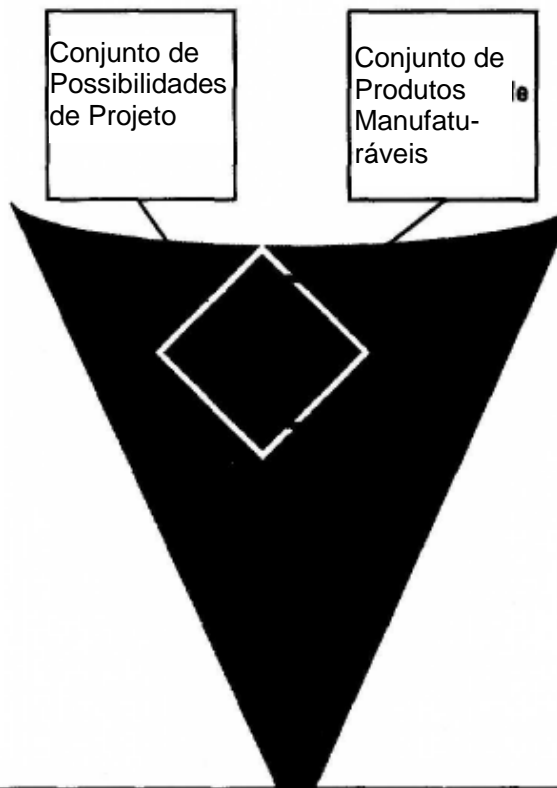

"O projeto parece bom.
"Nossas capacidades de manufaturas são melhores para projetos com estas características."

"OK. Podemos lidar com qualquer solução neste conjunto. Já temos informação suficiente para pedir aço para ferramentas e iniciar 0 planejamento do processo.

"Parece bom. Seu conjunto ainda está dentro de nossas capacidades. Temos algumas mudanças pequenas, aí podemos pedir os moldes."

A Obrigado por incluir-nos cedo. Começaremos a montar as máquinas e fabricar o lote piloto assim que possível!" 


\subsection{Produção enxuta em outros setores da economia}

Conforme descrito na Seção 1.2, o sucesso da implantação da produção enxuta na manufatura despertou o interesse de outros setores da economia, e estes, de certa forma, buscaram adaptar os conceitos enxutos a suas especificidades.

Nesta dissertação, são apresentadas duas adaptações desenvolvidas para setores específicos que, conforme visto 2.4 , apresentam alguma semelhança com pelo menos um de seus processos das RDUs abordados nesta dissertação. São eles:

- Construção civil; e

- Indústria de Processo Contínuo.

\subsubsection{Produção enxuta na construção civil - o Last Planner}

Os estudos sobre a racionalização dos processos de construção com base na produção enxuta foram impulsionados pelo trabalho publicado por Koskela (1992), que discute a possibilidade de implantação do que ele chama de "nova filosofia da produção" a este contexto específico. O autor critica o que ele denomina conceitualização tradicional da construção, ou seja, a divisão da construção em um conjunto de processos independentes com atribuição da responsabilidade por cada processo a um especialista. Tal visão, segundo ele, prejudica a gestão, na medida em que dá pouco valor ao fluxo dos processos e, por conseqüência, provoca a busca por sub-ótimos locais em detrimento ao ótimo global do processo de construção.

A partir do trabalho de Koskela (1992), teve início um movimento de adaptação da produção enxuta ao contexto da construção, considerando-se suas principais diferenças em relação à manufatura, como discutido na Seção 2.4.1. Em 1993, foi formado o International Group for Lean Construction, ou Grupo Internacional para a Construção Enxuta (IGLC), que desde então tem promovido a realização de conferências anuais sobre este tema ${ }^{15}$.

${ }^{15}$ Os trabalhos apresentados nas conferências estão disponíveis no site do IGLC ( acessado em 31/08/2008). 
Entre as propostas desenvolvidas pelos integrantes do IGLC, merece destaque o Last Planner, concebido por Ballard e Howell (BALLARD, 1994, 2000; BALLARD; HOWELL, 1998), que possibilita lidar com as particularidades da construção levantadas por Koskela $(1999,2000)$ e descritas na Seção 2.4.1. O Last Planner é elogiado e aplicado com sucesso por autores como Choo e Tommelein (2001); Nobre e Barros Neto (2003); Villas-Bôas (2004); Costa, Jungles e Oliveira (2007) e Bertelsen (2007), além do próprio Koskela $(1999,2000)$.

Segundo Ballard (2000), o desenvolvimento do Last Planner surgiu da constatação baseada em um estudo realizado por Ballard e Howell (1998), de que apenas cerca de metade das ordens passadas às equipes de construção são completadas conforme planejado. $O$ autor atribui este fato ao raciocínio tradicionalmente encontrado na indústria da construção civil, segundo o qual o trabalho a ser realizado por uma equipe deve seguir rigorosamente o cronograma do projeto. Trata-se, portanto, de um sistema "empurrado", ou seja: com base nos objetivos e na informação disponível, o planejamento decide o que deve ser feito, e cabe ao responsável pela execução correr atrás dos recursos para cumprir o solicitado. Assim, supõe-se que todos os recursos estarão disponíveis, e que tudo o que estiver planejado será devidamente executado (Figura 3-6).

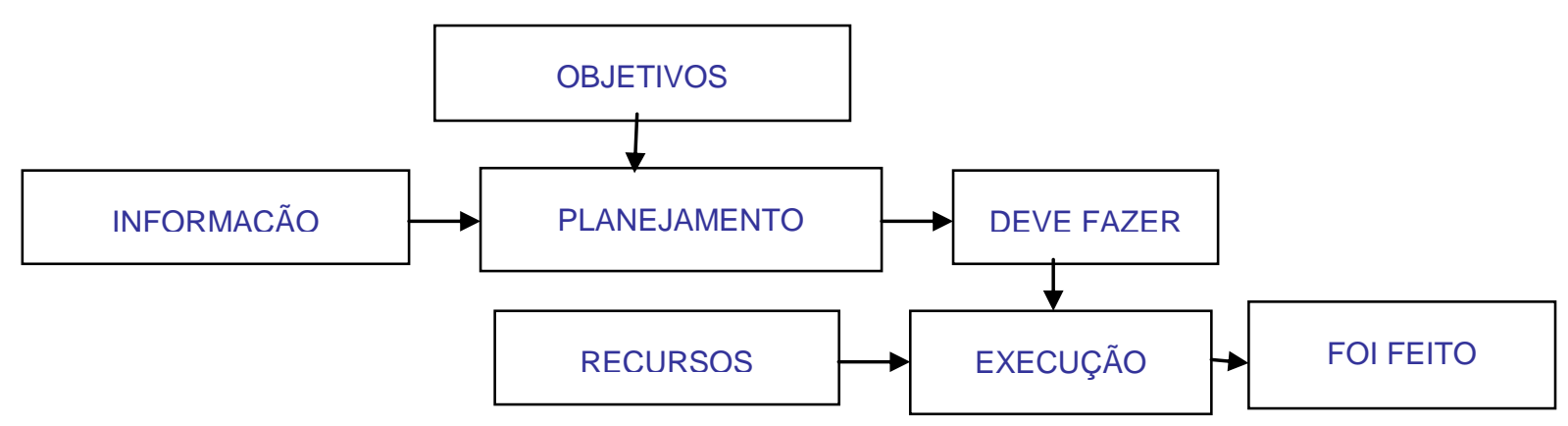

Figura 3-6 - O sistema tradicional de empurrar (adaptada de BALLARD, 2000)

A idéia do Last Planner é justamente trazer a idéia do sistema puxado, proposto por Ohno (1988), para o contexto da construção civil. Assim, os materiais e a informação entram no sistema somente se o processo for capaz de utilizá-los no trabalho.

Para explicar o Last Planner, Ballard (2000) primeiramente descreve os três níveis de planejamento geralmente encontrados em obras de construção: 
- O planejamento de longo prazo, focado em objetivos e restrições globais, governando o projeto como um todo;

- O planejamento de médio prazo, responsável por especificar maneiras de atingir estes objetivos (Lookahead); e

- O último planejamento, de curtíssimo prazo, que é feito pelo chamado Last Planner (Último Planejador), e consiste na elaboração da ordem de serviço, ou seja, na definição do que exatamente a equipe fará no dia seguinte.

A ordem de serviço do Last Planner é o último elo da cadeia de planejamento, ou seja, é ela que define a produção em si. Assim, para o sistema ser considerado puxado, Ballard (2000) propõe que o mesmo não se concentre apenas no que deve ser feito (conforme o plano geral), mas combine tais informações com o que pode ser feito (conforme as pré-condições estejam satisfeitas), e assim defina, por meio da ordem de serviço, o que realmente irá ser feito. Este modo de programação e execução, também chamado de Kit Completo por Ronen (1992) e Grosfeld-Nir e Ronen (1998), garante que nenhuma ação seja programada sem que todas as précondições estejam satisfeitas (Figura 3-7).

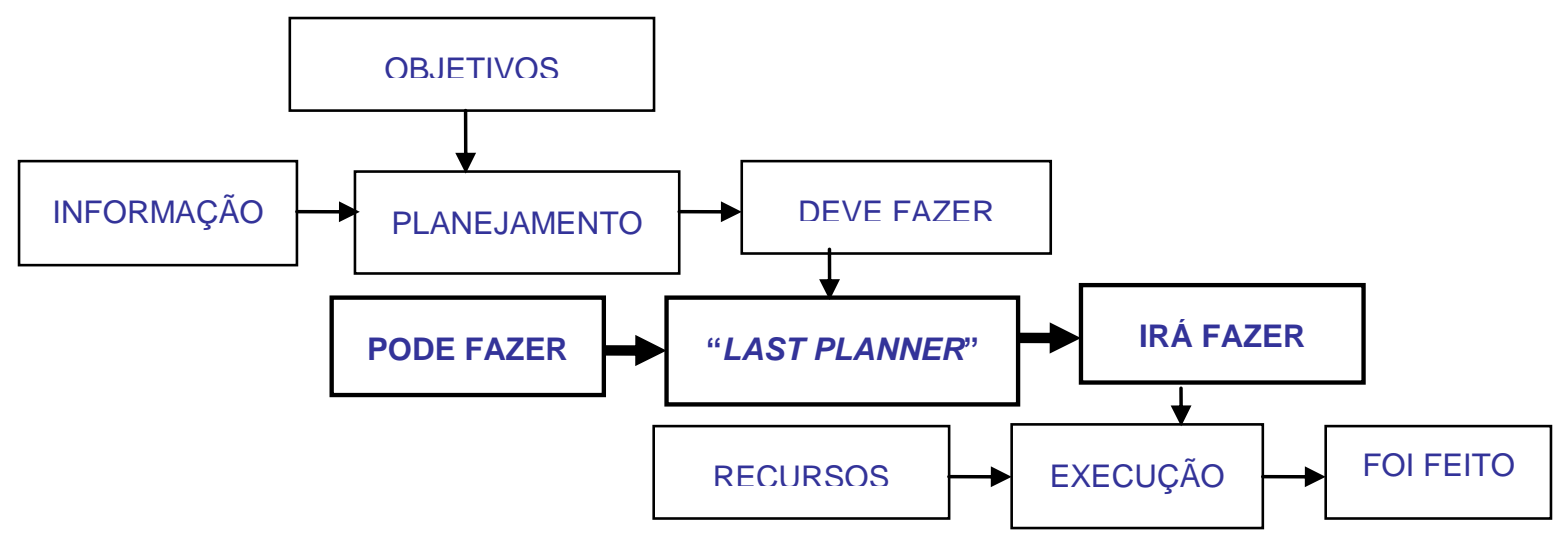

Figura 3-7 - A elaboração de ordens de serviço no Last Planner (adaptada de BALLARD, 2000, p. 3-2)

Quando o Last Planner atribui uma tarefa à equipe, ele automaticamente puxa as pré-condições para dentro do processo de execução. No entanto, para que isto seja possível, é necessário que alguém tenha previamente disponibilizado estas précondições para o Last Planner, ou seja, que tenha comprado os materiais, alocado o pessoal e equipamento necessário, reservado o espaço, etc. É nesse sentido que entra o processo à montante do Last Planner, representado pelo planejamento de médio prazo, ou Lookahead. 
O processo Lookahead está ilustrado na Figura 3-8. As tarefas potenciais são inseridas na janela de planejamento seis semanas antes da execução planejada (extremidade da direita). Então, a cada semana, o planejador revê a janela e, conforme as restrições vão sendo eliminadas, move as tarefas uma semana para a esquerda, até que elas possam entrar na Reserva de Tarefas Executáveis (Workable Backlog). Isso indica que todas as restrições foram removidas e que as tarefas estão prontas para execução.

Entrada das atividades para daqu a 6 semanas do plano geral

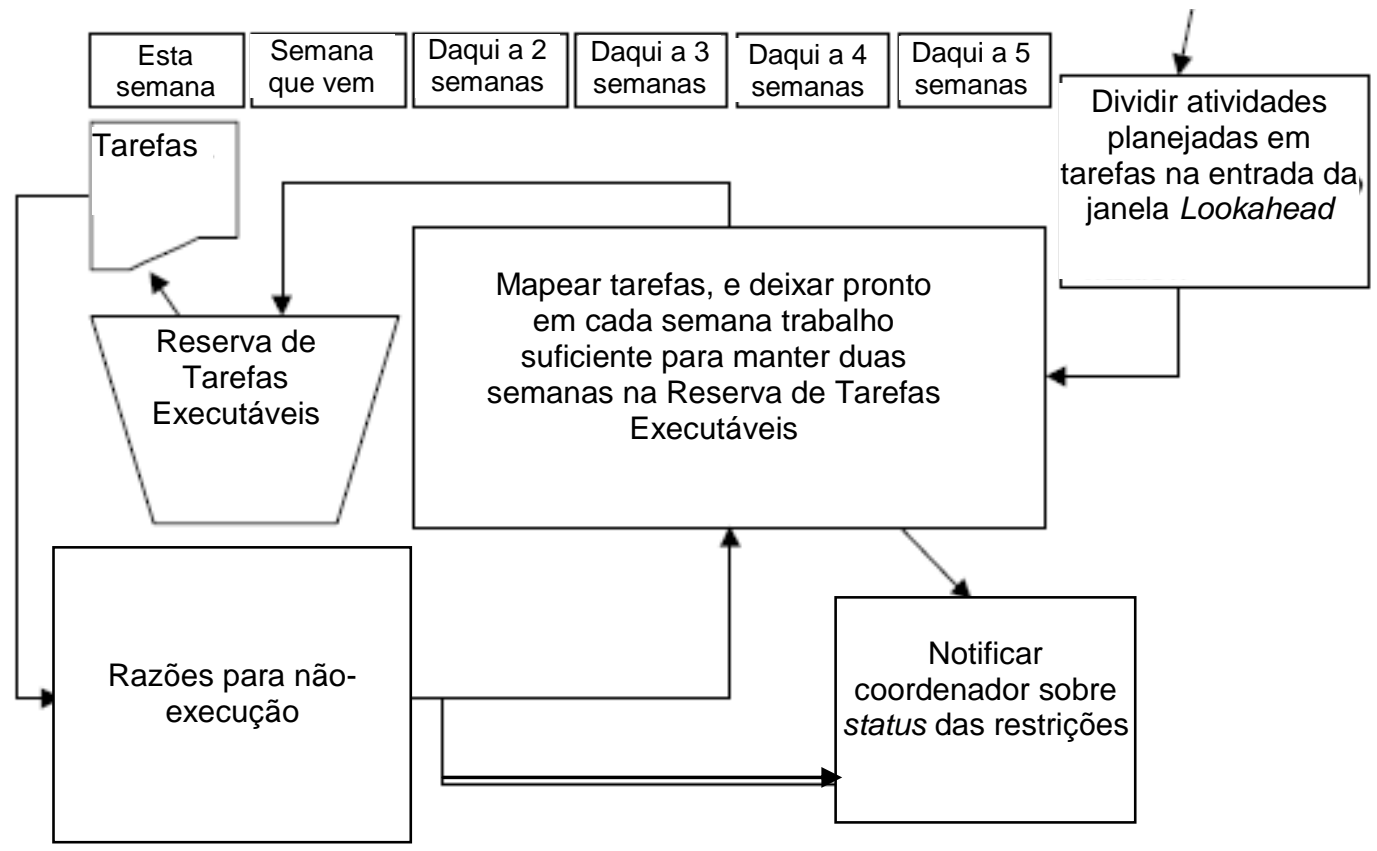

Figura 3-8 - O processo de Lookahead (adaptada de BALLARD, 2000, p. 3-10)

O instrumento de trabalho do Lookahead é uma janela de planejamento, contendo as possíveis ordens de serviço para as próximas semanas. Antes de entrar nessa janela, as atividades são detalhadas em tarefas, de forma a serem encaixadas em planos de trabalho semanais. Então cada tarefa é submetida a uma análise de restrições, de forma a definir que pré-condições são necessárias para que ela esteja pronta para execução. Com base nisso, gera-se uma lista de requisições aos fornecedores de bens e serviços, para que estes gerenciem seus processos de produção e entrega (exemplo no Quadro 3-3). 
Quadro 3-3 - Exemplo de análise de restrições no Lookahead (VILLAS-BÔAS, 2004, p. 36)

\begin{tabular}{|c|c|c|c|c|c|c|c|}
\hline \multirow{2}{*}{\multicolumn{2}{|c|}{ LISTA DE RESTRIÇÕES }} & \multirow{2}{*}{\multicolumn{2}{|c|}{ Engenheiro: }} & \multirow{2}{*}{\multicolumn{4}{|c|}{$\begin{array}{c}\text { Data Limite para a } \\
\text { Remoção das Restricões } \\
\text { Semanas } \\
\end{array}$}} \\
\hline & & & & & & & \\
\hline \multirow[t]{2}{*}{ N. } & \multirow[t]{2}{*}{ Descrição da Restrição } & \multirow[t]{2}{*}{ Responsável } & \multirow[t]{2}{*}{ Data } & $\begin{array}{c}15 / 07 \mathrm{a} \\
21 / 07\end{array}$ & $\begin{array}{c}22 / 07 \mathrm{a} \\
28 / 07\end{array}$ & $\begin{array}{c}29 / 07 \mathrm{a} \\
04 / 08\end{array}$ & $\begin{array}{c}05 / 08 \mathrm{a} \\
11 / 08\end{array}$ \\
\hline & & & & S 18 & S 19 & $\mathrm{~S} 20$ & S 21 \\
\hline \multicolumn{8}{|l|}{1} \\
\hline \multicolumn{8}{|l|}{2} \\
\hline \multicolumn{8}{|l|}{3} \\
\hline \multicolumn{8}{|l|}{4} \\
\hline 5 & & & & & & & \\
\hline 6 & & & & & & & \\
\hline
\end{tabular}

A idéia é que nenhuma tarefa entre na janela de planejamento, ou seja, movida para a esquerda na Figura 3-8 se não puder ser completada conforme planejado. Assim, se o planejador não estiver confiante que as restrições poderão ser removidas a tempo, ou no caso do surgimento de novas restrições imprevistas, a tarefa não é movida. A Reserva de Tarefas Executáveis é então repassada ao Last Planner para que este possa criar as ordens de serviço. Ballard (2000) sugere que a Reserva de Tarefas Executáveis contenha tarefas para o mínimo de duas semanas de trabalho, evitando ociosidade dos recursos no caso da ocorrência de imprevistos de última hora.

Outra peculiaridade do Last Planner está no controle de desempenho das atividades executadas, por meio da avaliação semanal do Percent Plan Complete, ou Porcentagem do Plano Completada (PPC). A cada semana, são levantadas as atividades que não chegaram a ocorrer mesmo tendo sido inseridas na Reserva de Tarefas Executáveis e são investigadas as causas de não-realização, para que medidas sejam tomadas de forma a evitar a recorrência de desvios.

O processo completo do Last Planner está esquematizado na Figura 3-9.

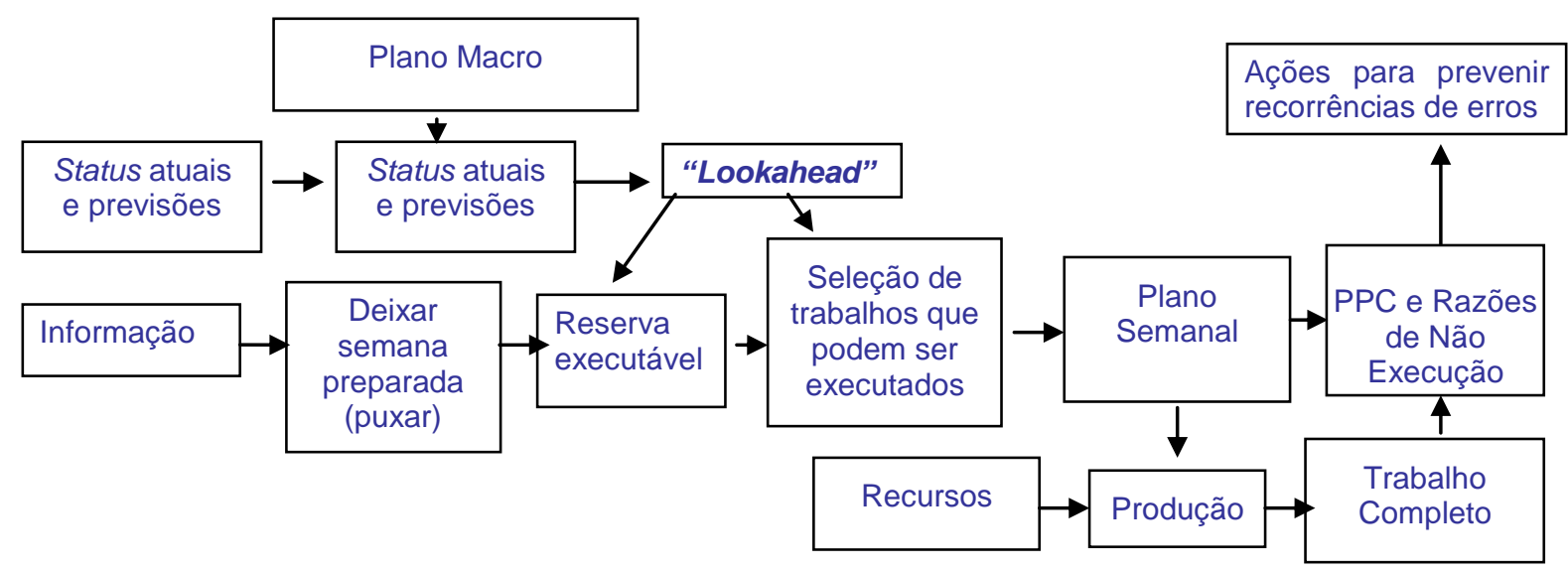

Figura 3-9 - O Sistema Last Planner completo (adaptada de BALLARD, 2000, p. 3-6) 
Koskela (1999) atribui aos seguintes cinco pilares o potencial de contribuição do Last Planner para a racionalização do processo na construção civil

1. O Kit Completo, que garante que as ordens de produção não sejam emitidas até que todos os itens necessários estejam disponíveis;

2. A medição e monitoramento do PPC (Porcentagem de Plano Completo), que diminui o risco de propagação de uma variação (desvio).

3. A investigação da não-realização, que, com remoção das causas, contribui para a busca da melhoria contínua.

4. A manutenção de uma Reserva de Tarefas Executáveis, que impede que imprevistos de última hora interrompam a produção.

5. O processo de Lookahead, que, por meio de um sistema puxado, garante que as pré-condições estejam disponíveis para cada tarefa da Reserva de Tarefas Executáveis e, ao mesmo tempo, impede que estoques excessivos de material sejam criados.

Estes pilares fazem com que o sistema seja eficiente mesmo com as particularidades da construção apresentadas na Seção 2.4.1, como mostra o Quadro 3-4.

Quadro 3-4 - Peculiaridades da construção e pilares do Last Planner

\begin{tabular}{|c|c|}
\hline Peculiaridade da construção civil & Como o Last Planner auxilia \\
\hline $\begin{array}{l}\text { Sete pré-condições (maior } \\
\text { probabilidade de não-execução da } \\
\text { tarefa, ou execução em condições } \\
\text { sub-ótimas) }\end{array}$ & $\begin{array}{l}\text { Kit Completo impede a execução em condições sub-ótimas; } \\
\text { Lookahead, PPC e investigação da não-realização diminuem } \\
\text { a probabilidade de falta de uma pré-condição. } \\
\text { Reserva de Tarefas Executáveis garante continuidade da } \\
\text { produção na falta de uma pré-condição. }\end{array}$ \\
\hline $\begin{array}{l}\text { Unicidade (desenvolvimento do } \\
\text { produto é parte da produção, e } \\
\text { existe incerteza quanto à aceitação } \\
\text { do cliente) }\end{array}$ & $\begin{array}{l}\text { Desenvolvimento do produto entra como a primeira atividade } \\
\text { no processo do Last Planner. } \\
\text { A aprovação do cliente pode ser incluída no Kit Completo, } \\
\text { quando necessária. }\end{array}$ \\
\hline $\begin{array}{l}\text { Produção em campo (espaço como } \\
\text { recurso, falta de proteção contra } \\
\text { imprevistos, movimentação da infra- } \\
\text { estrutura) }\end{array}$ & $\begin{array}{l}\text { Disponibilização do espaço é considerada uma das pré- } \\
\text { condições do Kit Completo, e entra no Lookahead. } \\
\text { Reserva de Tarefas Executáveis protege contra imprevistos. }\end{array}$ \\
\hline $\begin{array}{l}\text { Organização temporária } \\
\text { (imprevisibilidade do sistema } \\
\text { produtivo e competição por recursos } \\
\text { entre projetos) }\end{array}$ & $\begin{array}{l}\text { Reserva de Tarefas Executáveis protege contra imprevistos. } \\
P P C \text { e investigação da não-realização atuam na causa-raiz no } \\
\text { caso de falta de produção devido à competição por recursos. }\end{array}$ \\
\hline
\end{tabular}




\subsubsection{Produção enxuta na indústria de processo contínuo}

Outra forma de adaptação da produção enxuta contemplada se refere às suas possibilidades de adoção por empresas que se classificam como indústrias de processo contínuo. Conforme visto na Seção 2.4.2, para uma indústria ser considerada como de processo contínuo, não basta simplesmente que seus produtos sejam não-discretos; os mesmos ainda devem ser simples, estarem sujeitos a pouca variação e serem produzidos em grandes volumes. Tais produtos geralmente passam por uma rota bem definida, constituída de equipamentos especializados e dedicados exclusivamente ao seu processamento.

Neste contexto, o estudo de Ha (2007) pode ser tomado como um ponto de partida. Este autor argumenta que, na implantação da produção enxuta em processos contínuos, não faz sentido executar uma primeira etapa de análise do fluxo. Isto porque, diferentemente do que acontece na manufatura discreta, o fluxo já está pré-estabelecido, representado pelo próprio fluxo físico do material através dos equipamentos.

Como conseqüência, nem todos os "Sete Grandes Tipos de Desperdícios" expostos por Ohno (1997) têm no processo contínuo a mesma importância que encontram na manufatura discreta. No caso de processo contínuo, apenas os desperdícios de defeitos e de superprocessamento são realmente significantes. $O$ defeito ocorre quando o processamento não é realizado de maneira adequada, gerando produtos não-conformes ou não gerando nenhum produto, enquanto o superprocessamento ocorre quando o produto passa por etapas de que não agregam valor sob o ponto de vista do cliente.

Ha (2007) conclui, então, que o processo contínuo perfeito seria aquele em que todas as máquinas são:

- Capazes: podem produzir dentro das especificações de qualidade do cliente.

- Disponíveis: produzem sem paradas não-planejadas.

- Eficientes: consomem não mais energia e matéria-prima que o absolutamente necessário.

- Adequadas: têm capacidade suficiente para suprir a demanda.

Para este autor, as principais causas de desperdício que fazem o processo contínuo fugir desta perfeição são a condição das máquinas (sob aspectos como 
mecânica, manutenção, projeto, tecnologia, etc.) e a subotimização da sua operação em si (utilização de parâmetros de pressão, velocidade, densidade, concentração, etc. que fogem da condição ótima de operação). Para a primeira, ele recomenda um programa de manutenção de longo prazo como o TPM, descrito na Seção 3.3.1. Para a segunda, ele recomenda a utilização de uma metodologia para solução de problemas, como é o caso dos Cinco Porquês ${ }^{16}$, descritos na Seção 3.2.4.

Abdulmalek, Rajgopal e Needy (2006) chegam à mesma conclusão, quando comparam a indústria de processo contínuo com a indústria de processo em batelada e verificam que, em indústrias de processo contínuo, o TPM tem maior aplicabilidade, e, conseqüentemente maior importância que as práticas de JIT descritas na Seção 3.2.2:

[...] indústrias com baixa variedade e alto volume [...] por natureza fazem com que seu processo flua de forma contínua; no entanto, seria difícil para essas indústrias rearranjarem seus equipamentos de forma celular. Também não é realístico introduzir sistemas puxados de kanban neste ambiente. Ainda, redução de setup pode não ser crítico nestas indústrias devido aos equipamentos dedicados, altos volumes e baixa variedade; porém, nessas indústrias, o fato de os produtos fluírem de forma contínua faz com que a necessidade de TPM seja mais importante, de forma a manter alta a confiabilidade do equipamento. (ABDULMALEK; RAJGOPAL; NEEDY, 2006, p. 22)

As principais conclusões de Abdulmalek, Rajgopal e Needy (2006) sobre a aplicabilidade de práticas enxutas em indústrias de processo são resumidas na Figura 3-10.

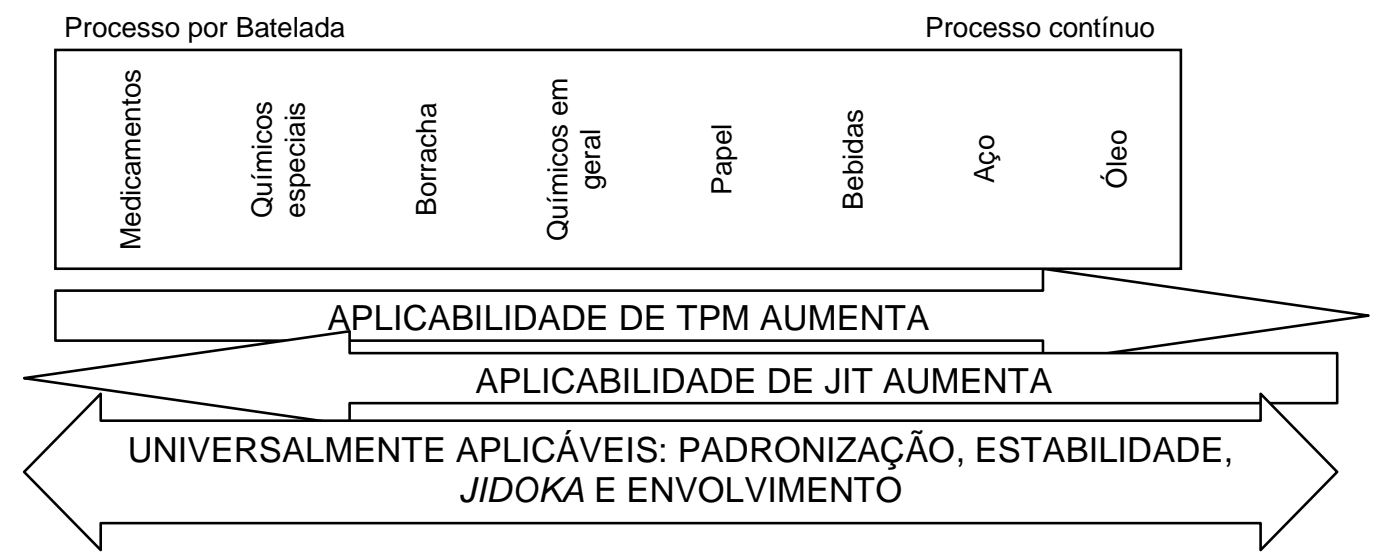

Figura 3-10 - Guia geral para aplicação de práticas enxutas em indústrias de processo (baseada em ABDUMALEK; RAJGOPAL; NEEDY, 2006, p. 23)

${ }^{16} \mathrm{Ha}$ (2007) recomenda o Seis Sigma, e não o Cinco Porquês, como metodologia para a solução de problemas. Neste trabalho, no entanto, opta-se por citar o Cinco Porquês para manter a coerência de examinar somente a aplicação de ferramentas consideradas na produção enxuta. 


\subsection{Conjunto das práticas enxutas consideradas na pesquisa}

Ao longo deste capítulo, foram abordadas diversas práticas da produção enxuta que podem, de certa maneira, auxiliar as RDUs na eliminação de desperdícios, contribuindo assim para a busca dos objetivos da produção enxuta: maior qualidade, menor custo e lead time mais curto.

Primeiramente, na Seção 3.2, foram mostradas as práticas desenvolvidas pela manufatura da Toyota, depois aplicadas - com ou sem adaptação - em diversas outras realidades. Já a Seção 3.3 apresentou práticas específicas, não de processos de manufatura, mas de outros processos existentes em uma fábrica, com destaque para a manutenção e o desenvolvimento de novos produtos. Estes processos também podem ser encontrados na maioria das empresas não-manufatureiras, como é caso das empresas de RDU. Por fim, na Seção 3.4, foram descritas aplicações da produção enxuta em setores específicos que, de uma forma ou de outra, apresentam características semelhantes a pelo menos um dos processos que constituem uma RDU: construção civil e indústria de processo contínuo.

O Quadro 3-5 mostra, de forma esquemática, o conjunto de todas as práticas da produção enxuta apresentadas, devidamente divididas em subconjuntos, conforme descrito a seguir:

- Para as práticas enxutas desenvolvidas pela manufatura da Toyota, os subconjuntos são os próprios elementos do modelo da Casa da Produção Enxuta descritos nas Seções 3.2.1 a 3.2.4 (Padronização e Estabilidade, Just-In-Time, Jidoka e Envolvimento).

- O TPEM e o Last Planner, devido à sua maior abrangência, foram considerados como subconjuntos e desmembrados em seus respectivos pilares, conforme as Seções 3.3.1 e 3.4.1, sendo cada pilar considerado uma prática enxuta específica. No caso do Last Planner, apenas quatro dos cinco pilares foram considerados, uma vez que o pilar de investigação $e$ remoção das causas de não-realização das atividades não foi incluído por ser um caso especial da prática enxuta de Solução de Problemas, já abordada no subconjunto Envolvimento. 
- O SBCE descrito na Seção 3.3.2, por não se encaixar em outro subconjunto e não ter uma abrangência que justificasse um desmembramento, foi considerado um subconjunto à parte com uma única prática de mesmo nome.

Vale lembrar que na Seção 3.4.2, que trata da produção enxuta na indústria de processo contínuo, não foram mencionadas novas práticas que não tivessem sido citadas anteriormente. Naquela seção, apenas discutiu-se a aplicabilidade em novos ambientes de práticas já mencionadas, não gerando novas inclusões ao Quadro 3-5.

Para esclarecer a relação de cada prática com o pensamento enxuto, o Quadro 3-5 descreve os desperdícios evitados na sua aplicação, os objetivos da produção enxuta a eles relacionados (qualidade, custo e/ou lead time ${ }^{17}$ ), e a referências encontradas na literatura sobre sua conceituação e/ou aplicação. Algumas práticas ajudam a promover a busca dos três objetivos. O Sistema 5S, por exemplo, contribui para que se evidencie qualquer situação fora do padrão, independentemente desta ser relacionada à qualidade, custo ou lead time. Outras são mais diretamente voltadas a somente um ou dois objetivos. O Setup Rápido, por exemplo, diminui o lead time de entrega, mas não impacta, de forma direta, na qualidade ou no custo do produto fornecido.

Vale observar que a magnitude dos benefícios ou impactos que a produção enxuta como um todo pode proporcionar varia bastante na busca destes três objetivos, tendendo a ser mais efetiva em esforços de redução de custos e de lead time - diretamente obtidos pela eliminação dos desperdícios - que na melhoria da qualidade. George (2004) e Bendell (2005) explicam que a produção enxuta não possui ferramentas poderosas para reduzir variação e estabelecer um processo sob controle estatístico. Arnheiter e Maleyeff (2005, p. 13) acrescentam que "organizações enxutas deveriam fazer mais uso de dados para tomada de decisão e usar metodologias que promovem uma abordagem mais científica para a qualidade"18.

17 Conforme visto na Seção 3.2, o foco dessa dissertação se mantém nestes três objetivos. Outros itens abordados pela Toyota, como a segurança e a moral, não são considerados.

${ }^{18}$ Os três textos referenciados neste parágrafo defendem a implantação conjunta da produção enxuta com o Seis Sigma, sistema cujo foco está mais voltado para a melhoria da qualidade por meio do controle da variação. Este assunto, no entanto, não faz parte do escopo dessa dissertação. 
Outro ponto importante é que o fato de uma prática servir mais diretamente à busca de somente um ou dois objetivos não significa que ela não possa contribuir também para os demais. Como bem ressaltam Gummesson (1991) e George (2004), estes três objetivos estão diretamente ligados entre si:

Qualidade, produtividade e lucratividade são um tripé - separar um do outro cria uma família infeliz. (GUMMESSON, 1991, p. 6).

[...] você não pode alcançar a velocidade máxima [ou lead time mínimo] sem também melhorar a qualidade, nem pode alcançar a qualidade máxima sem também melhorar a velocidade. E você não pode maximizar $\mathrm{ROIC}^{19}$ [por meio da minimização do custo] sem fazer as duas coisas. (GEORGE, 2004, p. 29).

De qualquer forma, a proposta do Quadro 3-5 é de apresentar os objetivos que se mostram mais diretamente envolvidos na aplicação de cada prática enxuta.

${ }^{19}$ Return Over Invested Capital, ou Retorno Sobre Capital Investido. 
Quadro 3-5 - Práticas da produção enxuta, desperdícios e objetivos

\begin{tabular}{|c|c|c|c|c|c|c|}
\hline \multirow[b]{2}{*}{$\frac{8}{\frac{0}{\pi}}$} & \multirow[t]{2}{*}{ Nome } & \multirow[t]{2}{*}{ No que consiste } & \multirow[t]{2}{*}{$\begin{array}{l}\text { Como evita } \\
\text { desperdícios }\end{array}$} & \multicolumn{2}{|c|}{$\begin{array}{l}\text { Obje- } \\
\text { tivos }\end{array}$} & \multirow[t]{2}{*}{ Referências } \\
\hline & & & & $\begin{array}{l}\frac{0}{0} \\
\frac{\pi}{0} \\
\frac{0}{\overline{0}} \\
0\end{array}$ & 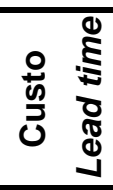 & \\
\hline \multicolumn{7}{|c|}{ Padronização e Estabilidade } \\
\hline 1 & $\begin{array}{l}\text { Procedimentos } \\
\text { habilitadores }\end{array}$ & $\begin{array}{l}\text { Procedimentos simples, } \\
\text { claros e visuais, } \\
\text { desenvolvidos e } \\
\text { continuamente } \\
\text { melhorados pelos } \\
\text { próprios funcionários. }\end{array}$ & $\begin{array}{l}\text { Evita que a } \\
\text { dificuldade de } \\
\text { entender os padrões } \\
\text { impacte na execução } \\
\text { da tarefa de maneira } \\
\text { não-ótima. }\end{array}$ & $\mathrm{X}$ & $\mathrm{X} X$ & $\mathrm{a}, \mathrm{m}, \mathrm{z}, \mathrm{ah}$ \\
\hline 2 & Sistema 5S & $\begin{array}{l}\text { Ordem visual no local de } \\
\text { trabalho: um lugar para } \\
\text { cada coisa, e cada coisa } \\
\text { no seu lugar. }\end{array}$ & $\begin{array}{l}\text { Com a ordem visual, } \\
\text { a situação fora do } \\
\text { padrão fica } \\
\text { imediatamente } \\
\text { evidenciada. }\end{array}$ & $\mathrm{X}$ & $\mathrm{X} X$ & $\mathrm{j}, \mathrm{ab}, \mathrm{ah}$ \\
\hline 3 & Heijunka & $\begin{array}{l}\text { Nivelamento da } \\
\text { produção de modo que a } \\
\text { mesma quantidade e } \\
\text { combinação de tarefas } \\
\text { sejam produzidas a cada } \\
\text { período. }\end{array}$ & $\begin{array}{l}\text { Evita sobrecarga nos } \\
\text { períodos de "pico" e } \\
\text { ociosidade nos } \\
\text { períodos de "vale", } \\
\text { além de aumentar a } \\
\text { flexibilidade da } \\
\text { produção. }\end{array}$ & $\mathrm{X}$ & $\mathrm{X} x$ & $h, m, x, z$ \\
\hline \multicolumn{7}{|c|}{ Just-In-Time } \\
\hline 4 & Fluxo contínuo & $\begin{array}{l}\text { Organização das etapas } \\
\text { de trabalho de forma a } \\
\text { identificar e eliminar as } \\
\text { perdas, criar fluxo e } \\
\text { estabelecer um ritmo } \\
\text { adequado. }\end{array}$ & $\begin{array}{l}\text { Elimina a } \\
\text { superprodução e os } \\
\text { estoques } \\
\text { intermediários. }\end{array}$ & & $\mathrm{X} X$ & $f, z$ \\
\hline 5 & Sistema puxado & $\begin{array}{l}\text { Sistema em que a } \\
\text { produção de uma etapa } \\
\text { só é iniciada quando a } \\
\text { estação seguinte } \\
\text { (cliente) indica a } \\
\text { necessidade. }\end{array}$ & $\begin{array}{l}\text { Diminui a } \\
\text { superprodução e os } \\
\text { estoques } \\
\text { intermediários nos } \\
\text { casos em que o fluxo } \\
\text { contínuo não é viável. }\end{array}$ & & $\mathrm{X} X$ & $\mathrm{~m}, \mathrm{r}, \mathrm{x}, \mathrm{z}$ \\
\hline 6 & Setup Rápido & $\begin{array}{l}\text { Análise do processo de } \\
\text { setup entre diferentes } \\
\text { lotes de trabalho, para } \\
\text { que o menor tempo } \\
\text { possível seja gasto } \\
\text { nesta mudança }\end{array}$ & $\begin{array}{l}\text { Viabiliza a execução } \\
\text { de pequenos lotes } \\
\text { para a prática do } \\
\text { heijunka e mantém o } \\
\text { equipamento } \\
\text { funcionando por mais } \\
\text { tempo. }\end{array}$ & & $\mathrm{X}$ & $\mathrm{s}, \mathrm{v}, \mathrm{ag}$ \\
\hline \multicolumn{7}{|c|}{ Jidoka } \\
\hline 7 & Autonomação & $\begin{array}{l}\text { Instalação de } \\
\text { dispositivos capazes de } \\
\text { desligar as máquinas na } \\
\text { ocorrência de } \\
\text { problemas. }\end{array}$ & $\begin{array}{l}\text { Evita que uma falha } \\
\text { se propague, gerando } \\
\text { peças defeituosas. } \\
\text { Separa o trabalho do } \\
\text { operador da máquina, } \\
\text { liberando-o para } \\
\text { outras tarefas. }\end{array}$ & $\mathrm{X}$ & $\bar{X}$ & $\mathrm{~m}, \mathrm{z}$ \\
\hline 8 & Poka-yoke & $\begin{array}{l}\text { Dispositivos que ajudam } \\
\text { os operadores a evitar } \\
\text { erros no seu trabalho. }\end{array}$ & $\begin{array}{l}\text { Evita que, por um erro } \\
\text { do operador, um } \\
\text { componente } \\
\text { apresente defeito. }\end{array}$ & $\bar{x}$ & & $w, z$ \\
\hline
\end{tabular}




\begin{tabular}{|c|c|c|c|c|c|c|c|}
\hline \multirow[b]{2}{*}{$\frac{\pi}{0.0}$} & \multirow[t]{2}{*}{ Nome } & \multirow[t]{2}{*}{ No que consiste } & \multirow[t]{2}{*}{$\begin{array}{l}\text { Como evita } \\
\text { desperdícios }\end{array}$} & \multicolumn{3}{|c|}{$\begin{array}{l}\text { Obje- } \\
\text { tivos }\end{array}$} & \multirow[t]{2}{*}{ Referências } \\
\hline & & & & $\begin{array}{l}\frac{0}{0} \\
\frac{\pi}{0} \\
\frac{0}{\sigma} \\
\frac{0}{2}\end{array}$ & $\stackrel{\circ}{\stackrel{9}{0}}$ & 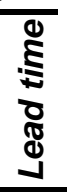 & \\
\hline \multicolumn{8}{|c|}{$\begin{array}{r}\text { Envolvimento } \\
\end{array}$} \\
\hline 9 & $\begin{array}{l}\text { Solução de } \\
\text { Problemas }\end{array}$ & $\begin{array}{l}\text { Processo de solução de } \\
\text { problemas de produção, } \\
\text { com análise e atuação } \\
\text { até a causa raiz. }\end{array}$ & $\begin{array}{l}\text { Possibilita que se } \\
\text { encontre a causa raiz } \\
\text { do problema, indo } \\
\text { além dos sintomas } \\
\text { óbvios. }\end{array}$ & $\bar{X}$ & $\bar{X}$ & $X$ & $\mathrm{~m}, \mathrm{w}, \mathrm{z}$ \\
\hline 10 & Grupos kaizen & $\begin{array}{l}\text { Engajamento num } \\
\text { esforço constante de } \\
\text { identificação de } \\
\text { oportunidades de } \\
\text { melhoria num } \\
\text { determinado processo } \\
\text { de trabalho }\end{array}$ & $\begin{array}{l}\text { Analisa o processo } \\
\text { para identificar } \\
\text { desperdícios e buscar } \\
\text { sua eliminação. }\end{array}$ & $\mathrm{X}$ & $\mathrm{X}$ & $\mathrm{X}$ & $\mathrm{h}, \mathrm{z}, \mathrm{ah}$ \\
\hline 11 & $\begin{array}{l}\text { Programa de } \\
\text { Sugestão }\end{array}$ & $\begin{array}{l}\text { Processo de envio de } \\
\text { sugestões pelos } \\
\text { funcionários, de forma } \\
\text { simples e com regras } \\
\text { claras. }\end{array}$ & $\begin{array}{l}\text { Evita o desperdício da } \\
\text { criatividade dos } \\
\text { funcionários na } \\
\text { obtenção das } \\
\text { melhores soluções. }\end{array}$ & $\bar{X}$ & $\bar{X}$ & $\bar{X}$ & ah \\
\hline \multicolumn{8}{|c|}{ TPEM } \\
\hline 12 & $\begin{array}{c}\text { TPM-AM } \\
\text { (Manutenção } \\
\text { autônoma) }\end{array}$ & $\begin{array}{l}\text { Envolvimento dos } \\
\text { operadores no cuidado e } \\
\text { manutenção diária dos } \\
\text { equipamentos. }\end{array}$ & $\begin{array}{l}\text { Garante o bom uso } \\
\text { do equipamento, e } \\
\text { libera a equipe de } \\
\text { manutenção para } \\
\text { tarefas mais } \\
\text { complexas }\end{array}$ & & & $\mathrm{X}$ & $\begin{array}{c}\mathrm{b}, \mathrm{c}, \mathrm{g}, \mathrm{n}, \mathrm{u}, \\
\mathrm{w}, \mathrm{aa}, \mathrm{ae}\end{array}$ \\
\hline 13 & $\begin{array}{c}\text { TPM-PM } \\
\text { (Manutenção } \\
\text { Preventiva e } \\
\text { Preditiva) }\end{array}$ & $\begin{array}{l}\text { Sistema de manutenção } \\
\text { preventiva e preditiva, } \\
\text { considerando toda a vida } \\
\text { útil e a confiabilidade do } \\
\text { equipamento. }\end{array}$ & $\begin{array}{l}\text { Evita que as } \\
\text { manutenções sejam } \\
\text { realizadas abaixo ou } \\
\text { acima do necessário, } \\
\text { gerando } \\
\text { respectivamente } \\
\text { quebras e } \\
\text { desperdícios. }\end{array}$ & & $\mathrm{X}$ & $\mathrm{X}$ & $\begin{array}{l}\mathrm{b}, \mathrm{c}, \mathrm{g}, \mathrm{n}, \mathrm{u}, \\
\mathrm{w}, \mathrm{aa}, \mathrm{ae}, \mathrm{af}\end{array}$ \\
\hline 14 & $\begin{array}{c}\text { TPM-EM } \\
\text { (Gerenciamento } \\
\text { de } \\
\text { Equipamentos) }\end{array}$ & $\begin{array}{l}\text { Desenvolvimento de } \\
\text { soluções para a melhoria } \\
\text { do desempenho dos } \\
\text { equipamentos, fazendo } \\
\text { com que os mesmos } \\
\text { exijam menos } \\
\text { manutenções futuras. }\end{array}$ & $\begin{array}{l}\text { Diminui os gastos } \\
\text { com manutenção dos } \\
\text { equipamentos, e } \\
\text { garante a } \\
\text { continuidade das } \\
\text { operações produtivas. }\end{array}$ & & $X$ & $x$ & $\begin{array}{c}\mathrm{b}, \mathrm{c}, \mathrm{g}, \mathrm{n}, \mathrm{u}, \\
\mathrm{w}, \mathrm{aa}, \mathrm{ae}\end{array}$ \\
\hline \multicolumn{8}{|c|}{ SBCE } \\
\hline 15 & SBCE & $\begin{array}{l}\text { Desenvolvimento de } \\
\text { produtos e processos } \\
\text { por meio da análise de } \\
\text { conjuntos de soluções } \\
\text { paralelas, fornecidas } \\
\text { pelas diversas áreas } \\
\text { envolvidas, até que uma } \\
\text { solução mais adequada } \\
\text { seja concordada por } \\
\text { todos. }\end{array}$ & $\begin{array}{l}\text { Amplia as } \\
\text { possibilidades de } \\
\text { soluções e garante } \\
\text { que a implantação } \\
\text { seja rápida. }\end{array}$ & $\mathrm{X}$ & $\mathrm{X}$ & $\mathrm{X}$ & $\mathrm{h}, \mathrm{k}, \mathrm{q}, \mathrm{z}$ \\
\hline
\end{tabular}




\begin{tabular}{|c|c|c|c|c|c|c|}
\hline \multirow[b]{2}{*}{ : } & \multirow[t]{2}{*}{ Nome } & \multirow[t]{2}{*}{ No que consiste } & \multirow[t]{2}{*}{$\begin{array}{l}\text { Como evita } \\
\text { desperdícios }\end{array}$} & \multicolumn{2}{|c|}{$\begin{array}{l}\text { Obje- } \\
\text { tivos }\end{array}$} & \multirow[t]{2}{*}{ Referências } \\
\hline & & & & $\begin{array}{l}0 \\
\frac{0}{0} \\
\frac{\pi}{0} \\
\frac{\pi}{\pi} \\
0 \\
0\end{array}$ & 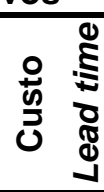 & \\
\hline \multicolumn{7}{|c|}{ Last Planner } \\
\hline 16 & Kit Completo & $\begin{array}{l}\text { Garantia que nenhuma } \\
\text { tarefa tenha início até } \\
\text { que todas as pré- } \\
\text { condições necessárias } \\
\text { estejam satisfeitas. }\end{array}$ & $\begin{array}{l}\text { Evita a ocorrência de } \\
\text { defeitos por falha do } \\
\text { operador. }\end{array}$ & $x$ & & $\begin{array}{l}\text { d, e, i, I, o, r, } \\
t, x, y, a c, a d\end{array}$ \\
\hline 17 & $\begin{array}{l}\text { Medição e } \\
\text { monitoramento } \\
\text { do PPC }\end{array}$ & $\begin{array}{l}\text { Acompanhamento do } \\
\text { indicador de } \\
\text { porcentagem executada } \\
\text { do plano de obra do Last } \\
\text { Planner, com análise das } \\
\text { causas de não- } \\
\text { execução. }\end{array}$ & $\begin{array}{l}\text { Diminui o risco de } \\
\text { propagação de uma } \\
\text { variação. }\end{array}$ & & $\mathrm{X}$ & $\begin{array}{c}\mathrm{d}, \mathrm{i}, \mathrm{l}, \mathrm{r}, \mathrm{t}, \mathrm{x} \\
\mathrm{y}, \mathrm{ac}, \mathrm{ad}\end{array}$ \\
\hline 18 & $\begin{array}{l}\text { Reserva de } \\
\text { Tarefas } \\
\text { Executáveis }\end{array}$ & $\begin{array}{l}\text { Política de manter uma } \\
\text { Reserva de Tarefas } \\
\text { executáveis para um } \\
\text { período específico, } \\
\text { evitando paradas devido } \\
\text { a imprevistos. }\end{array}$ & $\begin{array}{l}\text { Mantém a produção } \\
\text { da obra protegida } \\
\text { contra imprevistos. }\end{array}$ & & $\mathrm{X} \quad \mathrm{X}$ & $\begin{array}{c}\mathrm{d}, \mathrm{i}, \mathrm{l}, \mathrm{r}, \mathrm{t}, \mathrm{x} \\
\mathrm{y}, \mathrm{ac}, \mathrm{ad}\end{array}$ \\
\hline 19 & Lookahead & $\begin{array}{l}\text { Janela de planejamento } \\
\text { para as atividades a } \\
\text { serem executadas em } \\
\text { médio prazo, durante a } \\
\text { qual se procura verificar } \\
\text { se todas as pré- } \\
\text { condições estão } \\
\text { satisfeitas. }\end{array}$ & $\begin{array}{l}\text { Evita a espera por } \\
\text { pré-condições e } \\
\text { impede que estoques } \\
\text { excessivos de } \\
\text { materiais sejam } \\
\text { criados. }\end{array}$ & & $\mathrm{X}$ & $\begin{array}{c}\mathrm{d}, \mathrm{i}, \mathrm{I}, \mathrm{r}, \mathrm{t}, \mathrm{x}, \\
\mathrm{y}, \mathrm{ac}, \text { ad }\end{array}$ \\
\hline
\end{tabular}

Relação das referências consideradas:

(a) FORD (1988)

(b) NAKAJIMA (1989)

(r) BALLARD (2000)

(c) HARTMANN (1992)

(t) CHOO; TOMMELEIN (2001)

(d) KOSKELA (1992)

(u) WAYENBERGH (2001)

(e) RONEN (1992)

(f) SEKINE (1992)

(g) SHIROSE (1992)

(h) WOMACK; JONES; ROOS (1992)

(i) BALLARD (1994)

(j) HIRANO (1995)

(k) WARD et al. (1995)

(l) BALLARD; HOWELL (1997)

(m) OHNO (1997)

(n) YEOMANS (1997)

(o) GROSFELD-NIR; RONEN (1998)

(p) BAMBER (1999)

(q) SOBEK II; WARD; LIKER (1999)

(v) ELIAS; MAGALHÃES (2003)

(w) LEI (2003)

(x) NOBRE; BARROS NETO (2003)

(y) VILLAS-BÔAS (2004)

(z) LIKER (2005)

(aa) ABDULMALEK; RAJGOPAL; NEEDY (2006)

(ab) GALSWORTH (2006)

(ac) BERTELSEN (2007)

(ad) COSTA; JUNGLES; OLIVEIRA (2007)

(ae) HA (2007)

(af) MOORE (2007)

(ag) MÜLLER (2007)

(ah) DENNIS (2008) 


\section{Metodologia de pesquisa}

Este capítulo descreve a metodologia de pesquisa em que a presente dissertação se apóia na busca de seu objetivo que, conforme descrito na Seção 1.2, é analisar as empresas de RDU como sistemas produtivos, sob a perspectiva de racionalização da produção enxuta.

\subsection{Questões de pesquisa}

Para se chegar às questões da pesquisa que norteiam o desenvolvimento do presente trabalho, partiu-se da premissa de que o pensamento enxuto é aplicável a qualquer tipo de organização, ou seja, que qualquer empresa pode obter maior qualidade, menor custo e lead time mais curto se fizer um esforço constante e sistemático de identificação e eliminação do desperdício na produção. Sendo assim, deve haver também uma forma de aplicação deste conceito no setor de utilidades e, mais especificamente, nos processos de construção e de manutenção de RDU.

Em se tratando das práticas enxutas listadas no Capítulo 3, há de se considerar que algumas são classificadas pela literatura como de aplicabilidade universal, como o Sistema 5S e os Grupos Kaizen (LIKER, 2005), enquanto outras são originárias de certos setores da economia que - conforme as Seções $2.4 .1 \mathrm{e}$ 2.4.2 - têm semelhanças com pelo menos um dos processos das RDUs. Sendo assim, pressupõe-se que pelo menos parte delas tenha também aplicabilidade no setor das RDUs, ainda que com alguma adaptação.

Com base nesse pressuposto, procurou-se primeiramente analisar a realidade das empresas de RDU, traçando-se um panorama quanto ao real grau de aplicação das práticas enxutas no setor. Chega-se, então, à primeira questão de pesquisa:

- Q1: Em que medida as empresas responsáveis por Redes de Distribuição de Utilidades (RDUs), aplicam cada uma das práticas de produção enxuta no processo de construção e no processo de manutenção?

Vale lembrar que, conforme exposto na Seção 3.2, a produção enxuta não é um simples conjunto de práticas, mas um sistema cujo objetivo é entregar com maior 
qualidade possível, menor custo possível e lead time mais curto ${ }^{20}$ por meio da constante identificação e eliminação de desperdícios. No caso das RDUs, o valor é definido na Seção 2.3.1 como "fazer com que, por meio de uma rede de distribuição, a utilidade esteja disponível, na quantidade e qualidade necessária, de forma contínua e ininterrupta, na instalação do cliente". Assim, tudo que não estiver contribuindo para este fim pode ser considerado desperdício.

No entanto, há de se considerar que nem sempre a simples aplicação das práticas descritas no Capítulo 3 caracteriza um real interesse em assimilar 0 pensamento enxuto, já que outras motivações podem levar a essa aplicação. São exemplos disso os seguintes:

- O uso de procedimentos padronizados de trabalho pode não ter relação com o pensamento enxuto se o objetivo for simplesmente estabelecer padrões de resultados aceitáveis de forma a obter uma certificação de aderência à norma ISO 9001:2008 (INTERNATIONAL ORGANIZATION FOR STANDARDIZATION, 2008), sem compromisso com a simplificação e a racionalização do processo.

- A metodologia para solução de problemas pode não ter uma "motivação enxuta" se for usada só para investigar acidentes graves que envolvem a segurança, e não para analisar as causas dos imprevistos que geram desperdícios no processo.

Por outro lado, podem existir empresas que não aplicam uma determinada prática enxuta, mas mesmo assim tenham gestores e funcionários cuja racionalidade é coerente com a do pensamento enxuto. Pode acontecer, por exemplo, de uma empresa ainda não ter tido a oportunidade de aplicar o SBCE, mas almejar aplicá-lo brevemente e entender que, ao aplicá-lo, poderá eliminar desperdícios e aprimorar seu processo de entrega de valor ao cliente.

Sendo assim, quatro diferentes situações podem ser encontradas ao considerarmos a forma de aplicação de cada prática enxuta descrita no Capítulo 3 em cada um dos processos:

\footnotetext{
${ }^{20}$ Vale lembrar que a segurança e a moral também fazem parte dos objetivos da Toyota, mas não são abordados nessa dissertação (ver Seção 3.2).
} 
1. A melhor situação é aquela em que a empresa aplica a prática enxuta e esta aplicação tem relação com o pensamento enxuto;

2. Uma situação intermediária é aquela em que a empresa aplica a prática enxuta, mas por outro motivo que não o pensamento enxuto;

3. Outra situação intermediária é aquela em que a empresa não aplica a prática enxuta, mas almeja aplicá-la relacionando-a ao pensamento enxuto;

4. A pior situação é aquela em que a empresa não aplica a prática enxuta, nem entende a necessidade de aplicá-la (ou vê outra motivação para a aplicação futura que não o pensamento enxuto).

Estas quatro situações estão esquematizadas no Quadro 4-1.

Quadro 4-1 - Situações de aplicação das práticas enxutas em empresas de RDU

\begin{tabular}{|c|c|c|}
\hline $\begin{array}{l}\text { Grau de Aplicação (GA) } \\
\text { da prática }\end{array}$ & Baixo & Alto \\
\hline Alto & Situação $2 \bigodot$ & Situação 1 (:) \\
\hline Baixo & Situação 4 : & Situação $3 \bigoplus$ \\
\hline
\end{tabular}

Assim, o grau de aplicação de uma prática enxuta e o grau de relação da aplicação desta prática com o pensamento enxuto constituem duas dimensões diferentes, o que leva à formulação da segunda questão de pesquisa:

- Q2: Em que medida a aplicação atual - ou uma possível aplicação futura - de cada prática enxuta é realmente motivada pelo pensamento enxuto?

Respondidas as questões Q1 e Q2, pode-se partir para uma análise da real aplicabilidade de cada prática no contexto de cada processo da RDU.

Assim, pressupõe-se que a aplicação de uma prática enxuta em dado processo, apresentando ainda relação com o pensamento enxuto, mostra que esta prática é passível de aplicação no contexto em questão. Esta aplicabilidade ou pode ser direta, ou pode requerer alguma adaptação às características peculiares dos processos de construção e manutenção das RDUs descritas nas Seções 2.4.1 e 2.4.2. 
Em contrapartida, se não houver aplicação de certa prática enxuta no processo considerado, ou se houver tal aplicação, mas a mesma não estiver em consonância com o pensamento enxuto, a aplicabilidade ou utilidade de tal prática pode ser muito limitada às circunstâncias e necessidades do processo em que isso ocorrer. Há de se considerar, porém, que a falta de aplicação de uma prática, ou de relação com as motivações do pensamento enxuto, também pode ser reflexo do simples desconhecimento da mesma pela equipe, à falta de recursos para sua aplicação ou até ao desinteresse da empresa considerada. Assim, as relações entre o grau de aplicação e a aplicabilidade e entre o grau de relação e a aplicabilidade podem não ser diretas, e devem ser analisadas de forma crítica.

Com isso, chega-se à terceira questão da pesquisa:

- Q3: Quais das práticas da produção enxuta são aplicáveis nos processos de construção e manutenção de empresas de RDU, levandose em conta o objetivo de eliminação do desperdício?

Por meio da elucidação e discussão da Questão Q3, o presente trabalho procura definir o que se pode fazer para melhorar a produtividade das empresas de RDU por meio da abordagem da produção enxuta, visando assim ao objetivo estabelecido na Seção 1.2.

\subsection{Escolha do método de pesquisa}

Wacker (1998) considera que existem dois tipos diferentes de pesquisa: analítica e empírica. A primeira é mais aplicável a ciências baseadas primariamente em regras dedutíveis (como a matemática e a lógica); a segunda depende de empirismo e indução (como a química, a psicologia e a educação).

No campo de gestão de operações, este autor defende que ambas as abordagens têm seu lugar. A pesquisa analítica, no entanto, parte do princípio que os dados já existam, e busca chegar a novas conclusões por meio da construção de novas relações lógicas, modelos matemáticos ou teorias estatísticas. Quando há necessidade de se buscar dados no mundo real para testar a teoria, como é o caso desta dissertação, é recomendada a pesquisa empírica. 
Segundo Wacker (1998), a pesquisa empírica ainda é subdividida nas seguintes três subcategorias, explicadas mais detalhadamente, respectivamente, por Coughlan e Coghlan (2002); Forza (2002) e Voss, Tsikritsis e Frohlic (2002):

- Pesquisa empírica experimental (ou pesquisa-ação) - investiga as relações por meio da manipulação de variáveis e análise dos resultados.

- Pesquisa empírica estatística (ou pesquisa survey) - verifica as relações teóricas de forma empírica, por meio da análise estatística de grandes amostras de organizações reais.

- Estudo de caso empírico (ou estudo de caso) - desenvolve relações com base em um conjunto limitado de organizações, mas com um grande número de variáveis em cada uma.

A subcategoria escolhida para balizar o desenvolvimento desta dissertação é a do estudo de caso. Tal escolha se deve às seguintes razões:

- Embora a aplicação da produção enxuta em diversos setores seja um assunto bastante discutido na literatura, sua aplicação específica no setor de RDU ainda é incipiente (ver Seção 1.1). Segundo Bernbasat, Goldstein e Mead (1987); Meredith (1998) e Voss, Tsikritsis e Frohlic (2002), pesquisas baseadas em estudos de caso são consideradas particularmente apropriadas para teorias que estão nos estágios precoces de formação, ou seja, em que poucos estudos tiverem sido executados.

- A literatura sobre produção enxuta deixa claro que o melhor modo de se verificar como o pensamento enxuto é aplicado em campo é a observação prática, considerando-se as particularidades de cada situação (WOMACK; JONES; ROSS, 1992; OHNO, 1997; LIKER, 2005; BALLÉ; BALLÉ, 2006; LIKER, MEIER, 2007). Segundo Bernbasat, Goldstein e Mead (1987); Meredith (1998) e Voss, Tsikritsis e Frohlic (2002), o método de estudo de caso é mais aplicável quando o fenômeno deve ser observado na prática.

Soma-se a isso a incoerência de se executar os outros dois tipos de pesquisa empírica - pesquisa-ação e pesquisa-survey - no contexto em questão. A pesquisaação se aplica quando o objeto de estudo está em processo de mudança, e exige que os pesquisadores sejam participantes neste processo, ou seja, "tomem ações, e 
não simplesmente observem algo acontecendo" (COUGHLAN; COGHLAN, 2002, p. 224). No presente estudo, não há processo de mudança em andamento, tampouco envolvimento direto do pesquisador. No caso da pesquisa survey, são necessárias grandes amostras para viabilizar uma análise estatística (WACKER, 1998; FORZA, 2002); contudo, na região em que se desenvolveu o presente estudo há somente três empresas que podem ser classificadas como RDUs, sendo que uma atua no setor de distribuição de água, outra na de energia elétrica e a terceira na de gás natural.

\subsection{Considerações sobre o método de pesquisa escolhido - o Estudo de Caso}

Autores como Bonoma (1993); Meredith (1998); Voss, Tsikritsis e Frohlic (2002) e Yin (2005) expõem algumas considerações a serem levadas em conta na execução de estudos de caso.

A primeira é a decisão quanto ao número de entidades a serem avaliadas. Voss, Tsikritsis e Frohlic (2002) explicam que a definição da quantidade de casos depende de uma escolha entre profundidade e generalização. Quanto menor o número de casos, maior a oportunidade de se fazer uma observação mais profunda; em contrapartida, a análise de um maior número de casos aumenta a oportunidade de generalização de fatos à população representada. Nesta dissertação, optou-se por executar três estudos de caso, sendo um em cada tipo de RDU: distribuição de água, energia elétrica e gás natural. Com isso, pretende-se traçar uma análise de caráter mais geral, cujos resultados possam ser estendidos ao universo das RDUs, em detrimento a uma análise mais aprofundada, mas restrita a um único caso.

A segunda é a escolha entre a realização de estudos de caso incorporados ou holísticos. Segundo Yin (2005), estudos de caso incorporados ocorrem quando, dentro de cada caso, dá-se atenção a uma subunidade ou a várias subunidades; em contraste, se o estudo de caso examinar apenas a natureza global de um programa ou de uma organização, utiliza-se a denominação estudo de caso holístico. $\mathrm{Na}$ presente pesquisa, optou-se por estudos de caso incorporados, avaliando-se duas subunidades distintas de cada caso - quais sejam, os processos de construção e 
manutenção definidos na Seção 2.4 - permitindo assim uma comparação entre os mesmos.

A terceira, levantada por Meredith (1998), refere-se à escolha dos métodos e ferramentas para coleta de dados. O método escolhido como fonte primária foi a entrevista, a ser conduzida junto a gestores responsáveis por cada um dos dois processos em cada uma das três empresas. No entanto, Bonoma (1985), Yin (2005) e Meredith (1998) enfatizam que é necessário acumular múltiplas entidades como fontes de suporte de evidência, para garantir a denominada "triangulação perceptual". No presente estudo, a triangulação foi buscada por meio da solicitação ao entrevistado - quando praticável - de evidências a respeito dos dados apresentados.

As três características da forma de aplicação do método de estudo de caso neste trabalho estão resumidas no Quadro 4-2.

Quadro 4-2 - Características da pesquisa de caso e aplicação na presente dissertação

\begin{tabular}{|c|c|c|}
\hline Característica & No que consiste & Aplicação na presente dissertação \\
\hline $\begin{array}{l}\text { Número de } \\
\text { casos }\end{array}$ & $\begin{array}{l}\text { Definição da quantidade de casos com } \\
\text { base na escolha entre profundidade e } \\
\text { generalização. }\end{array}$ & $\begin{array}{l}\text { Execução de três estudos de caso, um } \\
\text { em cada tipo de RDU. }\end{array}$ \\
\hline $\begin{array}{l}\text { Estudos de } \\
\text { caso } \\
\text { incorporados } \\
\text { versus } \\
\text { holísticos }\end{array}$ & $\begin{array}{l}\text { Opção por se analisar uma ou várias } \\
\text { subunidades de cada caso (estudos de } \\
\text { caso incorporados) ou se examinar cada } \\
\text { organização apenas de maneira global } \\
\text { (estudos de caso holísticos). }\end{array}$ & $\begin{array}{l}\text { Optou-se por estudos de caso } \\
\text { incorporados, com a análise dos } \\
\text { processos de construção e manutenção } \\
\text { em cada empresa estudada. }\end{array}$ \\
\hline $\begin{array}{l}\text { Métodos e } \\
\text { ferramentas } \\
\text { para coleta }\end{array}$ & $\begin{array}{l}\text { Acumulação de múltiplas entidades como } \\
\text { fontes de suporte de evidência, para } \\
\text { garantir que os fatos sendo coletados } \\
\text { sejam realmente corretos. }\end{array}$ & $\begin{array}{l}\text { Obtenção dos dados através de } \\
\text { entrevistas, e solicitação ao } \\
\text { entrevistado de evidências a respeito } \\
\text { dos dados apresentados. }\end{array}$ \\
\hline
\end{tabular}

\subsection{Descrição da metodologia}

A pesquisa é desenvolvida de forma a responder às questões expostas na Seção 4.1, e, conseqüentemente, contribuir para o atendimento aos objetivos da dissertação expostos na Seção 1.2.

Conforme definido na seção anterior, são três os estudos de caso desenvolvidos neste trabalho, abrangendo empresas que operam em setores diferentes, porém todas classificadas como de RDU, conforme seguem:

- Uma empresa distribuidora de gás natural (EMPRESA A); 
- Uma empresa distribuidora de água e coletora de esgoto (EMPRESA B);

- Uma empresa distribuidora de energia elétrica (EMPRESA C).

O primeiro estudo de caso serviu como um piloto para análise da metodologia em si, e naturalmente exigiu mais tempo para sua execução e repetição após os ajustes necessários.

Em cada empresa, foram entrevistados gestores de áreas responsáveis pelos dois processos tomados como objeto de estudo, totalizando seis entrevistas. Os processos estudados foram:

- Construção de RDU;

- Manutenção de RDU.

Na coleta de dados sobre ambos os processos, foi esclarecido ao entrevistado que o escopo da pesquisa se restringia às atividades executadas em vias públicas e que, no caso da manutenção, somente a manutenção preventiva seria considerada, seguindo as definições de escopo expostas na Seção 2.4 .

\subsubsection{Condução das entrevistas}

Para a coleta de dados, optou-se pela abordagem de entrevistas semiestruturadas, que são conduzidas de acordo com um guia e restringindo-se a certos temas a serem contemplados por questões direcionadoras, mas permitindo certa abertura conforme o andamento das respostas (KVALE, 1996). Assim, esta abordagem constitui um meio termo entre uma conversa aberta não-estruturada e um questionário rigidamente definido.

Os entrevistados foram informados que se tratava de uma pesquisa acadêmica sobre a aplicação de práticas para melhoria do desempenho em empresas de utilidades. Para evitar respostas enviesadas, o relacionamento da pesquisa com temas como produção enxuta ou eliminação de desperdícios não foi mencionado de início.

Em cada sessão, primeiramente, foi solicitado ao entrevistado que explicasse 0 cotidiano de trabalho de sua equipe, suas responsabilidades em relação à empresa e seus principais clientes e fornecedores. O objetivo desta etapa era de entender 0 contexto em questão para ajustar as perguntas ao mesmo. 
Em seguida, as práticas enxutas listadas no Quadro 3-5 da Seção 3.5 foram introduzidas e discutidas uma a uma. Para evitar problemas de interpretação durante as entrevistas, evitou-se mencionar os nomes das práticas durante a entrevista, mantendo-se somente em sua descrição (coluna "No que consiste" do Quadro 3-5).

Em cada entrevista, o entrevistador primeiramente descreveu a Prática 1 (referente a Procedimentos Habilitadores) e esclareceu as dúvidas manifestadas pelo entrevistado a respeito da abrangência da mesma. Em seguida, perguntou se o entrevistado aplicava aquela prática em seu dia-a-dia. Em caso positivo, o entrevistado foi incitado a descrever e, se possível, mostrar evidências de aplicação para garantir a triangulação perceptual.

A segunda pergunta sobre a mesma prática diz respeito à motivação para aplicação da mesma. Caso o entrevistado respondesse afirmativamente à primeira pergunta, ou seja, que aquela prática era aplicada, ele era questionado sobre o motivo de sua aplicação. Caso a resposta à primeira pergunta fosse negativa, 0 entrevistado era questionado se ele via alguma motivação para aplicar aquela prática no futuro e, se positivo, qual seria essa motivação.

Então, cada entrevista teve continuidade, avançando para a prática seguinte constante no Quadro 3-5 e fazendo as mesmas duas perguntas, até a 19ạ e última prática (Lookahead). O programa de entrevista está diagramado na Figura 4-1. 


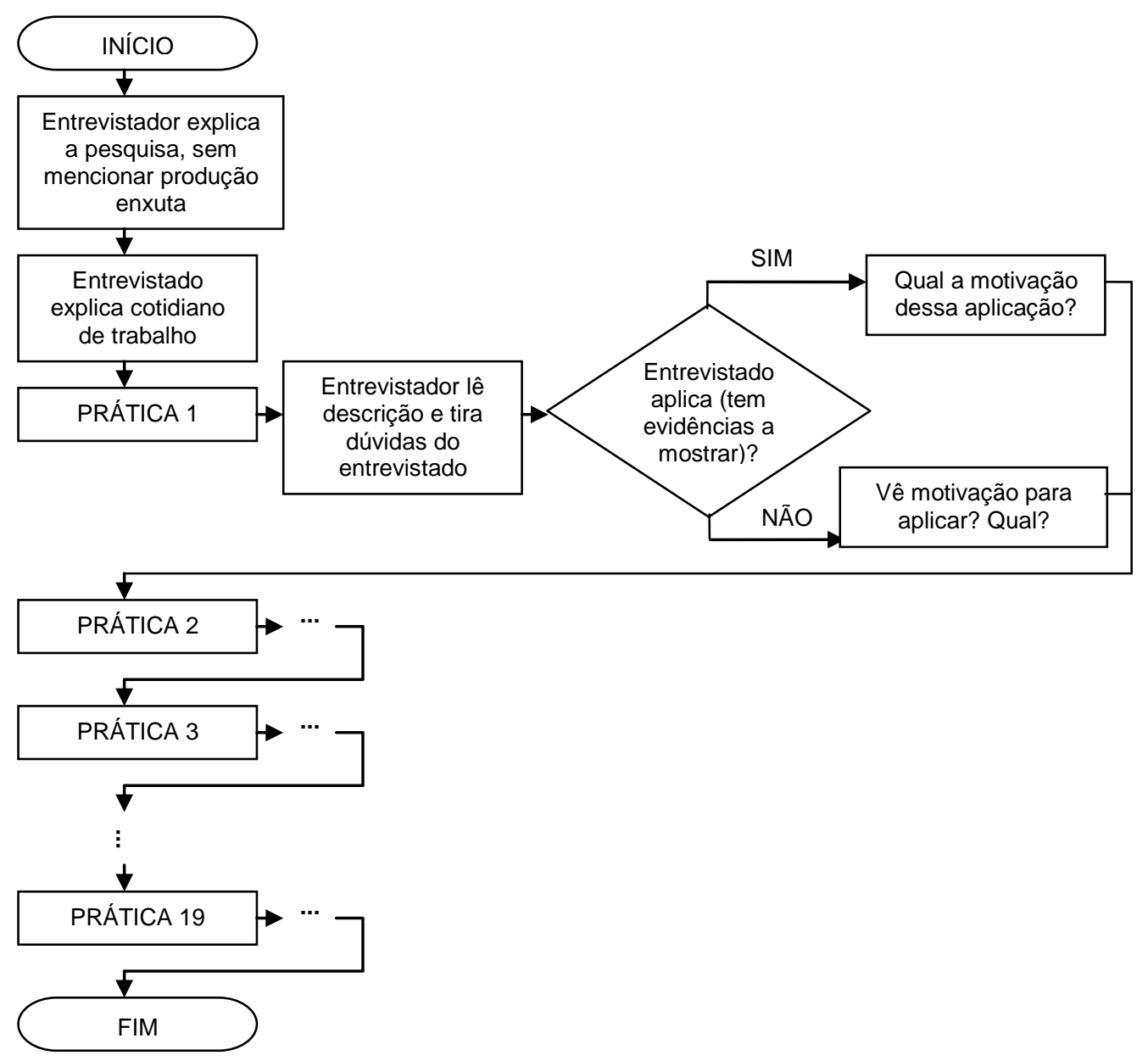

Figura 4-1 - Programa das entrevistas

\subsubsection{Tabulação dos dados}

A tabulação dos dados foi feita após cada entrevista, sem a presença do entrevistado. As respostas obtidas para cada prática em cada entrevista servem de base para a definição de duas medidas: Grau de Aplicação (GA) e Grau de Relação (GR).

O Grau de Aplicação (GA) é obtido da resposta à primeira pergunta, ou seja, se a empresa aplica a prática descrita em seu dia-a-dia. Conforme as informações fornecidas e as evidências apresentadas, no presente trabalho o grau de aplicação GA é medido conforme segue:

- 0: Nenhuma evidência de aplicação;

- 1: Aplicação parcial;

- 2: Aplicação efetiva. 
Vale ressaltar que esta escala difere de outras apresentadas pela literatura para se medir o grau de implementação da produção enxuta em organizações manufatureiras. A norma SAE J4001 (SAE International, 1999), por exemplo, apresenta cinquenta e dois componentes da produção enxuta e estabelece que o avaliador deve atribuir notas de zero a três para cada componente, dependendo do que for observado em campo. Nesta dissertação, optou-se por desenvolver uma escala específica devido ao foco nas práticas enxutas listadas no Quadro 3-5 da Seção 3.5 .

Já o Grau de Relação (GR) é obtido da resposta à segunda pergunta, ou seja, mostra se o entrevistado demonstra que a motivação para a aplicação atual (ou possível aplicação futura) de cada prática está relacionada com a do pensamento enxuto. Se ele acredita naquela prática como um meio de obter maior qualidade, menor custo e/ou menor lead time pela identificação e eliminação de desperdícios, o Grau de Relação é maior.

Em empresas que aplicam uma prática dita enxuta, um GR positivo significa que o pensamento enxuto é, pelo menos em parte, a motivação para tal aplicação, ou seja, que a aplicação daquela prática visa à obtenção da melhor qualidade, menor custo ou menor lead time por meio da eliminação do desperdício. Um GR nulo, por sua vez, indica que a empresa teve outros motivos para implantá-la, ou seja: pode ter sido motivada a aplicá-la exclusivamente por aspectos ligados à segurança, pode tê-la adotado para obter certificados como ISO-9001 ou simplesmente para obedecer a uma lei específica.

Já em empresas que não aplicam uma determinada prática, um GR positivo significa que o entrevistado vê possibilidade de aplicação futura desta prática, e ainda crê que a mesma contribuirá para obter maior qualidade, menor custo e/ou menor lead time. Um GR nulo, neste caso, pode significar duas situações: o entrevistado não acredita na possibilidade de aplicação futura daquela prática ou, se acredita, a motivação não se deve ao pensamento enxuto, ou seja: ele não vê ganhos à empresa em termos de qualidade, custo ou lead time.

O Grau de Relação é medido conforme segue:

- 0: Nenhuma relação com o pensamento enxuto;

- 1: Alguma relação com o pensamento enxuto; 
- 2: Forte relação com o pensamento enxuto.

Nos casos em que for atribuído um Grau de Relação diferente de zero, o mesmo é justificado pela menção ao objetivo (ou ao grupo de objetivos) que for percebido na entrevista para a aplicação (atual ou futura) daquela prática. Assim, ao lado do valor que indica o GR da prática para determinado processo em uma empresa, atribui-se o parâmetro:

- Q: se for percebido o objetivo de melhorar Qualidade;

- C: se for percebido o objetivo de diminuir Custo;

- LT: se for percebido o objetivo de diminuir Lead Time.

É importante notar que é possível que na investigação de um caso, se contate que a aplicação de uma dada prática em um dado processo seja motivada por mais de um objetivo entre Qualidade, Custo e Lead Time. Porém, vale lembrar que não há uma relação direta entre o número de objetivos (um, dois ou três) e o Grau de Relação - uma prática pode, por exemplo, ter uma forte relação com um dos três objetivos, e por isso ser avaliada com $\mathrm{GR}=2$, enquanto outra pode ter uma relação com dois ou até três objetivos, mas com menor intensidade, e por isso receber $\mathrm{GR}=1$.

O formulário para tabulação dos resultados de cada entrevista encontra-se no Quadro 4-3. 
Quadro 4-3 - Formulário de tabulação dos dados das entrevistas

\begin{tabular}{|c|c|c|c|c|}
\hline \multirow{2}{*}{$\begin{array}{l}\text { Prática } \\
\text { Padron }\end{array}$} & \multicolumn{2}{|r|}{ Nome } & \multirow[t]{2}{*}{ GA } & \multirow[t]{2}{*}{ GR } \\
\hline & zação e Estabilidade & & & \\
\hline 1 & \multicolumn{2}{|l|}{ Procedimentos habilitadores } & $x x$ & $x x$ \\
\hline 2 & \multicolumn{2}{|l|}{ Sistema 5S } & $x x$ & $x x$ \\
\hline 3 & \multicolumn{2}{|l|}{ Heijunka } & $\mathrm{xx}$ & $x \mathrm{x}$ \\
\hline \multicolumn{5}{|c|}{ Just-In-Time } \\
\hline 4 & \multicolumn{2}{|l|}{ Fluxo Contínuo / Takt time } & $x x$ & $x x$ \\
\hline 5 & \multicolumn{2}{|l|}{ Sistema puxado } & $x x$ & $x x$ \\
\hline 6 & \multicolumn{2}{|l|}{ Setup Rápido } & $x x$ & $x x$ \\
\hline \multicolumn{5}{|l|}{ Jidoka } \\
\hline 7 & \multicolumn{2}{|l|}{ Autonomação } & $x x$ & $x x$ \\
\hline 8 & \multicolumn{2}{|l|}{ Poka-yoke } & $x x$ & $x x$ \\
\hline \multicolumn{5}{|c|}{ Envolvimento } \\
\hline 9 & \multicolumn{2}{|l|}{ Solução de Problemas } & $x x$ & $x x$ \\
\hline 10 & \multicolumn{2}{|l|}{ Grupos kaizen } & $x x$ & $x x$ \\
\hline 11 & \multicolumn{2}{|l|}{ Programa de Sugestão } & $x x$ & $x \mathrm{x}$ \\
\hline \multicolumn{5}{|l|}{ TPEM } \\
\hline 12 & \multicolumn{2}{|c|}{ TPM-AM (Manutenção Autônoma) } & $x x$ & $x x$ \\
\hline 13 & \multicolumn{2}{|c|}{ TPM-PM (Manutenção Preventiva e Preditiva) } & $x x$ & $x x$ \\
\hline 14 & \multicolumn{2}{|c|}{ TPM-EM (Gerenciamento de Equipamentos) } & $x x$ & $x \mathrm{x}$ \\
\hline \multicolumn{5}{|c|}{ 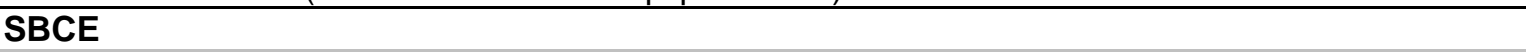 } \\
\hline 15 & \multicolumn{2}{|l|}{ SBCE } & $x x$ & $x x$ \\
\hline \multicolumn{5}{|c|}{ Last Planner } \\
\hline 16 & \multicolumn{2}{|l|}{ Kit Completo } & $x x$ & $x x$ \\
\hline 17 & \multicolumn{2}{|c|}{ Medição e monitoramento do PPC } & $x x$ & $x x$ \\
\hline 18 & \multicolumn{2}{|c|}{ Reserva de Tarefas Executáveis } & $x x$ & $x x$ \\
\hline 19 & Lookahead & & $x x$ & $x x$ \\
\hline \multicolumn{2}{|c|}{$\begin{array}{l}\text { Grau de Aplicação (GA): } \\
\text { 0: Nenhuma evidência de aplicação } \\
\text { 1: Aplicação parcial } \\
\text { 2: Aplicação efetiva }\end{array}$} & \multicolumn{3}{|c|}{$\begin{array}{l}\text { Grau de Relação (GR): } \\
\text { 0: Nenhuma relação com a eliminação do desperdício; } \\
\text { 1: Alguma relação com a eliminação do desperdício; } \\
\text { 2: Forte relação com a eliminação do desperdício; } \\
\text { Q; Percebido o objetivo de melhorar Qualidade; } \\
\text { C: Percebido o objetivo de diminuir Custo; } \\
\text { LT: Percebido o objetivo de diminuir Lead Time. }\end{array}$} \\
\hline
\end{tabular}

\subsubsection{Compilação dos dados para análise}

O formulário do Quadro 4-3 será utilizado para apresentar os dados coletados e avaliados em uma única entrevista, ou seja, mostra os Graus de Aplicação (GA) e Graus de Relação (GR) de todas as práticas analisadas em cada processo (construção ou manutenção) de cada empresa (Empresa A, Empresa B ou Empresa C).

Deve-se considerar, no entanto, que para se discutir as questões de pesquisa expostas na Seção 4.1, os dados mais importantes não são aqueles obtidos separadamente em cada empresa, mas sim os resultados aplicados referentes à amostra de casos pesquisados, que representa o universo das RDUs. Nesse sentido, faz-se necessário definir as variáveis cumulativas Grau de Aplicação Geral 
(GAG) e o Grau de Relação Geral (GRG), a serem calculadas com base nos resultados obtidos em todos os estudos de caso na etapa de análise de dados, ou seja, os Graus de Aplicação e de Relação para cada prática em cada processo independentemente da empresa estudada.

O valor do GAG será calculado como a somatória dos Graus de Aplicação (GA) obtidos em todas as empresas para uma dada prática em um dado processo (construção ou manutenção), através da fórmula:

$$
G A G_{(i, j)}=\sum_{k=1}^{n} G A_{(i, j, k)}, \text { onde: }
$$

i é a prática em questão (Procedimentos Habilitadores, Sistema 5S, etc.);

j é o processo em questão (construção ou manutenção);

$k$ refere-se a cada uma das empresas estudadas (Empresa A, B e C);

$n$ é o número total de empresas. Nesta dissertação, $n$ é igual a três.

O cálculo do GAG permitirá que se analise em que medida as empresas responsáveis pelas RDUs aplicam cada uma das práticas de produção enxuta em cada processo e será utilizada na elucidação e discussão da Questão Q1. Se todas as empresas analisadas demonstrarem evidências de aplicação efetiva para uma dada prática $i$ em um processo j, ter-se-á:

$$
\begin{aligned}
& G A_{(i, j, k)}=2, \text { parak }=1 \text { até n } \\
& G A G_{(i, j)}=\sum_{k=1}^{n} G A_{(i, j, k)}=n \times 2=2 n \\
& \text { paran }=3 \Rightarrow G A G_{(i, j)}=3 \times 2=6
\end{aligned}
$$

No entanto, se nenhuma das empresas demonstrarem evidência alguma de aplicação para outra prática i' no mesmo processo j, ter-se-á:

$$
\begin{aligned}
& G A_{\left(i^{\prime}, j, k\right)}=0, \text { parak }=1 \text { até n } \\
& G A G_{\left(i^{\prime}, j\right)}=\sum_{k=1}^{n} G A_{\left(i^{\prime}, j, k\right)}=n \times 0=0 n \\
& \text { paran }=3 \Rightarrow G A G_{(i, j)}=3 \times 0=0
\end{aligned}
$$

Assim, nesta dissertação, o valor de GAG para cada prática em um dado processo será sempre medido em uma escala de zero a seis (Figura 4-2). 


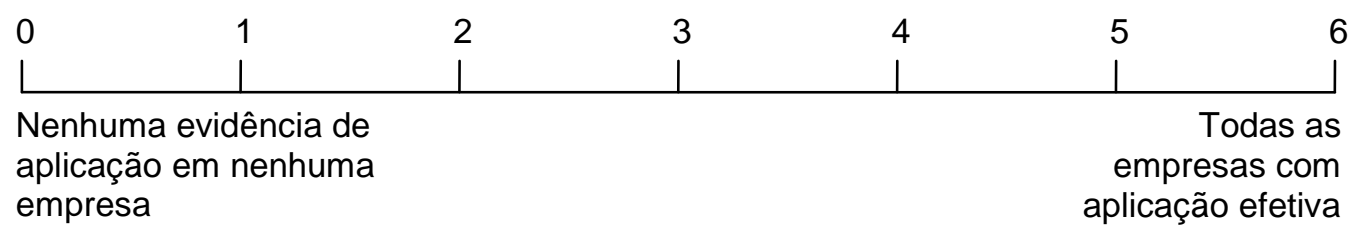

Figura 4-2 - Escala do Grau de Aplicação Geral (GAG)

Analogamente, o valor do GRG será calculado como a somatória dos Graus de Relação (GR) obtidos em todas as empresas para uma dada prática, considerando apenas um dos processos (construção ou manutenção).

$$
G R G_{(i, j)}=\sum_{k=1}^{n} G R_{(i, j, k)} \text {, onde } i, j, k \text { e } n \text { têm os mesmos significados que na }
$$
fórmula utilizada no cálculo do GAG.

O cálculo do GRG permitirá que se analise em que medida a aplicação atual ou uma possível aplicação futura - de cada prática enxuta é realmente motivada pelo pensamento enxuto e será utilizado na elucidação e discussão da Questão Q2. Seguindo uma lógica análoga à desenvolvida para o GAG, pode-se verificar que se todas as empresas da amostra demonstrarem forte relação com o pensamento enxuto para dada prática em dado processo, o valor de GRG será seis; em contrapartida, se nenhuma empresa demonstrar relação com o pensamento enxuto para uma certa prática um dado processo, o valor de GRG será zero. Assim, os valores de GRG poderão variar em uma escala de zero e seis (Figura 4-3).

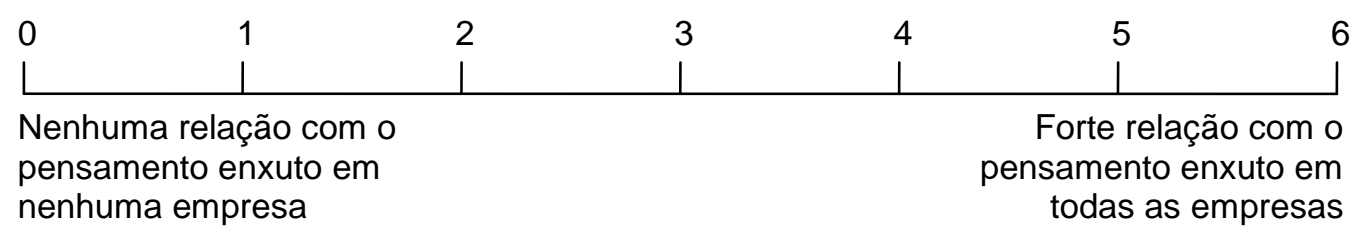

Figura 4-3 - Escala do Grau de Relação Geral (GRG)

Vale lembrar que tanto o GAG quanto o GRG também contribuirão para a elucidação e discussão da Questão Q3, pois, conforme informado na Seção 4.1, a aplicabilidade de cada prática enxuta em cada processo tomado como objeto de estudo será avaliada por meio de uma análise crítica das discussões que serão geradas a partir das duas primeiras questões. 


\section{Descrição dos casos}

Este capítulo é dedicado à apresentação e descrição dos casos estudados nas três empresas de RDU investigadas na pesquisa de campo:

- A Empresa A que atua no setor de distribuição de gás natural;

- A Empresa B que atua no setor de distribuição de água; e

- A Empresa C que atua no setor de distribuição de energia elétrica.

\subsection{Empresa A - Distribuição de gás natural}

A Empresa A é uma distribuidora de gás natural, que está estabelecida no mercado desde o final do século XIX, mas foi privatizada somente na década de 1990, e atualmente está sob controle acionário de um grupo estrangeiro. Conta com cerca de 800 empregados diretos e abastece 700.000 consumidores.

\subsubsection{Processo de construção de redes de distribuição de gás natural}

A coleta de dados sobre o processo de construção de redes de gás natural foi realizada por meio de uma entrevista com um gerente de projetos de expansão da empresa.

O gerente iniciou a entrevista explicando que suas atribuições incluem todos os processos de campo necessários para a expansão da rede de gás natural em uma determinada região, o que inclui, resumidamente: o projeto da rede a ser construída, a obtenção dos materiais necessários, a contratação de mão-de-obra, a construção da rede em si e a ligação de novos consumidores à rede construída. Seus principais fornecedores diretos são: a área de marketing da empresa, que fornece o grupo de consumidores a ser ligado, já previamente contratado; a projetista, que elabora os projetos executivos; a Área de Suprimentos, que disponibiliza os materiais necessários; a empreiteira, que fornece mão-de-obra e equipamentos para a construção; e a área de relações institucionais, que negocia a disponibilidade do espaço junto à prefeitura e demais órgãos. Entre os clientes, estão o próprio consumidor, que passa a receber o gás natural para consumo, e a área de 
manutenção, que se torna responsável pela rede recém-construída. O Quadro 5-1 sintetiza o processo de construção da Empresa A.

Quadro 5-1 - Processo de construção de redes de gás natural pela Empresa A

\begin{tabular}{|c|c|c|}
\hline Fornecedores (e o que fornecem) & Processos atribuídos & Clientes (e o que recebem) \\
\hline $\begin{array}{l}\text { Internos: } \\
\text { - Marketing (consumidores a serem } \\
\text { ligados) } \\
\text { - Área de Suprimentos (materiais) } \\
\text { - Relações Institucionais (negociação } \\
\text { do espaço) } \\
\text { Externos: } \\
\text { - Projetista (projetos executivos) } \\
\text { Empreiteira (mão-de-obra e } \\
\text { equipamentos) }\end{array}$ & $\begin{array}{l}\text { - } \text { Projeto de rede } \\
\text { - Obtenção de materiais } \\
\text { - Contratação de mão- } \\
\text { de-obra } \\
\text { - Construção de rede } \\
\text { Ligação de consumidores }\end{array}$ & $\begin{array}{l}\text { Internos: } \\
\text { - Manutenção (rede a ser } \\
\text { mantida) } \\
\text { Externos: } \\
\text { - Consumidor (gás natural) }\end{array}$ \\
\hline
\end{tabular}

Uma descrição do caso baseada nos dados obtidos por meio da entrevista é apresentada a seguir. $\mathrm{Na}$ descrição deste caso, assim como nos casos B e C, os graus de aplicação (GA) e de relação (GR) de cada prática enxuta são indicados entre parênteses, da seguinte forma:

- GA=m (sendo $m=0,1$ ou 2) significa que $\circ$ Grau de Aplicação desta prática foi considerado igual a $m$ pelo pesquisador, face à resposta do entrevistado e evidências citadas e/ou apresentadas, seguindo a escala apresentada na Seção 4.4.2.

- GR=n (para $n=0,1$ ou 2) significa que $\circ$ Grau de Relação desta prática foi considerado igual a $n$ pelo pesquisador, face à resposta do entrevistado, seguindo a escala apresentada na Seção 4.4.2. Nos casos em que o GR é igual a 1 ou 2, o objetivo da produção enxuta que foi percebido (ou objetivos, se for mais de um) é também identificado: Qualidade (Q), Custo (C) e/ou Lead Time (LT).

\section{Padronização e estabilidade}

- Procedimentos habilitadores: Foram mostrados exemplos de procedimentos de trabalho simples, padronizados e adequados às atividades. No entanto, sua elaboração, conforme consta, não é feita pelos próprios funcionários responsáveis pelas atividades, e sim por engenheiros de escritório $(G A=1)$. O foco desses procedimentos está voltado aos padrões exigidos para garantir a segurança das pessoas e das instalações, havendo pouca 
preocupação com aspectos que melhorem os padrões em qualidade, custo ou lead time $(\mathbf{G R}=\mathbf{0})$.

- Sistema 5S: Foi comentado que, já há alguns anos, houve a implantação de um programa de manutenção da ordem visual no trabalho, com base no Sistema 5S, o qual vem sendo continuamente monitorado desde então. As empreiteiras também são monitoradas quanto a este quesito por meio de inspeções executadas nos locais de obra. As evidências apresentadas foram o próprio ambiente de trabalho onde ocorreu a entrevista, que se mostrou bastante limpo e organizado, e o formulário de inspeção de obra, contendo itens relacionados à organização, mostrado na Figura 5-1 (GA=2). A entrevista mostrou que a aplicação do $5 \mathrm{~S}$ na empresa está relacionada com uma motivação do pensamento enxuto, já que, segundo o entrevistado, "as coisas ficaram mais fáceis de achar e, assim, não se perde mais tempo com a procura". (GR=2 - LT).

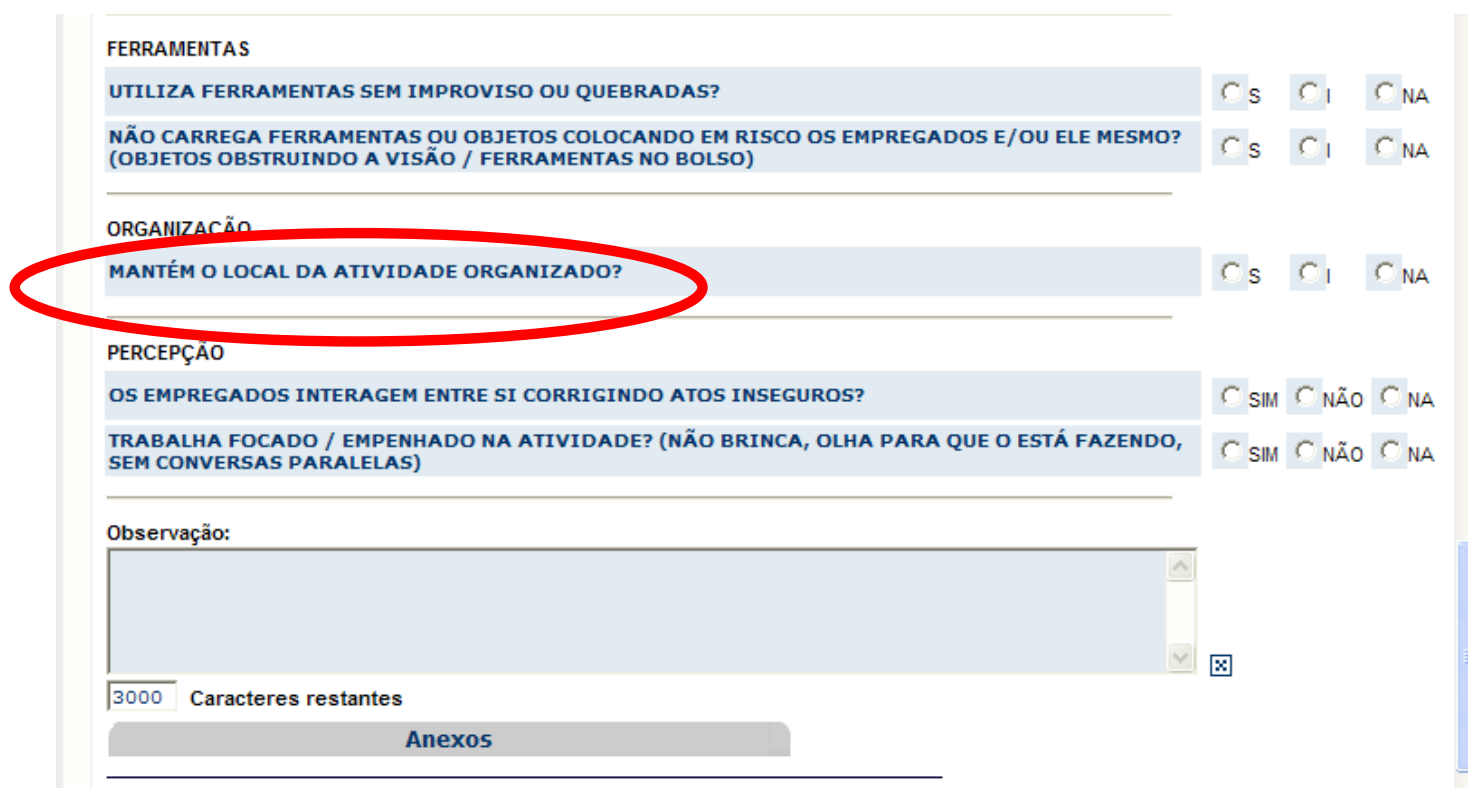

Figura 5-1 - Detalhe do formulário de inspeção de obra da Empresa A, mostrando a preocupação com a organização

- Heijunka: O entrevistado lamentou que o nivelamento não fosse uma prática corriqueira na empresa. Por meio de gráficos, ele mostrou que o ritmo de expansão da rede oscila substancialmente ao longo de cada ano, mantendose principalmente concentrada nos últimos meses, quando as equipes correm para atingir suas metas anuais $(\mathbf{G A}=\mathbf{0})$. No entanto, ele demonstra preocupação com este tema e acredita que o nivelamento em volume traria 
benefícios à equipe, diminuindo a sobrecarga nos picos e a ociosidade nos vales, diminuindo o custo total. Porém, ele considera difícil levar em conta a idéia do nivelamento em mix, ou seja, fazer a mesma combinação de atividades a cada período, uma vez que o processo é muito variável ( $\mathbf{R} \mathbf{R = 1}$.

\section{Just-In-Time}

- Fluxo Contínuo / Takt time: não foi apresentada nenhuma situação em que a seqüência de passos de um processo tenha sido detalhada ao ponto de estabelecer um ritmo adequado $(\mathbf{G A}=\mathbf{0})$. O entrevistado também não acredita que essa prática seria passível de implantação no processo de construção, devido à própria complexidade inerente a este processo (ver Seção 2.4.1), em que o local da construção pode variar a cada dia e envolver trabalhos diferentes executados por diferentes equipes $(\mathbf{G R}=\mathbf{0})$.

- Sistema puxado: não há evidências da existência de um sistema formal em que o processo à jusante especifica o trabalho a ser executado pelo processo à montante. Segundo o entrevistado, o que ocorre, no caso de excesso de carga, é uma negociação nas reuniões semanais da equipe para re-estabelecer o ritmo de trabalho, mas isso não pode ser considerado um sistema puxado ( $\mathbf{G A = 0 )}$. O entrevistado também não sabe como poderia tentar adaptar o sistema puxado à sua realidade (GR=0).

- Setup Rápido: Não há conhecimento da aplicação do conceito de Setup Rápido no processo de construção da Empresa $A(G A=0)$. No entanto, o entrevistado lembrou de uma situação interessante em que o conceito de Setup Rápido poderia ser aplicado: quando uma equipe termina o trabalho em certo local, sempre existe um processo de desmobilização, transporte para um novo local e posterior mobilização nesse novo local. Este processo poderia ser racionalizado, porém não é controlado pela Empresa $A$ por ser executado pelas empreiteiras ( $\mathbf{R} \mathbf{R}=\mathbf{0})$.

\section{Jidoka}

- Autonomação. Foram apresentados alguns casos - embora raros - de dispositivos capazes de informar a ocorrência de problemas e evitar que os mesmos se propaguem. Um exemplo é o chamado fusível mecânico para tração de tubulação (Figura 5-2), utilizado no puxamento de tubos para 
instalação subterrânea por meio de furo direcional horizontal ${ }^{21}$. Segundo Danieletto (2007), este dispositivo se rompe ao atingir uma força de puxamento especificada, e assim impede que o dano se propague para 0 tubo sendo puxado ( $G A=1)$. Embora eficazes em seus propósitos, as soluções mostradas são claramente disponibilizadas pelos próprios fornecedores dos equipamentos, não havendo incentivo à equipe pelo desenvolvimento próprio desse tipo de dispositivo. Percebe-se, também, que o principal objetivo dos dispositivos em questão é evitar acidentes, e não o desperdício ( $\mathbf{G R}=\mathbf{0})$.

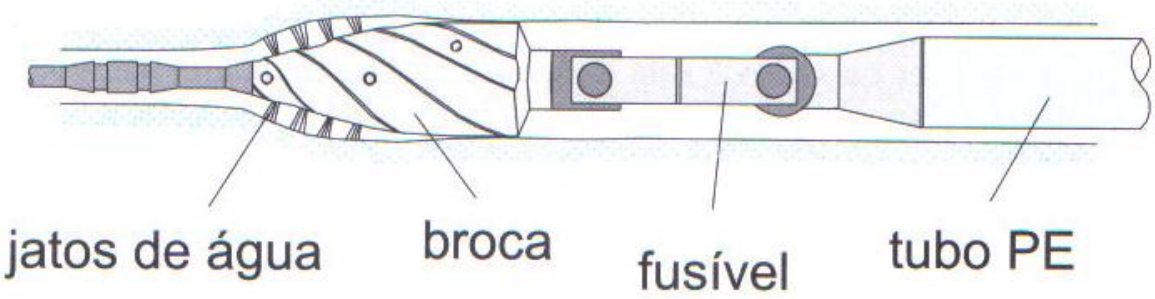

Figura 5-2 - Fusível mecânico para tração de tubulação (DANIELETTO, 2007, p. 344)

- Poka-yoke. A situação dos dispositivos de prevenção de erros (poka-yoke) é similar à dos dispositivos de autonomação descritos acima - eles existem, porém em raras situações. Um exemplo pode ser visto nas soldas de tubos de polietileno por eletrofusão. Esse tipo de solda, segundo Danieletto (2007), emprega uma conexão com resistência elétrica espiralada incorporada, que quando submetida a uma determinada intensidade de corrente elétrica e tempo gera calor a fim de possibilitar a solda da peça ao tubo (Figura 5-3). poka-yoke, no caso, está no código de barras colado à própria conexão, que fornece todos os parâmetros da peça à máquina e impede que se usem parâmetros incorretos por erro de digitação do operador ( $G A=1)$. Porém, trata-se de uma solução vendida pelo fornecedor, e sua aplicação está mais voltada à prevenção de acidentes do que aos objetivos do pensamento enxuto (GR=0).

\footnotetext{
${ }^{21} \mathrm{O}$ furo direcional horizontal é utilizado para instalação de novos tubos sem a abertura de valas (exceto duas pequenas valas nas extremidades). Uma unidade de perfuração com broca abre um furo horizontal no solo de uma extremidade à outra, e em seguida o tubo é puxado através desse furo (DANIELETTO, 2007).
} 


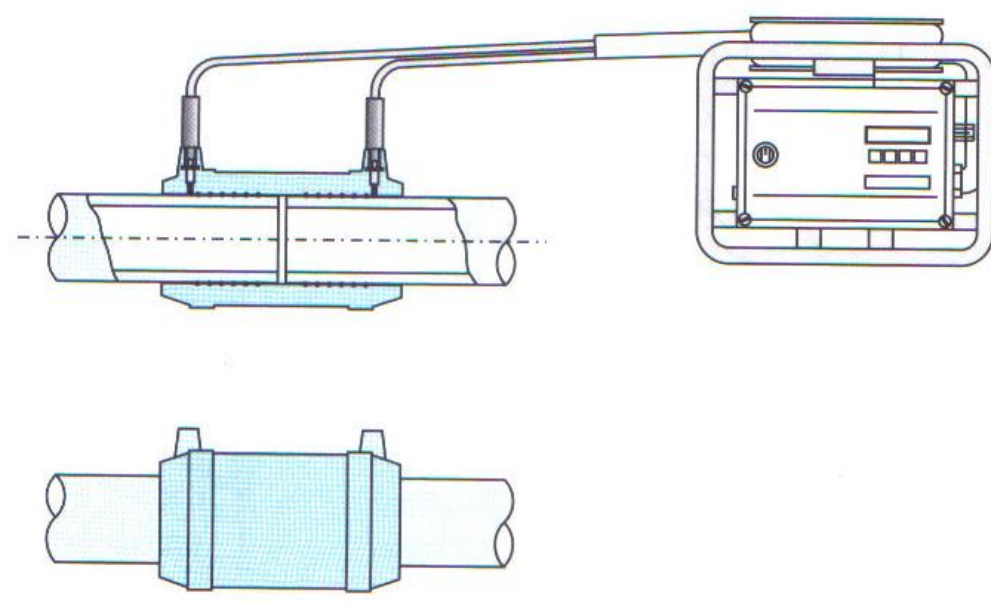

Figura 5-3 - Solda por eletrofusão (DANIELETTO, 2007, p. 264)

\section{Envolvimento}

- Solução de Problemas: Foram apresentadas pelo entrevistado algumas oportunidades em que se fez a investigação de um problema em busca de sua causa-raiz. No entanto, percebe-se que este tipo de investigação só é executado quando ocorre um incidente de trabalho que comprometa ou possa comprometer a saúde, a segurança, ou o meio ambiente $(G A=1)$. Esta prática também tem como foco a prevenção de acidentes. Não é realizado um esforço de investigação similar quando uma atividade deixa de ser desempenhada conforme programado, comprometendo a qualidade, o custo ou o lead time (GR=0).

- Grupos kaizen: Há um prêmio oferecido anualmente àqueles que implantam melhorias mais relevantes em seus processos de trabalho. As iniciativas de melhoria, no entanto, ocorrem de forma esporádica e voluntária, pois não existe a cultura de parar periodicamente para verificar os processos de trabalho e analisar, de forma sistemática, o que pode ser melhorado ( $G A=1)$. O grau de relação é alto, já que muitas das melhorias apresentadas para concorrer ao prêmio visam à eliminação de desperdícios. Um exemplo é a criação de um item de almoxarifado contendo um kit pronto, com todos os materiais necessários para a ligação de um novo cliente, de modo a evitar que as peças tenham que ser coletadas uma a uma a cada nova solicitação (GR=2 - LT).

- Programa de sugestão: Trata-se de uma prática enxuta que se mostrou bem assimilada no processo de construção da Empresa A. Existe um processo 
formal de envio de sugestões disponível a todos os profissionais, com claro feedback da área que recebe a idéia, e as melhores idéias são devidamente premiadas $(\mathbf{G A}=2)$. Percebe-se que muitas das idéias submetidas a este sistema realmente tiveram como motivação a eliminação de desperdícios, o que caracteriza um alto grau de relação (GR=2 - Q/C/LT).

\section{TPEM}

O TPEM e seus três pilares (TPM-AM, TPM-PM e TPM-EM) são, segundo o entrevistado, de difícil aplicação no processo de construção de RDU. Isto porque, na maior parte das vezes, os equipamentos utilizados na construção estão sob responsabilidade das empreiteiras, sendo elas as responsáveis por estabelecer as estratégias de manutenção dos mesmos. À Empresa A, cabe somente fiscalizar se algum equipamento com manutenção inadequada é utilizado no local de obra e, nesse caso, solicitar a troca.

- TPM-AM (manutenção autônoma): $\mathbf{G A}=\mathbf{0} ; \mathbf{G R}=\mathbf{0}$.

- TPM-PM (manutenção preventiva e preditiva): $\mathbf{G A = 0 ; ~} \mathbf{G R = 0 .}$

- TPM-EM (gerenciamento de equipamentos): $\mathbf{G A}=\mathbf{0} ; \mathbf{G R}=\mathbf{0}$.

\section{SBCE}

- SBCE: O entrevistado explicou que a área responsável pelo projeto básico costuma envolver informalmente, no caso de dúvidas, outras áreas para definição de aspectos mais críticos de cada projeto. No entanto, a prática exposta na Seção 3.3.1, das áreas envolvidas trazerem algumas opções de projeto no início do debate para posterior afunilamento, não é executada na empresa $(G A=0)$. Contudo, o entrevistado acredita que algo como o SBCE possa ser implantado futuramente para evitar o excesso de retrabalho despendido (GR=2 - C).

\section{Last Planner}

- Kit Completo: Como regra geral, todas as pré-condições são verificadas antes da execução de qualquer tarefa de construção e isso evita a ocorrência de defeitos. Mas o entrevistado reconhece que às vezes, por pressão de prazo, alguma tarefa acaba sendo executada em condições subótimas, ou seja: sem o projeto detalhado, sem contato com todos os 
envolvidos, com parte dos materiais ainda por vir, etc. $(G A=1)$. O desperdício de tempo e os problemas de qualidade que ocorrem nessas situações é, segundo e entrevistado, reconhecido pela empresa, e existe um trabalho em andamento para sua diminuição, por meio da elaboração e uso de listas de verificação (GR=2 - Q/LT).

- Medição e monitoramento do PPC: A porcentagem executada do plano é constantemente monitorada, como um dos principais indicadores de obra. Porém, o plano em questão não é o plano final de atividades desenvolvido pelo último planejador, como prescreve o sistema Last Planner, e sim o plano macro do projeto $(\mathbf{G A}=\mathbf{0})$. $O$ entrevistado considera interessante a idéia de se basear no planejamento de curto prazo para determinar a porcentagem executada, de forma a saber como as falhas ocorrem durante a execução da obra, para evitar que se repitam os erros que geram paradas (GR=2 - LT).

- Reserva de tarefas executáveis: A transferência dos recursos para executar outra tarefa, quando a que fora planejada se mostra inviável, geralmente ocorre na prática. Mas não há uma previsão sistemática de uma Reserva de Tarefas que podem ser acionadas caso um problema venha a ocorrer com a tarefa programada $(G A=1)$. O entrevistado considera que esta prática seria interessante, pois preveniria a ociosidade dos recursos e evitaria atrasos (GR=2 - LT).

- Lookahead: Percebe-se que existe um responsável por disponibilizar todos os recursos antes da data de execução de cada tarefa de uma obra. No entanto, o responsável analisa quase que exclusivamente os recursos sob responsabilidade da empresa, como materiais e autorizações. Não há controle direto da Empresa A sobre os recursos das empresas contratadas, como equipamentos e mão-de-obra, pois se considera que elas são responsáveis pelos seus próprios recursos $(\mathrm{GA}=1)$. De qualquer forma, o objetivo deste controle é sempre evitar que a falta de recursos atrase o andamento da obra, comprometendo seu lead time (GR=2 - LT).

O Quadro 5-2 apresenta a tabulação dos dados coletados e avaliados para o processo de construção da Empresa A. 
Quadro 5-2 - Tabulação dos dados - Empresa A - Processo de construção

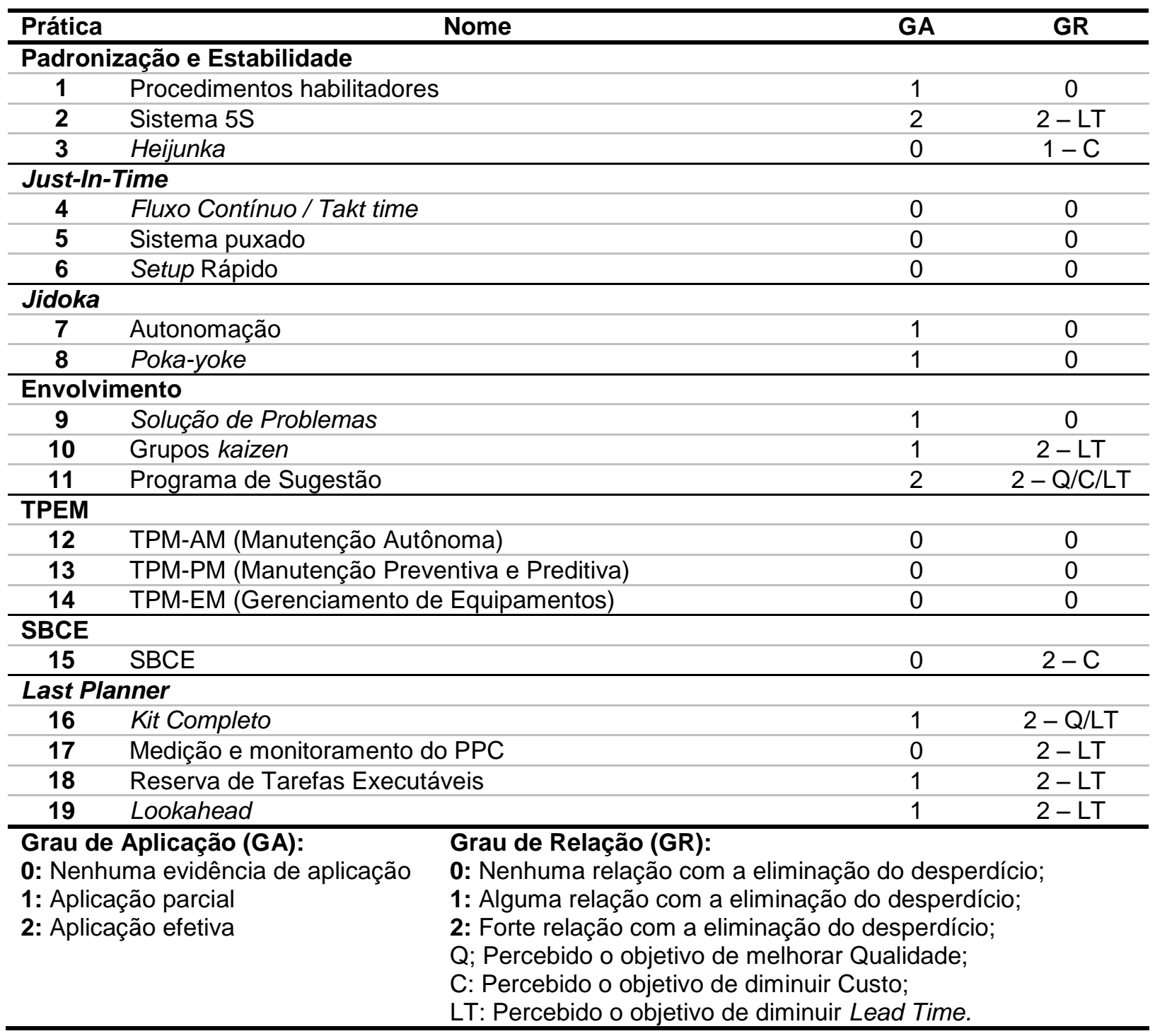

\subsubsection{Processo de manutenção de rede de gás natural}

No caso do processo de manutenção da rede de gás natural da Empresa $A$, a entrevista foi realizada com o gerente de manutenção da empresa.

As atribuições dessa área, segundo o próprio gerente, incluem os processos de campo necessários para garantir a manutenção de todos os equipamentos da rede de gás natural, ou seja: tubulações, estações de regulagem de pressão, conjuntos de medição, válvulas de rede, sistemas de proteção contra corrosão, sistemas de instrumentação e monitoramento remoto, etc. Os principais fornecedores são: a área de expansão, que constrói a rede a ser posteriormente mantida; a área de suprimentos, que disponibiliza os materiais necessários; os provedores de 
informações (patrulhamento de rede, pesquisa de vazamento, call center de emergência, sala de controle de rede), que indicam problemas na rede a serem resolvidos; e os fornecedores de equipamentos, que prestam assistência técnica. Os principais clientes são os próprios consumidores, para quem o serviço de distribuição é mantido com segurança (Quadro 5-3).

Quadro 5-3- Processo de manutenção de redes de gás natural pela Empresa $A$

\begin{tabular}{|c|c|c|}
\hline Fornecedores (e o que fornecem): & Processos atribuídos: & $\begin{array}{l}\text { Clientes (e o que } \\
\text { recebem): }\end{array}$ \\
\hline $\begin{array}{l}\text { Internos: } \\
\text { - Área de expansão (rede a ser } \\
\text { mantida) } \\
\text { - Área de suprimentos (materiais } \\
\text { necessários) } \\
\text { - Provedores de informações } \\
\text { (indicações de problemas na rede) } \\
\text { Externos: } \\
\text { - Fornecedores de equipamentos } \\
\text { (assistência técnica) }\end{array}$ & $\begin{array}{l}\text { Manutenção dos } \\
\text { equipamentos (tubulações, } \\
\text { estações de regulagem de } \\
\text { pressão, conjuntos de } \\
\text { medição, válvulas de rede, } \\
\text { sistemas de proteção contra } \\
\text { corrosão, sistemas de } \\
\text { instrumentação e } \\
\text { monitoramento remoto). }\end{array}$ & $\begin{array}{l}\text { Externos: } \\
\text { - Consumidor } \\
\text { (manutenção da } \\
\text { segurança do } \\
\text { fornecimento) }\end{array}$ \\
\hline
\end{tabular}

Os resultados da entrevista quanto ao grau de aplicação e grau de relação de cada uma das práticas examinadas são apresentados a seguir:

\section{Padronização e estabilidade}

- Procedimentos habilitadores: Da mesma forma que no processo de construção da mesma empresa, foram mostrados exemplos de procedimentos de trabalho simples, padronizados e adequados às atividades. No entanto, de forma similar ao que ocorre no processo de construção, a elaboração envolve mais engenheiros de escritório que os próprios funcionários responsáveis pelas atividades (GA=1). Os procedimentos formais de manutenção contemplam os padrões exigidos de saúde, segurança, meio ambiente e qualidade, mas não revelam maior preocupação quanto ao custo ou lead time $(\mathbf{G R}=\mathbf{0})$.

- Sistema 5S: O sistema baseado no 5S foi implantado de forma corporativa na empresa, englobando tanto o processo de construção como o de manutenção $(G A=2)$. $O$ entrevistado enfatizou a melhoria na produtividade pela diminuição da perda de tempo para procura de ferramentas, materiais e documentos ( $G R=2-L T)$. 
- Heijunka: Diferentemente do que ocorre na construção, a gerência de manutenção mostrou uma maior capacidade de nivelar o volume de trabalho ao longo do ano. Uma das razões é que o programa de manutenção determina a freqüência de execução de cada atividade (mensal, trimestral, etc.), baseado no risco de ocorrências e critérios técnicos. Não há, porém, preocupação em buscar nivelamento do volume de trabalho ou mix de atividades em períodos mais curtos, como ao longo dos dias de uma semana de trabalho ( $G A=1)$. $O$ entrevistado entende que o nivelamento do volume seria interessante para diminuir o custo com a ociosidade e o desperdício; porém, entende que o nivelamento em mix é difícil, uma vez que as freqüências das atividades realizadas são diferentes (GR=1 - C).

\section{Just-In-Time}

- Fluxo Contínuo / Takt time: o entrevistado não explora o conceito de fluxo contínuo, e não vê oportunidade de utilizá-lo em suas atividades. Como as atividades são geralmente executadas em campo, ele acredita não haver como estabelecer um fluxo quando a cada dia se trabalha em um local diferente ( $G A=0 ; G R=0)$.

- Sistema puxado: no caso da manutenção, as atividades são iniciadas geralmente de forma isolada, não dependendo de atividades anteriores. Sendo assim, não há evidências de aplicação do sistema puxado $(\mathrm{GA}=0)$. No entanto, existe uma idéia - embora ainda incipiente - de se criar algo similar ao kanban entre a utilização de materiais para execução das manutenções e a compra dos mesmos, mantendo-se um estoque de segurança para casos de emergência e evitando assim que sejam mantidos estoques desnecessários (GR=1 - C).

- Setup Rápido: Da mesma forma que na construção, a prática de Setup Rápido não é aplicada sistematicamente no processo de manutenção da Empresa $A(G A=0)$. No entanto, o entrevistado reconhece que, como muitas atividades são executadas pela própria equipe da empresa, é possível buscar a minimização do processo de setup entre locais de execução, ou seja, de mudança e outras manobras necessárias entre o término da manutenção em um local até o início em outro local (GR=2 - LT). 


\section{Jidoka}

- Autonomação: O entrevistado citou a válvula de bloqueio automático, utilizada em estações de regulagem de pressão, como exemplo de dispositivo de autonomação em estações de gás. A válvula se aciona automaticamente quando, por um problema no regulador de pressão, a pressão de saída da estação excede um valor determinado. Sempre que isso ocorre, ela bloqueia o fluxo de gás, impedindo que a rede à jusante receba o gás a uma pressão maior do que aquela para a qual foi projetada ( $G A=1)$. Porém, assim como no processo de construção, trata-se de uma solução disponibilizada mundialmente pelos fornecedores de equipamentos, com a finalidade de evitar acidentes, e não foi adotada como resultado de um desenvolvimento próprio nem devido à preocupação com o desperdício (GR=0).

- Poka-yoke. O entrevistado não soube informar sobre nenhum dispositivo que se caracterizasse como poka-yoke ( $G A=0)$. Segundo ele, a garantia que os erros não aconteçam deve vir mais de treinamento da equipe que de soluções de engenharia. Não há uma noção evidente de que, mesmo treinado, qualquer funcionário está sujeito a falhas humanas involuntárias que podem resultar em desperdícios ( $G R=0$ ).

\section{Envolvimento}

$\mathrm{Na}$ Empresa $\mathrm{A}$, as respostas do entrevistado no processo de manutenção se mostraram similares às verificadas no processo de construção para as práticas relacionadas ao Envolvimento, visto que todas as iniciativas apresentadas pela empresa com esse propósito foram implantadas de forma corporativa. Assim, podese admitir que os graus de aplicação e de relação destas práticas também são semelhantes:

- Solução de Problemas: GA=1; GR=0.

- Grupos kaizen: $G A=1 ; G R=2-L T$.

- Programa de sugestão: $G A=2 ; G R=2-Q / C / L T$. 


\section{TPEM}

Diferentemente do que ocorre no processo de construção, os equipamentos utilizados no processo de manutenção são de propriedade da empresa distribuidora, e compõem a própria rede de distribuição.

- TPM-AM (Manutenção Autônoma): Segundo o entrevistado, não faz sentido falar-se em manutenção autônoma no processo de manutenção de redes de gás natural, já que não existe uma equipe de operação que poderia receber essa autonomia. Isso porque, diferentemente do que ocorre em outras indústrias, os equipamentos da rede operam de forma totalmente automatizada, não havendo a necessidade de um operador alocado continuamente em cada equipamento. $A$ intervenção humana se resume às atividades de inspeção e manutenção ( $G A=0 ; G R=0)$.

- TPM-PM (manutenção preventiva e preditiva): $\mathrm{Na}$ Empresa $\mathrm{A}$, a periodicidade da manutenção está focada em confiabilidade, com a aplicação de ferramentas de análise de falha. Porém, segundo o entrevistado, as ferramentas de análise ainda não levam em conta os dados quantitativos reais de falha, recorrendo ao uso de dados qualitativos obtidos da experiência dos envolvidos $(G A=1)$. A perspectiva é que, em um futuro próximo, os dados quantitativos também sejam utilizados, de forma a diminuir o desperdício relativo ao excesso de manutenção, sem comprometer a segurança ( $G R=2-C)$.

- TPM-EM (gerenciamento do equipamento): o desenvolvimento de soluções que exijam menos manutenções futuras ainda não se mostrou uma prioridade na empresa, até porque, conforme informado no item anterior, a freqüência de manutenção ainda não está focada em confiabilidade ( $G A=0)$. No entanto, existe uma tendência futura - após a implantação efetiva do TPM-PM - de se trabalhar nesse pilar, diminuindo os custos de manutenção (GR=2 - C).

\section{SBCE}

- SBCE: O entrevistado do processo de manutenção da Empresa A disse que as equipes responsáveis por novos projetos chegam a consultá-lo algumas vezes - mas não sempre - para verificar se uma nova solução é viável em 
termos de manutenção. No entanto, a idéia de que as áreas envolvidas tragam algumas opções de projeto no início do debate para posterior afunilamento não é explorada na empresa, uma vez que o desenvolvimento do projeto é mantido sob responsabilidade de uma só área $(\mathrm{GA}=0)$. $O$ entrevistado considera a idéia do SBCE interessante e válida para o futuro, pois melhoraria a qualidade da disposição da rede. Porém, ele não crê na sua implantação em curto prazo (GR=1 - Q).

\section{Last Planner}

- Kit Completo: No processo de manutenção, existe uma facilidade maior que no processo de construção de garantir o Kit Completo para se executar as atividades. Isso ocorre porque, na maioria dos casos, a atividade é padronizada, e executada periodicamente. Assim, a prática do Kit Completo se mostra mais evidente, por meio da verificação através de check lists antes do início da atividade, desencorajando aparentes transgressões à regra de assegurar plenas condições de execução ( $(G A=2)$. O objetivo deste controle também está ligado ao pensamento enxuto, pois para o entrevistado a indisponibilidade do Kit Completo aumenta as chances de desperdício com retrabalho, devendo ser evitada (GR=2 - LT).

- Medição e monitoramento do PPC: Na manutenção da Empresa A, embora em menor grau que na construção, também podem surgir imprevistos que impeçam uma manutenção de ser feita no prazo. Um exemplo é o atraso na autorização por parte dos clientes para manutenção de estações em suas propriedades. No entanto, o monitoramento das etapas de uma tarefa de manutenção é feito com base no plano macro, e não no planejamento de curto prazo $(\mathrm{GA}=0)$. $O$ entrevistado considera interessante a idéia de se basear no planejamento micro para determinar a porcentagem executada, de forma a poder identificar em que ponto uma falha ocorreu durante a execução da manutenção e as eventuais pré-condições que não foram atendidas $(\mathbf{G R}=\mathbf{2}-\mathbf{Q} / \mathbf{C} / \mathbf{L T})$.

- Reserva de tarefas executáveis: A entrevista revelou que as atividades de manutenção de rede de gás natural são mais independentes entre si que as de construção. Isso significa que, para execução de uma atividade, 
raramente é necessária a finalização de uma tarefa anterior. Assim, a existência de uma Reserva de Tarefas executáveis é intrínseca ao fluxo de processo da manutenção, não exigindo preocupação por parte da equipe: se qualquer imprevisto impedir que se execute uma manutenção programada, a equipe simplesmente parte para outra manutenção prevista ( $G A=0 ; \mathbf{G R}=0$ ).

- Lookahead: Na manutenção, também existe um responsável por garantir que todos os recursos necessários estejam disponíveis para a atividade, impedindo atrasos no cronograma. Mesmo as equipes de campo de empresas contratadas são controladas por ordens de serviço, o que facilita a sua programação como recurso $(\mathbf{G A}=\mathbf{2})$. $O$ objetivo de executar tal procedimento é evitar atrasos no cronograma e custos extras por ociosidade das equipes (GR=2 $-\mathbf{C} / \mathbf{L T})$.

O Quadro 5-4 apresenta a tabulação dos dados coletados e avaliados para o processo de manutenção da Empresa $A$.

Quadro 5-4 - Tabulação dos dados - Empresa A - Processo de manutenção

\begin{tabular}{|c|c|c|c|}
\hline Prática & Nome & GA & GR \\
\hline \multicolumn{4}{|c|}{ Padronização e Estabilidade } \\
\hline 1 & Procedimentos habilitadores & 1 & 0 \\
\hline 2 & Sistema 5S & 2 & $2-L T$ \\
\hline 3 & Heijunka & 1 & $1-\mathrm{C}$ \\
\hline \multicolumn{4}{|c|}{ Just-In-Time } \\
\hline 4 & Fluxo Contínuo / Takt time & 0 & 0 \\
\hline 5 & Sistema puxado & 0 & $1-\mathrm{C}$ \\
\hline 6 & Setup Rápido & 0 & $2-L T$ \\
\hline \multicolumn{4}{|l|}{ Jidoka } \\
\hline 7 & Autonomação & 1 & 0 \\
\hline 8 & Poka-yoke & 0 & 0 \\
\hline \multicolumn{4}{|c|}{ Envolvimento } \\
\hline 9 & Solução de Problemas & 1 & 0 \\
\hline 10 & Grupos kaizen & 1 & $2-\mathrm{LT}$ \\
\hline 11 & Programa de Sugestão & 2 & $2-\mathrm{Q} / \mathrm{C} / \mathrm{LT}$ \\
\hline \multicolumn{4}{|l|}{ TPEM } \\
\hline 12 & TPM-AM (Manutenção Autônoma) & 0 & 0 \\
\hline 13 & TPM-PM (Manutenção Preventiva e Preditiva) & 1 & $2-C$ \\
\hline 14 & TPM-EM (Gerenciamento de Equipamentos) & 0 & $2-C$ \\
\hline \multicolumn{4}{|c|}{ 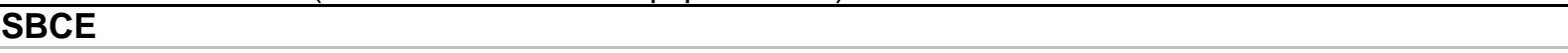 } \\
\hline 15 & SBCE & 0 & $1-Q$ \\
\hline \multicolumn{4}{|c|}{ Last Planner } \\
\hline 16 & Kit Completo & 2 & $2-\mathrm{LT}$ \\
\hline 17 & Medição e monitoramento do PPC & 0 & $2-Q / C / L T$ \\
\hline 18 & Reserva de Tarefas & 0 & 0 \\
\hline 19 & Lookahead & 2 & $2-\mathrm{C} / \mathrm{LT}$ \\
\hline
\end{tabular}




\begin{tabular}{ll}
\hline Grau de Aplicação (GA): & Grau de Relação (GR): \\
0: Nenhuma evidência de aplicação & 0: Nenhuma relação com a eliminação do desperdício; \\
1: Aplicação parcial & 1: Alguma relação com a eliminação do desperdício; \\
2: Aplicação efetiva & 2: Forte relação com a eliminação do desperdício; \\
& Q; Percebido o objetivo de melhorar Qualidade; \\
& C: Percebido o objetivo de diminuir Custo; \\
& LT: Percebido o objetivo de diminuir Lead Time. \\
\hline
\end{tabular}

\subsection{Empresa B - Distribuição de água}

A Empresa B é uma empresa de saneamento básico, de capital misto, com o governo como acionista majoritário. Segundo seu próprio site, conta com cerca de 17.000 profissionais e abastece mais de 26 milhões de pessoas. Sua atuação inclui toda a cadeia de fornecimento da água, conforme descrita na Seção 2.2.1, além do processo de coleta e tratamento de esgotos. Porém, as entrevistas se limitaram ao escopo desta dissertação e contemplaram exclusivamente a atividade de distribuição de água.

\subsubsection{Processo de construção de redes de distribuição de água}

Para a coleta de dados sobre o processo de construção de redes de água, foi entrevistado o encarregado de obras de um pólo regional de manutenção e implantação da Empresa B. Segundo o entrevistado, o pólo regional para o qual ele trabalha é responsável por toda a manutenção e implantação de redes de água até $400 \mathrm{~mm}$ de diâmetro em sua área de atuação, enquanto redes de diâmetro maior são de responsabilidade de outra unidade de negócio específica.

As atribuições do entrevistado incluem todo o trabalho de rua necessário para a implantação (construção) de redes, enquanto outra equipe cuida da manutenção das mesmas redes. Diferentemente do que ocorre na Empresa A, o projeto executivo já é fornecido pronto pela área de Engenharia, sendo sua responsabilidade somente implantá-lo. Assim, o principal fornecedor da área é a própria Engenharia, enquanto os consumidores finais e a área de manutenção são seus clientes (Quadro 5-5). 
Quadro 5-5 - Processo de construção de redes de água pela Empresa $B$

\begin{tabular}{lll}
\hline Fornecedores (e o que fornecem): & Processos atribuídos: & Clientes (e o que recebem): \\
\hline Internos: & $\bullet$ Obtenção de materiais & Internos: \\
- Engenharia (projeto executivo) & - Construção de rede & $\bullet$ Manutenção (rede a ser \\
- Suprimentos (materiais) & - Ligação de & mantida) \\
Externos: & consumidores & Externos: \\
Empreiteira (mão-de-obra e & & $\bullet$ Consumidor final (água) \\
equipamentos) & & \\
\hline
\end{tabular}

Segue o relatório da coleta de dados e as avaliações dos graus de aplicação (GA) e relação (GR) de cada prática enxuta, de forma análoga à apresentada para a Empresa A na Seção 5.1.1:

\section{Padronização e estabilidade}

- Procedimentos habilitadores: O entrevistado mostrou que os trabalhos seguem procedimentos simples, desenvolvidos na forma de "passo a passo", porém desenvolvidos por uma área específica para toda a empresa. A centralização dos procedimentos se mostra necessária devido à necessidade legal de unificação dos preços, por ser uma empresa predominantemente estatal e sujeita às leis de licitação $(G A=1)$. Segundo o entrevistado, a preocupação central reside na garantia da qualidade, mas a questão da redução do desperdício começou também a ser levada em conta na elaboração dos procedimentos há pouco tempo (GR=1 - Q/C/LT).

- Sistema 5S: Existe um processo de 5 S ainda em implantação, contando inclusive com gestão visual por meio de quadros atualizados. No entanto, ainda se nota uma desorganização nos documentos manuseados pela equipe, o que mostra que não existe uma gestão visual consolidada ( $G A=1)$. A motivação para o $5 \mathrm{~S}$, segundo o entrevistado, é mostrar os problemas e possibilitar sua prevenção, o que está de acordo com o pensamento enxuto (GR=2 $-Q / C / L T)$.

- Heijunka: O entrevistado mostrou que há metas anuais e mensais para implantação de novas redes e ligações de consumidores, e que há certo nivelamento entre os meses. No entanto, em certos períodos, podem ocorrer fatores externos que prejudiquem o nivelamento, como a falta de equipes 
devido ao encerramento de contratos e a conseqüente necessidade de aceleração no período seguinte $(\mathbf{G A}=1)$. O nivelamento em volume busca evitar os desperdícios de pessoal parado, além de cumprir com a necessidade legal de parcelar de forma equilibrada os desembolsos contratuais. Porém, assim como na Empresa $A$, não foi verificada nenhuma iniciativa de nivelamento em mix (GR=1 - C).

\section{Just-In-Time}

- Fluxo Contínuo / Takt time: o entrevistado afirma existirem parcerias com empreiteiras para racionalização dos processos, mas não a ponto de eliminar desperdícios ou de estabelecer ritmos de trabalho $(\mathbf{G A}=0)$. entrevistado também não acredita que esse tipo de fluxo se aplica ao seu meio de atuação, estando mais restrito a atividades de manufatura ( $G R=0$ ).

- Sistema puxado: o entrevistado não aplica o sistema puxado em suas atividades $(\mathrm{GA}=\mathbf{0})$. Ele também desconhece uma forma de aplicação deste sistema já que, no início da obra de construção, a equipe já leva tudo o que necessita para toda sua duração. Neste caso, aquilo que é levado com grande antecipação acaba sendo "empurrado" á obra (GR=0).

- Setup Rápido: O Setup Rápido não é aplicado no processo de construção da Empresa $B(G A=0)$. $O$ entrevistado também considera que a situação levantada pela Empresa A como uma adaptação do conceito de Setup - ou seja, a redução do tempo para a mudança de uma equipe que termina o serviço em um local e que deve iniciar o próximo em outro local (ver Seção 5.1.1) - não é aplicável na Empresa B. Ele alega que as equipes de construção de redes de água costumam se manter no mesmo local durante todo um dia de trabalho, não se deslocando entre diferentes frentes de obra (GR=0).

\section{Jidoka}

- Autonomação. O entrevistado explicou que os equipamentos utilizados pelas equipes de construção da Empresa B são bastante básicos, resumindo-se geralmente a: compressor, retroescavadeira, bate-estaca e cortador de asfalto (Figura 5-4). Ele desconhece algum dispositivo capaz de interromper a atuação destes equipamentos no caso de defeitos ( $G A=0)$, como também 
não conhece nenhuma iniciativa em andamento na empresa com o intuito de implementar dispositivos que tenham essa função (GR=0).
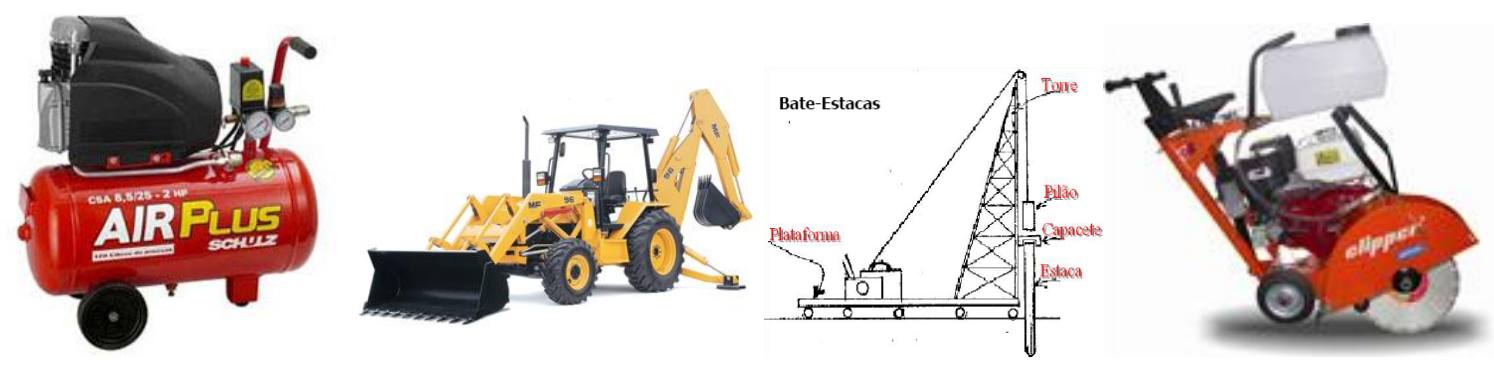

Figura 5-4 - Equipamentos básicos de construção de redes de água - compressor, retroescavadeira, bate-estacas e cortador de solo

- Poka-yoke: O entrevistado não soube informar sobre a existência de dispositivos poka-yoke nos equipamentos ilustrados na Figura 5-4, capazes de atuar na prevenção de $\operatorname{erros}^{22}(\mathbf{G A = 0})$, nem atuação por parte da empresa para que estes dispositivos sejam desenvolvidos e instalados para eliminação de desperdício (GR=0).

\section{Envolvimento}

- Solução de Problemas: O entrevistado afirma haver iniciativas de investigação e solução de problemas quando estes desencadeiam em acidentes de trabalho. Como estas iniciativas geralmente envolvem somente pessoas com cargos relativos à segurança do trabalho, ele desconhece o método de investigação utilizado $(\mathbf{G A = 1})$. O foco desta investigação está nos problemas relacionados à segurança, e não em problemas que possam gerar outros tipos de desperdício (GR=0).

- Grupos kaizen: O entrevistado afirma que a empresa vem implantando, nos últimos anos, os chamados Grupos de Melhoria de Processo (GMP), responsáveis por avaliar cada processo da empresa e buscar melhorias. No entanto, diferentemente dos Grupos kaizen apresentados na Seção 3.2.4, o pessoal de campo que executa a atividade não costuma ser envolvido, e geralmente é apenas informado quando a decisão pela implantação de uma nova melhoria já está tomada $(\mathbf{G A = 1})$. $\mathrm{O}$ assunto abordado pelos membros

${ }^{22}$ Os equipamentos como a retroescavadeira e o cortador de solo provavelmente têm dispositivos de segurança originais de fábrica. No entanto, o entrevistado não soube informar sobre a existência ou não dos mesmos. 
de um GMP é a melhoria de processos, o que caracteriza um alto grau de relação com as motivações do pensamento enxuto (GR=2 - Q/C/LT).

- Programa de sugestão: O entrevistado apresentou o programa de sugestão da empresa, disponibilizado a todos empregados de forma on-line pela própria intranet da empresa ( $\mathrm{GA}=2$ ). Muitas das idéias implantadas têm foco em melhorias de processos (GR=2 - $\mathbf{Q} / \mathbf{C} / \mathbf{L T}$ ).

\section{TPEM}

- TPM-AM (Manutenção Autônoma): O entrevistado informa que os operadores dos equipamentos mostrados na Figura 5-4 não se envolvem no processo de análise e manutenção dos equipamentos $(\mathrm{GA}=0$ ). Ele também não acredita na possibilidade de implantação da Manutenção Autônoma, pois alega que existem legislações trabalhistas que impedem que os trabalhadores executem duas funções diferentes (GR=0).

- TPM-PM (Manutenção Preventiva e Preditiva): Foi mostrado que os contratos exigem das empreiteiras que as mesmas tenham planos de manutenção preventiva, preditiva e corretiva dos equipamentos. Os mesmos, no entanto não especificam a freqüência das intervenções de manutenção. Também não é verificado, pela empresa contratante, se o plano de manutenção é realmente obedecido $(\mathbf{G A}=\mathbf{0})$. $O$ entrevistado acredita que, em contratos novos, possa ser aplicado um maior controle destes itens para evitar quebras e conseqüentes desperdícios de tempo ( $G R=1-L T)$.

- TPM-EM (Gerenciamento de Equipamentos): Não foram encontradas soluções para melhoria dos equipamentos apresentados na Figura 5-4, possibilitando menor necessidade de manutenção $(\mathbf{G A}=\mathbf{0})$. A empresa também não se envolve no processo de manutenção destes equipamentos que são de propriedade das empreiteiras, o que dificulta a aplicação desta prática (GR=0).

\section{SBCE}

- SBCE: O entrevistado explicou que o projeto é executado por outra área da empresa (Engenharia) sendo que a sua área só é acionada quando o projeto 
já está pronto. Em alguns casos, as equipes de construção levantam necessidades de alteração na hora da execução, retornando o projeto para revisão da Engenharia. Isto caracteriza, segundo a Seção 3.3.2, uma Engenharia Serial Baseada em Pontos, e não uma Engenharia Simultânea Baseada em Conjuntos ( $(\mathrm{A}=\mathbf{0})$. Ele acredita que, no caso de projetos simples como os que ele executa, não é necessário o envolvimento de outras áreas no início, mas que a prática do SBCE seria interessante em projetos grandes (GR=1).

\section{Last Planner}

- Kit Completo: Todas as pré-condições são verificadas antes da execução de qualquer tarefa de construção, por meio de um check-list antes do início da obra. Este processo já está em prática hoje em dia (GA=2). O desenvolvimento do check-list deveu-se à necessidade de prevenção de desperdícios de tempo, que antes eram freqüentes, na busca de recursos (materiais, equipamentos, etc.) faltantes (GR=2 - LT).

- Medição e monitoramento do PPC: A execução do plano é monitorada, mas apenas seguindo o plano macro de longo prazo, já que não existe a figura do último planejador $(\mathbf{G A}=\mathbf{0})$. A empresa não pretende adotar a idéia do monitoramento da execução do plano com base no planejamento de curto prazo (GR=0).

- Reserva de Tarefas: É mantido um estoque de recursos, principalmente no caso dos materiais, para os próximos três meses de obra ( $G A=2)$. Isso, no entanto, destoa da idéia do Last Planner criado por Ballard (2000), para quem um estoque de duas semanas seria suficiente, sendo que mais que isso configura no desperdício na forma de estoque (Seção 3.4.1). Sendo assim, não se pode dizer que a Reserva de Tarefas da Empresa B realmente leve em conta a redução de todos os tipos de desperdício, embora a questão do desperdício de tempo possa ser percebida (GR=1 LT).

- Lookahead: A Empresa B prevê os recursos sob responsabilidade da empresa no processo de planejamento das obras, como materiais e autorizações, mas não os recursos sob responsabilidade das empreiteiras, 
como equipamentos e mão-de-obra $(G A=1)$. Na previsão das necessidades dos primeiros, a preocupação com a diminuição de lead time está presente (GR=2 - LT).

O Quadro 5-6 apresenta a tabulação dos dados coletados e avaliados para o processo de construção da Empresa B.

Quadro 5-6 - Tabulação dos dados - Empresa B - Processo de construção

\begin{tabular}{|c|c|c|c|c|}
\hline \multirow{2}{*}{\multicolumn{5}{|c|}{$\begin{array}{l}\text { Prática } \\
\text { Padronização e Estabilidade }\end{array}$}} \\
\hline & & & & \\
\hline 1 & \multicolumn{2}{|l|}{ Procedimentos habilitadores } & 1 & $1-\mathrm{Q} / \mathrm{C} / \mathrm{LT}$ \\
\hline 2 & \multicolumn{2}{|l|}{ Sistema 5S } & 1 & $2-Q / C / L T$ \\
\hline 3 & \multicolumn{2}{|l|}{ Heijunka } & 1 & $1-\mathrm{C}$ \\
\hline \multicolumn{5}{|c|}{ Just-In-Time } \\
\hline 4 & \multicolumn{2}{|l|}{ Fluxo Contínuo / Takt time } & 0 & 0 \\
\hline 5 & \multicolumn{2}{|l|}{ Sistema puxado } & 0 & 0 \\
\hline 6 & \multicolumn{2}{|l|}{ Setup Rápido } & 0 & 0 \\
\hline \multicolumn{5}{|l|}{ Jidoka } \\
\hline 7 & \multicolumn{2}{|l|}{ Autonomação } & 0 & 0 \\
\hline 8 & \multicolumn{2}{|l|}{ Poka-yoke } & 0 & 0 \\
\hline \multicolumn{5}{|c|}{ Envolvimento } \\
\hline 9 & \multicolumn{2}{|l|}{ Solução de Problemas } & 1 & 0 \\
\hline 10 & \multicolumn{2}{|l|}{ Grupos kaizen } & 1 & $2-Q / C / L T$ \\
\hline 11 & \multicolumn{2}{|l|}{ Programa de Sugestão } & 2 & $2-Q / C / L T$ \\
\hline \multicolumn{5}{|l|}{ TPEM } \\
\hline 12 & \multicolumn{2}{|c|}{ TPM-AM (Manutenção Autônoma) } & 0 & 0 \\
\hline 13 & \multicolumn{2}{|c|}{ TPM-PM (Manutenção Preventiva e Preditiva) } & 0 & $1-L T$ \\
\hline 14 & \multicolumn{2}{|c|}{ TPM-EM (Gerenciamento de Equipamentos) } & 0 & 0 \\
\hline \multicolumn{5}{|l|}{ SBCE } \\
\hline 15 & \multicolumn{2}{|l|}{ SBCE } & 0 & $1-\mathrm{LT}$ \\
\hline \multicolumn{5}{|c|}{ Last Planner } \\
\hline 16 & \multicolumn{2}{|c|}{ Kit Completo } & 2 & $2-L T$ \\
\hline 17 & \multicolumn{2}{|c|}{ Medição e monitoramento do PPC } & 0 & 0 \\
\hline 18 & \multicolumn{2}{|l|}{ Reserva de Tarefas } & 2 & $1-\mathrm{LT}$ \\
\hline 19 & \multicolumn{2}{|l|}{ Lookahead } & 1 & $2-L T$ \\
\hline \multicolumn{2}{|c|}{$\begin{array}{l}\text { Grau de Aplicação (GA): } \\
\text { 0: Nenhuma evidência de aplicação } \\
\text { 1: Aplicação parcial } \\
\text { 2: Aplicação efetiva }\end{array}$} & \multicolumn{3}{|c|}{$\begin{array}{l}\text { Grau de Relação (GR): } \\
\text { 0: Nenhuma relação com a eliminação do desperdício; } \\
\text { 1: Alguma relação com a eliminação do desperdício; } \\
\text { 2: Forte relação com a eliminação do desperdício; } \\
\text { Q; Percebido o objetivo de melhorar Qualidade; } \\
\text { C: Percebido o objetivo de diminuir Custo; } \\
\text { LT: Percebido o objetivo de diminuir Lead Time. }\end{array}$} \\
\hline
\end{tabular}

\subsubsection{Processo de manutenção de redes de distribuição de água}

Para a coleta de dados sobre o processo de manutenção de redes de água, foi entrevistado o responsável pelas atividades de manutenção de redes e ramais de água em um pólo regional de manutenção e implantação da Empresa B. 
O entrevistado explicou que sua atuação se limita às redes e ramais de água da região, estando as válvulas e estações e as redes de esgoto sob responsabilidade de outros profissionais. Seu principal cliente é o próprio consumidor de água, que precisa ter seu suprimento de água mantido com segurança. Outro cliente é a própria empresa, que solicita manutenções preventivas para localizar vazamentos e assim combater as perdas de água das redes. Entre os fornecedores, estão: a equipe de construção, que disponibiliza a rede a ser mantida; a Unidade de Materiais, que provê os materiais necessários; o informante (consumidor, unidade de engenharia, etc.), que indica os problemas na rede a serem sanados; e a empreiteira contratada especificamente para as atividades de manutenção.

Quadro 5-7 - Processo de manutenção de redes de água pela Empresa B

\begin{tabular}{|c|c|c|}
\hline Fornecedores (e o que fornecem): & Processos atribuídos: & Clientes (e o que recebem): \\
\hline $\begin{array}{l}\text { Internos: } \\
\text { - Área de expansão (rede a ser mantida) } \\
\text { - Unidade de Materiais (materiais } \\
\text { necessários) } \\
\text { - Informante (indicações de problemas na } \\
\text { rede) }\end{array}$ & $\begin{array}{l}\text { Manutenção das redes } \\
\text { e ramais de água. }\end{array}$ & $\begin{array}{l}\text { Externos: } \\
\text { - Consumidor (manutenção } \\
\text { da segurança do } \\
\text { fornecimento) } \\
\text { - A própria empresa } \\
\text { (combate a perdas) }\end{array}$ \\
\hline $\begin{array}{l}\text { Externos: } \\
\text { - Empreiteira responsável (serviço de } \\
\text { manutenção) }\end{array}$ & & \\
\hline
\end{tabular}

O relatório dos dados coletados sobre o processo de manutenção da rede na Empresa B é apresentado a seguir.

\section{Padronização e estabilidade}

- Procedimentos habilitadores: Da mesma forma que no processo de construção desta empresa, os trabalhos seguem procedimentos simples, elaborados de forma centralizada com participação de representantes de todos os pólos regionais, mas sem envolvimento daqueles que realmente executam a atividade em campo $(G A=1)$. Segundo o entrevistado, a produtividade não é considerada uma preocupação central na elaboração dos procedimentos, os quais são focados principalmente na qualidade e na segurança do serviço (GR=0).

- Sistema 5S: O entrevistado informou que existem procedimentos específicos que explicam à contratada como esta deve organizar seu canteiro de obras. 
Isso, porém, não se caracteriza como evidência de aplicação do Sistema 5S, pois se limita a exigir locais diferentes para instalação cada atividade (almoxarifado de peças, armazenamento de máquinas, etc.), mas não especifica como cada um destes lugares deve ser arrumado $(G A=0)$. O nível de organização exigido está mais ligado a exigências da norma ISO 9000, e não à oportunidade de eliminar problemas gerados pela falta de organização (GR=0).

- Heijunka: O entrevistado afirma que a mesma equipe é responsável, em sua área de atuação, pelas tarefas de manutenção preventiva, que são programadas, e pelas de manutenção corretiva, que são demandadas pelos consumidores. Assim, ele procura estabelecer certo nivelamento em volume de trabalho por meio do encaixe de manutenções preventivas em períodos de menor demanda por serviços de manutenções corretivas (feriados, por exemplo). Quanto ao nivelamento em mix, não foi encontrada nenhuma iniciativa a respeito $(G A=1)$. $O$ entrevistado entende que o nivelamento em volume é buscado pela empresa e diminui os custos, mas não vê oportunidade em explorar a prática do nivelamento em mix, devido à grande variedade das atividades que precisam ser executadas ( $G R=1-C)$.

\section{Just-In-Time}

- Fluxo Contínuo / Takt time: o entrevistado desconhece qualquer aplicação deste conceito em atividades do processo de manutenção de redes de água $(G A=0)$. Ele também não vê qualquer oportunidade de aplicação deste conceito no contexto em questão, pela própria característica dinâmica do processo, em que cada dia se executam diferentes atividades e em diferentes locais. (GR=0).

- Sistema puxado: Não existe, segundo o entrevistado, aplicação do sistema puxado nas atividades de manutenção preventiva sob sua responsabilidade $(G A=0)$. $O$ entrevistado também não vê como aplicá-lo, uma vez que a compra de materiais utilizados na manutenção é promovida por outra unidade, que "empurra" os materiais comprados para uso em atividades de sua área (GR=0). 
- Setup Rápido: No processo de manutenção das redes de água, a Empresa B aplica uma espécie de Setup Rápido na execução das diversas tarefas de manutenção programadas para um dia específico. O sistema de informação que realiza a programação da manutenção divide as tarefas conforme posição geográfica entre as doze equipes disponíveis, de forma que uma mesma equipe realize somente tarefas em locais próximos em um mesmo dia (Figura 5-5). Embora essa forma de divisão diminua os desperdícios com o deslocamento, não se pode dizer que a prática de Setup Rápido seja aplicada como um todo, já que as atividades de desmobilização e mobilização entre as sucessivas tarefas não são devidamente analisadas (GA=1). O Grau de Relação, porém, se mostra alto já que a preocupação de reduzir o desperdício de tempo com deslocamentos é bastante acentuada (GR=2 - LT).

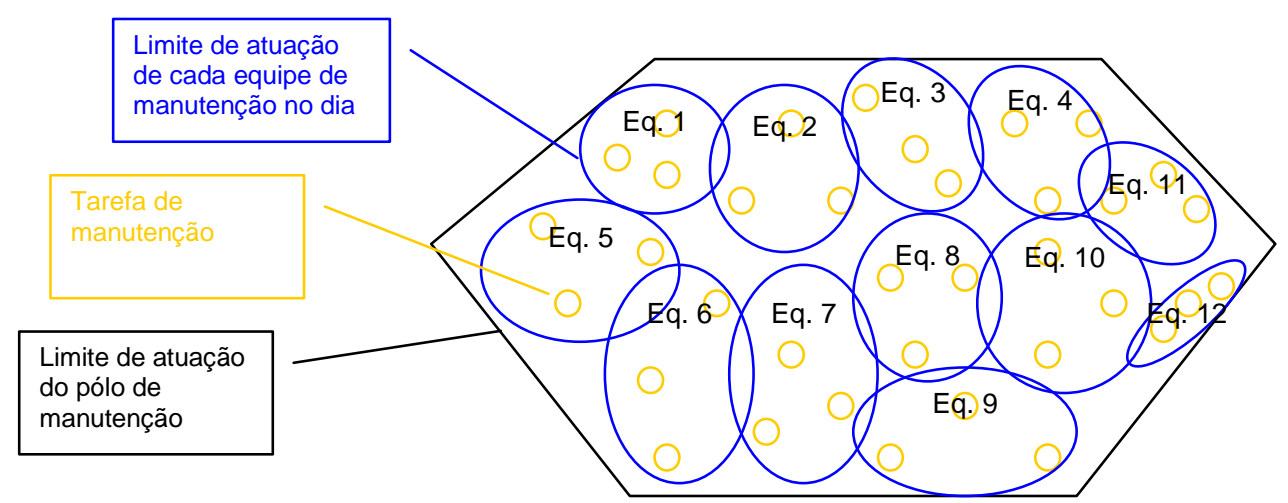

Figura 5-5 - Divisão das tarefas de manutenção entre equipes na Empresa $B$

\section{Jidoka}

- Autonomação: O entrevistado citou alguns equipamentos de controle de vazão que são telemetrizados e controlados à distância, com válvulas que são desligadas e ligadas conforme a necessidade, sem a necessidade de intervenção humana. No caso da ocorrência de uma falha, é enviado um alarme ao Centro de Controle Operacional (Figura 5-6), que aciona uma equipe de campo. No entanto, de forma análoga ao que ocorre na Empresa A, tratam-se de soluções desenvolvidas e adotadas por fornecedores e aplicadas internacionalmente em redes de água, não sendo resultado do desenvolvimento da própria empresa ( $G A=1)$. Não há, por parte da empresa, nenhuma iniciativa de desenvolvimento de dispositivos que possam ser caracterizados como autonomação ( $G R=0$ ). 


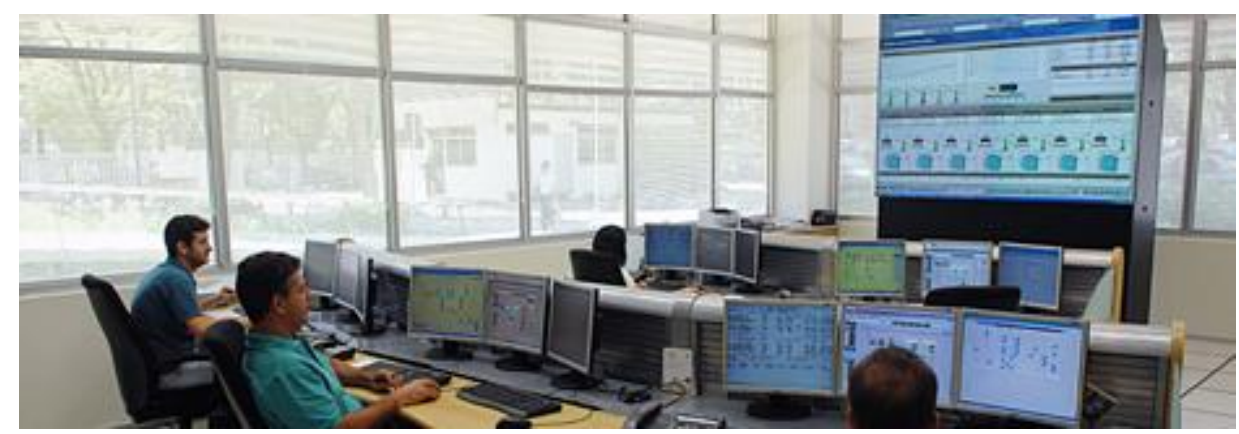

Figura 5-6 - Centro de Controle Operacional da Empresa B (material disponibilizado pela empresa)

- Poka-yoke: O entrevistado não conhece nenhum dispositivo de prevenção de erros que seja aplicado no processo de manutenção $(G A=0)$. Também não é conhecida nenhuma iniciativa por parte da empresa com o propósito de desenvolvê-los (GR=0).

\section{Envolvimento}

A situação das práticas de envolvimento no processo de manutenção é comparável à do processo de construção, pois a implementação das mesmas ocorre de forma corporativa na empresa. Sendo assim, os graus de aplicação e de relação de tais práticas no processo de manutenção são os mesmos do processo de construção, quais sejam:

- Solução de Problemas: GA=1; GR=0.

- Grupos kaizen: $G A=1 ; G R=2-Q / C / L T$.

- Programa de sugestão: $G A=2 ; G R=2-Q / C / L T$.

\section{TPEM}

- TPM-AM (Manutenção Autônoma): A prática de manutenção autônoma não é aplicada no processo de manutenção da Empresa $B(G A=0)$. Sua aplicabilidade neste contexto também é questionada, por não haver propriamente um operador de cada equipamento que poderia assumir as tarefas de Manutenção Autônoma. Quanto aos profissionais do processo de manutenção, estes já lidam com manutenção como sua atividade diária principal (GR=0). 
- TPM-PM (Manutenção Preventiva e Preditiva): A manutenção preventiva existe no processo de manutenção da Empresa $B$, da seguinte maneira: a equipe verifica os locais em que há maiores vazamentos, com base no cálculo da diferença entre o volume que entra na rede e a soma dos volumes medidos nas instalações dos clientes, e então executa análises para identificar os trechos com possíveis defeitos. Não há, no entanto, um critério de priorização dos trechos a serem trocados baseado em análises de confiabilidade $(\mathrm{GA}=\mathbf{1})$. Quanto à relação com a produção enxuta, pode-se dizer que o critério de manutenção leva em conta a importância de reduzir desperdícios, no caso, representados pelo desperdício de água por vazamento (custo). Porém, esta relação não é plena, já que outros tipos de desperdício como de mão-de-obra, equipamentos, materiais, etc. não são considerados $(\mathrm{GA}=1-\mathrm{C})$.

- TPM-EM: O entrevistado afirma serem empenhados esforços no sentido de desenvolver equipamentos que exijam menos manutenção. Tais esforços, no entanto, são exclusivos da área central de Engenharia da empresa, sem o envolvimento do pessoal de campo, que poderia contribuir através da experiência e da informação sobre as principais dificuldades encontradas durante a execução da atividade ( $G A=1)$. Este critério está começando a ser levado em conta na compra de equipamentos, para diminuir os custos, embora o entrevistado admita que o principal critério considerado continue sendo o preço ( $G R=1)$.

\section{SBCE}

- SBCE: Assim como no processo de construção, o envolvimento da equipe de manutenção só ocorre quando o projeto já está pronto, caracterizando a ocorrência de uma Engenharia Serial Baseada em Pontos, e não uma Engenharia Simultânea Baseada em Conjuntos ( $\mathrm{GA}=\mathbf{0})$. O entrevistado considera que seu envolvimento desde o início seria difícil pelo sistema de desenvolvimento atualmente adotado pela empresa, em que o projeto não é executado pelo pólo de implantação e manutenção (GR=0). 


\section{Last Planner}

- Kit Completo: O entrevistado considera que o contrato já subentende que a contratada dispõe de todos os recursos necessários para a execução da atividade. De fato, no processo de manutenção, a padronização das atividades e o uso de check lists fazem com que o Kit Completo esteja geralmente disponível ( $G A=2)$. Assim, as equipes de manutenção perdem menos tempo com a procura de recursos (GR=2 - LT).

- Medição e monitoramento do PPC: O monitoramento mensal das manutenções executadas na rede de água está baseado no planejamento macro, e não no plano do Last Planner $(G A=0)$. O entrevistado não considera necessária a diferenciação de planos elaborados nos níveis macro e micro para o controle da execução de atividades ( $(\mathbf{R}=\mathbf{0})$.

- Reserva de Tarefas: O entrevistado não estabelece uma Reserva de Tarefas de manutenção para execução, pois segue a programação já estipulada das mesmas. No caso de imprevisto, ele apenas adianta uma atividade que seria executada no dia seguinte ( $G A=0 ; G R=0)$.

- Lookahead: Na manutenção, os recursos de mão-de-obra e equipamentos são disponibilizados pela empreiteira contratada para execução da atividade. No caso dos materiais, o fornecimento cabe à empresa contratante (Empresa B), mas por meio da área responsável pelo almoxarifado, e não da área que gerencia a manutenção. Assim, o entrevistado acredita que a prática do Lookahead não seria aplicável no processo de manutenção da Empresa $B(G A=0 ; G R=0)$.

No Quadro 5-8, pode-se verificar a tabulação dos dados coletados e avaliados para o processo de manutenção da Empresa B. 
Quadro 5-8 - Tabulação dos dados - Empresa B - Processo de manutenção

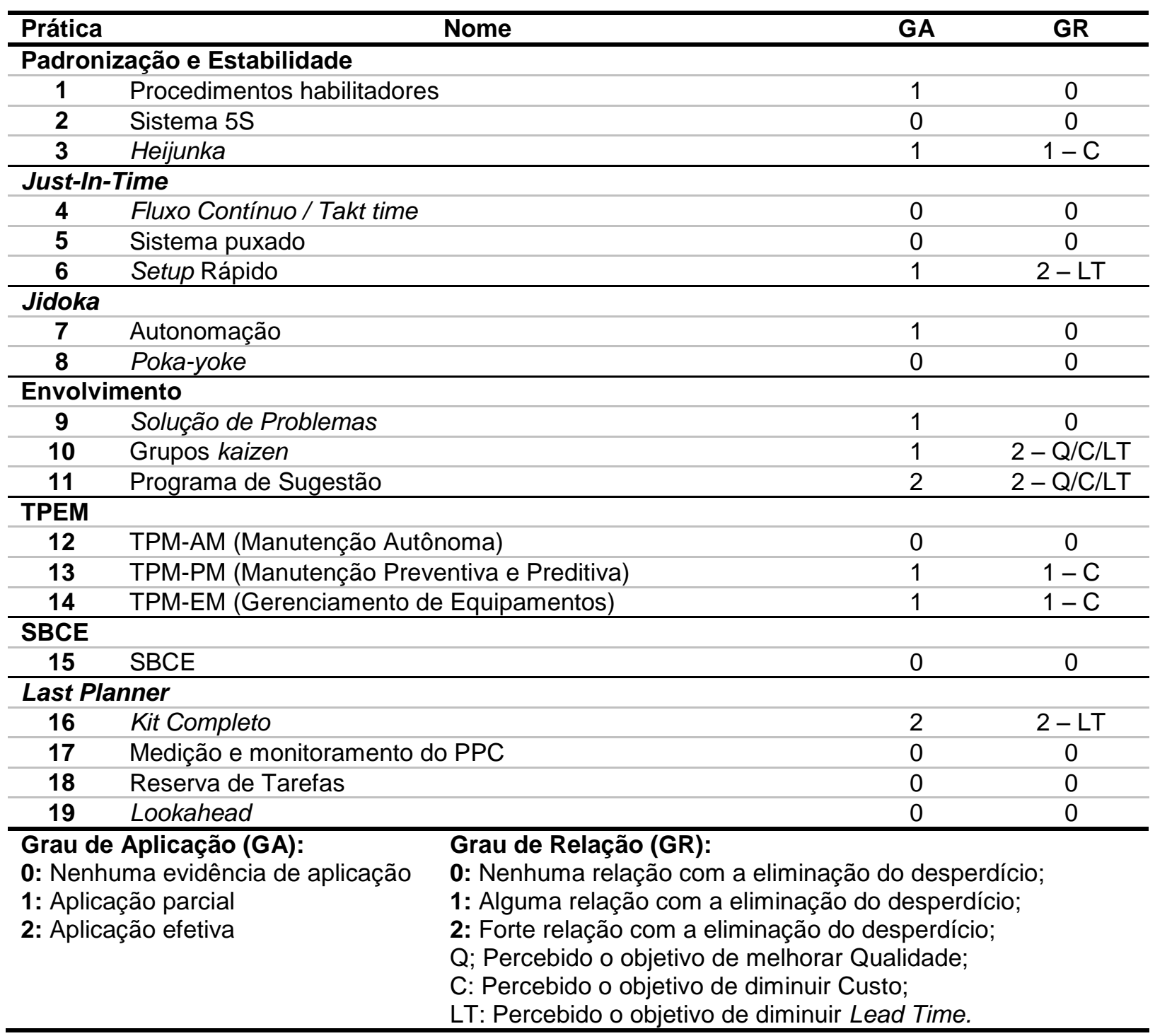

\subsection{Empresa C - Distribuição de energia elétrica}

A Empresa $C$ é uma distribuidora de energia elétrica, que tem em comum com a Empresa $\mathrm{A}$ a sua história de atuação centenária (desde o final do século XIX) e a privatização recente (na década de 1990). Atua em 24 municípios e distribui energia elétrica a 5,6 milhões de unidades consumidoras, contando com cerca de 4.000 empregados $^{23}$.

As redes de distribuição de energia elétrica da Empresa $C$ estão dispostas tanto em posição aérea (penduradas em postes) quanto enterrada. No entanto, para possibilitar uma adequada comparação com as Empresas A e B - cujas redes são

${ }^{23}$ Dados disponibilizados no site da Empresa C. 
em geral enterradas, pelas próprias características de seus negócios - optou-se por restringir o escopo do estudo de caso da Empresa $\mathrm{C}$ exclusivamente às suas redes enterradas.

Diferentemente do procedimento adotado nas Empresas A e B, a coleta de dados sobre os processos de construção e de manutenção da Empresa $C$ foi feita entrevistando-se a mesma pessoa, que neste caso foi o engenheiro responsável pela manutenção das redes enterradas da empresa. $O$ motivo é que a equipe sob sua responsabilidade, composta por funcionários próprios, tem atuação multifuncional: ela é diretamente responsável pela manutenção corretiva e preventiva, mas, em épocas de baixa demanda, também contribui na construção de redes, embora a maior parte da construção em si seja executada por empresas contratadas. Para garantir a separação dos dados entre os dois processos, a entrevista foi dividida em duas partes, descritas nas Seções 5.3.1 e 5.3.2.

\subsubsection{Processo de construção de redes de distribuição de energia elétrica}

A primeira parte da entrevista tratou do processo de construção. O engenheiro explicou que, quando atua na construção, o escopo de seu trabalho abrange a obtenção dos recursos necessários (materiais, equipamentos, mão-de-obra) e a execução da obra. Assim, seus principais fornecedores são o Almoxarifado Central, que fornece os materiais, e a Área Corporativa, que disponibiliza o projeto e a verba necessária. Já os clientes são os próprios consumidores da empresa que passam a ser supridos pela energia elétrica (Quadro 5-9).

Quadro 5-9 - Processo de construção de redes de energia elétrica pela Empresa C

\begin{tabular}{lll}
\hline Fornecedores (e o que fornecem): & Processos atribuídos: & Clientes (e o que recebem): \\
\hline Internos: & - Projeto de rede & Externos: \\
- Almoxarifado Central (materiais) & - Reserva de materiais & - Consumidor (energia \\
- Área Corporativa (projeto e & - Construção de rede & elétrica) \\
$\quad$ verba) & - Ligação de & \\
& consumidores & \\
\hline
\end{tabular}

Os dados coletados são apresentados a seguir, juntamente com o Grau de Aplicação (GA) e o Grau de Relação (GR) de cada prática considerada:

\section{Padronização e estabilidade}

- Procedimentos habilitadores: A empresa possui procedimentos claros de trabalho para suas atividades. Os procedimentos, porém, são elaborados de 
forma corporativa, sem a participação dos funcionários que lidam diretamente com cada atividade ( $G A=1)$. O principal aspecto abordado nos procedimentos, segundo o entrevistado, continua sendo o cuidado com a segurança, não havendo maior preocupação quanto à produtividade. No entanto, alguns grupos de trabalho já começaram a contemplar este tema na revisão dos procedimentos de trabalho, buscando maneiras mais rápidas e mais baratas de executar as atividades (GR=1 - C/LT).

- Sistema 5S: Não foi observada a implantação de um Sistema 5S ou similar no processo de construção da Empresa $\mathrm{C}$. $\mathrm{O}$ entrevistado mencionou que algumas outras áreas da empresa já têm algo implantado nesse sentido, mas desconhece sua aplicação em processos de construção $(\mathrm{GA}=0)$. 0 entrevistado acredita que, devido ao sucesso desta prática nas áreas em que foi implantada, ela deverá ser logo adotada corporativamente, o que irá contribuir para a diminuição de desperdícios em todos os aspectos (GR=2 Q/C/LT).

- Heijunka: A prática do Heijunka pôde ser observada na busca pelo nivelamento em volume de trabalho por meio da multifuncionalidade da equipe sob responsabilidade do entrevistado. O sistema funciona da seguinte maneira: durante as épocas de chuvas, em que o risco de falhas é maior, a equipe atua quase que exclusivamente na manutenção corretiva e preventiva das redes; em contrapartida, em períodos de seca, em que a demanda por manutenções diminui, a mesma equipe atua na construção de redes novas. Esta busca pelo nivelamento, no entanto, depende exclusivamente da iniciativa do gestor de cada equipe, não sendo aplicada na empresa como um todo, e não leva em conta o mix de atividades executadas $(\mathbf{G A}=\mathbf{1})$. Nos locais em que ela é aplicada, resultados significativos em termos de melhoria da produtividade e eliminação do desperdício de espera (ociosidade) já foram alcançados. Espera-se que no futuro esta prática seja aplicada também nas demais áreas, mas ainda sem considerar a questão do mix (GR=1 - C). 


\section{Just-In-Time}

- Fluxo Contínuo / Takt time: O entrevistado informou que não conhece casos de aplicação de conceitos de fluxo contínuo e de takt time em processos de construção áreas de construção da empresa $(G A=0)$, e que também existe grane dificuldade para se implantar o fluxo contínuo, devido ao fato de cada trabalho ser cada trabalho ser executado em um local diferente, e de uma forma diferente (GR=0).

- Sistema puxado: O entrevistado informou que até já se cogitou implantar um sistema puxado na área de construção de redes da empresa, com foco na aquisição de materiais. A iniciativa, no entanto, teve de enfrentar dois problemas: primeiro, o lead time dos fornecedores de materiais, geralmente muito longo (cerca de três meses) e incerto (alta taxa de atrasos); segundo, a burocracia interna para efetuação da compra, dificultada por regras rígidas de governança corporativa, que não oferece a agilidade requerida. Assim, esta iniciativa não avançou no processo de construção da empresa, e ainda não evidências de aplicação de sistema puxado $(G A=0)$. Também não se espera que algo similar seja implantado em curto prazo (GR=0).

- Setup Rápido: No processo de construção da Empresa C, não é conhecido nenhum tipo de iniciativa que se assemelhe à aplicação do Setup Rápido $(G A=0)$. O entrevistado também não acredita que o intervalo de tempo para desmobilização, transporte e mobilização, na mudança da equipe de construção de um local ao seguinte, seja tão significativo no processo de construção a ponto de justificar a adoção de alguma forma de Setup Rápido ( $G R=0$ ).

\section{Jidoka}

- Autonomação: O entrevistado não conhece nenhum exemplo de dispositivo que, no processo de construção, seja capaz de evitar a propagação de problemas $(G A=0)$, e também não foi capaz de levantar o que poderia ser implantado nesse sentido ( $G R=0$ ). 
- Poka-yoke: O entrevistado citou como exemplo de poka-yoke no processo de construção um equipamento recentemente adotado pela empresa: o Identificador de Cabos $\mathrm{Cl}$, do fornecedor SebaKMT ${ }^{24}$, constituído de um gerador de pulso de corrente e um receptor. O gerador envia pulsos em ondas ao cabo, permitindo que o receptor o identifique em outro local por meio do campo eletromagnético gerado (Figura 5-7). Assim, após a construção de uma nova rede em um local onde já existam outros cabos de energia, o técnico de campo pode ter a certeza de estar efetuando a conexão no cabo correto. Trata-se de uma solução poka-yoke, mas aplicada de forma pontual e baseada em tecnologias já existentes no mercado, não sendo, portanto, resultado do desenvolvimento de soluções para prevenção de falhas pela empresa $(G A=1)$. A principal motivação para a adoção deste equipamento é garantir a segurança do trabalhador no momento da conexão, e não eliminar desperdícios (GR=0).

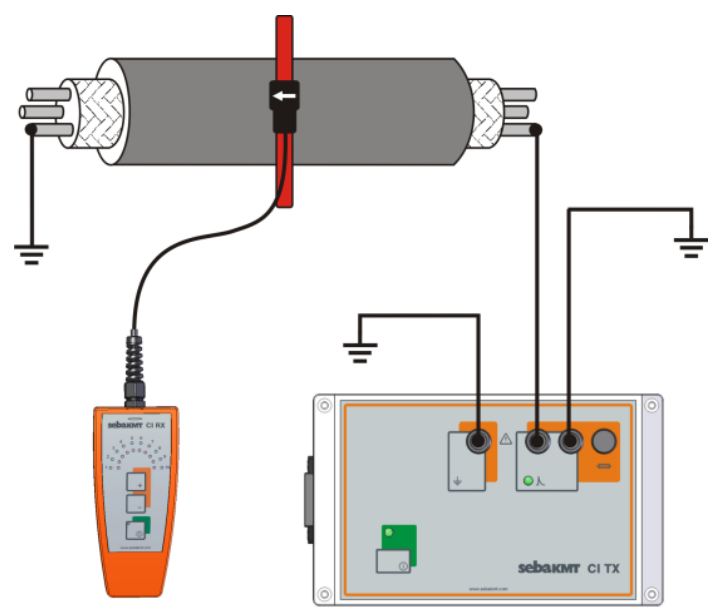

Figura 5-7-Uso do Identificador de Cabos Cl (material disponibilizado pela Empresa C)

${ }^{24}$ Mais detalhes sobre o equipamento no site www.sebakmt.com, acessado em 05/05/2009. 


\section{Envolvimento}

- Solução de Problemas. O entrevistado explicou que a Empresa C vem implantando de forma corporativa, há alguns anos, um Programa de Excelência no Desempenho, definido em sua apresentação oficial como "(...) um conjunto estruturado de metodologias e ferramentas da Qualidade, que podem ser usadas para aperfeiçoar processos, assim como identificar soluções para diversos tipos de problemas, por meio de projetos" (Figura 5-8). Entre as ferramentas incluídas, está o Cinco Por Quês, tal qual descrito na Seção 3.2.4. Segundo o entrevistado, embora o programa tenha proporcionado resultados concretos, ainda não está difundido em todos os níveis da empresa $(G A=1)$. A tendência, no entanto, é que sua aplicação se dissemine, já que está previsto o desdobramento de um treinamento corporativo nesse sentido em um futuro próximo (GR=2 - Q/C/LT).

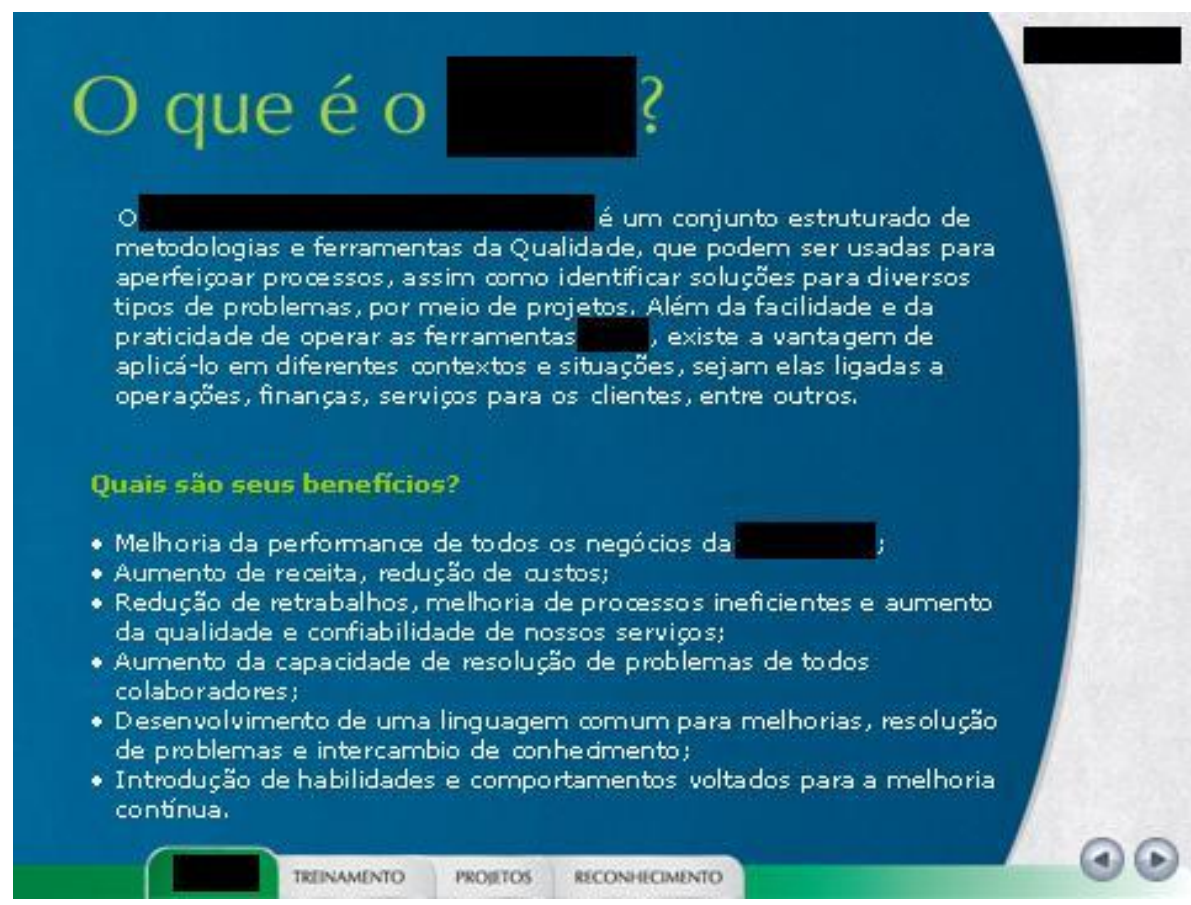

Figura 5-8 - Slide da apresentação sobre o Programa de Excelência no Desempenho da Empresa C (material fornecido pela empresa; nomes omitidos para preservar sua identidade).

- Grupos kaizen: Grupos de melhoria têm sido formados na empresa, tanto por meio de seu Programa de Excelência no Desempenho quanto por iniciativa dos próprios empregados, mas estes são poucos e com atuação pontual. Outro problema, segundo o entrevistado, é a falta de produtividade dos grupos, que ele atribui ao número excessivo de participantes em cada grupo (de vinte a trinta) e à "vaidade" das áreas envolvidas (GA=1). Para o 
futuro, espera-se uma maior difusão desta prática, devido à própria extensão do Programa mencionado acima e à tendência de evolução na aprendizagem que o mesmo proporciona (GR=2 - Q/C/LT).

- Programa de sugestão: Não há na Empresa C, pelo menos de forma estruturada, um programa de sugestão implantado $(G A=0)$. Porém, o entrevistado acredita tratar-se de uma prática de fácil implantação, desde que com apoio da liderança, e que poderá trazer ganhos em termos de melhoria de processos e eliminação de desperdícios (GR=2 - Q/C/LT).

\section{TPEM}

- TPM-AM (manutenção autônoma): As equipes de construção não realizam nenhum tipo de manutenção nos equipamentos utilizados nas obras (tais como guinchos, retroescavadeiras e guindautos). Caso encontrem algum equipamento avariado, a ordem é efetuar a troca $(\mathbf{G A}=0)$. Também não há estímulo para que essa situação se altere em um futuro próximo (GR=0).

- TPM-PM (manutenção preventiva e preditiva): $\mathrm{Na}$ Empresa $\mathrm{C}$, os equipamentos utilizados no processo de construção de redes elétricas não sofrem manutenção preventiva ou preditiva, só sendo enviados para conserto quando ocorre a quebra $(G A=0)$. $O$ entrevistado acredita que um plano de manutenção preventiva melhoraria a confiabilidade dos equipamentos e ajudaria a evitar atrasos no cronograma. Contudo, tal prática seria de difícil implantação, já que boa parte dos equipamentos utilizados é terceirizada (GR=1 - LT).

- TPM-EM (gerenciamento do equipamento): Os equipamentos de construção são buscados no mercado, mas não é feita propriamente uma busca pelos equipamentos que necessitam de menos cuidados com manutenção $(G A=0)$. A inclusão deste critério na escolha dos equipamentos a serem usados numa obra representaria um avanço em termos de custo, mas seria de difícil implantação, por envolver várias áreas da empresa (GR=1 - C).

\section{SBCE}

- SBCE: A equipe do entrevistado já desenvolveu uma experiência de projeto que foi elaborado em conjunto pelas áreas de Engenharia, Construção e 
Manutenção, e o resultado foi satisfatório, mas sem o desenvolvimento de um conjunto de soluções, como prevê o SBCE $(G A=1)$. O entrevistado afirma que o maior ganho foi a diminuição do retrabalho e perda de tempo nos processos de construção e manutenção, o que revela um alto grau de relação com as motivações do pensamento enxuto (GR=2 - LT).

\section{Last Planner}

- Kit Completo: No processo de construção, a Empresa C dispõe de um sistema de informação que garante que todos os materiais, mão-de-obra e equipamentos estejam disponíveis no local antes do início da execução. As atividades também não são executadas se a equipe está sem o projeto (informação), sem condições externas favoráveis, ou com atividades precedentes ainda pendentes. Porém, persiste a questão da liberação do espaço: a equipe necessita de autorização dos órgãos competentes para executar obras em vias públicas (ver Seção 2.4.1), mas a mesma nem sempre é obtida adequadamente, provocando embargos de obra e conseqüentes atrasos $(G A=1)$. $O$ entrevistado acredita que uma melhor gestão do relacionamento com os órgãos competentes e uma melhoria no sistema de informação de controle de obras - que ainda não prevê o controle de autorizações - resolveria este problema (GR=2 - LT).

- Medição e monitoramento do PPC: Existe o monitoramento da porcentagem executada do plano de construção, mas com base no plano macro, sem a análise da causa de atrasos $(\mathrm{GA}=0$ ). $\mathrm{O}$ entrevistado vê alguma possibilidade de melhoria no controle da execução de construções, com um maior detalhamento dos dados para aprimoramento do controle. Porém, ele acredita que estabelecer o monitoramento pelo planejamento diário implicaria na necessidade de quebrar um paradigma forte (GR=1 - LT).

- Reserva de Tarefas: A diretoria regional da Empresa C mantém um estoque de material e recursos para os próximos 20 dias de obra, o que caracteriza a previsão de uma Reserva de Tarefas ( $G A=2)$. Porém, há um exagero na estocagem de materiais, já que além destes 20 dias ainda existe um estoque no Almoxarifado Central da empresa. Segundo o entrevistado, o que 
prejudica a diminuição deste estoque é a imprevisibilidade da entrega por parte do fornecedor, problema de difícil solução (GR=1 - LT).

- Lookahead: Pela política vigente na Empresa C, a responsabilidade pela verificação dos recursos de construção com a antecedência necessária (principalmente dos materiais) cabe sempre ao gestor do projeto. Contudo, o gestor muitas vezes não consegue conciliar essa verificação com a gestão da obra em si, e acaba deixando a primeira em segundo plano, causando falta de recursos e conseqüentes atrasos $(G A=1)$. $O$ entrevistado informou que este problema já está sendo resolvido por meio da contratação de um gestor de materiais e recursos para as obras, o que evidencia a preocupação da administração com o desperdício existente (GR=2 - LT).

A tabulação dos dados considerados e avaliados nesta seção encontra-se no Quadro 5-10. 
Quadro 5-10 - Tabulação dos dados - Empresa C - Processo de construção

\begin{tabular}{|c|c|c|c|c|}
\hline Prática & & Nome & GA & GR \\
\hline \multicolumn{5}{|c|}{ Padronização e Estabilidade } \\
\hline 1 & \multicolumn{2}{|l|}{ Procedimentos habilitadores } & 1 & $1-\mathrm{C} / \mathrm{LT}$ \\
\hline 2 & \multicolumn{2}{|l|}{ Sistema 5S } & 0 & $2-Q / C / L T$ \\
\hline 3 & \multicolumn{2}{|l|}{ Heijunka } & 1 & $1-\mathrm{C}$ \\
\hline \multicolumn{5}{|c|}{ Just-In-Time } \\
\hline 4 & \multicolumn{2}{|l|}{ Fluxo Contínuo / Takt time } & 0 & 0 \\
\hline 5 & \multicolumn{2}{|l|}{ Sistema puxado } & 0 & 0 \\
\hline 6 & \multicolumn{2}{|l|}{ Setup Rápido } & 0 & 0 \\
\hline \multicolumn{5}{|l|}{ Jidoka } \\
\hline 7 & \multicolumn{2}{|l|}{ Autonomação } & 0 & 0 \\
\hline 8 & \multicolumn{2}{|l|}{ Poka-yoke } & 1 & 0 \\
\hline \multicolumn{5}{|c|}{ Envolvimento } \\
\hline 9 & \multicolumn{2}{|l|}{ Solução de Problemas } & 1 & $2-Q / C / L T$ \\
\hline 10 & \multicolumn{2}{|l|}{ Grupos kaizen } & 1 & $2-Q / C / L T$ \\
\hline 11 & \multicolumn{2}{|l|}{ Programa de Sugestão } & 0 & $2-\mathrm{Q} / \mathrm{C} / \mathrm{LT}$ \\
\hline \multicolumn{5}{|l|}{ TPEM } \\
\hline 12 & \multicolumn{2}{|c|}{ TPM-AM (Manutenção Autônoma) } & 0 & 0 \\
\hline 13 & \multicolumn{2}{|c|}{ TPM-PM (Manutenção Preventiva e Preditiva) } & 0 & $1-\mathrm{LT}$ \\
\hline 14 & \multicolumn{2}{|c|}{ TPM-EM (Gerenciamento de Equipamentos) } & 0 & $1-\mathrm{C}$ \\
\hline \multicolumn{5}{|c|}{ 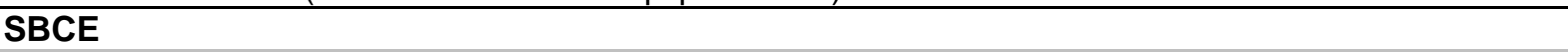 } \\
\hline 15 & \multicolumn{2}{|l|}{ SBCE } & 1 & $2-\mathrm{LT}$ \\
\hline \multicolumn{5}{|c|}{ Last Planner } \\
\hline 16 & \multicolumn{2}{|l|}{ Kit Completo } & 1 & $2-L T$ \\
\hline 17 & \multicolumn{2}{|c|}{ Medição e monitoramento do PPC } & 0 & $1-\mathrm{LT}$ \\
\hline 18 & \multicolumn{2}{|l|}{ Reserva de Tarefas } & 2 & $1-\mathrm{LT}$ \\
\hline 19 & \multicolumn{2}{|l|}{ Lookahead } & 1 & $2-L T$ \\
\hline \multicolumn{2}{|c|}{$\begin{array}{l}\text { Grau de Aplicação (GA): } \\
\text { 0: Nenhuma evidência de aplicação } \\
\text { 1: Aplicação parcial } \\
\text { 2: Aplicação efetiva }\end{array}$} & \multicolumn{3}{|c|}{$\begin{array}{l}\text { Grau de Relação (GR): } \\
\text { 0: Nenhuma relação com a eliminação do desperdício; } \\
\text { 1: Alguma relação com a eliminação do desperdício; } \\
\text { 2: Forte relação com a eliminação do desperdício; } \\
\text { Q; Percebido o objetivo de melhorar Qualidade; } \\
\text { C: Percebido o objetivo de diminuir Custo; } \\
\text { LT: Percebido o objetivo de diminuir Lead Time. }\end{array}$} \\
\hline
\end{tabular}

\subsubsection{Processo de manutenção de redes de distribuição de energia elétrica}

A segunda parte da entrevista tratou do processo de manutenção. O engenheiro explicou que para realizar manutenção preventiva de redes existentes, seu escopo de trabalho também se mantém na obtenção dos recursos necessários tais como materiais, equipamentos, mão-de-obra e na execução dos trabalhos de manutenção em si. Assim, seus principais fornecedores são o Almoxarifado Central que fornece os materiais e a Área Corporativa que disponibiliza os planos de manutenção para execução. Já os clientes são os próprios consumidores da empresa que têm a rede elétrica mantida operante (Quadro 5-11). 
Quadro 5-11 - Processo de manutenção de redes de energia elétrica pela Empresa C

\begin{tabular}{lll}
\hline Fornecedores (e o que fornecem): & Processos atribuídos: & Clientes (e o que recebem): \\
\hline Internos: & - Reserva de materiais & Externos: \\
$\begin{array}{l}\text { - Almoxarifado Central (materiais) } \\
\text { - Área Corporativa (planos de }\end{array}$ & $\begin{array}{l}\text { Manutenção de rede } \\
\text { manutenção) }\end{array}$ & $\begin{array}{l}\text { (preventiva e } \\
\text { corretiva) }\end{array}$ \\
\hline
\end{tabular}

Os dados sobre a aplicabilidade das práticas enxutas no contexto do processo de manutenção e as avaliações do seu Grau de Aplicação (GA) e Grau de Relação (GR) são apresentados a seguir:

\section{Padronização e estabilidade}

- Procedimentos habilitadores: De forma semelhante ao que ocorre no processo de construção da Empresa C, existem procedimentos claros de trabalho para suas atividades de manutenção, mas estabelecidos de forma corporativa e sem a participação dos funcionários que lidam diretamente com sua execução em campo $(G A=1)$. A preocupação central dos procedimentos está voltada à segurança, sendo pouca atenção dedicada à questão da produtividade. Recentemente, este ponto passou a ser enfatizado (GR=1 - C/LT).

- Sistema 5S: O entrevistado afirma conhecer iniciativas de aplicação do Sistema 5S em outras áreas de manutenção da empresa. Essas iniciativas, no entanto, não são corporativas e dependem da visão e atuação do diretor de cada unidade $(G A=1)$. Contudo, ele acredita que esta prática possa ser disseminada para as demais áreas de manutenção da empresa, com ganhos em todos os sentidos (GR=2 - Q/C/LT).

- Heijunka: Apoiada na sua multifuncionalidade, as mesmas equipes alocadas em trabalhos de manutenção preventiva e corretiva, nos momentos de baixa demanda desta, também atuam no processo de construção, caracterizando a preocupação da gerência com o nivelamento em volume de trabalho. Deve ser considerado, no entanto, o fato deste nivelamento depender exclusivamente da iniciativa do gestor desta equipe e de, mesmo nos casos em que é aplicado, não levar em conta o mix de atividades da manutenção ou da construção ( $G A=1$ ). A aplicação desta prática na forma em que tem sido aplicada com a equipe do entrevistado deve se disseminar na empresa, 
mas ainda sem levar em conta a questão do nivelamento em mix dos diferentes tipos de trabalho $(\mathbf{G R}=\mathbf{1}-\mathbf{C})$.

\section{Just-In-Time}

- Fluxo Contínuo / Takt time: De forma semelhante ao processo de construção, o entrevistado informou que não conhece casos de aplicação de práticas de fluxo contínuo e de Takt time em áreas de manutenção de redes enterradas da Empresa C, sendo a mesma considerada aplicável somente na área de Manutenção de Equipamentos, cujo processo de trabalho se assemelha ao de uma fábrica ${ }^{25}(\mathrm{GA}=\mathbf{0})$. Mesmo que sejam caracterizadas por uma complexidade menor que a dos processos de construção, as atividades do processo de manutenção ainda têm o problema de serem executadas em diversos locais diferentes, dificultando o estabelecimento da prática de fluxo contínuo (GR=0).

- Sistema puxado: O entrevistado informou que no processo de manutenção conseguiu obter melhores resultados do que no processo de construção no desenvolvimento de um sistema puxado para controle dos estoques de materiais, embora também enfrente problemas com o lead time dos fornecedores de materiais e com a burocracia interna para efetuação da compra $(G A=1)$. Assim, pelo menos no processo de manutenção, espera-se que esta prática possa ser mais disseminada, ainda que com certa dificuldade (GR=1 - C).

- Setup Rápido: No processo de manutenção da Empresa C, existe uma clara preocupação com redução do tempo de setup. As equipes em campo informam continuamente o status de seus trabalhos à Sala de Controle, e as ordens de manutenção são emitidas por esta sempre para as equipes livres que estiverem mais próximas do local, identificadas por um sistema de monitoramento com tecnologia de Global Positioning System (GPS) ${ }^{26}$. Assim, perde-se menos tempo com os deslocamentos, que fazem parte do

25 Segundo o entrevistado, as áreas em questão operam como oficinas que recebem os equipamentos das equipes de campo e executam atividades padronizadas de manutenção, despachando os equipamentos novamente para o campo após executado o serviço. Por suas atividades não serem executadas em campo, elas não fazem parte do escopo desta dissertação.

${ }^{26}$ Sistema de Posicionamento Global. 
Setup neste tipo de atividade. No entanto, falta maior interesse no sentido de racionalizar outras atividades de setup, como a desmobilização da equipe logo após a conclusão de um trabalho e a sua mobilização no trabalho seguinte $(G A=1)$. $O$ entrevistado acredita que uma análise mais minuciosa dos tempos consumidos nessas atividades não apenas tornaria o setup em si mais rápido, como também contribuiria para reduzir o lead time das atividades do processo de manutenção ( $G R=2-\mathbf{L T}$ ).

\section{Jidoka}

- Autonomação: Como exemplo de dispositivo que atua no caso de falha prevenindo a propagação de seu efeito, o entrevistado citou o Network Protector, presente nas câmaras transformadoras da empresa (Figura 5-9). Quando a diferença de voltagem e ângulo de fase estão conformes às especificações da corrente a ser fornecida (situação normal), este dispositivo fecha o circuito e permite a passagem de corrente. Contudo, se as características indicarem que a energia terá caminho contrário (situação de curto circuito), ele abre o circuito e impede a passagem, preservando a rede. Trata-se de um dispositivo de autonomação já adotado por distribuidoras de energia elétrica em todo o mundo e previsto em norma, não sendo resultado de desenvolvimento da própria empresa (GA=1). A principal preocupação da adoção de dispositivos desta natureza é a segurança e o cumprimento de normas, e não a melhoria da produtividade do processo em si (GR=0).

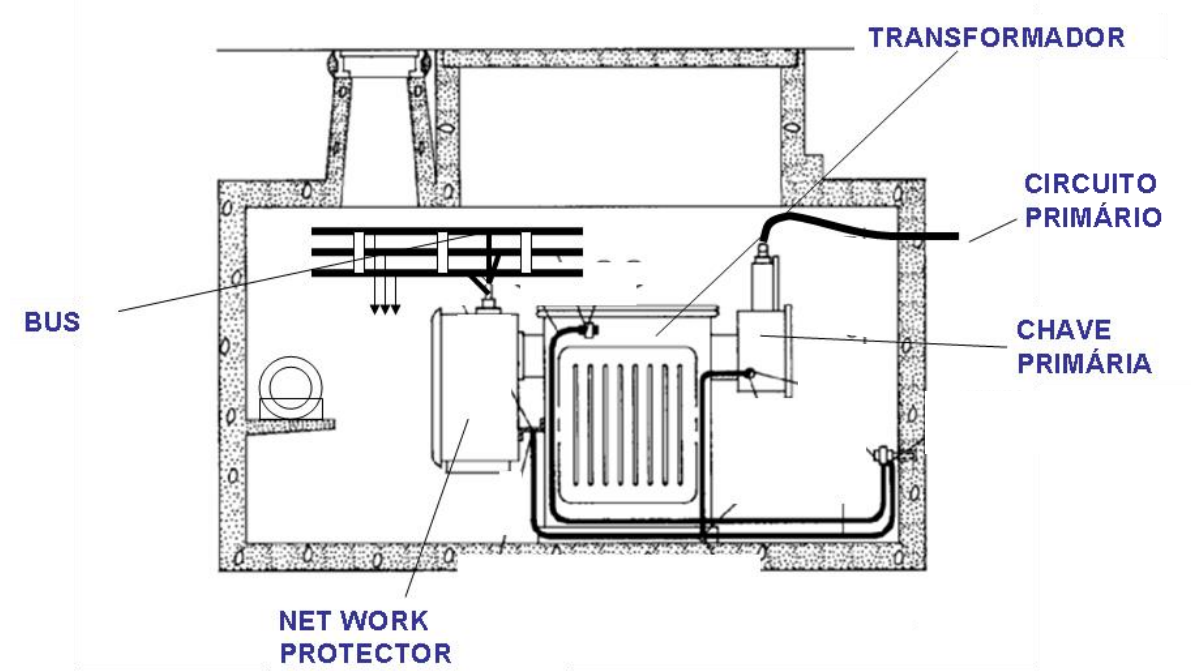

Figura 5-9- Câmara transformadora da rede de distribuição subterrânea de energia elétrica (adaptada de material fornecido pela Empresa C). 
- Poka-yoke: Uma importante prática de poka-yoke é utilizada por técnicos de campo na religação da rede após uma manutenção, para evitar que se faça uma inversão de fase neste procedimento. Sempre que um técnico fornece corrente a uma das fases de uma rede, avisa um outro disposto no final da mesma rede e este, para se certificar que manuseia o cabo correto e evitar curto-circuito, conecta uma lâmpada e verifica se a mesma se acende. Tratase de uma solução simples e eficaz de poka-yoke, mas ainda é incomum a aplicação de práticas como esta no processo de manutenção (GA=1). $O$ entrevistado não percebe na empresa um maior interesse para promover 0 desenvolvimento e difusão deste tipo de prática (GR=0).

\section{Envolvimento}

Para as três práticas relacionadas com Envolvimento o Grau de Aplicação e o Grau de Relação podem ser admitidos iguais para toda a Empresa $C$, já que as práticas desta natureza, conforme explica o entrevistado, têm sido implantadas de forma corporativa. Assim, o processo de manutenção compartilha as mesmas avaliações atribuídas a estes graus no processo de construção apresentados na Seção 5.3.1, conforme segue:

- Solução de Problemas: GA=1; GR=2 - Q/C/LT.

- Grupos kaizen: $\mathbf{G A = 1 ; ~ G R = 2 ~ - ~ Q / C / L T . ~}$

- Programa de sugestão: GA=0; GR=2 - Q/C/LT.

\section{TPEM}

- TPM-AM (manutenção autônoma): No processo de manutenção da Empresa $\mathrm{C}$, não existe propriamente um operador de produção que poderia receber maior autonomia para também fazer tarefas de manutenção, uma vez que a rede trabalha sozinha e qualquer tipo de trabalho é considerado manutenção $(\mathrm{GA}=0)$. Por não ser aplicável no âmbito do processo de manutenção, não se vê motivo para tentar implantar algo nesse sentido (GR=0).

- TPM-PM (manutenção preventiva e preditiva): Já está em andamento um projeto de implantação de Reliability Centered Maintenance ${ }^{27}$ (RCM), que

\footnotetext{
${ }^{27}$ Manutenção Centrada em Confiabilidade.
} 
tem princípios similares ao TPM-PM, em algumas áreas da empresa. Este projeto já foi implantado com algum sucesso, por exemplo, na manutenção de subestações, mas ainda não avançou na área de redes subterrâneas, onde a entrevista foi desenvolvida. Segundo o entrevistado, isso se deve à falta de tempo de sua equipe para poder se dedicar à implantação $(G A=1)$. O entrevistado pode vir a implantá-la no futuro e acredita que tem muito a ganhar com sua aplicação, principalmente porque possibilitará que a equipe de manutenção atue somente naquilo que é necessário, não gastando tempo e dinheiro à toa $(\mathbf{G R = 2}-\mathbf{C} / \mathbf{L T})$.

- TPM-EM (gerenciamento do equipamento): O entrevistado disse que a empresa tenta utilizar, quando possível, equipamentos que necessitem de menos manutenção, mas não soube exemplificar nenhum caso em que este quesito realmente tenha influenciado na decisão de escolha de um equipamento $(\mathbf{G A}=0)$. Ele acredita que o TPM-EM possa ser implantado no futuro, embora implique na necessidade de se quebrar muitos paradigmas $(G R=1-C)$.

\section{SBCE}

- SBCE: A equipe de manutenção do entrevistado participou do mesmo projeto citado na Seção 5.3.1, que foi desenvolvido em conjunto com as áreas de Engenharia, Construção e Manutenção. A falta de tempo, no entanto, é mais uma vez citada como dificuldade para a aplicação do conceito de SBCE de forma mais sistemática no desenvolvimento de projetos em geral $(G A=1)$. No caso em que foi possível conciliar um trabalho conjunto, o ganho com a diminuição do retrabalho foi considerado relevante (GR=2 - LT).

\section{Last Planner}

- Kit Completo: O entrevistado lamenta que a equipe de manutenção ainda não disponha de um sistema de informação como o utilizado pela equipe de construção para controlar todos os recursos requeridos para a execução de uma atividade. Assim, a correria de última hora para garantir os recursos necessários ocorre com freqüência $(G A=0)$. Para o futuro, existe um projeto de adaptação do sistema de informação utilizado no processo de construção 
para implantação no processo de manutenção, o que deve melhorar este processo e diminuir os problemas com indisponibilidade de recursos ( $G R=2$ - LT).

- Medição e monitoramento do PPC: Existe o monitoramento da porcentagem executada do plano de manutenção preventiva, mas isso também é realizado apenas com base no plano macro, sem a análise dos atrasos $(G A=0)$. O entrevistado prevê que se possa desenvolver alguma melhoria nesse sentido, mas considera que o fato de uma mesma equipe atuar na manutenção corretiva e na manutenção preventiva dificulta o planejamento e a análise dos atrasos do plano (GR=1 - LT).

- Reserva de Tarefas: A existência de uma reserva de tarefas de manutenção preventiva já é algo inerente ao processo, uma vez que sempre se pode adiantar alguma atividade programada para a semana seguinte se algum imprevisto impede de se executar aquilo que estava programado para a semana em questão $(\mathbf{G A}=0)$. Pelo mesmo motivo, não há iniciativa por parte da empresa de implantar tal prática neste processo (GR=0).

- Lookahead: A responsabilidade pela verificação dos recursos necessários para execução de um trabalho de manutenção (materiais, equipamentos, etc.) é do próprio gestor da equipe, antes da execução da atividade. $\mathrm{O}$ mesmo problema constatado no processo de construção ocorre com esta prática na manutenção: o gestor muitas vezes não consegue conciliar essa verificação com a gestão das atividades do processo de manutenção em si, e acaba deixando a primeira em segundo plano, causando falta de recursos e conseqüentes atrasos $(\mathbf{G A}=\mathbf{1})$. $O$ entrevistado informou que este problema já está sendo resolvido por meio da contratação de um profissional responsável por gerir a disponibilização dos recursos para as atividades de campo (GR=2 - LT).

A tabulação dos dados levantados e avaliados nesta seção encontra-se no Quadro 5-12. 
Quadro 5-12 - Tabulação dos dados - Empresa C - Processo de manutenção

\begin{tabular}{|c|c|c|c|c|}
\hline \multirow{2}{*}{$\begin{array}{l}\text { Prática } \\
\text { Padron }\end{array}$} & \multicolumn{2}{|r|}{ Nome } & \multirow[t]{2}{*}{ GA } & \multirow[t]{2}{*}{ GR } \\
\hline & zação e Estabilidade & & & \\
\hline 1 & \multicolumn{2}{|l|}{ Procedimentos habilitadores } & 1 & $1-\mathrm{C} / \mathrm{LT}$ \\
\hline 2 & \multicolumn{2}{|l|}{ Sistema 5S } & 1 & $2-Q / C / L T$ \\
\hline 3 & \multicolumn{2}{|l|}{ Heijunka } & 1 & $1-\mathrm{C}$ \\
\hline \multicolumn{5}{|c|}{ Just-In-Time } \\
\hline 4 & \multicolumn{2}{|l|}{ Fluxo Contínuo / Takt time } & 0 & 0 \\
\hline 5 & \multicolumn{2}{|l|}{ Sistema puxado } & 1 & $1-C$ \\
\hline 6 & \multicolumn{2}{|l|}{ Setup Rápido } & 1 & $2-\mathrm{LT}$ \\
\hline \multicolumn{5}{|l|}{ Jidoka } \\
\hline 7 & \multicolumn{2}{|l|}{ Autonomação } & 1 & 0 \\
\hline 8 & \multicolumn{2}{|l|}{ Poka-yoke } & 1 & 0 \\
\hline \multicolumn{5}{|c|}{ Envolvimento } \\
\hline 9 & \multicolumn{2}{|l|}{ Solução de Problemas } & 1 & $2-Q / C / L T$ \\
\hline 10 & \multicolumn{2}{|l|}{ Grupos kaizen } & 1 & $2-Q / C / L T$ \\
\hline 11 & \multicolumn{2}{|l|}{ Programa de Sugestão } & 0 & $2-\mathrm{Q} / \mathrm{C} / \mathrm{LT}$ \\
\hline \multicolumn{5}{|l|}{ TPEM } \\
\hline 12 & \multicolumn{2}{|c|}{ TPM-AM (Manutenção Autônoma) } & 0 & 0 \\
\hline 13 & \multicolumn{2}{|c|}{ TPM-PM (Manutenção Preventiva e Preditiva) } & 1 & $2-\mathrm{C} / \mathrm{LT}$ \\
\hline 14 & \multicolumn{2}{|c|}{ TPM-EM (Gerenciamento de Equipamentos) } & 0 & $1-C$ \\
\hline \multicolumn{5}{|c|}{ 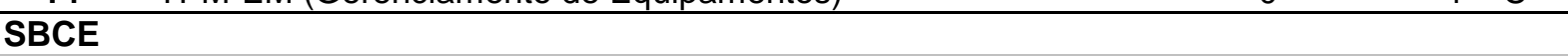 } \\
\hline 15 & \multicolumn{2}{|l|}{ SBCE } & 1 & $2-\mathrm{LT}$ \\
\hline \multicolumn{5}{|c|}{ Last Planner } \\
\hline 16 & \multicolumn{2}{|l|}{ Kit Completo } & 0 & $2-L T$ \\
\hline 17 & \multicolumn{2}{|c|}{ Medição e monitoramento do PPC } & 0 & $1-L T$ \\
\hline 18 & \multicolumn{2}{|l|}{ Reserva de Tarefas } & 0 & 0 \\
\hline 19 & \multicolumn{2}{|l|}{ Lookahead } & 1 & $2-L T$ \\
\hline \multicolumn{2}{|c|}{$\begin{array}{l}\text { Grau de Aplicação (GA): } \\
\text { 0: Nenhuma evidência de aplicação } \\
\text { 1: Aplicação parcial } \\
\text { 2: Aplicação efetiva }\end{array}$} & \multicolumn{3}{|c|}{$\begin{array}{l}\text { Grau de Relação (GR): } \\
\text { 0: Nenhuma relação com a eliminação do desperdício; } \\
\text { 1: Alguma relação com a eliminação do desperdício; } \\
\text { 2: Forte relação com a eliminação do desperdício; } \\
\text { Q; Percebido o objetivo de melhorar Qualidade; } \\
\text { C: Percebido o objetivo de diminuir Custo; } \\
\text { LT: Percebido o objetivo de diminuir Lead Time. }\end{array}$} \\
\hline
\end{tabular}




\section{Análise de dados}

Este capítulo é dedicado à análise e discussão dos casos apresentados no Capítulo 5, considerando as questões de pesquisa definidas na Seção 4.1 que direcionam o desenvolvimento do presente estudo.

\subsection{Grau de Aplicação de práticas enxutas em RDUs}

A primeira questão (Questão Q1), que é retomada abaixo, diz respeito ao grau de aplicação das práticas enxutas no contexto das RDU:

- Q1: Em que medida as empresas responsáveis por Redes de Distribuição de Utilidades (RDUs), aplicam cada uma das práticas de produção enxuta no processo de construção e no processo de manutenção?

Para elucidar a Questão Q1 em relação aos processos considerados, tomamse como base os Graus de Aplicação (GA) avaliados nos casos descritos no Capítulo 5.

Primeiramente, são analisados os dados para o processo de construção; na seqüência, repete-se a análise para o processo de manutenção, e, por fim, é apresentado um estudo comparativo entre os dois processos.

\subsubsection{Grau de Aplicação de práticas enxutas no processo de construção}

O Quadro 6-1 apresenta as práticas enxutas estudadas divididas conforme o Grau de Aplicação mensurado em cada uma das três empresas, tomando-se como base somente o processo de construção. 
Quadro 6-1 - Práticas enxutas conforme Grau de Aplicação no processo de construção

\begin{tabular}{|c|c|c|c|}
\hline & $\begin{array}{l}\text { Práticas sem nenhuma } \\
\text { evidência de aplicação } \\
(\mathrm{GA}=0) \text {. }\end{array}$ & $\begin{array}{l}\text { Práticas com aplicação parcial } \\
(G A=1)\end{array}$ & $\begin{array}{l}\text { Práticas com } \\
\text { aplicação efetiva } \\
\text { (GA=2) }\end{array}$ \\
\hline 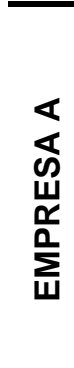 & $\begin{array}{l}\text { Heijunka } \\
\text { Fluxo Contínuo } \\
\text { Sistema puxado } \\
\text { Setup Rápido } \\
\text { TPM-AM } \\
\text { TPM-PM } \\
\text { TPM-EM } \\
\text { SBCE } \\
\text { Monitoramento PPC }\end{array}$ & $\begin{array}{l}\text { Procedimentos habilitadores } \\
\text { Autonomação } \\
\text { Poka-yoke } \\
\text { Solução de Problemas } \\
\text { Grupos kaizen } \\
\text { Kit Completo } \\
\text { Reserva de Tarefas } \\
\text { Lookahead }\end{array}$ & $\begin{array}{l}\text { Sistema 5S } \\
\text { Programa de Sugestão }\end{array}$ \\
\hline 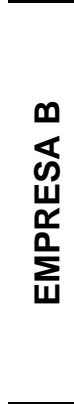 & $\begin{array}{l}\text { Fluxo Contínuo } \\
\text { Sistema puxado } \\
\text { Setup Rápido } \\
\text { Autonomação } \\
\text { Poka-yoke } \\
\text { TPM-AM } \\
\text { TPM-PM } \\
\text { TPM-EM } \\
\text { SBCE } \\
\text { Monitoramento PPC }\end{array}$ & $\begin{array}{l}\text { Procedimentos habilitadores } \\
\text { Sistema 5S } \\
\text { Heijunka } \\
\text { Solução de problemas } \\
\text { Grupos kaizen } \\
\text { Lookahead }\end{array}$ & $\begin{array}{l}\text { Programa de Sugestão } \\
\text { Kit Completo } \\
\text { Reserva de Tarefas }\end{array}$ \\
\hline 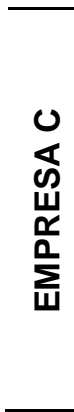 & $\begin{array}{l}\text { Sistema 5S } \\
\text { Fluxo Contínuo } \\
\text { Sistema puxado } \\
\text { Setup Rápido } \\
\text { Autonomação } \\
\text { Programa de Sugestão } \\
\text { TPM-AM } \\
\text { TPM-PM } \\
\text { TPM-EM } \\
\text { Monitoramento PPC }\end{array}$ & $\begin{array}{l}\text { Procedimentos habilitadores } \\
\text { Heijunka } \\
\text { Poka-yoke } \\
\text { Solução de problemas } \\
\text { Grupos kaizen } \\
\text { SBCE } \\
\text { Kit Completo } \\
\text { Lookahead }\end{array}$ & Reserva de Tarefas \\
\hline
\end{tabular}

Por meio do Quadro 6-1, percebe-se que os padrões de aplicação geral das práticas consideradas são semelhantes nas três empresas, embora o número de práticas com aplicação efetiva seja ligeiramente diferente.

A Empresa A apresenta aplicação de dez das dezenove práticas enxutas consideradas no processo de construção, dentre as quais se destaca a aplicação efetiva do Sistema $5 S$ e do Programa de Sugestão. Ambos foram implantados de forma corporativa, por meio de programas estruturados e têm continuidade provada, mantendo-se operantes já há alguns anos. O Sistema 5S foi desenvolvido englobando todas as áreas da empresa, e inclui inspeções feitas nos locais de obra que, além de outros itens, verificam a questão da organização. Já o Programa de Sugestão está estruturado e disponível a todos os profissionais, servindo como uma fonte de idéias que contribuíram para diversas melhorias em processos. 
Na Empresa B, foram identificadas nove práticas com algum grau de aplicação e três com aplicação efetiva. As práticas que merecem destaque são novamente o Programa de Sugestão, e ainda o Kit Completo e a Reserva de Tarefas. A Empresa $B$ também já possui um programa estruturado para o envio de sugestões, apoiado por um sistema implantado na intranet da empresa. Já o Kit Completo, neste caso, é garantido por meio da obrigatoriedade de preenchimento de um check-list no início da obra, enquanto a Reserva de Tarefas se sustenta na disponibilização de recursos para três meses de obra.

Na Empresa C, também existem nove práticas com grau de aplicação positivo. A única prática para a qual o grau de aplicação no processo de construção pode ser considerado efetivo é a Reserva de Tarefas: a empresa dispõe de um estoque de material e uma disponibilidade de recursos pelo menos para pelo menos 20 dias de obra.

O gráfico da Figura 6-1 apresenta as dezenove práticas em ordem decrescente $^{28}$ de Grau de Aplicação Geral (GAG), variável definida na Seção 4.4.3, no processo de construção. As hachuras em cada coluna distinguem o GA levantado em cada empresa no cômputo do GAG das práticas consideradas.

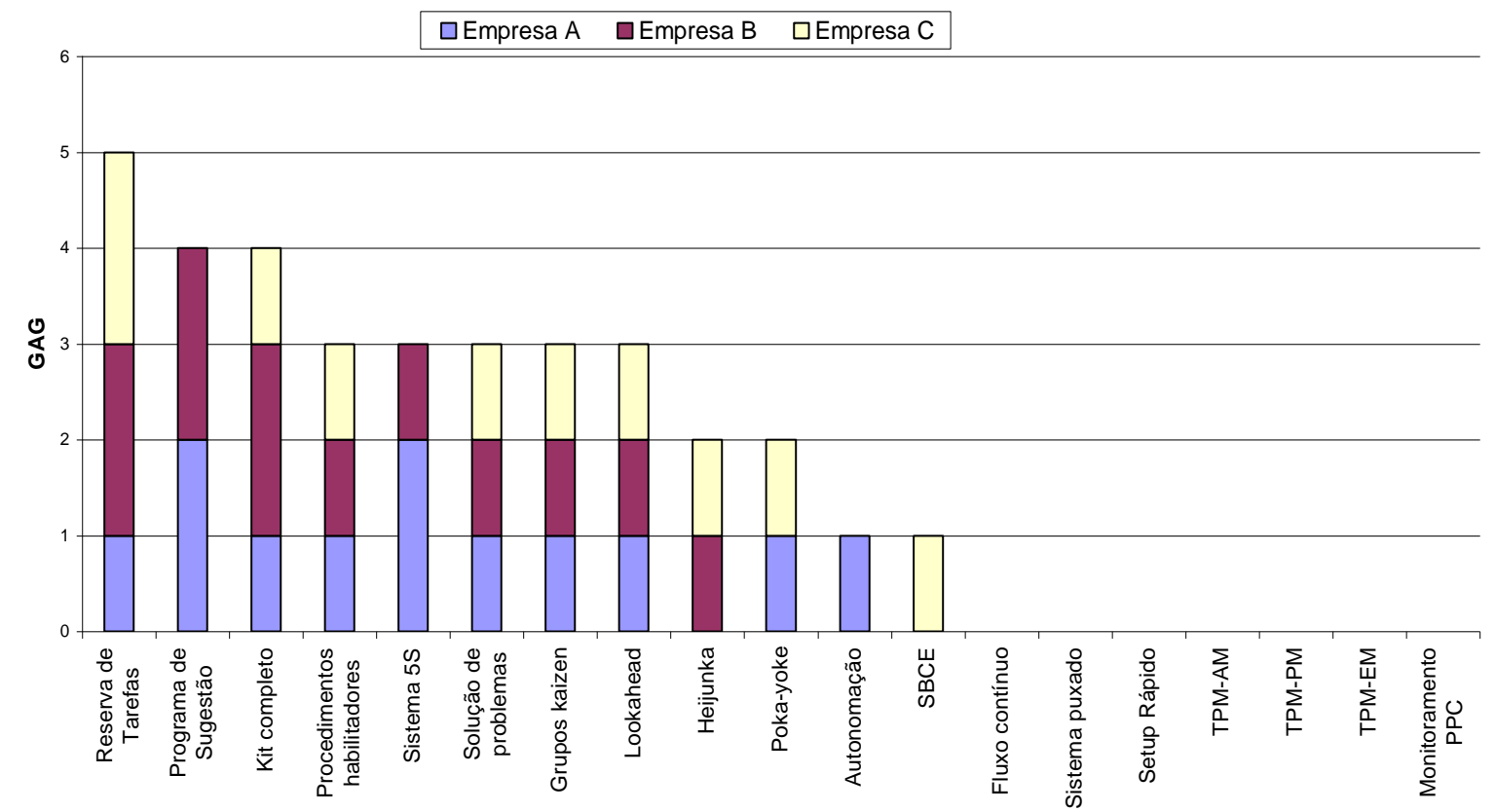

Figura 6-1 - Práticas enxutas conforme Grau de Aplicação Geral (GAG) no processo de construção

\footnotetext{
${ }^{28}$ Neste gráfico, assim como nos gráficos subseqüentes, não há critérios de desempate. Práticas que tenham GAG igual - ou GRG, quando for estudado o Grau de Relação - são apresentadas na mesma ordem que no restante da dissertação, ou seja, conforme a ordem em que foram inicialmente enumeradas no Quadro 3-5 da Seção 3.5.
} 
A Figura 6-1 mostra que, no cômputo geral, a prática que apresenta maior Grau de Aplicação Geral é a Reserva de Tarefas, com GAG=5. De fato, a freqüência com que ela é aplicada aparenta ser decorrente da própria imprevisibilidade e do excesso de imprevistos que podem surgir no processo de construção. Para lidar com tal situação, as empresas tendem a já manter uma espécie de "Plano B", de forma a evitar paradas na produção.

Logo abaixo na escala, vêm o Programa de Sugestão e o Kit Completo, ambos com $\mathrm{GAG}=4$. As análises são dadas a seguir:

- Programa de Sugestão: as Empresas A e B já têm um programa efetivamente implantado, mas a Empresa $\mathrm{C}$ nem começou a desenvolvê-lo. A diferença entre as empresas parece decorrer de uma simples questão de iniciativa: nas duas primeiras empresas, houve uma iniciativa por parte da liderança de criar e promover programas de forma corporativa, algo que não ocorreu na terceira.

- Kit Completo: as três empresas sentem a necessidade de garantir um Kit Completo para que a obra transcorra com a devida normalidade, sem que a atividade tenha que ser paralisada ou executada em condições sub-ótimas. Nesse contexto, merece destaque a iniciativa da Empresa $B$, que adotou um check-list a ser preenchido no início da obra para procurar garantir que nenhuma pré-condição deixe de ser satisfeita.

Em seguida, há cinco práticas com $\mathrm{GAG}=3$. Em uma delas, ou seja, no Sistema 5S, tem-se uma aplicação efetiva na Empresa $A$, parcial na Empresa $B$ e nula na Empresa $\mathrm{C}$, sendo tal comportamento explicado pelo mesmo motivo que 0 Programa de Sugestão, ou seja, na diferença na iniciativa por parte das lideranças das empresas em desenvolver a prática. Nas quatro outras práticas, o grau de aplicação se mostra parcial em todas as três empresas para o processo de construção, com as explicações dadas a seguir:

- Procedimentos Habilitadores: As empresas de RDU investigadas demonstram ter, como característica geral, uma preocupação bastante forte com a obediência a padrões técnicos durante o processo de construção de redes, até por causa dos altos riscos operacionais inerentes às falhas que podem ocorrer neste processo. No entanto, não se pode afirmar que tais 
documentos sejam habilitadores, uma vez que nas empresas consideradas ainda prevalece o tradicional paradigma da separação entre quem elabora 0 procedimento e quem o executa.

- Grupos Kaizen: Duas dificuldades se mostraram evidentes, em maior ou menor grau, na aplicação desta prática em todos os casos: primeiro, a iniciativa tem se restringido a apenas algumas áreas da empresa, não havendo uma coordenação corporativa consistente para ampliar sua disseminação; segundo, as pessoas que realmente executam os trabalhos são raramente são envolvidas na condução destes grupos.

- Solução de Problemas: Todas as empresas de RDU apresentam ferramentas estruturadas para a análise de problemas, para direcionar uma busca constante de sua causa-raiz. Contudo, a aplicação das mesmas tem sido bastante restrita, limitando-se quase que exclusivamente à análise de problemas relacionados à segurança da equipe e da operação, sendo esporádicas as aplicações na análise de outros tipos de problemas.

- Lookahead: As três empresas mantêm uma janela de planejamento para suas atividades de construção, e buscam satisfazer as pré-condições enquanto as atividades se encontram nessa janela. $O$ problema é que nem todas as pré-condições são gerenciadas adequadamente: as Empresas $\mathrm{A} e$ $B$ mostraram dificuldade em gerenciar a mão-de-obra e equipamentos contratados, enquanto a Empresa $C$ apresentou problemas com o controle das autorizações de obra. A falta de integração entre os processos de controle dos diferentes recursos parece ser a causa dessas dificuldades.

Continuando a examinar a seqüência de práticas enxutas classificadas em ordem decrescente de GAG, chega-se às seguintes práticas, com GAG igual a 2 ou 1. Tais práticas são aplicadas somente em uma ou duas das empresas e, mesmo assim, de forma apenas parcial:

- Heijunka: A prática de promover o nivelamento do volume de trabalho das equipes parece ser uma preocupação das três empresas, embora cada uma procure obtê-lo de uma forma diferente. Esta idéia ainda se encontra em estágio inicial na Empresa $A$ e num estágio um pouco mais avançado nas Empresas B e C, embora ainda não esteja consolidada nas duas últimas. 
Por outro lado, a idéia do nivelamento em mix de produção, descrita na Seção 3.2.1 como necessária para a plena aplicação do Heijunka, não é considerada em nenhum caso, sendo até um tema desconhecido por parte das equipes consultadas nestas empresas.

- Poka-yoke e Autonomação: Exemplos de aplicação de dispositivos Pokayoke foram identificados nas Empresas $\mathrm{A}$ e $\mathrm{C}$ e de autonomação somente na Empresa A. Porém, tratam-se de aplicações isoladas. Em nenhum dos casos, foi percebida uma verdadeira preocupação por parte da gerência destas empresas em desenvolver e implantar dispositivos ou procedimentos para aplicar estas práticas de forma sistemática.

- SBCE: Um único caso de participação de todas as áreas envolvidas na elaboração de um projeto foi relatado pela Empresa C. Porém, no referido projeto, somente uma solução foi analisada, e não um conjunto de soluções. A experiência se assemelha mais ao que Sobek II; Ward e Liker (1999) descrevem como Engenharia Simultânea Baseada em Pontos do que ao SBCE, ou seja, uma Engenharia Simultânea Baseada em Conjuntos (Seção 3.3.2).

Por fim, existem sete práticas enxutas para as quais nenhuma das três empresas apresentou evidência de aplicação no processo de construção. Uma breve discussão sobre as mesmas e a dificuldade de aplicá-las no contexto da construção de RDUs é apresentada a seguir:

- Fluxo Contínuo / Takt time e Sistema Puxado: Os entrevistados não conseguiram evidenciar situações que se caracterizassem como fluxo contínuo ou como sistema puxado. Estas práticas são percebidas como típicas da manufatura, não sendo conhecida por nenhum entrevistado alguma aplicação prática em empresas de RDU. Uma única empresa - no caso, a Empresa $\mathrm{C}$ - afirma ter tentado aplicar o conceito de sistema puxado na obtenção de materiais para as obras, mas problemas como fornecedores com lead time longo e variável inviabilizaram a iniciativa.

- Setup Rápido: $\mathrm{Na}$ entrevista com o representante da Empresa A, foi visto que o conceito de Setup pode ser adaptado ao contexto da construção de uma RDU como a preparação necessária entre o término de uma tarefa em 
um local e o início da tarefa seguinte em outro local (tempo de desmobilização, deslocamento e mobilização). Neste caso, a prática de Setup Rápido corresponderia à realização desta preparação num período de tempo menor. Porém, nenhuma das empresas investigadas, incluindo a própria Empresa A, tem desenvolvido qualquer esforço de melhoria nesse sentido.

- TPM-AM, TPM-PM e TPM-EM: Não se observou nenhuma evidência de implantação dos pilares do TPEM no processo de construção das três empresas estudadas. O principal argumento para não terem adotado estas práticas é que os equipamentos utilizados no processo de construção são de propriedade da contratada, não havendo controle sobre os mesmos por parte da empresa de RDU.

- Medição e Monitoramento do PPC: A aplicação desta prática não foi identificada em nenhuma empresa de RDU em seu processo de construção. Os gestores das empresas investigadas costumam se basear no plano macro do projeto para controlar a execução, e não no plano micro definido pelo Último Planejador, como prega o Last Planner (ver Seção 3.4.1).

\subsubsection{Grau de Aplicação de práticas enxutas no processo de manutenção}

O Quadro 6-2 apresenta uma tabulação análoga à do Quadro 6-1, porém aplicada aos dados referentes ao processo de manutenção das três empresas de RDU investigadas. 
Quadro 6-2 - Práticas enxutas conforme Grau de Aplicação no processo de manutenção

\begin{tabular}{|c|c|c|c|}
\hline & $\begin{array}{l}\text { Práticas sem nenhuma } \\
\text { evidência de aplicação } \\
(\mathrm{GA}=0) \text {. }\end{array}$ & $\begin{array}{l}\text { Práticas com aplicação } \\
\text { parcial }(G A=1)\end{array}$ & $\begin{array}{l}\text { Práticas com aplicação } \\
\text { efetiva }(G A=2)\end{array}$ \\
\hline 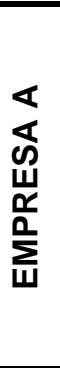 & $\begin{array}{l}\text { Fluxo Contínuo } \\
\text { Sistema puxado } \\
\text { Setup Rápido } \\
\text { Poka-yoke } \\
\text { TPM-AM } \\
\text { TPM-EM } \\
\text { SBCE } \\
\text { Monitoramento PPC } \\
\text { Reserva de Tarefas }\end{array}$ & $\begin{array}{l}\text { Procedimentos habilitadores } \\
\text { Heijunka } \\
\text { Autonomação } \\
\text { Solução de problemas } \\
\text { Grupos kaizen } \\
\text { TPM-PM }\end{array}$ & $\begin{array}{l}\text { Sistema 5S } \\
\text { Programa de Sugestão } \\
\text { Kit Completo } \\
\text { Lookahead }\end{array}$ \\
\hline 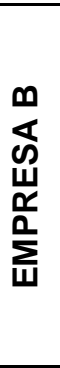 & $\begin{array}{l}\text { Sistema 5S } \\
\text { Fluxo Contínuo } \\
\text { Sistema puxado } \\
\text { Poka-yoke } \\
\text { TPM-AM } \\
\text { SBCE } \\
\text { Monitoramento PPC } \\
\text { Reserva de Tarefas } \\
\text { Lookahead } \\
\end{array}$ & $\begin{array}{l}\text { Procedimentos habilitadores } \\
\text { Heijunka } \\
\text { Setup Rápido } \\
\text { Autonomação } \\
\text { Solução de problemas } \\
\text { Grupos kaizen } \\
\text { TPM-PM } \\
\text { TPM-EM }\end{array}$ & $\begin{array}{l}\text { Programa de Sugestão } \\
\text { Kit Completo }\end{array}$ \\
\hline 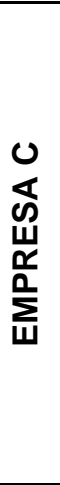 & $\begin{array}{l}\text { Fluxo Contínuo } \\
\text { Programa de Sugestão } \\
\text { TPM-AM } \\
\text { TPM-EM } \\
\text { Kit Completo } \\
\text { Monitoramento PPC } \\
\text { Reserva de Tarefas }\end{array}$ & $\begin{array}{l}\text { Procedimentos habilitadores } \\
\text { Sistema 5S } \\
\text { Heijunka } \\
\text { Sistema puxado } \\
\text { Setup Rápido } \\
\text { Autonomação } \\
\text { Poka-yoke } \\
\text { Solução de problemas } \\
\text { Grupos Kaizen } \\
\text { TPM-PM } \\
\text { SBCE } \\
\text { Lookahead }\end{array}$ & \\
\hline
\end{tabular}

De um modo geral, em seu processo de manutenção, as Empresas A, B e C apresentam padrões de aplicação de práticas enxutas com muitos pontos em comum, embora a Empresa $A$ apresente um maior número de práticas com aplicação efetiva (quatro) e a Empresa $\mathrm{C}$ um maior total geral de práticas com algum grau de aplicação (doze).

Na Empresa A, foram identificadas dez aplicações de práticas enxutas. Dentre elas, destaca-se a aplicação efetiva de quatro delas: Sistema 5S, Programa de Sugestão, Kit Completo e Lookahead. O Sistema 5S e o Programa de Sugestão desta empresa já foram abordados na Seção 6.1.1 e, por terem sido implantados de forma corporativa, têm o mesmo grau de aplicação em ambos os processos. Já no caso do Kit Completo e do Lookahead, foi encontrado um grau de aplicação maior 
no processo de manutenção, em que as tarefas têm uma natureza mais repetitiva, o que possibilitou à equipe de manutenção explorar melhorar estas práticas.

$\mathrm{Na}$ Empresa B também foram identificadas dez aplicações de práticas enxutas neste processo, mas só há evidências de aplicação efetiva para o Programa de Sugestão e o Kit Completo. O Programa de Sugestão, por sua implantação de forma corporativa, alcançou um grau de aplicação comum em ambos os processos da empresa. Já a verificação do Kit Completo é garantida, no processo de manutenção, pelo uso de check lists na execução de atividades de manutenção padronizadas.

Já na Empresa $\mathrm{C}$, foram identificadas aplicações de doze práticas em seu processo de manutenção, mas nenhuma com aplicação efetiva.

O gráfico da Figura 6-2 apresenta as dezenove práticas em ordem decrescente de Grau de Aplicação Geral (GAG) no processo de manutenção. As hachuras em cada coluna distinguem o GA levantado em cada empresa.

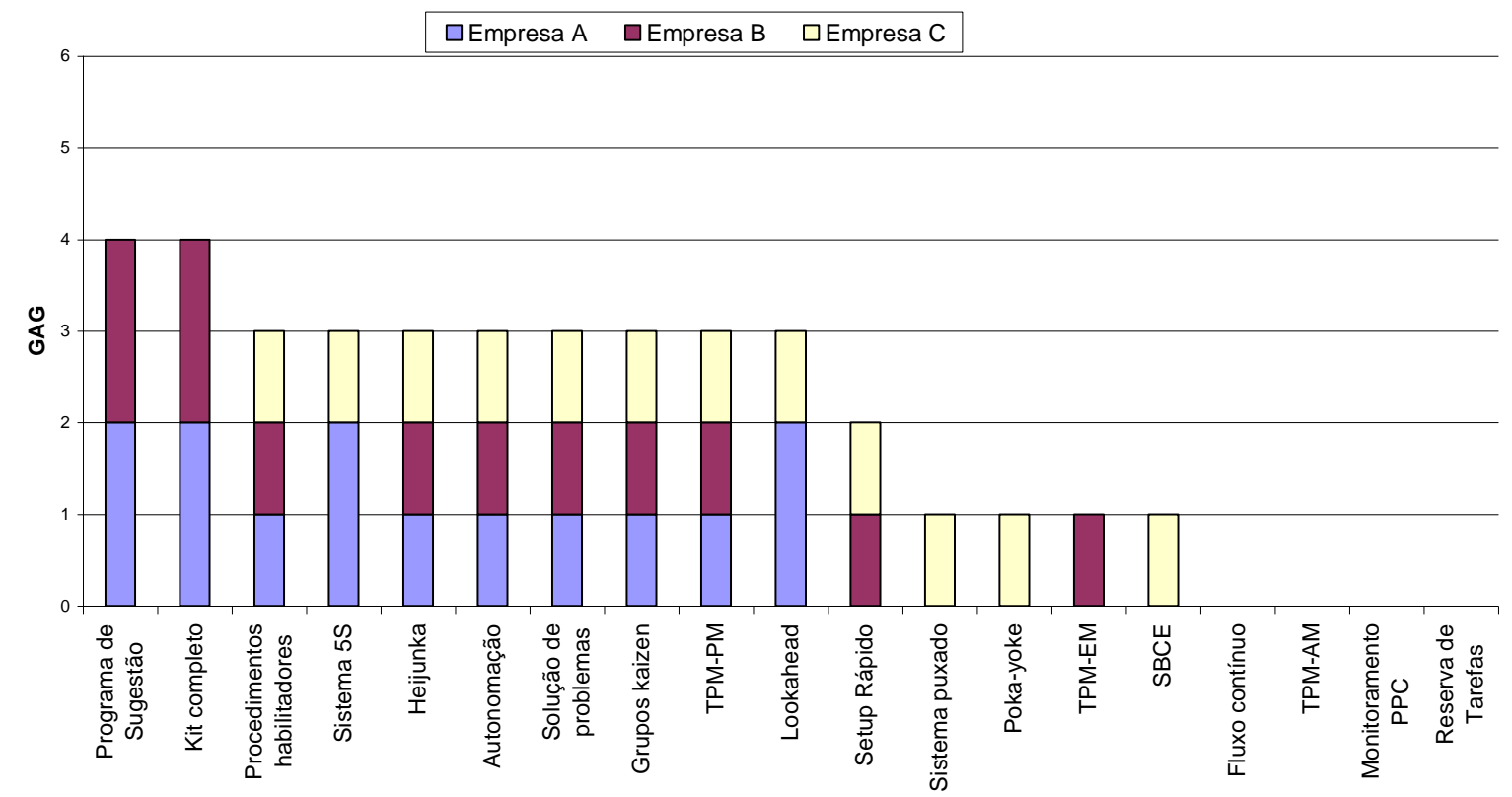

Figura 6-2 - Práticas enxutas conforme Grau de Aplicação Geral (GAG) no processo de manutenção

A Figura 6-2 mostra que, diferentemente do que ocorre no processo de construção, nenhuma prática merece destaque pelo seu grau de aplicação no processo de manutenção nas três empresas da amostra considerada. As práticas para as quais o $\mathrm{GAG}$ é relativamente superior $(\mathrm{GAG}=4)$ são as discutidas a seguir, já efetivamente implantadas nas Empresas $A$ e $B$, embora ainda não tenham sido introduzidas na Empresa C: 
- Programa de Sugestão: Conforme mencionado na Seção 6.1.1, a diferença no Grau de Aplicação está no fato das Empresas A e B já terem tido uma iniciativa de implantação desta prática, enquanto a Empresa $C$ ainda não.

- Kit Completo: Nas Empresas A e B, a disponibilidade de todos os recursos para execução de uma atividade de manutenção é sistematicamente verificada por meio de um check-list. $\mathrm{Na}$ Empresa $\mathrm{C}$, o sistema de informação que terá a mesma finalidade ainda está em desenvolvimento.

Na seqüência, têm-se oito práticas com $G A G=3$. Duas destas práticas são efetivamente aplicadas na Empresa $A$ e parcialmente aplicadas na Empresa $C$, mas ainda sem evidência de aplicação na Empresa B, e são discutidas a seguir:

- Lookahead: A Empresa A apresenta um processo bastante robusto de coordenação dos recursos para atividades de manutenção, contando inclusive com o controle das empresas contratadas por meio de ordens de serviço. A Empresa $\mathrm{C}$ também está organizada de forma semelhante, mas o gestor ainda tem dificuldade em conciliar a verificação dos recursos e a gestão da atividade em si. Já a Empresa $B$ não gerencia os recursos necessários para o processo de manutenção, considerando-os sob responsabilidade da empreiteira.

- Sistema 5S: A Empresa A se destaca nesta prática, apresentando um sistema de organização do local de trabalho robusto e implantado de forma corporativa. A Empresa $C$ também possui iniciativas de implantação desta prática na fase de manutenção, porém de forma mais restrita e dependente da atuação do diretor de cada unidade. Já na Empresa B, esta prática não é observada, o que decorre do fato da maioria das atividades de manutenção ser executada por empreiteiras, as quais acabam não sendo exigidas por contrato a manterem o local de trabalho devidamente organizado.

As outras seis práticas com $\mathrm{GAG}=3$ foram avaliadas com aplicação parcial em todas as três empresas, sem nenhum exemplo de aplicação efetiva:

- Heijunka: A maior dificuldade constatada pelas três empresas na aplicação do Heijunka está no nivelamento do mix de tarefas da manutenção. As três empresas têm suas próprias soluções para nivelamento em volume de trabalho, seja por meio da programação, seja por meio do encaixe da 
manutenção preventiva nos períodos de "vale" da manutenção corretiva. Porém, em nenhum caso, foi observada uma iniciativa para que o conjunto de diferentes tipos de atividades a serem executadas num período de tempo mais curto (dia, semana) seja nivelado. Outra dificuldade encontrada, principalmente nas Empresas $\mathrm{B}$ e $\mathrm{C}$, é que a preocupação com o nivelamento está restrita a alguns setores da empresa, não estando ainda amplamente difundida na organização entre os gestores.

- Procedimentos Habilitadores, Grupos kaizen e Solução de Problemas: Para estas três práticas, os motivos de sua aplicação parcial são os mesmos encontrados para sua aplicação também parcial no processo de construção, descritos na Seção 6.1.1.

- Autonomação: As três empresas já aplicam dispositivos capazes de interromper o fluxo da utilidade no caso de falha, evitando a propagação dos efeitos desta. Nos três casos, porém, tal iniciativa não partiu dos profissionais da própria empresa, pois se tratam de soluções tecnológicas desenvolvidas por fornecedores e aplicadas internacionalmente.

- TPM-PM: Nas três empresas, existe uma tendência pela inclusão de indicadores de confiabilidade na determinação das atividades de manutenção a serem executadas. Porém, ainda não se pode considerar que existe uma aplicação efetiva desta prática: nas Empresas A e B, os dados que servem de base são somente qualitativos, não havendo ainda dados quantitativos à disposição; já na Empresa $\mathrm{C}$, a importância desta aplicação para a racionalização do processo ainda não é percebida em todas as áreas de manutenção da organização.

Há ainda cinco práticas com aplicação parcial em somente uma ou duas empresas ( $G A G=1$ ou 2), em seus processos de manutenção:

- Setup Rápido: Esta prática só é verificada de forma parcial nas Empresas B e $\mathrm{C}$, sendo aplicada às preparações necessárias entre a execução da última tarefa de manutenção em um local e a tarefa seguinte em um local diferente. Em ambos os casos, os gestores criaram diretrizes ou regras de programação para diminuir os tempos de trajeto entre as atividades, atribuindo tarefas geograficamente próximas a cada equipe, algo não 
observado na Empresa A. Porém, em nenhum caso foi constatada a disposição de desenvolver uma iniciativa para racionalizar os processos de desmobilização e de mobilização, além do processo de transporte.

- TPM-EM: Somente a Empresa B aplica esta prática, e de forma parcial: o esforço para criar ou selecionar equipamentos que demandem menos manutenção existe, mas parte somente da área central de Engenharia da empresa, sem considerar o feedback do pessoal de campo.

- Poka-yoke: A Empresa $\mathrm{C}$ foi a única a apresentar um exemplo de dispositivo poka-yoke aplicado no processo de manutenção (descrito na Seção 5.3.2). No entanto, assim como nas aplicações de dispositivos de autonomação, trata-se de uma solução já amplamente adotada por empresas de energia elétrica, que não resultou de um desenvolvimento próprio da Empresa $\mathrm{C}$.

- SBCE: Para esta prática, os motivos de sua aplicação parcial na Empresa C são os mesmos encontrados no processo de construção, descritos na Seção 6.1.1.

- Sistema puxado: Foi identificado apenas um caso de aplicação parcial na Empresa $C$, em que a criação de um sistema puxado para os materiais utilizados na manutenção contribuiu para a diminuição do estoque de peças sobressalentes. Porém, o sistema ainda não está efetivo devido a restrições como o lead time dos fornecedores, que em geral é muito longo, e a burocracia interna para efetuação das compras.

Por fim, as práticas enxutas para as quais nenhuma aplicação pôde ser constatada no processo de manutenção das Empresas A, B e C foram as seguintes:

- Reserva de Tarefas: Nas três empresas, os entrevistados no processo de manutenção alegaram que não há a necessidade de desenvolver uma Reserva de Tarefas. Dada a independência das tarefas neste processo, sempre há uma tarefa de reserva para programar no lugar de uma interrompida ou impossibilitada de iniciar devido a imprevistos.

- Fluxo Contínuo / Takt time: Em nenhum caso ficou evidenciada a aplicação de alguma prática que se baseasse nos conceitos de fluxo contínuo e de takt time. 
- Monitoramento do PPC: Todas as empresas monitoram seus planos de manutenção, mas nenhuma das empresas foca este monitoramento com base no plano criado após a análise das pré-condições.

- TPM-AM: As empresas alegam que não existe propriamente uma equipe de operação que poderia praticar uma manutenção autônoma. Isso porque, diferentemente do que ocorre em outras indústrias, os equipamentos das RDUs operam de forma automática, havendo a necessidade de intervenção humana somente em caso de anomalia (o que já caracteriza uma manutenção).

\subsubsection{Análise comparativa entre os Graus de Aplicação}

Realizando uma análise comparativa entre os Graus de Aplicação Gerais (GAGs) observados para cada prática enxuta no processo de construção e no processo de manutenção, para a amostra de empresas estudadas, chega-se ao gráfico da Figura 6-3.

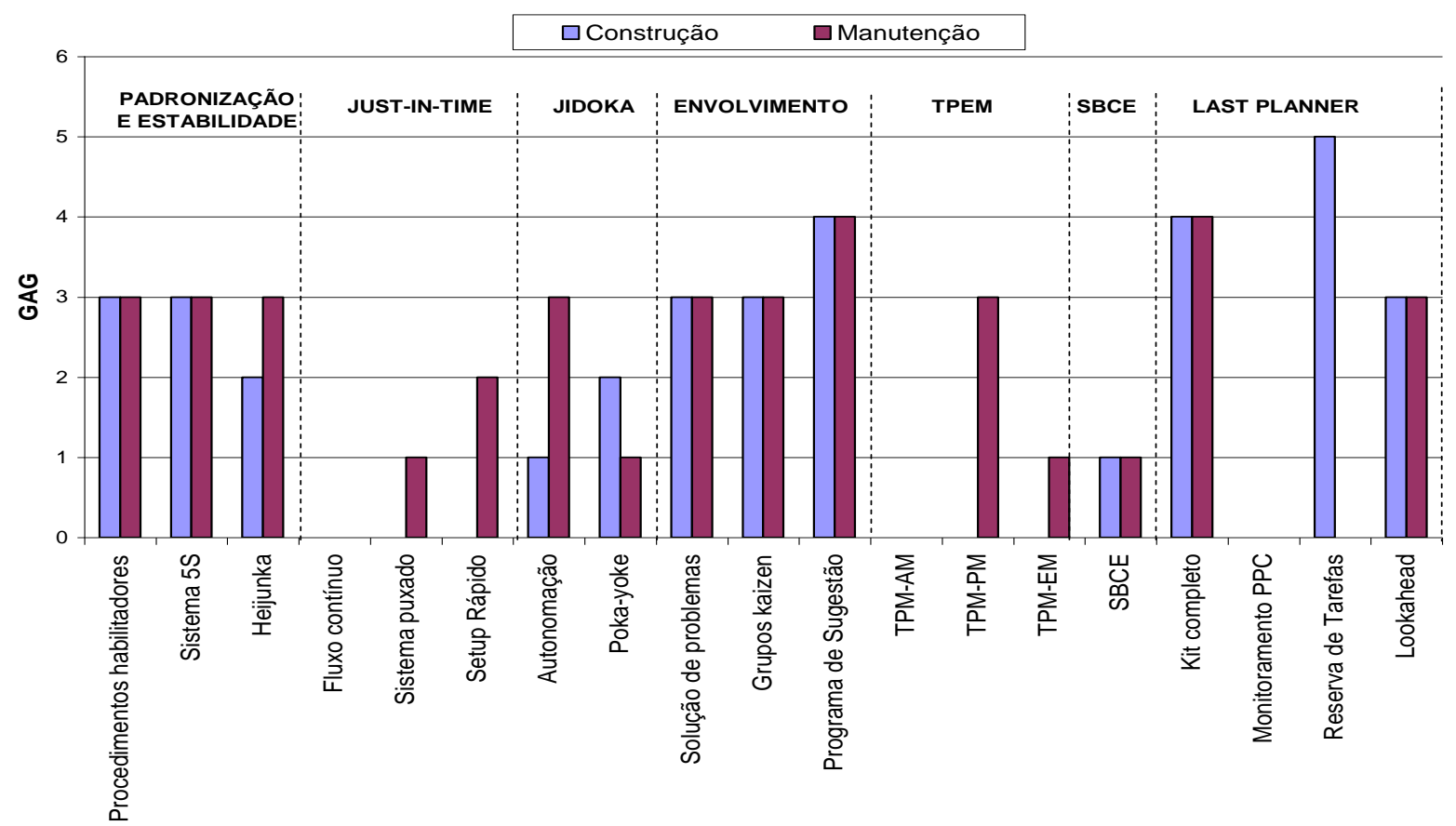

Figura 6-3 - Graus de Aplicação Gerais (GAGs) das práticas enxutas nos processos de construção e de manutenção

A análise do gráfico da Figura 6-3 vem a seguir, dividida conforme subconjuntos de práticas. 


\section{Padronização e estabilidade}

Neste subconjunto, observou-se um mesmo GAG para as práticas Procedimentos Habilitadores e Sistema $5 S$ nos dois processos considerados, ambas em nível intermediário, o que sugere que sua aplicabilidade não depende do processo em questão.

No caso do Heijunka, existe uma pequena diferença a favor do processo de manutenção, que pode ser decorrente da maior facilidade de se nivelar o volume de trabalho na manutenção preventiva, em que as atividades são mais padronizadas e previsíveis, que na construção, que está mais sujeita a imprevistos.

\section{Just-In-Time}

Este subconjunto apresenta Graus de Aplicação Geral nulos no processo de construção, e baixos ou nulos no processo de manutenção. Os exemplos de aplicação encontrados para as práticas Setup Rápido e Sistema Puxado são ainda iniciativas pontuais e isoladas de alguns gestores, não caracterizando propriamente uma maior propensão para sua aplicação.

\section{Jidoka}

As duas práticas do Jidoka - Autonomação e Poka-yoke - mostram graus de aplicação variados, mas sem exemplos de aplicação efetiva. Os exemplos de aplicação parcial remetem a dispositivos desenvolvidos por fornecedores, de uso comum na indústria em questão.

Assim, o fato de um entrevistado ter sido capaz de apontar exemplos de dispositivos, enquanto o outro não o foi, não mostra propriamente uma maior propensão para aplicação na empresa ou no processo em questão. Conseqüentemente, a pequena diferença - para um lado ou para outro - no GAG dessas práticas entre os dois processos pode ser considerada irrelevante.

\section{Envolvimento}

Para as práticas deste subconjunto - Solução de Problemas, Grupos Kaizen e Programas de Sugestão - foi observado um mesmo GAG nos dois processos. A razão disso parece estar na própria natureza das práticas deste subconjunto, geralmente implantadas de forma corporativa em todos os processos da cadeia de valor de uma dada empresa. 


\section{TPEM}

Das três práticas do TPEM, observou-se a aplicação parcial de duas delas, quais sejam, TPM-PM e TPM-EM, apenas no processo de manutenção. Por se tratar de práticas que envolvem principalmente competências e atribuições técnicas da equipe de manutenção, sua aplicação neste processo tende a ser mais freqüente.

Já a prática do TPM-AM consiste em uma exceção, pois sua aplicação não foi observada em nenhuma das três empresas. O principal motivo seria o fato de nas RDUs não existir propriamente a função de operador de produção cujas atribuições poderiam ser ampliadas para incluir a manutenção autônoma (ver Seção 6.1.2).

No processo de construção, as empresas alegam a inaplicabilidade dos três pilares do TPEM, já que a maioria dos equipamentos não pertence a elas, e sim às empreiteiras.

\section{SBCE}

Para a prática do SBCE, também foi observado um mesmo GAG nos dois processos. Nesse caso, a equivalência é esperada, já que a própria natureza do SBCE exige que ambas as áreas (Construção e Manutenção) sejam envolvidas simultaneamente em sua aplicação.

\section{Last Planner}

Para a prática da Reserva de Tarefas foi observado um maior GAG na fase de construção, o que era de se esperar em se tratando de uma prática eminente da abordagem de Construção Enxuta (Seção 3.4.1). Os entrevistados do processo de construção mostraram uma acentuada preocupação em manter uma Reserva de Tarefas, algo que não foi observado no processo de manutenção.

Porém, para as práticas de Kit Completo e Lookahead, que têm a mesma origem, o GAG observado no processo de manutenção foi o mesmo do da construção, o que sugere que as fronteiras do seu campo de aplicação podem extrapolar os limites da atividade para a qual foram criadas.

Já no caso da Medição e Monitoramento do PPC, não foi observada nenhuma aplicação prática, talvez pelo fato de ainda não ser freqüente, no processo de gestão de operações das RDUs, a elaboração de um plano de curto prazo com visão das atividades que podem realmente ser executadas. 


\subsection{Motivação para aplicação de práticas enxutas em RDUs}

A segunda questão de pesquisa (Questão Q2), que é retomada abaixo, visa elucidar as reais motivações que têm levado a gerência das empresas de RDU consideradas a adotar determinadas práticas enxutas:

- Q2: Em que medida a aplicação atual - ou uma possível aplicação futura - de cada prática enxuta é realmente motivada pelo pensamento enxuto?

Para se elucidar a Questão Q2 em relação aos processos considerados, tomam-se como base os Graus de Relação (GR) avaliados nos casos descritos no Capítulo 5. O procedimento de análise é similar ao da Questão Q1: primeiramente, são analisados os dados para o processo de construção e de manutenção separadamente, e em seguida é realizada uma análise comparativa dos resultados encontrados nestes dois processos.

\subsubsection{Grau de Relação de práticas enxutas no processo de construção}

O Quadro 6-3 apresenta as avaliações do Grau de Relação a respeito da motivação para aplicação da prática enxuta considerada no processo de construção, em cada empresa. 
Quadro 6-3 - Práticas enxutas conforme Grau de Relação no processo de construção

\begin{tabular}{|c|c|c|c|}
\hline & $\begin{array}{l}\text { Práticas com nenhuma } \\
\text { relação com o pensamento } \\
\text { enxuto }(\mathrm{GR}=0)\end{array}$ & $\begin{array}{l}\text { Práticas com alguma } \\
\text { relação com o pensamento } \\
\text { enxuto (GR=1) }\end{array}$ & $\begin{array}{l}\text { Práticas com forte relação } \\
\text { com o pensamento enxuto } \\
\text { (GR=2) }\end{array}$ \\
\hline 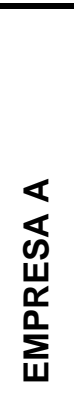 & $\begin{array}{l}\text { Procedimentos habilitadores } \\
\text { Fluxo Contínuo } \\
\text { Sistema puxado } \\
\text { Setup Rápido } \\
\text { Autonomação } \\
\text { Poka-yoke } \\
\text { Solução de problemas } \\
\text { TPM-AM } \\
\text { TPM-PM } \\
\text { TPM-EM }\end{array}$ & Heijunka & $\begin{array}{l}\text { Grupos kaizen } \\
\text { Programa de Sugestão } \\
\text { SBCE } \\
\text { Kit Completo } \\
\text { Monitoramento PPC } \\
\text { Reserva de Tarefas } \\
\text { Lookahead } \\
\text { Sistema 5S }\end{array}$ \\
\hline
\end{tabular}

\begin{tabular}{|c|c|c|c|}
\hline 品 & $\begin{array}{l}\text { Fluxo Contínuo } \\
\text { Sistema puxado } \\
\text { Setup Rápido } \\
\text { Autonomação } \\
\text { Poka-yoke } \\
\text { Solução de problemas } \\
\text { TPM-AM } \\
\text { TPM-EM } \\
\text { Monitoramento PPC }\end{array}$ & $\begin{array}{l}\text { Procedimentos habilitadores } \\
\text { Heijunka } \\
\text { TPM-PM } \\
\text { SBCE } \\
\text { Reserva de Tarefas }\end{array}$ & $\begin{array}{l}\text { Sistema 5S } \\
\text { Grupos kaizen } \\
\text { Programa de Sugestão } \\
\text { Kit Completo } \\
\text { Lookahead }\end{array}$ \\
\hline 峁 & $\begin{array}{l}\text { Fluxo Contínuo } \\
\text { Sistema puxado } \\
\text { Setup Rápido } \\
\text { Autonomação } \\
\text { Poka-yoke } \\
\text { TPM-AM }\end{array}$ & $\begin{array}{l}\text { Procedimentos habilitadores } \\
\text { Heijunka } \\
\text { TPM-PM } \\
\text { TPM-EM } \\
\text { Monitoramento PPC } \\
\text { Reserva de Tarefas }\end{array}$ & $\begin{array}{l}\text { Sistema 5S } \\
\text { Solução de problemas } \\
\text { Grupos kaizen } \\
\text { Programa de Sugestão } \\
\text { SBCE } \\
\text { Kit Completo } \\
\text { Lookahead }\end{array}$ \\
\hline
\end{tabular}

Os argumentos e evidências levantados nas entrevistas mostraram que para a aplicação de boa parte das práticas enxutas no processo de construção, há em geral um alto grau de relação com o pensamento enxuto. O número de práticas enxutas para as quais a motivação para aplicação revela pelo menos alguma relação com o pensamento enxuto foi verificada para as Empresas A, B e C, e o total encontrado foi respectivamente de nove, dez e treze práticas.

Isso significa que os gestores de empresa de RDU entrevistados geralmente reconhecem - independentemente de estarem aplicando ou não a prática considerada - o benefício que a maioria das práticas enxutas pode proporcionar para melhoria da qualidade, diminuição do custo e/ou diminuição do lead time. 
O gráfico da Figura 6-4 apresenta as dezenove práticas em ordem decrescente de Grau de Relação Geral (GRG), variável definida na seção na Seção 4.4.3, no processo de construção. As hachuras em cada coluna indicam a contribuição do GR levantado em cada empresa para o valor total calculado.

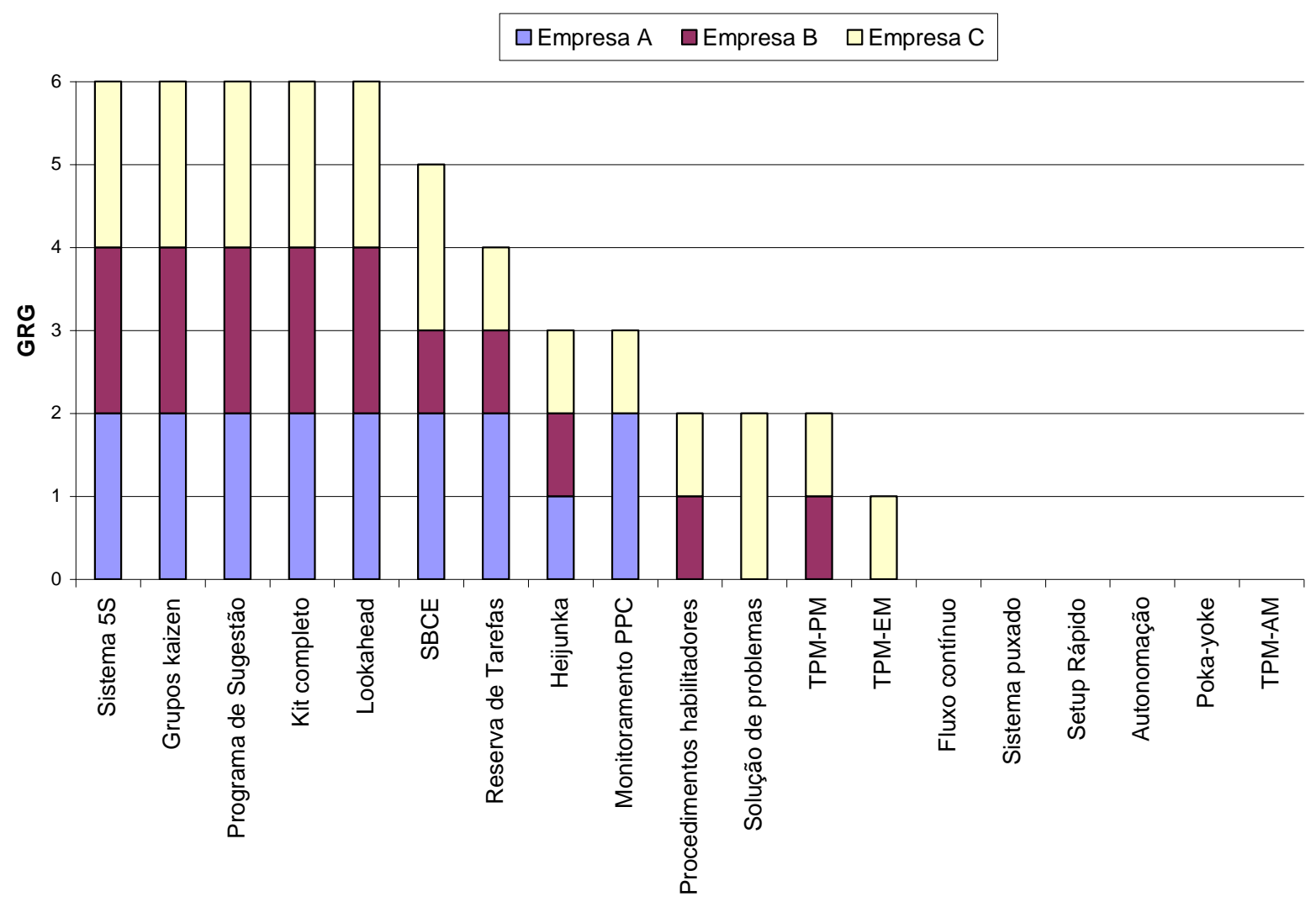

Figura 6-4 - Práticas enxutas conforme Grau de Relação Geral (GRG) no processo de construção

Pela Figura 6-4, percebe-se que cinco práticas atingiram o grau máximo de relação com o pensamento enxuto $(\mathrm{GRG}=6)$ no processo de construção - Sistema 5S, Grupos Kaizen, Programa de Sugestão, Kit Completo e Lookahead. Essas práticas têm em comum o fato de os benefícios de sua aplicação para a melhoria da qualidade, do custo e/ou do lead time serem facilmente identificáveis, até mesmo por gestores de empresas que ainda não aplicam estas práticas.

Logo abaixo, está o $S B C E$, com $G R G=5$. Embora seja uma prática relativamente nova, os entrevistados de todas as empresas mostraram interesse em sua aplicação e entenderam suas vantagens. Apenas no caso da Empresa B foi colocada uma restrição: o entrevistado considera que o SBCE só deve ser aplicado em projetos grandes. 
No caso da Reserva de Tarefas ( $\mathrm{GRG}=4$ ), a relação com o pensamento enxuto também foi visível nos três casos. No entanto, as Empresas $B$ e $C$ cometem o exagero de superdimensionar o tamanho da reserva, mantendo reservas de materiais para vários meses de obra para se proteger de fornecedores com lead times longos e imprevisíveis.

Na seqüência, têm-se o Heijunka e a Medição e Monitoramento do PPC, com $\mathrm{GAG}=3$. O primeiro se apresentou com Grau de Relação parcial nos três casos: os gestores das empresas de RDU analisadas têm em comum o fato de considerarem o nivelamento em volume uma boa prática no processo de construção, mas ainda não entender como poderiam aplicar o nivelamento em mix em suas atividades. Já no caso do segundo, o Grau de Relação na adoção da prática se mostrou alto somente na Empresa $A$, que tem acentuado interesse em adotar tal prática e passar a utilizar o plano micro no monitoramento, para avaliar se a não-execução de tarefas está mais atrelada à falta de pré-condições ou a problemas em campo.

Entre as práticas restantes, apenas Solução de Problemas teve um exemplo de forte relação com a produção enxuta. A aplicação tende a ser estimulada na Empresa $C$, que mostra forte disposição para aplicar análises mais detalhadas a problemas que não sejam ligados à segurança.

Quanto às demais práticas, o GRG encontrado foi bastante baixo, indicando pouco ou nenhum interesse das empresas de RDUs consideradas em utilizá-las para reduzir desperdício e racionalizar o processo de construção.

\subsubsection{Grau de Relação de pratícas enxutas no processo de manutenção}

O Quadro 6-4 apresenta as avaliações do Grau de Relação para cada prática considerada no processo de manutenção das três empresas tomadas como objeto de estudo, de modo análogo ao Quadro 6-3. 
Quadro 6-4 - Práticas enxutas conforme Grau de Relação no processo de manutenção

\begin{tabular}{|c|c|c|c|}
\hline & $\begin{array}{l}\text { Práticas com nenhuma } \\
\text { relação com o pensamento } \\
\text { enxuto }(\mathrm{GR}=0)\end{array}$ & $\begin{array}{l}\text { Práticas com alguma } \\
\text { relação com o pensamento } \\
\text { enxuto (GR=1) }\end{array}$ & $\begin{array}{l}\text { Práticas com forte relação } \\
\text { com o pensamento enxuto } \\
\text { (GR=2) }\end{array}$ \\
\hline 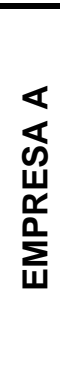 & $\begin{array}{l}\text { Procedimentos habilitadores } \\
\text { Fluxo Contínuo } \\
\text { Autonomação } \\
\text { Poka-yoke } \\
\text { Solução de problemas } \\
\text { TPM-AM } \\
\text { Reserva de Tarefas }\end{array}$ & $\begin{array}{l}\text { Heijunka } \\
\text { Sistema puxado } \\
\text { SBCE }\end{array}$ & $\begin{array}{l}\text { Sistema 5S } \\
\text { Setup Rápido } \\
\text { Grupos kaizen } \\
\text { Programa de Sugestão } \\
\text { TPM-PM } \\
\text { TPM-EM } \\
\text { Kit Completo } \\
\text { Monitoramento PPC } \\
\text { Lookahead }\end{array}$ \\
\hline 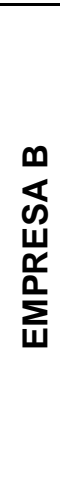 & $\begin{array}{l}\text { Procedimentos habilitadores } \\
\text { Sistema 5S } \\
\text { Fluxo Contínuo } \\
\text { Sistema puxado } \\
\text { Autonomação } \\
\text { Poka-yoke } \\
\text { Solução de problemas } \\
\text { TPM-AM } \\
\text { SBCE } \\
\text { Monitoramento PPC } \\
\text { Reserva de Tarefas } \\
\text { Lookahead }\end{array}$ & $\begin{array}{l}\text { Heijunka } \\
\text { TPM-PM } \\
\text { TPM-EM }\end{array}$ & $\begin{array}{l}\text { Setup Rápido } \\
\text { Grupos kaizen } \\
\text { Programa de Sugestão } \\
\text { Kit Completo }\end{array}$ \\
\hline 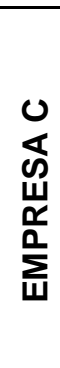 & $\begin{array}{l}\text { Fluxo Contínuo } \\
\text { Autonomação } \\
\text { Poka-yoke } \\
\text { TPM-AM } \\
\text { Reserva de Tarefas }\end{array}$ & $\begin{array}{l}\text { Procedimentos habilitadores } \\
\text { Heijunka } \\
\text { Sistema puxado } \\
\text { TPM-EM } \\
\text { Monitoramento PPC }\end{array}$ & $\begin{array}{l}\text { Sistema 5S } \\
\text { Setup Rápido } \\
\text { Solução de problemas } \\
\text { Grupos kaizen } \\
\text { Programa de Sugestão } \\
\text { TPM-PM } \\
\text { SBCE } \\
\text { Kit Completo } \\
\text { Lookahead }\end{array}$ \\
\hline
\end{tabular}

Os graus de relação das práticas consideradas com o pensamento enxuto se mostraram relativamente altos no processo de manutenção das Empresas A e C, com respectivamente doze e catorze práticas apresentando GR positivo. De forma semelhante à constatada no processo de construção, os entrevistados mostraram reconhecer - independentemente do GA - a potencial vantagem de aplicar as práticas enxutas para melhorar o desempenho em qualidade, custo e/ou lead time.

Na Empresa B, o GR observado no processo de manutenção foi em geral relativamente menor, com apenas sete práticas percebidas pelo entrevistado como um meio de buscar objetivos relacionados com o pensamento enxuto. Esse resultado pode ter sido causado por uma menor receptividade do entrevistado à implantação de novas práticas que demandem mudanças significativas no processo de manutenção. 
O gráfico da Figura 6-5 apresenta as dezenove práticas em ordem decrescente de Grau de Relação Geral (GRG) no processo de manutenção. As hachuras em cada coluna indicam a contribuição do GR levantado em cada empresa para o valor total calculado.

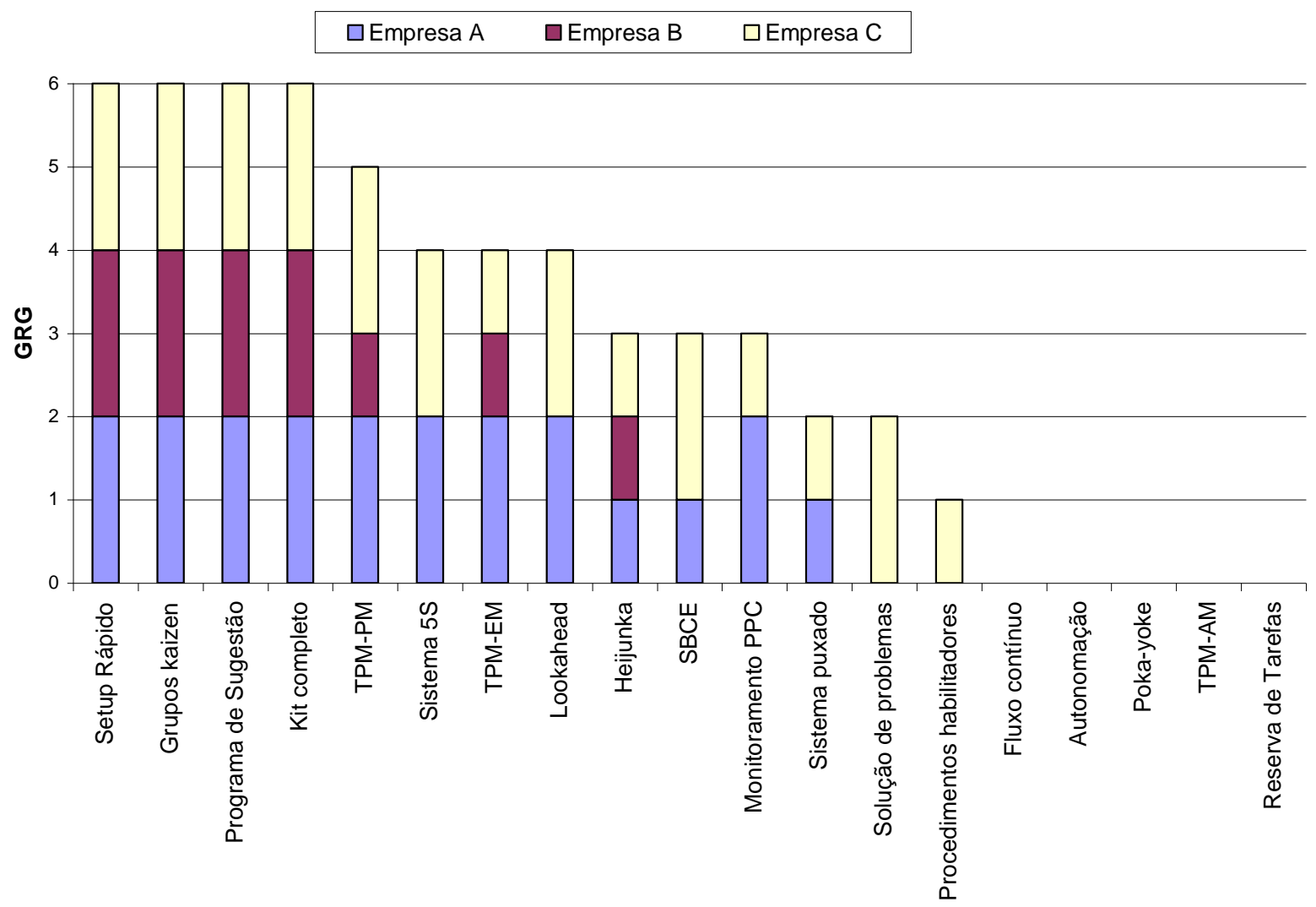

Figura 6-5 - Práticas enxutas conforme Grau de Relação Geral (GRG) no processo de manutenção

Observa-se na Figura 6-5 que para as seguintes quatro práticas foi constatado Grau de Relação Geral máximo ( $G R G=6$ ) no processo de manutenção em todas as empresas: Setup Rápido, Grupos Kaizen, Programa de Sugestão e Kit Completo. Trata-se de práticas cujos benefícios de sua aplicação e cuja relação com o objetivo do pensamento enxuto são facilmente reconhecidos, mesmo por entrevistados de empresas que não as aplicam.

Para três outras práticas, quais sejam, TPM-PM, Sistema $5 S$ e Lookahead, graus de relação máximos foram observados somente nas Empresas A e C. Nestes casos, O GR nulo ou parcial da Empresa B pode ter resultado da falta de receptividade do entrevistado em relação a mudanças em seu cotidiano de trabalho.

Para as práticas do TPM-EM, SBCE, Medição e Monitoramento do PPC e Solução de Problemas, o Grau de Relação máximo só foi percebido em uma 
empresa. A Empresa A manifestou acentuado interesse em aplicar as duas primeiras práticas e acredita nas melhorias que elas possam proporcionar, enquanto que as demais empresas ainda não reconhecem o potencial benefício de sua aplicação. Quanto às práticas do SBCE e Solução de Problemas, somente na Empresa $\mathrm{C}$ foi constatado um GR acentuado.

No caso do Heijunka, o GR foi parcial nas três empresas. Nos três casos, mais uma vez, foram observadas dificuldades para reconhecer os benefícios do nivelamento em mix.

Para as demais sete práticas, em nenhuma empresa foi constatado um alto GR.

\subsubsection{Análise comparativa entre os Graus de Relação}

Segue uma análise comparativa entre os graus de relação verificados para cada prática enxuta nos dois processos, construção e manutenção, para a amostra de empresas de RDU estudadas (Figura 6-6).

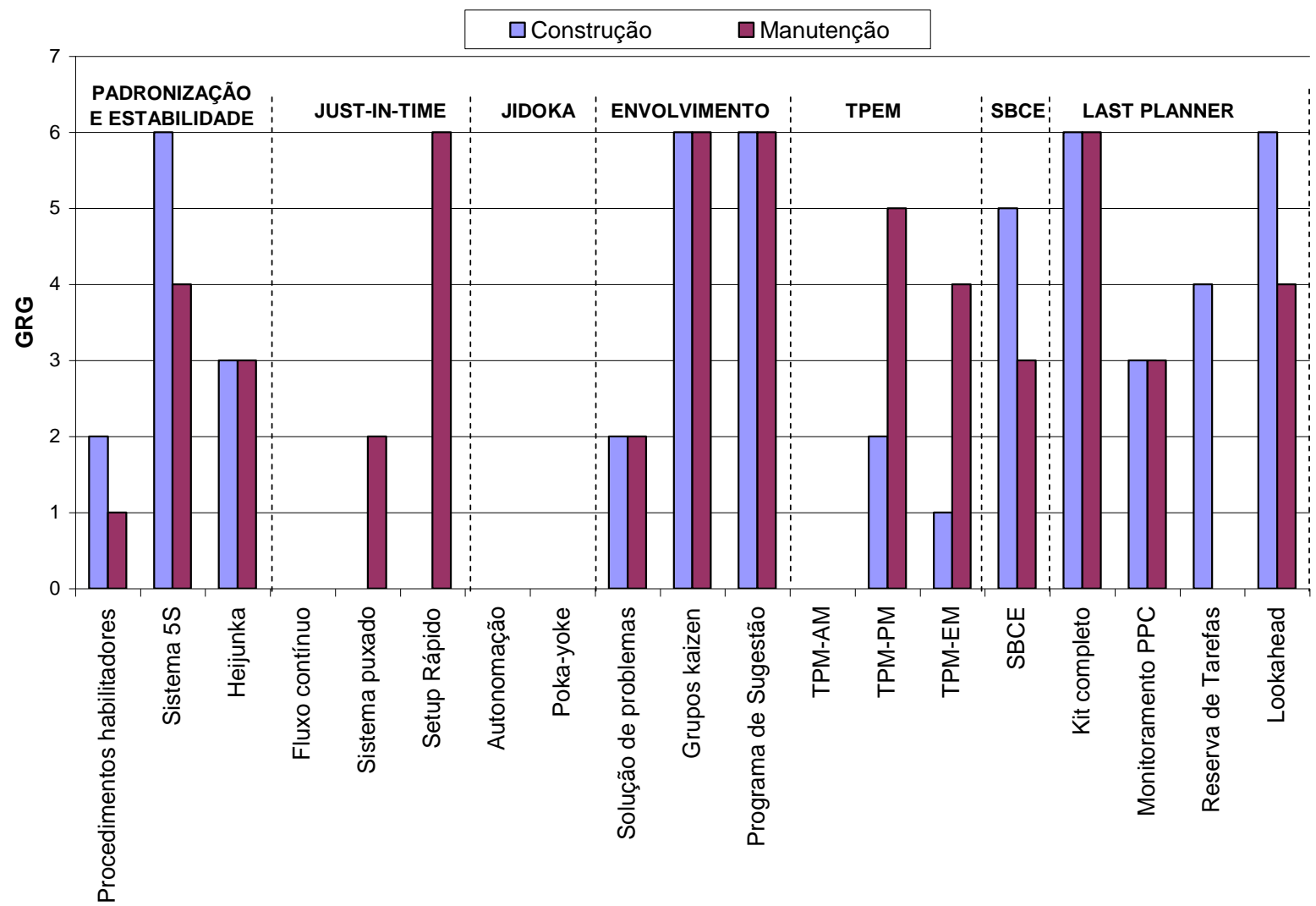

Figura 6-6 - Comparativo entre os Graus de Relação Gerais (GRGs) das práticas enxutas nos processos de construção e de manutenção 
A análise do gráfico da Figura 6-6 vem a seguir, dividida conforme subconjuntos de práticas.

\section{Padronização e estabilidade}

Neste subconjunto, os Graus de Relação Gerais das práticas Procedimentos Habilitadores e Sistema $5 S$ são ligeiramente maiores no processo de construção que no processo de manutenção, enquanto o do Heijunka é o mesmo nos dois processos. Essa realidade, no entanto, parece estar mais relacionada com a receptividade dos entrevistados a novas práticas de racionalização dos processos do que à aplicabilidade em si de cada prática nos processos considerados.

\section{Just-In-Time}

O GRG do Fluxo Contínuo é nulo em ambos os processos. Dada a suposta complexidade das tarefas, que a cada dia são realizadas atividades diferentes, e sempre em locais diferentes, em nenhuma empresa das empresas foi possível identificar uma aplicação desta prática em suas atividades.

Já no caso do Sistema Puxado, alguma relação foi observada no processo de manutenção, mas ainda bastante fraca.

Por fim, no Setup Rápido, todos entrevistados do processo de manutenção mostraram interesse e disposição em adaptar esta prática ao seu contexto, enquanto os do processo de construção alegaram dificuldades.

\section{Jidoka}

O GRG nulo de ambas as práticas deste subconjunto (Autonomação e PokaYoke) nos dois processos considerados sugere que, não obstante alguns exemplos de sua aplicação tenham sido observados, tais exemplos não evidenciam uma efetiva preocupação com o conceito do Jidoka para evitar desperdícios. Em todos os casos, a implantação dos exemplos de aplicação identificados tem sido especialmente motivada pela necessidade de buscar melhorias na segurança dos processos em empresas de RDU.

\section{Envolvimento}

O GRG das três práticas de envolvimento, quais sejam, Solução de Problemas, Grupos Kaizen e Programas de Sugestão, foi avaliado igual nos dois processos. Isso 
se deve ao fato dessas práticas terem sido introduzidas e desde então promovidas nas empresas consideradas de forma corporativa.

\section{TPEM}

O GRG das de TPM-PM e TPM-EM se mostraram maiores no processo de manutenção que no processo de construção. Isso se justifica pelo fato dos equipamentos usados no primeiro serem de propriedade da empresa, exigindo assim um maior controle, enquanto os do segundo pertencem geralmente às empreiteiras.

Já o GRG da prática de TPM-AM foi avaliado como nulo, pelo mesmo motivo discutido e alegado na Seção 6.1.3, relacionado ao Grau de Aplicação: a inexistência de operadores de produção a quem a função de manutenção autônoma pudesse ser atribuída.

\section{SBCE}

No caso do SBCE, o seu GRG no processo de construção foi avaliado como ligeiramente maior que no processo de manutenção. Porém, há de se levar em conta que a efetiva prática do SBCE precisa ser articulada de forma corporativa, não podendo ser aplicada em desenvolvimento de projetos sem o envolvimento dos responsáveis de todos os setores envolvidos. Assim, a diferença observada parece estar relacionada à receptividade de cada entrevistado em relação a esta prática, e não a uma eventual diferença de aplicabilidade nos processos.

\section{Last Planner}

O Grau de Relação de duas das quatro práticas do Last Planner, quais sejam, Kit Completo e Monitoramento do PPC, foi avaliado como igual nos dois processos, enquanto que para a prática do Lookahead foi identificada uma ligeira diferença a favor do processo de construção.

A única prática do Last Planner para a qual não houve equilíbrio entre os graus de relação verificados nos dois processos é a Reserva de Tarefas. Os gestores do processo de construção mostraram interesse em manter a reserva, de forma a evitar paradas no fluxo de execução de suas tarefas. Já os do processo de manutenção não mostraram o mesmo interesse, alegando que a Reserva de Tarefas já existe por natureza do processo, não sendo necessário criá-la. 


\subsection{Aplicabilidade das Práticas Enxutas em RDUs}

A terceira questão (Questão Q3) que é retomada abaixo, examina a aplicabilidade ou potencial de aplicação das práticas enxutas no contexto das RDUs:

- Q3: Quais das práticas da produção enxuta são aplicáveis nos processos de construção e manutenção de empresas de RDU, levandose em conta o objetivo de eliminação do desperdício?

Conforme visto na Seção 4.1, a elucidação da Questão Q3 deve se apoiar numa análise crítica dos dados levantados e discutidos na consideração das Questões Q1 e Q2 (Seções 6.1 e 6.2). Se para uma dada prática enxuta foram observados graus de aplicação e de relação positivos em um dado processo em pelo menos uma empresa, admite-se que aquela prática seja aplicável no processo considerado, com adaptação na forma como tem sido implementada ou não. No entanto, se ambos os graus forem nulos, tal prática pode não ser aplicável àquele processo, mas não necessariamente, pois outros fatores, como desconhecimento, falta de recursos ou desinteresse podem também ter influído no resultado.

Uma análise de aplicabilidade de cada uma das práticas enxutas no contexto de cada um dos processos é dada a seguir:

\section{Procedimentos Habilitadores}

A utilização de Procedimentos Habilitadores é uma prática aplicável em ambos os processos nas empresas de RDU. De fato, os resultados mostram que o uso de procedimentos escritos e detalhados é comum, até devido ao risco ocupacional e operacional envolvido em suas atividades. No entanto, para a efetiva aplicação desta prática, duas dificuldades devem ser superadas:

- Deve-se reduzir a distância entre quem elabora o procedimento (Engenharia) e quem o executa (Operação), fazendo com que os últimos participem mais do desenvolvimento dos procedimentos que irão aplicar.

- Deve-se trabalhar para que os procedimentos descrevam como fazer as atividades de forma mais rápida, mais barata e com maior qualidade, e que não foquem somente no que se deve fazer ou não fazer para evitar acidentes. 


\section{Sistema 5S}

A atividade de organizar os instrumentos de trabalho de forma a manter uma gestão visual é considerada benéfica para qualquer processo produtivo, o que pode ser demonstrado pelo alto grau de relação constatado em praticamente todas as entrevistas.

Para que a implementação desta prática seja bem sucedida, é necessário o desenvolvimento de um programa de forma corporativa - como foi realizado na Empresa A - com atenção especial ao quinto S (shitsuke), ou seja, assegurar que o 5S crie raízes na empresa, mantendo um ambiente de trabalho estável e um processo constante de melhoria contínua.

\section{Heijunka}

O nivelamento em volume mostra-se aplicável tanto ao processo de construção quanto ao de manutenção. Cada empresa estudada vem desenvolvendo suas próprias soluções para tornar o volume de seus processos produtivos mais nivelados no tempo, evitando-se períodos de ociosidade ou sobrecargas.

No entanto, não foi identificada nenhuma aplicação prática de um nivelamento em mix, ou seja, uma programação de produção de modo que os mesmos tipos de tarefas sejam executados em períodos de tempo mais curtos. No processo da construção, a questão unicidade dos trabalhos a serem executados (Seção 2.4.1) pode tornar o nivelamento em mix dificilmente aplicável. Já no caso da manutenção, como as atividades têm uma natureza mais repetitiva, acredita-se que a aplicação do conceito seja possível, embora não tenha sido observada nenhuma evidência nesse sentido nos casos estudados.

\section{Fluxo contínuo}

Não foi observada nenhuma aplicação prática de fluxo contínuo nas empresas estudadas, e nenhum gestor entrevistado considerou a mesma aplicável aos seus processos. O principal motivo disso seria o fato da produção ocorrer em campo, e então como em cada dia se trabalha em um local diferente, não haveria como estabelecer uma linha de produção como na manufatura.

Porém, é possível adaptar a implementação do conceito de fluxo contínuo aos contextos em questão. Tanto no processo de construção quanto no de manutenção, 
embora não haja propriamente uma linha de produção, existem determinadas seqüências de tarefas desempenhadas pelas equipes que são mais constantes, como a seguinte seqüência típica na construção de redes de gás natural: sinalização de área, abertura de vala, colocação de tubos, fechamento de valas e recomposição. Assim, a idéia de programá-las em um fluxo e estabelecer um ritmo adequado diminuiria a quantidade de trabalhos em andamento, representados, por exemplo por valas abertas aguardando recomposição, o que equivaleria ao estoque de material em processo ${ }^{29}$ na manufatura.

\section{Sistema puxado}

No processo de construção, foram encontrados graus de aplicação e de relação nulos para a prática de sistema puxado em todas as empresas. De fato, o sistema puxado tal como originalmente desenvolvido para a manufatura mostra-se de difícil aplicação em ambientes de construção, tendo sido justamente essa a razão para que Ballard e Howell (1998) desenvolvessem o Last Planner, visto como uma adaptação do sistema puxado que leva em conta as particularidades da construção (Seção 3.4.1). Assim, pode-se dizer que o Sistema Puxado é aplicável ao processo de construção, desde que adaptado.

Já no processo de manutenção, os graus de aplicação e de relação observados para a prática do sistema puxado foram parciais em algumas empresas. Neste processo, existe um potencial de aplicação relativamente maior para tal prática, já que as atividades têm uma natureza mais repetitiva. Para tanto, as empresas devem desenvolver a prática, que ainda é incipiente para empresas de RDU, e vencer barreiras que impedem seu correto funcionamento, como por exemplo a burocracia encontrada em algumas empresas para compra de novos materiais e o lead time longo e incerto dos fornecedores.

\section{Setup Rápido}

Tanto o Grau de Aplicação quanto o Grau de Relação se mostraram maiores no processo de manutenção que no processo de construção. $O$ principal motivo parece estar relacionado à necessidade maior da equipe de manutenção em se movimentar entre frentes de trabalho em um mesmo dia, tendo que se preocupar,

\footnotetext{
${ }^{29}$ Também conhecido como Work-In-Progress (WIP)
} 
portanto, com as atividades entre o término da tarefa de manutenção em um local e o início da tarefa seguinte em outro local. Na construção, conforme constatado nas entrevistas, ocorre menor movimentação entre frentes de trabalho em um mesmo dia, havendo menor impacto do tempo de setup na produtividade do processo em um único dia.

Porém, vale lembrar que o processo de construção também inclui processos de setup, entre eles a mobilização no início de um dia de trabalho, a desmobilização ao final do dia e a movimentação entre locais de trabalho. Sendo assim, a prática do Setup Rápido também poderia trazer melhorias a este processo.

\section{Autonomação e Poka-yoke}

Estas duas práticas se mostram aplicáveis a qualquer processo produtivo, já que, com alguma criatividade, é possível criar meios ou dispositivos capazes de interromper o processo na ocorrência de falhas (autonomação) ou evitar que tais falhas ocorram (Poka-yoke). No entanto, para que ambas possam ser aplicadas nos processos de construção e de manutenção das empresas estudadas, foram encontradas duas barreiras que devem ser rompidas:

- Os profissionais das empresas de RDU devem ser estimulados e capacitados para também buscarem o desenvolvimento de dispositivos de autonomação ou poka-yoke, e não depender somente de soluções disponibilizadas no mercado pelos seus fornecedores.

- As soluções de autonomação e poka-yoke devem levar em conta não só os problemas relacionados à segurança operacional, mas também aqueles que impactem em qualidade, custo ou lead time.

\section{Solução de Problemas}

Os métodos de Solução de Problemas para buscar a causa-raiz dos problemas e atuar na sua remoção constituem uma prática aplicável aos processos de construção e manutenção de RDU, e inclusive têm sido bastante utilizados nos processos estudados. Porém, pelo que foi observado, sua aplicação tem sido muito direcionada à investigação de problemas relacionados à segurança.

Para efetivamente aplicá-los como uma prática enxuta, eles devem ser também aproveitados no tratamento de problemas relacionados à qualidade, custo e lead 
time. Em outras palavras, deve-se investigar não só a causa-raiz de um acidente, ou de uma condição insegura, mas também a de problemas como produto sem qualidade, estouro de orçamento ou atraso na execução de cronograma que resultam em desperdícios.

\section{Grupos Kaizen e Programa de Sugestão}

Ambas são práticas aplicáveis em qualquer situação, sempre que se pretende melhorar um processo. De fato, algumas das empresas estudadas mostraram já ter iniciativas no sentido de aplicar tais práticas, enquanto as outras mostraram interesse em aplicá-las no futuro, sempre com foco na melhoria dos processos.

\section{TPM-AM}

No processo de construção, a prática do TPM-AM pode ser aplicada, dando-se aos operadores dos equipamentos de construção alguma autonomia para manutenção de seus equipamentos. Para tanto, as empresas de RDU devem quebrar alguns paradigmas: primeiro, a idéia de que a contratada é a única responsável pela manutenção de seus equipamentos, não sendo necessária qualquer ação por parte da contratante; segundo, a alegação de que restrições na legislação trabalhista inviabilizam a participação de operadores de equipamentos no exercício de cuidados básicos de manutenção autônoma.

Já no processo de manutenção, a prática do TPM-AM realmente não se mostrou aplicável. Neste caso, o motivo alegado pelas três empresas é bastante plausível: não faz sentido falar-se em manutenção autônoma num processo em que todos já têm a manutenção como principal função.

\section{TPM-PM e TPM-EM}

A aplicabilidade das práticas do TPM-PM e do TPM-EM é alta em ambos os processos, mas no processo de manutenção ela é relativamente maior. O motivo é que, no processo de manutenção, a própria RDU é o principal equipamento a ser mantido, e, sendo assim, sua disponibilidade e condições de operação impactam diretamente na distribuição da utilidade aos clientes.

\section{SBCE}

O potencial de aplicação do SBCE é alto no desenvolvimento de um novo projeto de construção, envolvendo também a equipe de manutenção e outras áreas 
das empresas de RDU consideradas. Isso foi evidenciado pelo interesse despertado na maioria dos entrevistados ao tomarem conhecimento desta prática enxuta, embora - até por ser uma prática pouco conhecida - nenhum dos entrevistados tenha apresentado um exemplo de efetiva aplicação.

\section{Kit Completo e Lookahead}

Os graus de aplicação e de relação destas duas práticas são altos em ambos os processos, o que sugere uma alta aplicabilidade no contexto em questão. Algumas ferramentas efetivamente utilizadas na execução destas práticas foram identificadas, tais como o check list para garantir o Kit Completo e o sistema de informação para o planejamento e controle nos moldes do Lookahead.

\section{Monitoramento do PPC}

O monitoramento do PPC é aplicável nos processos de construção e de manutenção das empresas de RDU. Percebe-se, no entanto, que atualmente a aplicação desta prática está limitada à consideração do plano macro do projeto, e não de um plano mais detalhado elaborado pelo Último Planejador, que leve em conta as atividades que a equipe realmente é capaz de executar, dadas as précondições. Acredita-se que isso se deve ao desconhecimento, por parte dos gestores entrevistados, dos princípios do Last Planner (Seção 3.4.1) e da correta forma de planejamento e controle por meio desta prática.

\section{Reserva de Tarefas}

No processo de construção, foi constatado que os graus de aplicação e relação desta prática são altos. No entanto, para que sua aplicação possa ser considerada efetivamente enxuta, as empresas devem limitar o seu estoque de materiais para algumas semanas de obra e não alguns meses, como foi verificado.

No processo de manutenção, não se observou aplicabilidade para a prática da Reserva de Tarefas. Isso se deve ao fato da quantidade de tarefas executáveis que podem ser alocadas para uma equipe de manutenção geralmente já ser suficiente, não sendo necessária maior preocupação a respeito disso para fins de programação das atividades.

Os resultados quanto à aplicabilidade das práticas enxutas estão organizados na Figura 6-7. Verificou-se que há aplicabilidade para todas as dezenove práticas 
em pelo menos um dos processos investigados, sendo que a maioria pode ser aplicada em ambos.

A Figura 6-7 mostra que as práticas consideradas podem ser divididas em três categorias:

- Práticas enxutas com potecial de aplicação relativamente maior no processo de construção (primeira coluna);

- Práticas enxutas com potencial de aplicação semelhante em ambos os procesos (segunda coluna);

- Práticas enxutas com potencial de aplicação maior no processo de manutenção (terceira coluna).

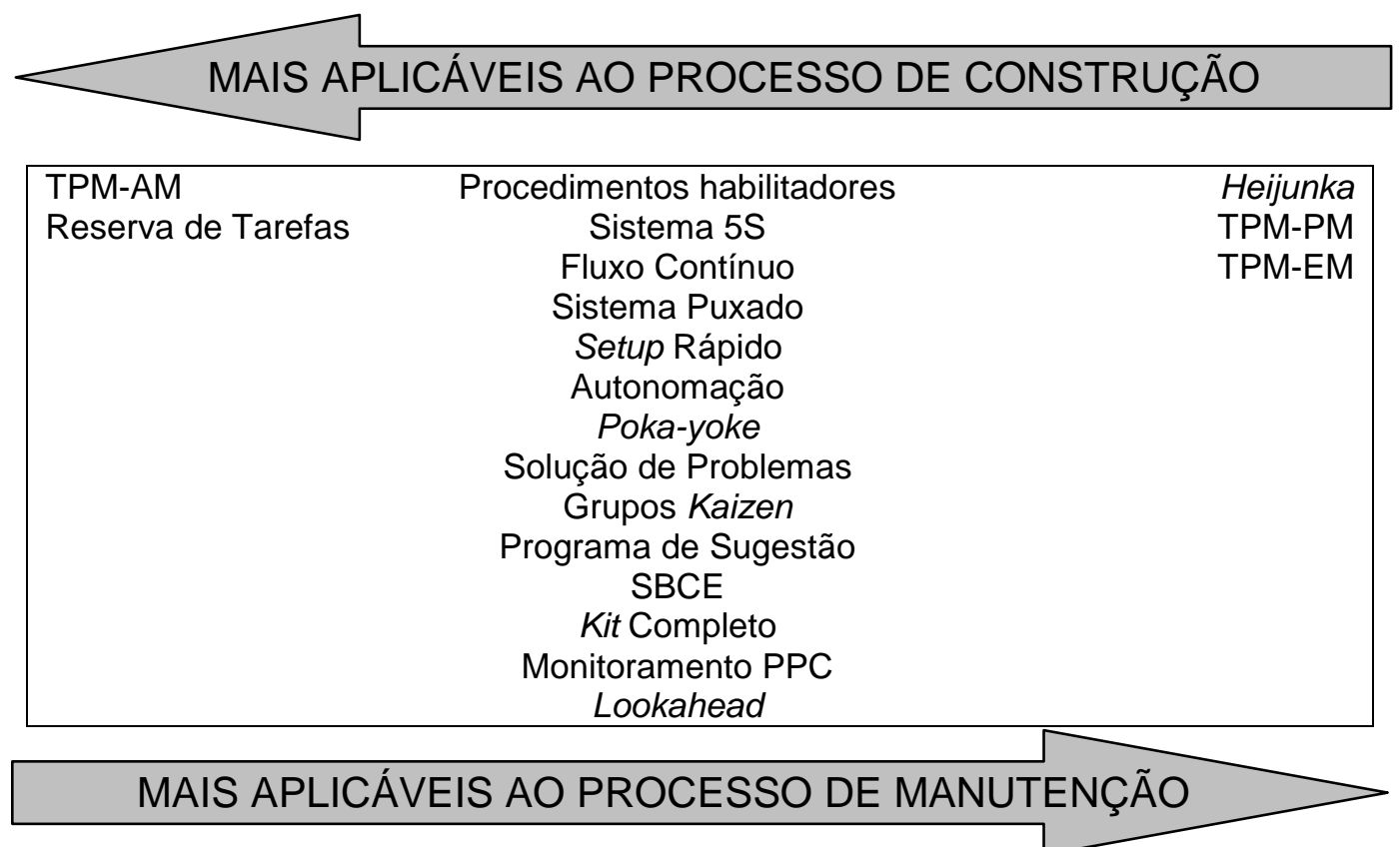

Figura 6-7 - Aplicabilidade das práticas enxutas nos processos de construção e manutenção

\subsection{Discussão}

Os dados da Figura 6-7 mostram que, em geral, a aplicabilidade das práticas de produção enxuta consideradas é alta nos processos estudados das RDUs.

Dentre as práticas enxutas consideradas neste trabalho, merecem destaque as práticas dos subconjuntos Padronização e Estabilidade, Just-In-Time, Jidoka e Envolvimento. De fato, ao descreverem os principais elementos da produção enxuta e incluí-los no modelo da Casa da Produção Enxuta (Seção 3.2), autores como 
Ohno (1997), Liker (2005) e Dennis (2008) não fazem diferenciação quanto ao tipo de processo em que os mesmos podem ser aplicados. Assim, os resultados da presente pesquisa sugerem que as práticas enxutas incluídas nestes subconjuntos sejam aplicáveis a ambos os processos estudados.

Nesses quatro subconjuntos, as práticas para as quais foi constatada uma maior dificuldade de aplicação e mesmo de adaptação nas RDUs foram Heijunka e Sistema Puxado, principalmente no processo de construção.

No caso do Heijunka, algumas soluções foram até encontradas tanto no processo de construção quanto no processo de manutenção das empresas de RDU, mas sempre visando o nivelamento em volume. Verificou-se que existe uma dificuldade maior para se tentar o nivelamento em mix no processo de construção, pois a unicidade das tarefas (ver Seção 2.4.1) pode tornar o nivelamento em mix dificilmente aplicável.

No caso do Sistema Puxado, sua aplicação tal como foi desenvolvido para a manufatura realmente mostra-se de difícil aplicação em ambientes de construção, sendo mais apropriado nesse ambiente buscar a implantação das práticas do Last Planner.

Passando-se ao subconjunto do TPEM, percebe-se que existe um potencial de aplicação maior para duas de suas práticas no processo de manutenção, quais sejam: TPM-PM e TPM-EM. Este resultado reforça o argumento de autores como Abdulmalek, Rajgopal e Needy (2006) e Ha (2007), que defendem que a aplicabilidade das práticas do TPM - e conseqüentemente as do TPEM - aumenta conforme a atividade se assemelha a uma indústria de processo contínuo (ver Seção 3.4.2). Assim, sendo as características da RDU, na fase de operação em que ocorre o processo de manutenção, semelhantes às das indústrias de processo contínuo (Seção 2.4.2), é de se esperar que a aplicabilidade das práticas do TPEM seja maior.

O mesmo não ocorre em relação ao TPM-AM (Manutenção Autônoma), dada a característica dos equipamentos utilizados na fase de operação da RDU dispensarem 0 trabalho de operadores, por serem automatizados e assim requererem a intervenção humana somente para atividades de manutenção corretiva ou planejada. 
Em relação ao SBCE, sua aplicabilidade é visível no contexto do desenvolvimento de um novo projeto de construção em empresas de RDU. Nota-se que, no caso do SBCE, não há necessidade de se comparar sua aplicabilidade na construção e na manutenção, já que pela sua própria concepção sua aplicação exige o envolvimento de todas as áreas na execução de um projeto, o que em empresas de RDU inclui os responsáveis por estes dois processos.

Já no caso das práticas do Last Planner, a pesquisa realizada revelou um atributo interessante do mesmo. Conforme visto na Seção 3.4.1, o Last Planner foi desenvolvido de forma a lidar com as particularidades da construção levantadas por Koskela $(1999,2000)$ e descritas na Seção 2.4.1. Sendo assim, esperava-se que as práticas que derivam do mesmo fossem aplicáveis mais especificamente ao processo de construção de RDU. Porém, confirmou-se que boa parte de suas práticas - Kit Completo, Lookahead e Monitoramento do PPC - é também aplicável, da mesma forma, no processo de manutenção. A única exceção é a prática de Reserva de Tarefas, de fato aplicável somente no processo de construção.

A razão disso pode estar relacionada às características comuns encontradas nos processos de construção e de manutenção de RDU. Como ambos são executados em campo, a garantia de disponibilidade de todos os recursos e/ou do atendimento de todos os requisitos antes do início da execução da tarefa (Kit Completo) se mostra indispensável tanto em um quanto em outro, assim como o planejamento de médio prazo para garantir esses recursos (Lookahead) e o monitoramento da disponibilidade dos mesmos e seu impacto na execução das atividades (Monitoramento do PPC). Nota-se que tais práticas podem até ser consideradas mais fáceis de executar no processo de manutenção, devido à sua maior previsibilidade de suas atividades.

A prática da Reserva de Tarefas Executáveis, relacionada ao Last Planner, consiste em uma exceção. Como uma atividade de manutenção geralmente não depende da outra, a equipe de manutenção de RDU já tem à sua disposição uma Reserva de Tarefas para adiantar caso ocorra algum problema que impeça o cumprimento do que estava planejado. Assim, não existe a necessidade de se prever especificamente uma Reserva de Tarefas no processo de manutenção, tal como na construção. 


\section{Conclusão}

Conforme estabelecido na Seção 1.2, o objetivo desta dissertação foi analisar a Rede de Distribuição de Utilidade (RDU) como sistema produtivo verificando possíveis meios para se melhorar a produtividade de seus processos e, assim, proporcionar maior qualidade, menor custo e menor prazo de entrega ao cliente.

Considerando-se a escassez de ferramentas desenvolvidas especificamente para a melhoria da produtividade neste setor, optou-se por examinar as práticas de produção enxuta já consagradas em outros setores da economia, como as indústrias de manufatura, construção e processo contínuo, descritas ao longo do Capítulo 3, e investigar seu potencial de aplicação no contexto das RDUs. Em relação às práticas de produção enxuta aplicadas em indústrias de manufatura, não foram escolhidas somente aquelas aplicáveis ao processo de produção em si, mas também a processos que dão suporte ao mesmo, como a manutenção e o desenvolvimento de novos produtos, devido à sua importância no setor de RDU observada durante a análise de sua cadeia de valor.

As análises realizadas por meio de estudos de caso indicam que a maioria das práticas pode ser aplicada no contexto das RDUs e, com raras exceções, sua aplicabilidade é verificada nos dois processos estudados, ou seja, na construção e na manutenção de redes.

No entanto, para aplicá-las efetivamente, é necessário que as empresas de RDU superem algumas barreiras hoje presentes.

A primeira é que muitas das práticas ainda são aplicadas visando-se exclusivamente a segurança operacional da rede e/ou a segurança ocupacional dos profissionais da equipe. A aplicação com este foco deve certamente continuar, mas pode-se também passar a utilizar as mesmas práticas com o objetivo de melhorar a qualidade, custo ou lead time nos processos considerados. Um exemplo é a Solução de Problemas: todas as empresas mostraram possuir ferramentas para investigar acidentes envolvendo seus funcionários e suas redes; sendo assim, elas poderiam estender a aplicação da mesma ferramenta à investigação de problemas que impedem as atividades de serem executadas, gerando atrasos ou custos desnecessários. 
Outra dificuldade está na separação, muitas vezes observada, entre quem executa a atividade e quem pensa no como tal atividade deve ser executada, ou ainda no como resolver os problemas em relação à mesma. Esta separação, típica em empresas que seguem os princípios de gestão Taylorista/Fordista (ver Seção 3.2.1), diverge da abordagem mais participativa recomendada pelos participantes da produção enxuta. As empresas de RDU que desejarem seguir o mesmo caminho devem ampliar a inserção dos operadores que atuam nos processos considerados em iniciativas de racionalização das atividades que executam.

Uma terceira dificuldade consiste no envolvimento de toda a equipe da empresa para a introdução, promoção e aplicação de práticas enxutas. Observa-se que, para a efetiva aplicação das práticas enxutas, é importante que a iniciativa venha da alta direção e seja disseminada em todos os níveis hierárquicos. A efetividade disso foi observada, por exemplo, no esforço de implantação do Sistema $5 S$ da Empresa A e na promoção do Programa de Sugestão das Empresas A e B, implantados de forma corporativa. Iniciativas tomadas de forma isolada por algumas áreas específicas da empresa não surtem o mesmo efeito.

Por fim, existe a necessidade de se manter uma disciplina e constância na aplicação das práticas consideradas, visando à melhoria contínua dos processos. Foram verificados exemplos de aplicações de práticas enxutas que ocorreram no passado mas que, por alguma dificuldade, acabaram sendo abandonadas, como foi o caso do SBCE na Empresa C.

Com a superação de tais barreiras, espera-se que as empresas de RDU possam ter maior sucesso na aplicação de práticas enxutas. Conforme mencionado na Seção 1.1, os principais beneficiados por soluções que melhoram a produtividade são ao final os próprios consumidores - que passam a receber os serviços com mais qualidade e rapidez de atendimento a um menor custo - e, principalmente, a população ainda não atendida pelos serviços, para os quais a diminuição do custo tende a facilitar o acesso à utilidade desejada e seu consumo.

. É importante ressaltar que a implementação de cada prática de modo isolado e local pode até ser bem sucedida e benéfica para a produtividade, mas não surte 0 mesmo efeito que uma ampla iniciativa de desenvolvimento de um sistema de produção enxuta que integre a aplicação das práticas enxutas no âmbito corporativo. 
Vale ressaltar, também, que as empresas de RDU têm algumas vantagens sobre as empresas de outros setores na implementação de um sistema de produção enxuta.

A primeira delas é que as equipes têm um nível de qualificação significativo para trabalhar com relativa autonomia, tanto no processo de construção quanto no de manutenção, visto que a própria natureza dos trabalhos em campo já inviabiliza a presença de um supervisor permanente durante todo o tempo de execução das atividades. Isso facilita a implantação de algumas das práticas enxutas abordadas nesta dissertação, como as do subconjunto de Envolvimento.

A segunda vantagem diz respeito ao fato de na fase em que ocorre a distribuição, ou seja, a partir do momento em que o cliente é ligado, as características da RDU se assemelharem às da indústria de processo contínuo. Conforme visto na Seção 3.4.2, nesse tipo de indústria, o fluxo já está préestabelecido, representado pelo próprio fluxo físico do material através dos equipamentos. Sendo assim, a abordagem em relação aos desperdícios das utilidades distribuídas pode ser simplificada.

De forma geral, pode-se afirmar que a pesquisa cumpriu com o objetivo exposto na Seção 1.2, embora seja necessário mencionar algumas limitações. Em primeiro, foram desenvolvidos apenas três estudos de caso, sendo apenas um em cada tipo de RDU e todas na mesma região geográfica. Em segundo, foram entrevistados apenas dois gestores em cada caso, sendo um do processo de construção e outro do processo de manutenção, não sendo possível assegurar que houve absoluta isenção de opinião nas respostas dos entrevistados. Em terceiro, não foi possível realizar visitas para observar a execução das atividades de campo e assim extrair dados adicionais para a análise.

Além de cumprir com o objetivo exposto na Seção 1.2, esta pesquisa gerou outros resultados secundários, descritos a seguir:

- As Seções 2.1 e 2.2 formalizam a conceituação de Redes de Distribuição de Utilidades (RDUs), explicando como as mesmas se posicionam entre os setores de serviços e nas cadeias de fornecimento das quais fazem parte. 
- A Seção 2.3 fornece uma forma de entender o processo produtivo típico de uma RDU, por meio da análise de seu valor sob o ponto de vista do cliente e da cadeia de valor necessária para fornecê-lo.

- A Seção 3.5 organiza e propõe um conjunto de práticas enxutas que foi adotado como base para esta pesquisa, mas que pode ser aproveitado para embasar outras pesquisas que tratem de setores semelhantes às RDU, como telefonia, ferrovia, televisão a cabo, etc.

- Com base nas análises do Grau de Relação GR apresentadas ao longo das descrições dos casos no Capítulo 5, observa-se que há uma maior tendência de aplicação das práticas de produção enxuta para procurar atingir objetivos de custo e de lead time que objetivos de qualidade, o que corrobora afirmações de autores como George (2004), Bendell (2005) e Arnheiter e Maleyeff (2005) mencionadas na Seção 3.5.

Para trabalhos futuros, são sugeridos os seguintes temas, complementares ao desta dissertação:

- Expansão da abrangência geográfica do estudo, de forma a incluir diversas empresas de cada tipo de RDU, podendo-se inclusive partir para uma pesquisa do tipo survey (conforme o número de empresas estudadas).

- Desenvolvimento de um projeto de implementação e aplicação das práticas enxutas em campo, por meio da condução de pesquisa-ação com análise temporal numa empresa de RDU;

- Realização de estudos sobre outros processos da RDU que não foram incluídos no escopo desta dissertação, tais como medição e faturamento, atendimento ao cliente, ligação do cliente e manutenção corretiva da rede (ver Seção 2.3.2).

- Estudo comparativo mais detalhado entre os padrões de aplicação de práticas enxutas em processos de RDU e de outros setores como telefonia, ferrovia, construção civil e a indústrias de processo contínuo, entre os quais há similaridades. 
- Estudo da relação entre a natureza do controle da empresa - pública ou privada - e sua disposição para assimilação do pensamento enxuto e da produção enxuta. 


\section{Referências bibliográficas}

ABDULLAH, F. Lean Manufacturing tools and techniques in the process industry with a focus on steel. Tese (Doutorado). Graduate Faculty of School of Engineering, University of Pittsburgh, 2003.

ABDULMALEK, F. A.; RAJGOPAL, J.; NEEDY, K. L. A Classification Scheme for the Process Industry to Guide the Implementation of Lean. Engineering Management Journal, v. 18, n. 2, p. 15-25, 2006.

ANDERSON, G. L. 'Do frogs jump as a result of privatisation? Impact of privatisation on buyer-supplier relationships. European Journal of Purchasing and Supply Management, v. 7, n. 1, p. 1-13, 2001.

ARBÓS, L. C. Design of a Rapid Response and high efficient service by lean production principles: Methodology and evaluation of variability of performance. International Journal of Production Economics, v. 80, p. 169-183, 2002.

ARNHEITER, E. D.; MALEYEFF, J. The integration of lean management and Six Sigma. The TQM Magazine, v. 17, n. 1, p. 5-18, 2005.

ASHAYERI, J.; TELLEN, A.; SELEN, W. Computer-integrated manufacturing in the chemical industry. Production and Inventory Management Journal, v. 37, n. 1 , p. 52-57, 1996.

BALLARD, G. The Last Planner. Northern California Construction Institute, Monterey, CA, April 22-24, 1994. Disponível em: $<$ http://www.leanconstruction.org/pdf/LastPlanner.pdf>. Acesso em: 01/09/2008.

BALLARD, G.; HOWELL, G. Shielding Production: Essential Step in Production Control. Journal of Construction Engineering and Management, v. 124, n. 1, p. 11-17, 1998.

BALLARD, H. G. The Last Planner System of Production Control. Tese (Doutorado) - School of Civil Engineering, Faculty of Engineering, The University of Birminghham, Birmingham, 2000.

BALLÉ, F.; BALLÉ, M. A mina de ouro: uma transformação lean em romance. São Paulo: Bookman, 2006. 
BAMBER, C. J. et al. Cross-functional team working for overall equipment effectiveness (OEE). Journal of Quality in Maintenance Engineering, v. 9, n. 3, p. 223-238, 2003.

BAMBER, C. J.; SHARP, J. M; HIDES, M. T. Factors affecting successful implementation of total productive maintenance. Journal of Quality in Maintenance Engineering, v. 5, n. 3, p. 162-181, 1999.

BEESLEY, M. E. Privatization, Regulation and Deregulation. Routledge, 1992.

BENBASAT, I.; GOLDSTEIN, D. K.; MEAD, M. The Case Research Strategy in Studies of Information Systems. MIS Quarterly / September 1987, p. 369-386, 1987.

BENDELL, T. Structuring business process improvement methodologies. Total Quality Management \& Business Excellence, v. 16, n. 8, p. 969-978, 2005.

BERNSTEIN, J. I.; SAPPINGTON, D. E. M. Setting the X-Factor in Price-Cap Regulation Plans. Journal of Regulatory Economics, v. 16, p. 5-25, 1999.

BERTELSEN, S. Construction as a Complex System. In: ANNUAL CONFERENCE OF THE INTERNATIONAL GROUP FOR LEAN CONSTRUCTION, 11, julho de 2003, Virginia, EUA. Proceedings... Virginia: IGLC, 2003.

BERTELSEN, S. et al. Construction Physics. In: ANNUAL CONFERENCE OF THE INTERNATIONAL GROUP FOR LEAN CONSTRUCTION, 15, julho de 2007, Michigan, EUA. Proceedings... Michigan: IGLC, 2007. p. 13-26.

BERTELSEN, S.; KOSKELA, L. Construction Beyond Lean: Understanding of Construction Management. In: ANNUAL CONFERENCE OF THE INTERNATIONAL GROUP FOR LEAN CONSTRUCTION, 12, 2004, Elsinore, Dinamarca, 2004. Proceedings... Elsinore: IGLC, 2004.

BERTELSEN, S.; SACKS, R. Towards a new understanding of the construction industry and the nature of its production. In: ANNUAL CONFERENCE OF THE INTERNATIONAL GROUP FOR LEAN CONSTRUCTION, 15, julho de 2007, Michigan, EUA. Proceedings... Michigan: IGLC, 2007. p. 46-56.

BERTELSEN, S.; SACKS, R. Bridging the Gaps - Towards a Comprehensive Understanding of Lean Construction. In: ANNUAL CONFERENCE OF THE INTERNATIONAL GROUP FOR LEAN CONSTRUCTION, 10, Agosto de 2002, Gramado, Brasil. Proceedings... Gramado: IGCL, 2002. 
BILLESBACH, T. J. Applying lean production principles to a process facility. Production and Inventory Management Journal, v. 35, n. 3, p. 40-44, 1994.

BONOMA, T. V.; Case Research in Marketing: Opportunities, Problems, and a Process. Journal of Marketing Research, v. 22, n. 2, p. 199-208, 2005.

BOWEN, J.; FORD, R. C. Managing Service Organizations: Does having a "thing" make a difference? Journal of Management, v. 28, n. 3, p. 447-469, 2002.

BRANSTON, J. R. A counterfactual price analysis of British electricity privatisation. Utilities Policy, v. 9, n. 1, 2000.

BRASIL. Agência Nacional de Energia Elétrica (ANEEL). Superintendência de Regulação Econômica. Audiência Pública AP 023/2002. Nota Técnica № 326/2002/SRE/ANEEL. Cálculo do Fator X na Revisão Tarifária Periódica das Concessionárias de Distribuição de Energia Elétrica. 25 de outubro de 2002. Disponível em: <http://www.aneel.gov.br/aplicacoes/Audiencia_Publica/audiencia_proton/2002/ap02 3/NT_FX_29out02.pdf>, acesso em 23/01/2008.

BRASIL. Ministério das Cidades. Secretaria Nacional de Saneamento Ambiental. Sistema Nacional de Informações sobre Saneamento, Versão 4.0, maio de 2006. Disponível em: <http://www.snis.gov.br>. Acesso em: 31/12/2007.

BRASIL. Ministério de Minas e Energia. Plano Nacional de Energia 2003 / Ministério de Minas e Energia. Brasília: MME: EPE, 2007.

CARRIJO, J. R. S.; LIMA, C. R. C. Disseminação TPM - Manutenção Produtiva Total nas indústrias brasileiras e no mundo: uma abordagem construtiva. In: ENCONTRO NACIONAL DE ENGENHARIA DE PRODUÇÃO, XXVIII, 2008, Rio de Janeiro, RJ. Anais... Rio de Janeiro: ABEPRO, 2008.

CHEN, Q.; REICHARD, G.; BELIVEAU, Y. An interface object model for interface management in building construction. In: EWork and EBusiness in Architecture, Engineering and Construction: 6th European Conference on Product and Process Modelling, 13-15 September 2006, Valencia, Spain. Proceedings... Valencia: Taylor \& Francis, 2006.

CHEN, Q.; REICHARD, G.; BELIVEAU, Y. Interface Management - a Facilitator of Lean Construction and Agile Project Management. In: ANNUAL CONFERENCE OF THE INTERNATIONAL GROUP FOR LEAN CONSTRUCTION, 15, julho de 2007, Michigan, EUA. Proceedings... Michigan: IGLC, 2007. p. 57-66. 
CHOO, H. J.; TOMMELEIN, I. D. Requirements and barriers to adoption of Last Planner Computer Tools. In: ANNUAL CONFERENCE OF THE INTERNATIONAL GROUP FOR LEAN CONSTRUCTION, 9, julho de 2001, Cingapura. Proceedings... Cingapura: IGCL, 2001.

CINGAPURA. Singapore Department of Statistics. Gross Domestic Product by Industry at 2000 Prices, Seasonly Adjusted (Table A1.2). In: Economic Survey of Singapure Third Quarter 2007. Disponível em http://www.singstat.gov.sg/stats/themes/economy/ess/essa12.pdf, acesso em 24/12/2007.

COOK, R. L.; ROGOWSKI, R. A. Applying JIT principles to continuous process manufacturing supply chains. Production and Inventory Management Journal, v. 37, n. 1, p. 12-17, 1996.

COSTA, A. C. F.; JUNGLES, A. E.; OLIVEIRA, R. R. Diretrizes para o Desenvolvimento da Comunicação no Gerenciamento de Projetos: uma Abordagem da Teoria da Ação como Perspectiva da Linguagem. In: ENCONTRO DE TECNOLOGIA DE INFORMAÇÃO E COMUNICAÇÃO NA CONSTRUÇÃO CIVIL, III, 11 e 12 de julho de 2007, Porto Alegre, RS. Anais... Porto Alegre: ANTAC (Associação Nacional de Tecnologia do Ambiente Construído), 2007.

COUGHLAN, P.; COGHLAN, D. Action Research for Operations Management. International Journal of Production \& Operations Management, v. 22, n. 2, p. 220-240, 2002.

CRAMA, Y.; POCHET, Y.; WERA, Y. A discussion of production planning approaches in the process industry. CORE Discussion Paper 2001/42. Louvain-laNeuve, Bélgica: Université Catholique de Louvain, Center for Operations Research and Econometrics, 2001.

DANIELETTO, J. R. B. Manual de tubulações de polietileno e polipropileno: característica, dimensionamento e instalação. São Paulo: Ed. Linha Aberta, 2007.

DENNIS, D. R.; MEREDITH, J. R. An analysis of process industry production and inventory management systems. Journal of Operations Management, v. 18, n. 6, p. 683-699, 2000.

DENNIS, P. Produção Lean Simplificada: Um guia para entender o sistema de produção mais poderoso do mundo. Tradução de Rosalia Angelita Neumann Garcia. Porto Alegre: Bookman, 2008. 
DIMOCK, M. E. British Utilities and National Development. London: George Allen \& Unwin Ltd., 1933.

ELIAS, S. J. B.; MAGALHÃES, L. C. Contribuição da Produção Enxuta para obtenção da Produção mais Limpa. In: ENCONTRO NACIONAL DE ENGENHARIA DE PRODUÇÃO, XXIII, 2003, Ouro Preto, MG. Anais... Ouro Preto: ABEPRO, 2003.

EMILIANI, M. L. Lean behaviors. Management Decision, v. 36, n. 9, p. 615-631, 1998.

ESTACHE, A.; ROSSI, M. A. How different is the efficiency of public and private water companies in Asia? The World Bank Economic Review, v. 16, n. 1, p. 139148, 2002.

FARIA, R. C.; SOUZA, G. S.; MOREIRA, T. B. Public Versus Private Water Utilities: Empirical Evidence for Brazilian Companies. Economics Bulletin, v. 8, n. 2, 2005.

FORD, H. Today and Tomorrow. Graden City, NY: Doubleday, Page \& Company, 1926. Reprint Edition. Portland, OR: Productivity Press, 1988.

FORZA, C. Survey Research in Operations: a process-based perspective. International Journal of Production \& Operations Management, v. 22, n. 2, p. 152194, 2002.

FRANSOO, J. C.; RUTTEN, W. G. M. M. A Typology of Production Control Situations in Process Industries. International Journal of Operations \& Production Management, v. 14, n. 12, p. 47-57, 1994.

GALSWORTH, G. D. Visual Systems: Harnessing the Power of a Visual Workplace. Amacom, 2006.

GEORGE, M. L. Lean Seis Sigma para Serviços: Como Utilizar Velocidade Lean e Qualidade Seis Sigma para Melhorar Serviços e Transações. Rio de Janeiro: Qualitymark, 2004.

GÓMEZ-IBÁÑEZ, J. A. Regulating Infrastructure: Monopoly, Contracts, and Discretion. Estados Unidos: Harvard University Press, 2006.

GROSFELD-NIR, A.; RONEN, B. The complete Kit: modelling the managerial approach. Computers and Industrial Engineering, v. 34, n. 3, p. 695-701, 1998. 
GUMMESSON, E. Productivity, quality and relationship marketing in service operations. International Journal of Contemporary Hospitality Management, Volume 10, Issue 1, 1998.

HA, S. Continuous Processes can be Lean. Manufacturing Engineering, v. 138, n. 6, p. 103-109, 2007.

HARTMANN, E. H. Successfully installing TPM in a Non-Japanese Plant. Pittsburg: TPM Press, 1992.

HASSANEIN, A. A. G.; KHALIFA, R. A. Financial and operational performance indicators applied to public and private water and wastewater utilities. Engineering, Construction and Architectural Management, v. 14, n. 5, p. 479-492, 2007.

HIRANO, H. 5 Pillars for the Visual Workplace: The Sourcebook for $5 \mathrm{~S}$ Implementation. Productivity Press: New York, 1995.

HJALMARSSON, L.; VEIDERPASS, A.; Productivity in Swedish Electricity Retail Distribution. The Scandinavian Journal of Economics, v. 94, Supplement.p. 193205, 2002.

HOPP, W. J.; SPEARMAN, M. L. Factory Physics: Foundations of Manufacturing Management. 2nd Ed. New York: McGraw-Hill, 2001.

HROVATIN, N.; ZORIC, J.; SCARSI, J. C.; PARIPOVIC, M.; SENCAR, M. The relative performance of electricity distribution utilities from Slovenia, the Netherlands and the UK: an application of data envelopment analysis. Economic Business Review, v. 7, n. 4, p. 329-349, 2005.

INTERNATIONAL ORGANIZATION FOR STANDARDIZATION. ISO 9001:2008: Quality Management Systems - Requirements. Genebra, 2008.

IP, W. H.; LEE, K. C.; YUNG, K. L.; YAM, R. SCADA in an integrated maintenance management system. Journal of Quality in Maintenance Engineering, Vol. 6 No. 1, 2000, pp. 6-19.

JACOB, N. A.; SIOSHANSI, F. P. Transforming Traditional Utilities in the New World of Competition. The Electricity Journal, v. 15, n. 1, p. 84-91, 2002.

JOHNSTON, R.; JONES, P. Service Productivity - Towards understanding the relationship betweeen operational and customer productivity. International Journal of Productivity and Performance Management, v. 53, n. 3, p. 201-213, 2004. 
JONES, E.; BIGHAM, T. C. Principles of Public Utilities. New York: Macmillan Company, 1937.

KARIUKI, M.; SCHWARTZ, J. Small-Scale Private Service Providers of Water Supply and Electricity: A Review of Incidence, Structure, Pricing and Operating Characteristics. World Bank Policy Research Working Paper 3727. World Bank, 2005.

KESSIDES, I. N. Infrastructure Privatization and Regulation: Promises and Perils. The World Bank Research Observer, v. 20, n. 1, p. 81-108, 2005.

KINNIE, N.; HUTCHINSON, S.; PURCELL, J. Downsizing: is it always lean and mean? Personnel Review, v. 27, n. 4, p. 296-311, 1998.

KOBE, K. The Small Business Share of GDP, 1998-2004. Small Business Research Summary, n. 299, Office of Advocacy, United States Small Business Administration, 2007. Disponível em www.sba.gov/advo/research/rs299tot.pdf. Acesso em 11/12/2007.

KOSKELA, L. An exploration towards a production theory and its application to construction. Tese (Doutorado) - Helsinki University of Technology, Espoo, Finlândia, 2000.

KOSKELA, L. Application of the new production philosophy to construction. Stanford University, Center for Integrated Facility Engineering, Thecnical Report Number 72. Standford: Standford University, 1992.

KOSKELA, L. Making-Do - The Eight Category of Wate. In: ANNUAL CONFERENCE OF THE INTERNATIONAL GROUP FOR LEAN CONSTRUCTION, 12, 2004, Copenhagen, Dinamarca. Proceedings... Copenhagen: IGLC, 2004.

KOSKELA, L. Management of Production in Construction: A Theoretical View. In: ANNUAL CONFERENCE OF THE INTERNATIONAL GROUP FOR LEAN CONSTRUCTION, 7, 1999, Berkeley, Califórnia, EUA. Proceedings... Berkeley: IGCL, 1999. p. 241-252.

KRINGS, D.; LEVINE, D.; WALL, T. The Use of "Lean" in Local Government. PM. Public Management, v. 88, n. 8, p. 12-17, 2006.

KUTSCHER, R. E.; MARK, J. A. The service producing sector: some common perceptions reviewed. Monthly Labor Review. April, 2003. 
KVALE, S. Interviews: An Introduction to Qualitative Research Interviewing. Sage Publications Inc, 1996.

LEÃO, R. GTD - Geração, Transmissão e Distribuição de Energia Elétrica. Fortaleza: Universidade Federal do Ceará, 2008. Resultado de uma coletânea de notas de aula em atendimento à disciplina de Geração, Transmissão e Distribuição de Energia Elétrica - GTD, do curso de graduação em Engenharia Elétrica da Universidade Federal do Ceará.

LEE, J. D.; OH, K. J.; KIM, T.Y. Productivity growth, capacitiy utilization, and technological progress in the natural gas industry. Utilities Policy, v. 8, n. 2, p. 109$119,1999$.

LEI (LEAN ENTERPRISE INSTITUTE). Léxico Lean: Glossário ilustrado para praticantes do pensamento Lean. Edição de Chet Marchwinski e John Shook. Tradução de Adriana C. C. Maciel. São Paulo: Lean Institute Brasil, 2003.

LEXECON. Understanding the Natural Gas Markets. Trabalho desenvolvido pela consultoria Lexecon para o American Petroleum Institute (API). API, 2006. Disponível em: http://www.api.org/aboutoilgas/upload/UNDERSTANDING_NATURAL_GAS_MARKE TS.pdf. Acesso em: 19/02/2009.

LIKER, J. K. O Modelo Toyota - 14 Princípios de Gestão do Maior Fabricante do Mundo. Porto Alegre: Bookman, 2005.

LIKER, J. K.; MEIER, D. O Modelo Toyota: Manual de Aplicação. Porto Alegre: Bookman, 2007.

LOWRY, M. N.; GETACHEW, L.; HOVDE, D. Economic benchmarking of cost performance: the case of U. S. Power Distributors. The Energy Journal, v. 26, n. 3, p. 75-92, 2005.

MACHADO, M. C. Abordagem Enxuta nas Empresas. In: OLIVEIRA, O. J. (Org.). Gestão Empresarial: Sistemas e Ferramentas. São Paulo: Atlas, 2007.

MACOMBER, H.; HOLWELL, G. A. The Great Wastes In Organization. In: ANNUAL CONFERENCE OF THE INTERNATIONAL GROUP FOR LEAN CONSTRUCTION, 12, agosto de 2004, Copenhague, Dinamarca. Proceedings IGLC-12. Copenhague: IGCL, 2004.

MALEYEFF, J. Exploration of internal service systems using lean principles. Management Decision, v. 44, n. 5, p. 674-689, 2006. 
MENEZES, L. C. M. Gestão de Projetos. $2^{2}$ ed. São Paulo: Atlas, 2003.

MEREDITH, J. Building operations management theory through case and field research. Journal of Operations Management, v. 16, p. 441-454, 1998.

MODIANO, E. Um balanço da privatização nos anos 90. In: A Privatização no Brasil - O caso dos serviços de utilidade pública. Brasília: BNDES, 2000.

MOORE, R. Reliability-centered maintenance. In: Selecting the Right Manufacturing Improvement Tools, 2007, p. 221-245. Disponível em: $<$ http://www.sciencedirect.com/science?_ob=MiamilmageURL\&_imagekey=B8K4T$4 \mathrm{PKHF} 13-\mathrm{N}-$

$1 \& \_c d i=44183 \&$ user $=5674931 \&$ _check $=\mathrm{y} \& \_$orig $=$search\&_coverDate $=09 \% 2 \mathrm{~F} 01 \% 2$ F2007\&view=c\&wchp=dGLbVzb-

zSkWW\&md5=f9e691bc5b708b54ae38496a476fc62e\&ie=/sdarticle.pdf>. $\quad$ Acesso em: 04/07/2008.

MOTTA, R. S.; MOREIRA, A. Efficiency and regulation in the sanitation sector in Brazil. Utilities Policy, v. 14, n. 3, p. 185-195, September 2006.

MÜLLER, R. M. Integração do Método SMED ao Custeio ABC no Diagnóstico de Prioridades de Melhoria nas Operações de Setup. 2007. Dissertação (Mestrado). Setor de Tecnologia, Universidade Federal do Paraná, Curitiba, 2007.

NAKAJIMA, S. Introdução ao TPM: Total Productive Maintenance. Tradução de Mario Nishimura. São Paulo: IMC International Sistemas Educativos Ltda., 1989.

NEWBERY, D. M. G. Privatisation and Liberalisation of Network Utilities. European Economic Review, v. 41, n. 3, p. 357-383, 1998.

NEWBERY, D. M. G. Privatization, Restructuring, and Regulation of Network Utilities. 3rd Ed. Estados Unidos: Walras-Pareto Lectures, 2001.

NOBRE, J. A. P.; BARROS NETO, J. P. Análise da aplicação do Last Planner em empreendimento de uma empresa de pequeno porte de Fortaleza. In: ENCONTRO NACIONAL DE ENGENHARIA DE PRODUÇÃO, XXIII, 2003, Ouro Preto, MG. Anais... Ouro Preto: ABEPRO, 2003.

OHNO, T. O Sistema Toyota de Produção: Além da Produção em Larga Escala. Trad. Cristina Schumacher. Porto Alegre: Bookman, 1997. 
PALMEIRA, J. N.; TENÓRIO, F. G. Flexibilização organizacional: aplicação de um modelo de produtividade total. Rio de Janeiro: FGV Editora, 2002.

PARKER, D. Performance, risk and strategy in privatised, regulated industries - The UK's experience. The International Journal of Public Sector Management, v. 16, n. 1, p. 75-100, 2003.

PICCHI, F. A. System View of Lean Cosntruction Application Opportunities. In: ANNUAL CONFERENCE OF THE INTERNATIONAL GROUP FOR LEAN CONSTRUCTION, 9, 2001, Cingapura. Proceedings... Cingapura: IGLC, 2001. p. 113.

POSNER, R. A. Natural monopoly and its regulation. 30th anniversary edition with a new preface by the author. Washington D. C.: Cato Institute, 1999.

PRICE, C. W.; WEYMAN-JONES, T. Malmquist indices of productivity change in the UK gas industry before and after privatization. Applied Economics, v.29, n. 1, p. 29-39, 1996.

PUTTMAN, M. T. Logistics in Process Industries: Is it a Specific Problem? Production and Inventory Management Journal; v. 32, n. 3, p. 61-66, 1991.

RAYMOND, W.G. The public and its utilities. New York: John Wiley \& Sons; London: Chapman \& Hall, 1925.

REICHHART; A.; HOLWEG, M. Lean distribution: concepts, contributions, conflicts. International Journal of Production Research; v. 45, n. 16, p. 3699-3722, 2007.

REILLY, T. Distributors and their value propositions. Industrial Distribution, v. 97, n. 9, p. 23, 2008.

REINO UNIDO. Office for National Statistics. 12.5 Gross Domestic Product by industry groups, current basic prices by country and region. 2005. Disponível em: http://www.statistics.gov.uk/StatBase/Expodata/Spreadsheets/D6049.xls, acesso em 24/12/2007.

RONEN, B. The complete Kit concept. International Journal of Production Research, v. 30, n. 10, p. 2457-2466, 1992.

ROULS, D. Field of Dreams: Mobile workers provide the next oportunity for utility productivity gains. Public Utilities Forthnightly, v. 143, n. 3, p. 39-40, Mar 2005. 
SAE INTERNATIONAL. SAE J4001: Implementation of Lean Operation User Manual. Warrendale, 1999.

SANDERSON, J. Passing value to customers: on the power of regulation in the industrial electricity supply chain. Supply Chain Management: An International Journal, v. 4, n. 4, p. 199-208, 1999.

SAVIC, D.; WALTERS, G.; ASHCROFT, P. G.; ARSCOTT, A. Hydroinformatics technology and maintenance of UK water networks. Journal of Quality in Maintenance Engineering, v. 3, n. 4, p. 289-301, 1997.

SAYER, N. J.; WILLIAMS, B. Lean for Dummies. For Dummies, 2007.

SCHMALENSEE, R. A Note on Economies of Scale and Natural Monopoly in the Distribution of Public Utility Services. The Bell Journal of Economics, v. 9, n. 1, p, 270-276, 1978.

SCHMENNER, R. W. How can Service Businesses Survive and Prosper? Sloan Management Review, Spring v. 27, n. 3, p. 21-32, 1986.

SEKINE, K. One-Piece Flow: Cell Design for Transforming the Production Process. Productivity Press: 1992.

SENA, R. M. Manutenção Produtiva Total na Adaptação Estratégica: um Estudo na Eletronorte de 1996 a 2001. 2002. Dissertação (Mestrado). Programa de PósGraduação em Engenharia de Produção, Universidade Federal de Santa Catarina. Florianópolis, 2002.

SHINGO, S. A study of the Toyota Production System: From na Industrial Engineering Viewpoint. Tradução de Andrew P. Dillon. Productivity Press, 1989.

SHIROSE, K. TPM for Workshop Leaders. Productivity Press, 1992.

SINK; D. S; TUTTLE, T.C. Planning and measurement in your organization of the future. Norcross: Industrial Engineering and Management Press, 1989.

SMART, A. Exploring supply chain opportunities in the UK uitilities sector and the supporting role of eMarketplaces. Supply Chain Management: An International Journal, v. 10, n. 4, p. 264-271, 2005. 
SOBEK II, D. K.; WARD, A. C.; LIKER, J. K. Toyota's Principles of Set Based Concurrent Engineering. Sloan Management Review, v. 40, n. 2, p. 67-83, 1999.

STEWART, P. W.; DEWHURST, J. F. Does Distribution Cost Too Much? A Review of the Costs Involved in Current Marketing Methods and a Program for Improvement: The Factual Findings. Reimpressão da edição de 1939, publicada pela Twentieth Century Fund, New York. Ayer Publishing, 1976.

SUMANTH, D. J. Definitions and basic concepts of productivity. In: Productivity engineering and management. New York: McGraw-Hill, 1984.

SWANK, C. K. The lean service machine. Harvard Business Review, v. 81, n. 10, p. 123-129, Oct 2003.

TANGEN, S. Demystifying productivity and performance. International Journal of Productivity and Performance Management, v. 54, n. 1, p. 34-46, 2005.

TRAJANO, I.; LIMMER, C. V.; LONGO, O. C. Léxico terminológico da produção civil. In: SIMPÓSIO LATINO-AMERICANO DE TERMINOLOGIA, II, 1990, Brasília, DF, 1990. Anais... Brasília: Riterm, 1990. Disponível em: http://www.riterm.net/actes/2simposio/trajano.htm. Acesso em: 21/08/2008.

TSANG, A. H. C. Strategic dimensions of maintenance management. Journal of Quality in Maintenance Engineering, v. 8, n. 1, p. 7-39, 2002.

VILLAS-BÔAS, B. T. Modelagem de um Programa Computacional para o Sistema Last Planner de Planejamento. 2004. Dissertação (Mestrado). Setor de Tecnologia, Universidade Federal do Paraná, Curitiba, 2004.

VOSS, C.; TSIKRIKTSIS, N.; FROHLICH, M. Case research in operations management. International Journal of Operations \& Production Management, v. 22, n. 2, p 195-219, 2002.

WACKER, J. G. A theory of formal conceptual definitions: developing theory-building measurement instruments. Journal of Operations management 22 (2004).

WAEYENBERGH, G.; PINTELON, L. A framework for maintenance concept development. International Journal of Production Economics, v. 77, n. 3, p. 299313, 2002.

WARD, A. et al. The Second Toyota Paradox: How Delaying Decisions Can Make Better Cars Faster. Sloan Management Review, v. 36, n. 3, p. 43-61, Spring 1995. 
WILSON, G. L.; HERRING, J. M.; EUTSLER, R. B. Public Utility Industries. New York \& London: McGraw-Hill Company, 1936.

WOMACK, J. P.; JONES, D. T. Lean Thinking. New York: Simon \& Schutzer, 1996.

WOMACK, J. P; JONES, D. T.; ROOS, D. A máquina que mudou o mundo. 16 ed. Rio de Janeiro: Campus, 1992.

YEOMANS, M.; MILLINGTON, P. Getting Maintenance Into TPM. Manufacturing Engineer, v. 76, n. 4, p. 170-173, 1997.

YIN, R. K. Estudo de caso: Planejamento e Métodos. São Paulo: Bookman, 2005.

YUKSAVAGE, R. E.; FAHIM-NADER, M. Gross domestic product by industry for 1947-86: new estimates based on the North American Industry Classification System. Survey of Current Business, dec. 2005. 